\title{
Afro-Zulians in the Trans-Atlantic World: A Case Study of Jean de Chourio and the Black Venezuelans of the Sur del Lago Maracaibo (1722-1811)
}

Raymond Andrew Keller II
West Virginia University

Follow this and additional works at: https://researchrepository.wvu.edu/etd

\section{Recommended Citation}

Keller, Raymond Andrew II, "Afro-Zulians in the Trans-Atlantic World: A Case Study of Jean de Chourio and the Black Venezuelans of the Sur del Lago Maracaibo (1722--1811)" (2010). Graduate Theses,

Dissertations, and Problem Reports. 4616.

https://researchrepository.wvu.edu/etd/4616

This Dissertation is protected by copyright and/or related rights. It has been brought to you by the The Research Repository @ WVU with permission from the rights-holder(s). You are free to use this Dissertation in any way that is permitted by the copyright and related rights legislation that applies to your use. For other uses you must obtain permission from the rights-holder(s) directly, unless additional rights are indicated by a Creative Commons license in the record and/ or on the work itself. This Dissertation has been accepted for inclusion in WVU Graduate Theses, Dissertations, and Problem Reports collection by an authorized administrator of The Research Repository @ WVU.

For more information, please contact researchrepository@mail.wvu.edu. 
Afro-Zulians in the Trans-Atlantic World:

A Case Study of Jean de Chourio and the

Black Venezuelans of the Sur del Lago Maracaibo (1722-1811)

Raymond Andrew Keller, II

Dissertation submitted to the Eberly College of Arts and Sciences at West Virginia University in partial fulfillment of the requirements for the degree of

Doctor of Philosophy in History

\author{
Robert M. Maxon, Ph.D., Chair \\ Sandra Dixon, Ph.D. \\ James Siekmeier, Ph.D. \\ SilverMoon, Ph.D. \\ Evan Widders, Ph.D.
}

\title{
Department of History
}

\author{
Morgantown, West Virginia \\ 2010
}

Keywords: Jean de Chourio; African Diaspora; Afro-Zulians; Venezuelan History Copyright 2010 Raymond Andrew Keller, II 


\section{ABSTRACT \\ Afro-Zulians in the Trans-Atlantic World: A Case Study of Jean de Chourio and the Black Venezuelans of the Sur del Lago Maracaibo (1722-1811) \\ Raymond Andrew Keller, II}

This di ssertation a ddresses the hi story of a s mall c ommunity of the A frican D iaspora m ostly overlooked: the Afro-Zulians as the descendants of the first blacks brought over to the Sur del Lago $\mathrm{M}$ aracaibo $\mathrm{r}$ egion in $\mathrm{V}$ enezuela $\mathrm{b} y \mathrm{t}$ he $\mathrm{B}$ asque-French $\mathrm{s}$ lave $\mathrm{t}$ rader $\mathrm{J}$ ean de $\mathrm{C}$ hourio in 1722. T he significance of this group in the context of colonial Venezuela from the period of 1722-1811, the year of Venezuelan independence, is hi ghlighted. This dissertation examines perceptions that the A fro-Zulian community has of itself, as well as the perceptions that others have of it both within and outside of Venezuela. The theoretical idea central to this study is that despite attempts by the European colonists and Creole elites to strip away the African identity of the Afro-Zulian peoples (deculturation), the Afro-Zulians have managed to hold on to both their racial integrity and those fundamentals of culture, language and religion that 1 ink them to the Imbangala pe oples of pre-colonial Angola. These fundamentals in varying degrees have been transmitted to, and incorporated into, the larger Afro-Venezuelan and even greater multicultural Venezuelan hi storical a nd s ocial $\mathrm{m}$ atrix through a gradual pr ocess of a cculturation a nd conflation. T his s tudy assists in a ugmenting an unde rstanding o f t his ove rlooked m inority's contributions to $\mathrm{V}$ enezuelan hi story and s ociety. In addition, it will s erve to ge nerate further interest a nd i nvestigation on $\mathrm{t}$ he $\mathrm{p}$ art o f hi storians a nd researchers of the A frican Diaspora throughout the Americas. 


\section{ABOUT THE AUTHOR}

Raymond Andrew Keller, II, was born in Cleveland, Ohio in 1954. He currently serves as an Americorps VISTA (Volunteer in Service to America), attached to Literacy Volunteers, a United Way agency in Monongalia County, West Virginia, where he is developing a program to assist immigrants in the United States obtain citizenship.

He g raduated from B edford $\mathrm{S}$ enior $\mathrm{H}$ igh $\mathrm{S}$ chool in B edford, O hio, in 1972, and w ent on $\mathrm{t}$ o honorably serve in both the United States Navy and United States Army, where he worked as a voice intercept ope rator in the Spanish 1 anguage throughout Latin A merica. H e r eceived an associate degree in business from the University of Maryland in 1977, and his bachelor of arts in world history from the University of Maryland in 1985, bot h degrees while on a ctive duty. In 1989 he successfully completed the Multicultural Education Program at the College of Santa Fe in New Mexico, whence he went on to become the Director of English as a Second Language and Bilingual/Multicultural Education programs for secondary education at the Hilmar Unified School District in the San Joaquin Valley in California from 1990-1995.

Keller was employed by VENUSA (Venezuela-United S tates Academy) in Mérida, Venezuela, in 2001 and 2002 as an ESL instructor and editor of the textbook division. He also was attached to La Universidad Valle del Momboy in Valera, Venezuela, from VENUSA. He returned to the United States in 2002 to accept a scholarship in foreign languages at W est Virginia University, receiving his master's degree in Spanish with an emphasis on Latin American literature in May 2004. He enrolled in the doctoral program in the Department of History in the Fall of 2004, and mostly taught classes on Africana Studies, with some World History and Latin America. He and his wife, Ydalis M. Herrera, make their home in Morgantown, West Virginia.

Eskertzen Dizut

(Basque/Euskara) 


\section{ACKNOWLEDGEMENTS}

This dissertation was motivated by several factors. First, my wife, Ydalis María Herrera Chourio, a nd he $\mathrm{r} f$ amily, or iginate in $\mathrm{t}$ he $\mathrm{S}$ ur de 1 Lago $\mathrm{M}$ aracaibo $\mathrm{r}$ egion. $\mathrm{T}$ herefore, $\mathrm{t}$ his dissertation can be considered as a work of love, revealing for the first time a history of the AfroZulians. S econd, I m ade $\mathrm{m}$ y hom e i n v arious c ountries i n A frica from 1995 -1996, a nd Venezuela f rom $2001-2002$, w hence $\mathrm{m}$ y i nterest i $\mathrm{n} \mathrm{the} \mathrm{w}$ orldwide A frican D iaspora $\mathrm{w}$ as significantly a ugmented. $\mathrm{T}$ his di ssertation a llowed $\mathrm{m}$ e $\mathrm{t} \mathrm{o} \mathrm{c}$ onsolidate $\mathrm{m}$ y obs ervations a nd experiences into a case study of one aspect of the Trans-Atlantic world. Lastly, my experiences as a $\mathrm{g}$ raduate $\mathrm{i}$ nstructor of $\mathrm{A}$ fricana $\mathrm{S}$ tudies an $\mathrm{d}$ Latin $\mathrm{A}$ merican $\mathrm{H}$ istory at $\mathrm{W}$ est $\mathrm{V}$ irginia University permitted me to broaden my perspective on the overall dispersion of African peoples throughout Latin America. The research for my classes paralleled the work being carried out on the dissertation.

For the research conducted in Venezuela, special thanks go to my wife Ydalis and her entire family, but particularly to Cirilo Antúnez P irela of S an José and Deglis A tilano Herrera Chourio of S an Antonio for their help with the sections on J ean de Chourio and S an Benito, without whose kind assistance this w ork would not have been pos sible or completed. A nother thank you goes to the entire staff at the public library in Mérida, Venezuela, for their patience in helping me find and allowing me to hand copy the royal decrees pertaining to Juan de Chourio, as well as other important historical documents of the eighteenth and nineteenth centuries. Also highly appreciated were the contributions made by Roberto "Diken" Carlos López of the AfroAsian Center of the La Universidad de Los Andes (ULA) in Mérida, Dr. Jesús Angel Parra of the La Universidad de Zulia (LUZ) Department of History in Maracaibo and es teemed member of 
the Zulia History Academy, as well as Ricardo Pineda from the editorial staff of the Panorama daily newspaper in Maracaibo.

For the research conducted in the United States, a very special thanks to Patty A. Miller, the Executive Director of the Basque Museum and Cultural Center in Boise, Idaho, for all of the unprecedented kindness and help rendered by her and her entire staff in the summer of 2009, without which Chapter Two on the genealogy, life and heritage of Juan de Chourio would only be but a shadow of what ultimately materialized. Another thank you goes to Patty A. Miller for coordinating t he ve rbal a nd e lectronic $\mathrm{m}$ ail $\mathrm{c}$ ommunications be tween $\mathrm{D}$ r. A lberto $\mathrm{S}$ antana Ezkerra, Director of the Basque Studies Program at Boise State University and me. A thank you is a lso extended to Dr. Ezkerra. T he Department of History of W est V irginia University a lso receives thanks and appreciation for the partial funding of the Idaho trip as w ell as two ot her brief excursions to Venezuela.

On the campus of $\mathrm{W}$ est $\mathrm{V}$ irginia U niversity a hearty thank you goes out t o a ll of the members of my committee: Dr. Sandra Dixon (Afro-Hispanic Culture and Spanish Language); Dr. J ames S iekmeier (Latin A merica); D r. K rystal F razier (African A merican); a nd D r. E van Widders ( Colonial $\mathrm{C}$ aribbean a nd $\mathrm{C}$ ircum-Caribbean); but e specially to $\mathrm{m}$ y di ssertation chairman, Dr. Robert M. Maxon, for his steady encouragement and guidance. He was both my compass and Gibraltar in the midst of sometimes troubled seas. A ppreciation also goes out to former W est Virginia University history professors Dr. John C. Super for direction on r eligion and colonial Latin American topics; Dr. J ason P arker for direction on C aribbean and c ircumCaribbean history; Dr. Stephen Zdatny for direction on French history and language; Dr. Priscilla M. S hilaro f or di rection on $\mathrm{W}$ est a nd $\mathrm{C}$ entral African hi story; and $\mathrm{D}$ r. K atherine BankoleMedina, for providing guidance and structure in the foundation phase of the work. 
Acknowledgements also go to my associates in graduate school: K iva Fall Mahkete of Senegal $\mathrm{f}$ or guidance o $\mathrm{n} \mathrm{W}$ est A frican hi story a nd $\mathrm{r}$ eligion; $\mathrm{D} r$. Godriver $\mathrm{O}$ diambo $\mathrm{f}$ or he $\mathrm{r}$ direction on the intricacies of the doctoral process; Nicholas Githuku and Zoa Williams for their material s upport a nd moral e ncouragement; and D r. M áximo $\mathrm{M}$ artínez of $\mathrm{W}$ est $\mathrm{V}$ irginia University for hi s f riendship a nd c ollaborative e fforts on do cumentary and 1 iterary p rojects related to sundry a spects of the A frican Diaspora in the Caribbean and circum-Caribbean with Black Fénix Productions.

This pi lgrim a lso a cknowledges a nd thanks a ll of the ot her angels e ncountered w hile progressing on my journey to the Academy.

Raymond Andrew Keller, II

September 8, 2010

Morgantown, West Virginia 


\section{Table of Contents}

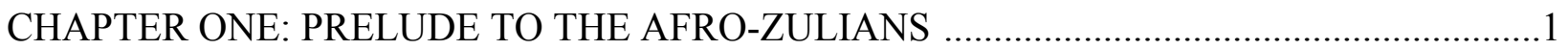

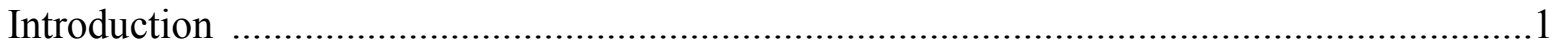

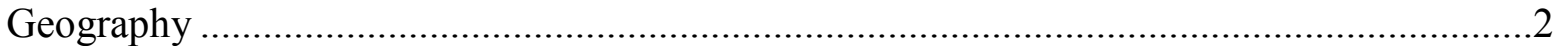

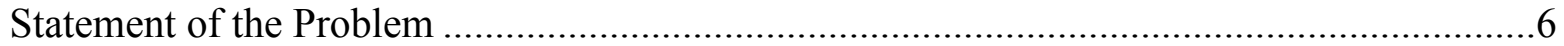

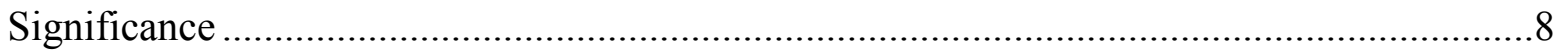

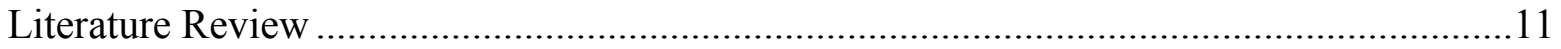

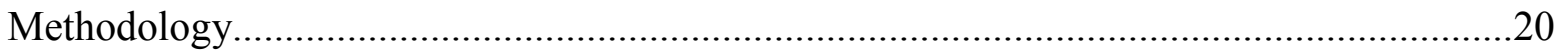

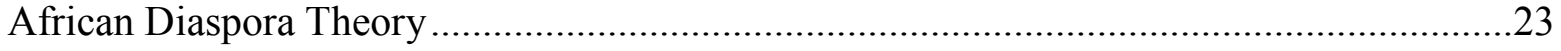

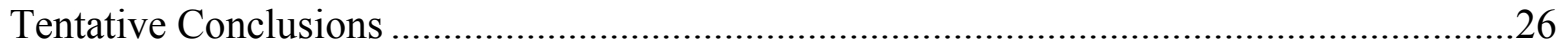

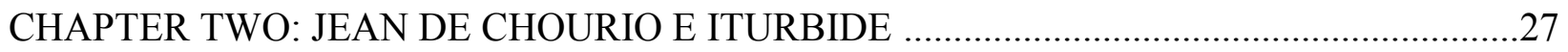

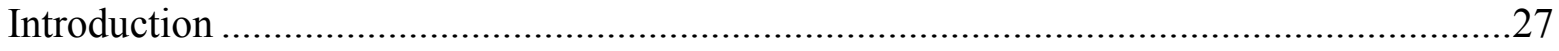

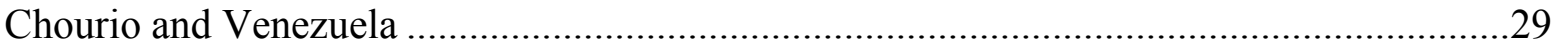

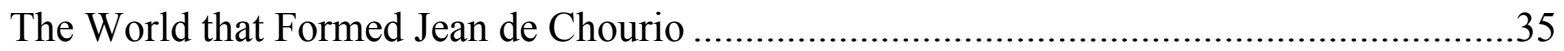

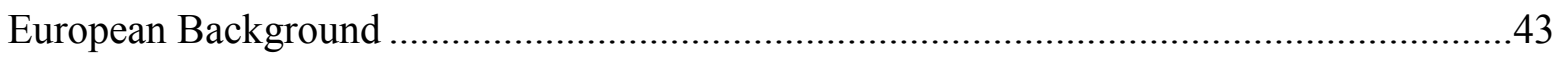

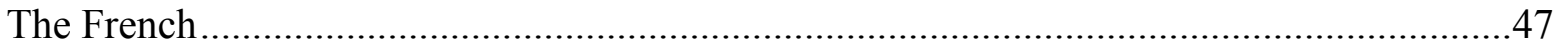

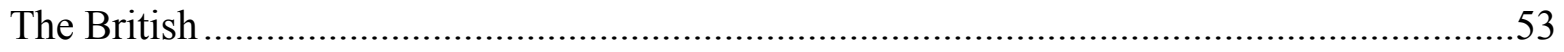

French Attitudes toward Africans Impact Chourio ………...............................................58

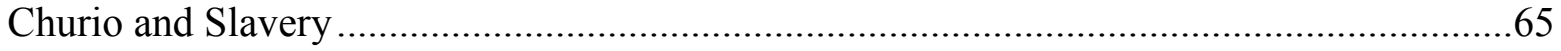

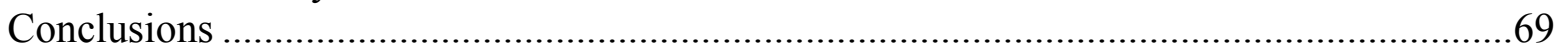

CHAPTER THREE : AFRICAN ROOTS AND EUROPEAN INFLUENCE IN THE SUR DEL

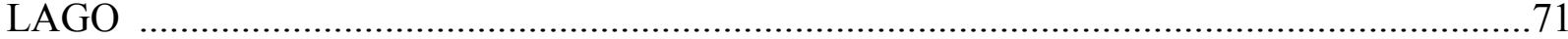

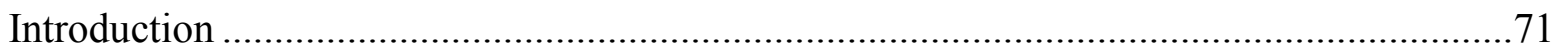

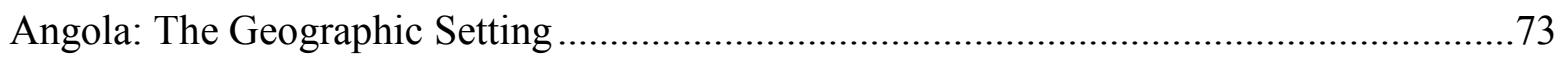

Geography and Political Formation in the Pre-Colonial Era................................................78

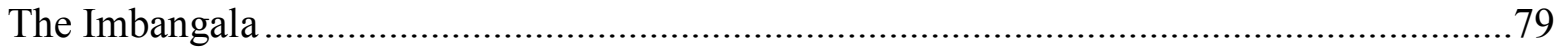

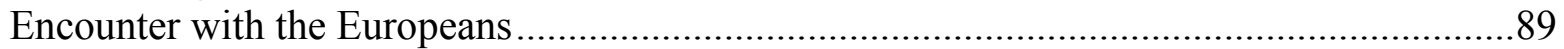

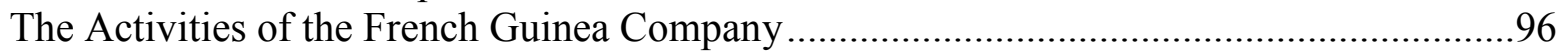

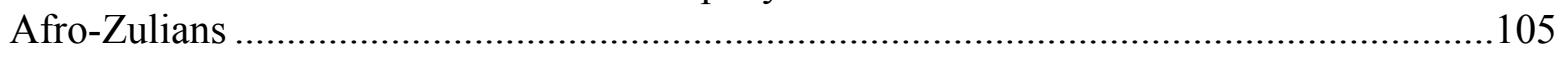

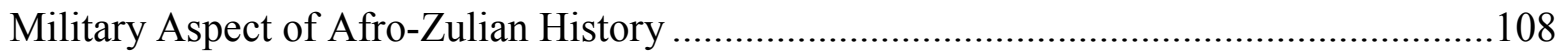

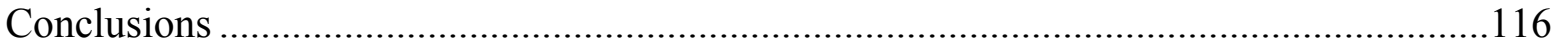

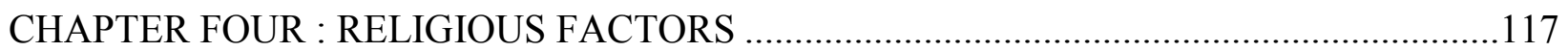

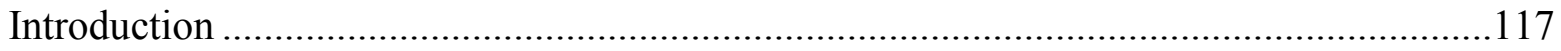

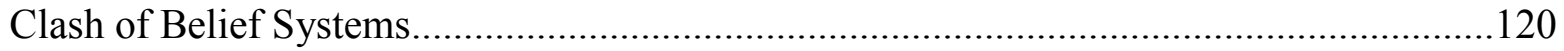

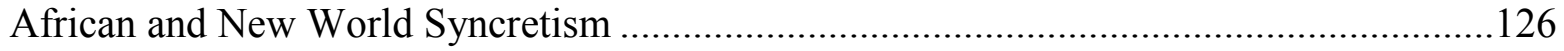

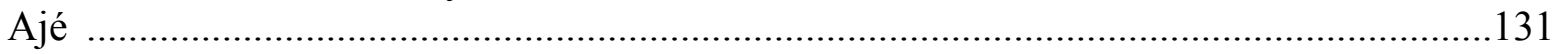

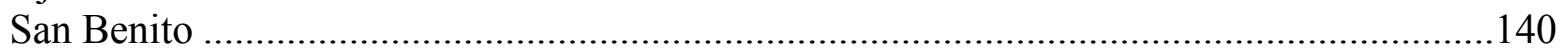

Propagation Efforts of the Capuchin Order..................................................................145

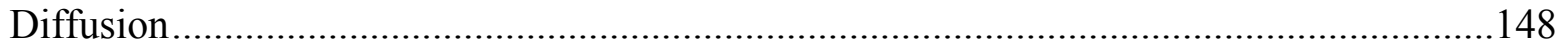

African-European-Indigenous Syncretism ……………………………………....152

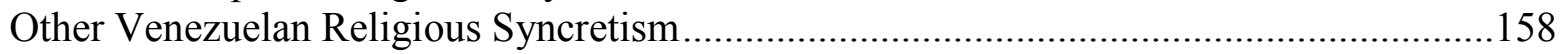

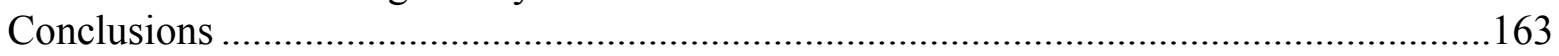




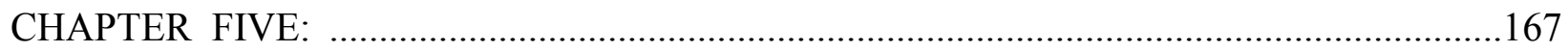

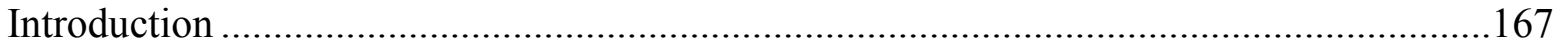

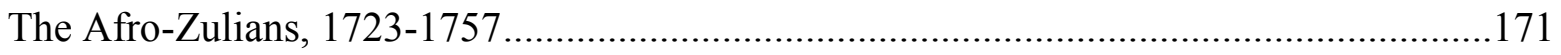

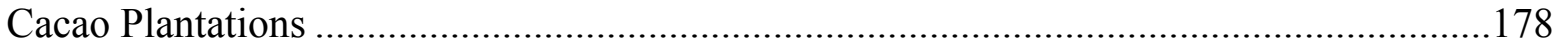

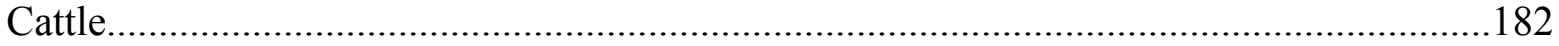

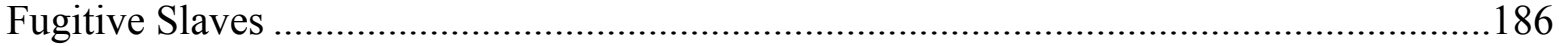

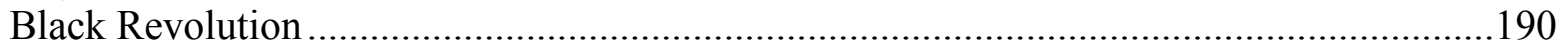

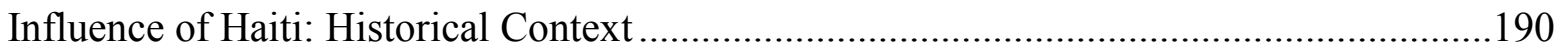

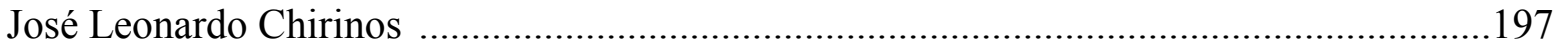

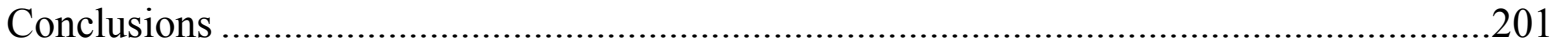

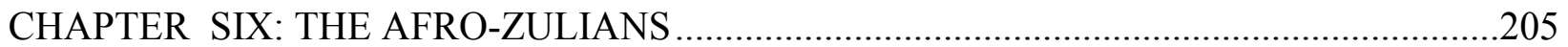

Emergence of an Afro-Zulian Community .....................................................................205

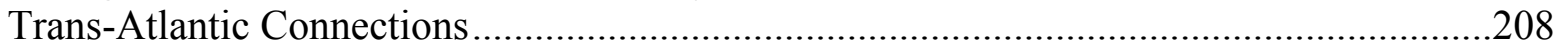

Assimilation of Afro-Zulians in the Venezuelan Nation State ......................................211

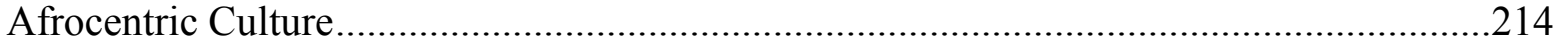

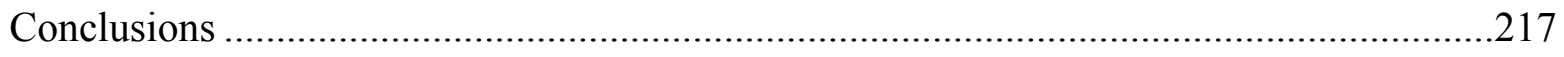

APPENDIX A: CITI Certification/Human Subjects ........................................................219

APPENDIX B: Social Groups by Caste and Race that Formed Spanish Colonial Society in

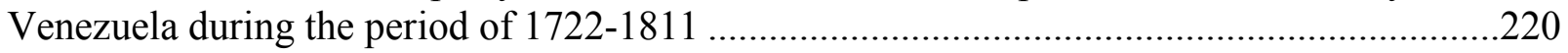

APPENDIX C: Roman Catholic Motivations of Juan de Chourio ..........................................222

APPENDIX D: Map of Venezuelan cumbes, 1550-1800 ...................................................224

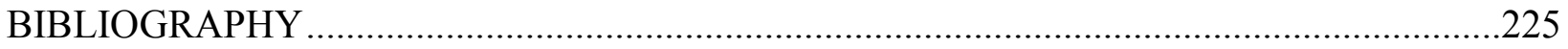




\section{List of Illustrations}

Figure 1.1: Lake Maracaibo in relation to South America and northwest Venezuela....................2

Figure 1.2: Sur del Lago region of Zulia State in relation to the rest of Venezuela .......................3

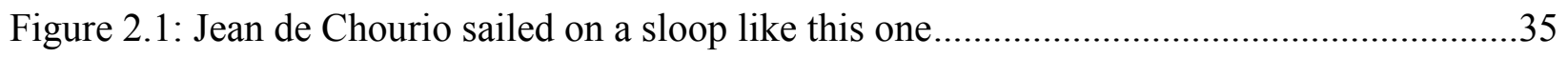

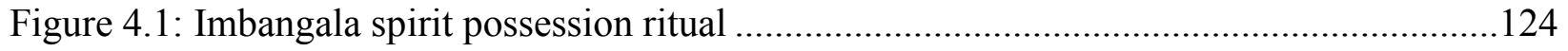

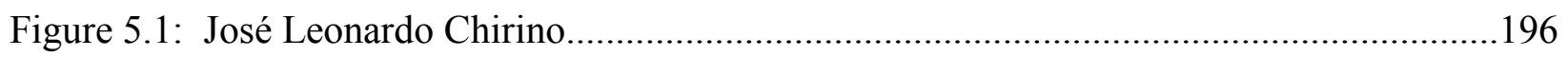

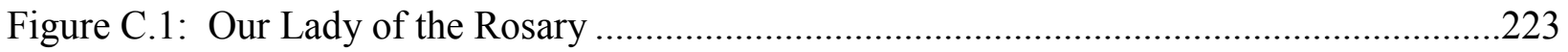




\section{List of Maps}

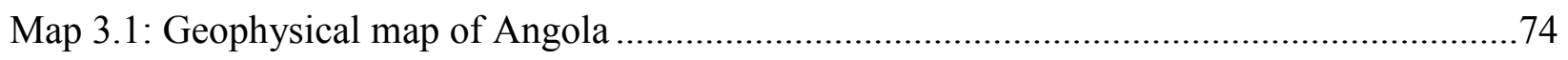

Map 3.2: Contemporary map of Angola depicts major cities and river systems ........................76

Map 3.3: Political map of the contemporary Caribbean and circum-Caribbean ........................99

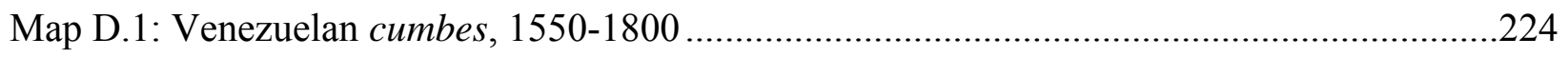




\section{List of Tables}

Table 2.1: Legal Importation of African Slaves in the Spanish American Colonies 


\section{CHAPTER ONE}

\section{PRELUDE TO THE AFRO-ZULIANS}

\section{Introduction}

A review of African Diaspora studies leads the Trans-Atlantic historian to conclude that none of the Afro-American peoples can be understood as isolated local cultures. And in a more expansive sense, none of their involvements in broader relations of $\mathrm{n}$ ational and global pow er relations can fully explain or affix a specific form of ethnogenesis. While linkages to Africa can be ascertained, the task of the researcher into the black peoples of the Sur del Lago, or any other community of the African Diaspora, is one of more than the mere practice of historical recovery, i.e. the collection of data, but rather the application of a critical analysis of meaning from an African centered perspective, what Maulana Karenga refers to as the "Sankofa" principle. 1

Studies conducted on ethnic contingents of the African Diaspora have primarily focused on those a reas of the $\mathrm{W}$ estern $\mathrm{H}$ emisphere with s ignificant d emographic representation. $\mathrm{T}$ his includes those areas where the percentage of blacks in the overall population is high, or where there are large black po pulations in sheer numbers. ${ }^{2}$ Belize, Guyana and sundry islands of the Caribbean have high percentages of black population, while the United States has approximately 36 million blacks, but constituting only thirteen percent of the overall population. ${ }^{3}$ This study addresses a small community of the African Diaspora, the Afro-Zulians, who are the descendants of the first bl acks br ought ove $\mathrm{r}$ t o t he $\mathrm{S}$ ur de 1 Lago $\mathrm{M}$ aracaibo $\mathrm{r}$ egion of $\mathrm{V}$ enezuela b y $\mathrm{t}$ he

\footnotetext{
${ }^{1}$ Maulana Karenga, Introduction to Black Studies (Los Angeles, California: University of Sankore Press, 2002), 7778.

${ }^{2}$ Arlene Torres and Norman E. Whitten, Jr., eds., Blackness in Latin America and the Caribbean: Social Dynamics and Cultural Transformations, 2 vols. (Bloomington: I ndiana U niversity $\mathrm{P}$ ress, 1998). This i s a $\mathrm{n}$ e xtensive compilation of studies dealing with the black populations in individual countries of the Caribbean, Central and South America.

${ }^{3}$ Jesse McKinnon, Black Population of the United States: March 2002 (Washington, DC: U nited States Census Bureau, Current Population Reports, Series P20-541, April 2003), 1. The census is conducted every ten years in the United States.
} 
Basque-French s lave trader J ean de Chourio in the year 1722. T his community is s mall with regard to land occupied, percentage of the national demographic and numbers. ${ }^{4}$ Nevertheless, its significance in the context of colonial Venezuela from the period 1722 through 1811 , the year in which $\mathrm{V}$ enezuelan $\mathrm{i}$ ndependence $\mathrm{f}$ rom $\mathrm{S}$ pain $\mathrm{w}$ as pr oclaimed, $\mathrm{w}$ ill be $\mathrm{t}$ he $\mathrm{f}$ ocus of $\mathrm{t}$ his dissertation. This allows for the sufficient development of those themes pertinent to the AfroZulians a s di aspora pe oples c ognizant of $t$ heir A ngolan or igins, $r$ esistors to e nslavement, opponents of racism, and forgers of their own destiny within the emerging cultural and political Venezuelan mosaic.

\section{Geography}

Figure 1.1: Lake Maracaibo in relation to South America and northwest Venezuela

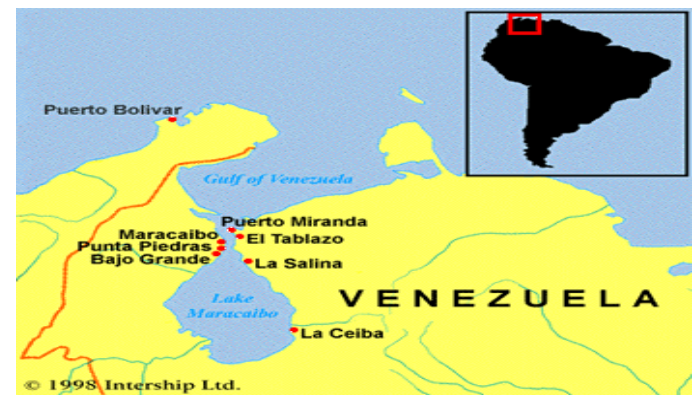

Source: http://www.worldlakes.org/uploads/Maracaibo_index locat.gif

\footnotetext{
${ }^{4}$ Richard A. Haggerty, ed., Venezuela: A Country Study, $4^{\text {th }}$ ed. (Washington, D C: D epartment o f the Army Pamphlet 550-71, 1993), 63. While there has not been an ethnographic census in Venezuela since 1926, it has been estimated that a credible et hnic breakdown would be somewhere around $21 \mathrm{p}$ ercent pure white, 10 percent pure black, 68 percent mestizo and 1 percent indigenous, to include miniscule components of other groups. A nd while the Central Intelligence Agency of the United States concedes that these statistics are generally accurate today, the 21 percentage points for pure whites is probably a little inflated, whereas the mestizo class should reflect a higher number. See Ethnic groups, http://www.cia.gov/cia/publications/factbook/geos/ve.html, 27 September 2002, as well as $\mathrm{M}$ aría $\mathrm{A}$ lenjandra $\mathrm{C}$ arrillo, "En la tierra de los hijos de Ajé," Panorama (daily n ewspaper), $\mathrm{M}$ aracaibo, Venezuela, 16 June 2002. According to Carrillo, with Afro-Zulians constituting a subset of the approximate 2.8 million black Venezuelans, their population in $2002 \mathrm{w}$ as estimated at around 68,400 , mostly concentrated in their ancestral homeland in the $\mathrm{S}$ ucre Municipality, $\mathrm{Zulia}$ state, of the $\mathrm{S}$ ur d el Lago Mar acaibo. This municipality is divided into two sections by a corridor of land that belongs to the neighboring Venezuelan state of Mérida. T he municipality covers 1,174 square kilometers of Zulia state, or approximately $2.33 \%$ of the state's total land area.
} 
Figure 1.2: Sur del Lago region of Zulia State in relation to the rest of Venezuela.

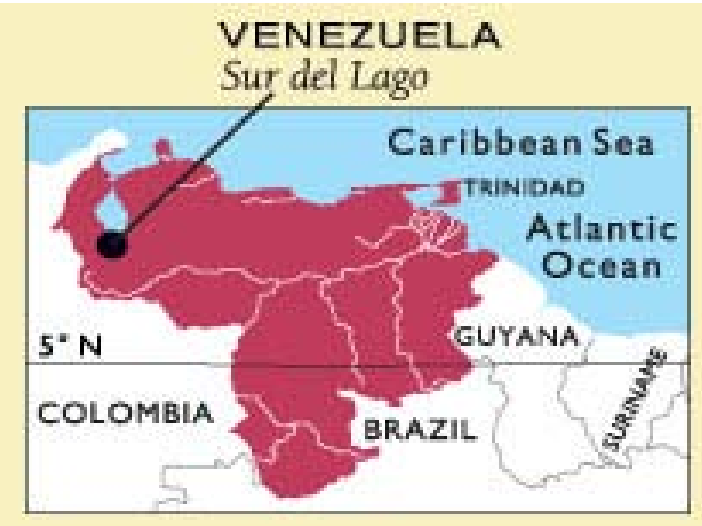

Source: http://www.guittard.com/home/images/growing_regions/surdellago/surdellago02.jp

For the pur pose of c larification, it s hould be noted that $\mathrm{Z}$ ulia is in the extreme nor thwest of Venezuela and that its capital and largest city is Maracaibo (1.5 million inhabitants). The state has a n e stimated popul ation of a bout $3.5 \mathrm{~m}$ illion i nhabitants. I $\mathrm{n}$ a c ontemporary c ontext, the state is i mportant to V enezuela's e conomy be cause of $i$ ts $r$ ich pe troleum de posits. Since the discovery of oi 1 i n Zulia s tate i n 1922, V enezuela ha s be come a n e nergy s uperpower. In cooperation with the state-run oil concern, there are many foreign oil companies operating in the region today. Zulia state is also recognized as the largest producer of milk and associated dairy products in Venezuela, with the majority of these industries being centered in the Sur del Lago region. Zulia state is also one of the principal producers of quality beef cattle. Many Afro- 
Zulians find employment in the oil, dairy and ranching sectors. ${ }^{5}$

Lake Maracaibo is the largest lake in South America. It is approximately 155 kilometers

long and $120 \mathrm{ki}$ lometers wide. On average, it is about $50 \mathrm{~m}$ eters in depth. The lake is fed by

five large rivers: the Catatumbo, the Chama, the Escalante, the Santa Ana and the Zulia, whence

the $\mathrm{s}$ tate de rives $\mathrm{i}$ ts na me. $\mathrm{F}$ or $\mathrm{t}$ he $\mathrm{m}$ ost pa $\mathrm{rt}, \mathrm{t}$ he $\mathrm{g}$ eography and geology ha ve s erved $\mathrm{t} o$ determine the types of towns that have developed a long the lake. A long the eastern shore, oil was the prime m otivator for the growth of pop ulation c enters such as Bachaquero, Cabimas (second 1 argest c ity in Z ulia, 150,000 i nhabitants), Lagunillas, M ene G rande, O jeda, a nd T ia Juana, To the southern and western ends of the lake, we find agricultural and cattle towns, most notably $\mathrm{M}$ achiques i $\mathrm{n}$ the w est a nd $\mathrm{S}$ an $\mathrm{C}$ arlos, $\mathrm{S}$ anta $\mathrm{B}$ arbara a nd o thers $\mathrm{t}$ o $\mathrm{s}$ outh. $\mathrm{T}$ he Venezuelan Andean state of Mérida also lays claim to some of the Sur del Lago, but that will be a matter for the Venezuelan higher courts to arbitrate.

\footnotetext{
5 José Enrique and Gaviria Lievano, "El archipelago de Los Monjes y las relaciones diplomáticas con Venezuela," Revista Credencial Historia 124 (April 2000): 9-15. Larger geo-political issues may impinge upon the future of the Afro-Zulians, such as the so-far diplomatic squabbles regarding an area of the Colombia-Venezuela frontier, i.e. a territorial dispute over the maritime border between both countries in the Gulf of Venezuela, where about 25 miles off the northernmost tip of Colombia lie three current Venezuelan-controlled strategic islands called Los Monjes, which permit entrance to the Gulf of Venezuela, and hence Lake Maracaibo. The gulf is also believed to be rich in oil a nd ga s r eserves. Another i ssue i s t he $\mathrm{r}$ esurgent Zulian i ndependence movement. S ee J ames M inihan, Encylclopedia of the Stateless Nations (Westport, Connecticut: G reenwood Publishing Group, 2002), 21 08-2113. A s mall but in creasingly vocal $\mathrm{n}$ ationalist movement on both sides of the Colombia-Venezuela border s eeks to create an independent Zulian Republic to exert greater control over the natural resources in the area, rather than diverting the acquired wealth, especially from oil revenues, to Bogotá or Caracas. Independence would give Zulians the highest standard of living in Latin America. Some blacks on both sides of the border look favorably on the prospect of Zulian independence. F or information on neighboring Colombia's black population, see Minorities at Risk: Assessment for Blacks in Colombia, http://www.cidcm.umd.edu/mar/assessment.asp?groupId=10001. Colombia's b lack p opulation, lik e $\mathrm{V}$ enezuela's, is distinguished b y e thno-cultural tr aits a nd $\mathrm{r}$ eligious tr aditions combining Catholicism with A frican customs. A fro-Colombians are the descendants of African slaves brought to Colombia in the 1700 s to serve Spanish colonists, primarily as laborers. The abolition of slavery in the years after $1850 \mathrm{c}$ oincided with the di splacement of bl ack laborers b y a $\mathrm{i}$ nflux of n on-blacks s eeking e mployment in the mining, commerce and timber industries then developing in black areas. Consequently, many blacks were forced to look for labor in urban centers, where they work today primarily in domestic service and various low-skilled labor positions. Black labor continues to drive Colombia's labor-intensive industries, notably the coffee plantations, mines and trade services. The long-held practice in both Colombian and Venezuelan society of blanqueamiento, or the disidentification with blackness as expressed through the encouragement of miscegenation and the societal privileging of lighter s kin, carries the legacy of discrimination and disadvantage that $b$ lacks in $b$ oth countries have endured since slavery. About three percent of Colombia's black population inhabits the border area with Venezuela's Zulia State.
} 
Two of the more well-known centers of A fro-Zulian culture in the Sur del Lago are the towns of Bobures (a name of Angolan origin) and Gibraltar (a name of Arabic/Moroccan Berber origin). Bobures is colorful and tropical. Most of its approximately 4,000 inhabitants claim to be descendants of Angolan peoples brought there in colonial times to work the cacao and sugar cane plantations. Bobures is also the terminus of 13 miles of railroad track from an inland sugar refinery. The town has a very clean, sandy beach and is a popular tourist area. As for Gibraltar, it is the hom e of the famous porcelana cacao, w hose be an is w hite when s napped in $t$ wo. Gibraltar became one of the most important transshipping points for the produce of the eastern and nor thern Andean a rea. In the s eventeenth and eighteenth century, the area was not ed for piracy and s muggling a ctivities. $\mathrm{B}$ oth the ma in burro-pack $\mathrm{p}$ ath a nd $\mathrm{train}$ r oute, $\mathrm{c}$ rossing the eastern Andes, found their terminus here. Today there are about 1,000 inhabitants in the town, mostly of African descent. People from all over Venezuela come to both Bobures and Gibraltar from D ecember $27^{\text {th }}$ to $\mathrm{New}$ Y ear's Day in order to listen to s ound of the chimbángueles, or African drums, and honor the black saint, San Benito.

Because of the constant formation of $\mathrm{s}$ and bars further to the nor th in Lake Maracaibo and the need to consistently dredge them, as well as the later development of the oil industry in that sector, trade diminished to a trickle in the Sur del Lago region over time, being diverted to the port city of Maracaibo. A dditionally, the cordillera of the Andes fronting the Sur del Lago inland to the both the east and south, served to further isolate the region. This isolation from the mainstream of the dominant V enezuelan society may have contributed to the perpetuation of a more truly representative Angolan culture in this remote section of Venezuela, where the AfroZulians were able to keep hold of their ethnic integrity more so than blacks in other regions of Venezuela. 


\section{Statement of the Problem}

The pur pose of this dissertation is t o s how how Chourio's g roup w as i nstrumental in halting the process of deculturation ${ }^{6}$ among Afro-Zulians through the infusion, maintenance and fostering of A ngolan Imbangala culture among them. In a ddition, it de tails the emergence of ethnic, linguistic and religious links between the historic Imbangala and the black peoples of the Sur del Lago region of Zulia state that resulted from this process of resisting those forces pushing deculturation. This dissertation also seeks to e stablish those connections that the Afro-Zulians made with the greater Trans-Atlantic world: the Basques, the Dutch, the English, the French, the indigenous $\mathrm{p}$ eoples, $\mathrm{t}$ he $\mathrm{P}$ ortuguese, $\mathrm{t}$ he $\mathrm{S}$ panish, a s w ell a s A fricans and ot hers of A frican descent. This is especially noted in the case of Jean de Chourio, for it is through his exploits that the actions and interactions of the ancestors of the Afro-Zulians with all of these Trans-Atlantic groups, $\mathrm{t}$ o i nclude t he E uropean c olonists a nd $\mathrm{C}$ reole e lites in $\mathrm{t}$ he $\mathrm{C}$ aribbean a nd $\mathrm{C}$ ircumCaribbean regions, are more keenly observed.

In this dissertation, perceptions that Afro-Zulians developed of themselves as a s eparate and di stinct c ommunity a re explored, in a ddition t o the vi ews that ot hers d eveloped of this community bot $\mathrm{h} \mathrm{w}$ ithin a nd out side of $\mathrm{V}$ enezuela. $\mathrm{T}$ hat $\mathrm{m}$ any $\mathrm{A}$ fro-Zulians now $\mathrm{c}$ onsider themselves as members of a co mmunity of $\mathrm{N}$ ew Africa is la rgely the result of th ose $\mathrm{h}$ istoric forces that w orked against the ever present push for deculturation on the part of the European

\footnotetext{
${ }^{6}$ Carlos E steban D eive, "African I nfluence in D ominican C ulture," in Dominican Cultures: The Making of a Caribbean Society, ed. Bernardo Vega (Princeton: Marcus Wiener, 2007), 90, originally published in the Spanish language in 1981 by the Fundación Cultural Dominicana, Santo Domingo, Dominican Republic. In Venezuela, as well as other colonies in the Caribbean and circum-Caribbean regions, the plantation economy absorbed the largest number of s laves. $\mathrm{T}$ his a llowed for $\mathrm{t}$ he e mergence of various $\mathrm{c}$ omplex $\mathrm{c}$ ultural mechanisms, with $\mathrm{t}$ he most prominent being that of "deculturation." In the context of this work, deculturation is defined as a "conscious process to eradicate the culture of one human group for the purpose of economic exploitation." Afro-Venezuelans, for the most $\mathrm{p}$ art, ar e s een as $\mathrm{j}$ ust $\mathrm{s}$ uch a $\mathrm{n}$ ex ploited $\mathrm{g}$ roup. They were $\mathrm{u}$ tilized as a $\mathrm{p}$ rimarily unskilled workforce to facilitate the expropriation of Venezuela's bounteous natural riches. Clearly, in the case of most Afro-Venezuelans, the process of deculturation to which they were subjected, wrought dire consequences for the maintenance of their respective African cultures. This dissertation permits the researcher to see how circumstances served to mitigate the impact of deculturation in the Sur del Lago. See footnote 1 in Chapter Six for a d etailed definition of the cultural mechanism of "acculturation/assimilation."
} 
colonists and their descendants. The theoretical idea central to this study is that despite attempts by the European colonialists and $\mathrm{C}$ reole elites to strip a way the African identity of the A froZulian peoples (deculturation), the Afro-Zulians still maintained a significant semblance of those fundamentals, such as culture, ethnicity, language and religion that linked them to the Imbangala peoples of Angola.

During the formative years of 1722 through 1811 , the Afro-Zulians both contributed to, and $\mathrm{i}$ ncorporated $\mathrm{t}$ hemselves $\mathrm{i}$ nto, $\mathrm{t}$ he $\mathrm{l}$ arger $\mathrm{V}$ enezuelan hi storical a nd $\mathrm{s}$ ocial $\mathrm{m}$ atrix (acculturation). If a ssimilation is defined as the process by which many Africans imported to Venezuela b ecame s ocialized to the dom inant European/Spanish c ulture, the colonial "nationstate," so to speak, then a term is needed to denote the process by which this oppressed people were $\mathrm{t}$ ransformed $\mathrm{b}$ y the c olonizers. T herefore, "deculturation" c omes t o $\mathrm{m}$ ind. $\mathrm{H}$ owever, concepts of e thnicity and $r$ ace a re a mbiguous, at be st, and particularly in V enezuelan hi story. For $\mathrm{V}$ enezuela ha s be come a na tion pe opled b y $\mathrm{m}$ any groups from di verse e thnic and $\mathrm{r}$ acial backgrounds, w ith no group e xcept the ne bulously de fined pardos (in s ome c ontexts is us ed interchangeably $\mathrm{w}$ ith th e te rm mestizos) forming a m ajority. A nd this g roup $\mathrm{r}$ epresents an amalgam of diverse infusions over time. T he dissertation demonstrates, by the very nature of their m ission and de ployment, how the c ore A fro-Zulian c ontingent br ought over b y Chourio was able to resist this trend of deculturation. The Afro-Zulians are not seen as passive, colonized people, but rather as agents of their own destiny.

The na ture and de gree of participation in the process of de culturation and a ssimilation varied with sectors of the A fro-Venezuelan popu lations over time. T his dissertation assists in increasing an unde rstanding of this overlooked minority's contributions to V enezuelan history 
and society. It serves to generate further interest and investigation on the part of researchers of the African Diaspora throughout the Americas.

\section{Significance}

The de cision to introduce the Africans who w ere to be come the A fro-Zulians into the Trans-Atlantic world was made by Jean de Chourio, of Basque ${ }^{7}$ and French descent, and the son of the S panish consul in A msterdam. H e also $r$ epresented the French $t$ rading $\mathrm{C}$ ompañía d e Guinea in Cartagena, Colombia. As early as 1708 he arrived on the island of Curaçao from La Guaira, Venezuela, s etting up a n office with a staff of 32 in the port of Willemstad under the pretext of a commission from King Philip V of Spain to pur chase s laves in both Curaçao and Jamaica for subsequent transport to the colonies of the Spanish American mainland. ${ }^{8}$

In 1709, ho wever, the Dutch $\mathrm{W}$ est Indies $\mathrm{C}$ ompany di rectors in A msterdam forbade Chourio or any of his staff to reside on the island and ordered their immediate deportation and the confiscation of their c ommodities, including hum an one s. A s a s tate of $\mathrm{w}$ ar then existed between the Dutch and the French, the directors were concerned that the constant losses of Dutch ships to French privateers a long major trade routes lent credence to the notion that there were probably some French spies among the $150 \mathrm{~F}$ rench residents of Curaçao. However, because of debts incurred with local merchants and a reliable reputation for paying his bills, Governor Beck

\footnotetext{
${ }^{7}$ Robert J. Ferry, Colonial Elite of Early Caracas (Berkeley: University of California Press, 1989), 195. Linkages are made to prominent families of Basque descent in the ranks of the commodities and slave trading Guipuzcoana Company. Of further note, Ferry states that, "From its headquarters in San Sebastián in the Basque province of Guipúzcoa, the Guipuzcoana Company enjoyed exclusive rights to carry cacao from Caracas to Spain. Reflecting the general autonomy of the Basque provinces, which were united with the crown of Castile only through the person of $\mathrm{t}$ he ki ng, $\mathrm{C}$ ompany ships $\mathrm{c}$ ould $\mathrm{l}$ eave $\mathrm{f}$ or $\mathrm{C}$ aracas di rectly $\mathrm{f}$ rom San $\mathrm{S}$ ebastián without pa ying a ny dut $\mathrm{y}$ whatsoever, and, after stopping to pay royal taxes at Cádiz, they could return there to unload." (Ibid., 4) Chourio apparently saw no conflict in ad vancing the interests of ei ther the French or Guipuzcoana co mpanies, when and where it suited him.

${ }^{8}$ Linda M. Rupert, Roots of Our Future (Willemstad: C uracao C hamber of C ommerce, 20 02), on line book, http://books.caribseek.com/Curacao/Commericial_History_of_Curacao/profiles/jean-chourio.shtml, $\quad(10 \mathrm{M}$ arch 2009).
} 
allowed Chourio to continue his operations on the island. ${ }^{9}$ Despite being under a constant cloud of suspicion, ${ }^{10}$ Chourio profited handsomely in the slave trade; but one year after the signing of the Treaty of Utrecht (1713), ${ }^{11}$ whence the transatlantic s lave trade had fallen under control of the $\mathrm{B}$ ritish, $\mathrm{C}$ hourio $\mathrm{left} \mathrm{t}$ he $\mathrm{i}$ sland t o pur sue hi s $\mathrm{t}$ rade i nterests i $\mathrm{n}$ a $\mathrm{m}$ ore $\mathrm{f}$ avorable $\mathrm{s}$ etting (Venezuela), and never returned to Curaçao. The Treaty of Utrecht provided the basis of British claims against Chourio in both the Netherlands Antilles and Venezuela. ${ }^{12}$ Even after his death, British litigations against his estate in Venezuela continued.

Before his departure from Curaçao in 1714, Chourio purchased 350 of the 1200 Africans who were brought to the island on two ships in 1712. And in early 1714, despite the restrictions then imposed by the Treaty of Utrecht, he purchased 511 of the 556 surviving blacks who arrived on the slave ship San Marcos, and placed an advanced order for that ship's entire cargo from its next trip scheduled later in that same year. But because he had to leave the island before the last contract c ould be fulfilled, e conomic ne cessity impelled Chourio to c ontinue his trafficking in slaves operating from the Spanish American mainland, and that is where a boatload of 600 slaves of Angolan descent arrived intact in the area that is now Zulia state in Venezuela, in 1722.

The involvement of Chourio in the s lave trade was primarily ba sed on economic s elfinterest. However, Chourio's importation of Angolans to Venezuela in 1722 also had a military rationale. In that year, King Philip V of Spain appointed Chourio to serve as a district captain, giving him license to import Africans, found a peaceful town and settle its surrounding area, and

\footnotetext{
${ }^{9}$ C. A. Goslinga, Los Holandeses en Venezuela (Caracas: Asociación Holandesa de Venezuela, 1992), 180.

${ }^{10}$ Ramon.Aizpurua, Curaçao y la costa de Caracas: Introducción al estudio del contrabando de la provincial de Venezuela en tiempos de la compañía Guipouzcoana, 1730-1788 (Caracas: Biblioteca de la Academia Nacional de la Historia, Fuentes para la Historia Colonial de Venezuela \#222, 1993), 323.

${ }^{11}$ Dale M iquelon, "Envisioning the F rench E mpire: U trecht, 1711-1713," French Historical Studies 24:4 (Fall 2001): 653-677.

${ }^{12}$ Francisco de Ugarte to Jose Solis Folch de Cardona, 28 November 1757, Archivo Histórico Nacional de Colombia (Ciudades de Venezuela), Catálogo R-3:110-113, Public Library, Mérida, Venezuela.

Disputations to ok place in Maracaibo o ver the disposition of his property and slaves, contesting the last will and testament of Juan de Chourio.
} 
granted him the authority to pacify the indigenous Motilones, who were then obstructing Spanish colonization e fforts i $\mathrm{n} t$ he $\mathrm{r}$ egion $\mathrm{t}$ hat now constitutes $\mathrm{t}$ he ba se of $\mathrm{t}$ he $\mathrm{m}$ ountain $\mathrm{r}$ ange $\mathrm{t}$ hat separates the Zulian Upar Valley from the northeastern frontier of Colombia. ${ }^{13}$ In 1722 Chourio arrived in this region with his contingent of $600 \mathrm{~b}$ lacks, a long w ith s everal families from the Canary Islands and others from Maracaibo. C aptain Chourio e stablished the Villa de Nuestra Señora $\mathrm{d}$ e $\mathrm{P}$ erijá ${ }^{14}$ as $\mathrm{w}$ ell a s th e $\mathrm{V}$ illa $\mathrm{V}$ ieja, w hich is s ituated a $\mathrm{f}$ ew mile s c loser to th e mountains. The importation of these Africans for the express purpose of the military pacification of the Motilones helps establish the uniqueness of the Afro-Zulian population in contrast to other Afro-Venezuelan groups, w ho de rived from m ore m ixed A frican ancestry and w ere 1 argely engaged in agricultural or ranching pursuits. ${ }^{15}$ That black soldiers were deployed by the Dutch, Portuguese and Spanish, and held special privileges both for themselves and their families, was well know $\mathrm{n} t$ hroughout $\mathrm{t}$ he $\mathrm{T}$ rans-Atlantic $\mathrm{w}$ orld $\mathrm{f}$ rom $\mathrm{t}$ he $\mathrm{s}$ ixteenth $\mathrm{t}$ hrough $\mathrm{t}$ he ni neteenth century.

\footnotetext{
${ }^{13}$ Findings of the Royal Commission at $\mathrm{M}$ aracaibo in favor of $\mathrm{J}$ uan $\mathrm{C}$ hourio de Iturbide, signed a nd sealed by Joseph Moreno de Santisteban, the public scribe and clerk of court, 5 September 1732. Archivo Histórico Nacional de Colombia (Ciudades de Venezuela), Catálogo R-6:66-84, Public Library, Mérida, Venezuela. The Commission was presided over by the visiting attorney and Judge Chancellor of the City of Santo Domingo Royal Commission, Juan Pérez Garzia, who took into account various statements filed for (by sundry Spanish colonial authorities) and against (by representatives of the Royal English Company) Don Juan de Chourio respecting the authenticity of the Royal Order dated 9 May 1722, and subsequent royal orders. It was the Royal Order of 9 May 1722 that granted Chourio the authority and funds to 1) establish a city and Capuchin mission in the valley lands at Perijá, 2) pacify the indigenous Motilones tribe in the regions surrounding both Perijá and Maraciabo, and 3) to take possession of four ships of S panish registry, $100 \mathrm{t}$ ons e ach, for the purpose of bringing i mmigrant families and goods free of taxation from the port of Cadiz, Spain, as well as 600 Africans to defend the outpost, to include their women in this number, also free of taxation, along with sufficient arms and munitions to satisfy the royal officers in Maracaibo that Chourio would be able to complete his mission. Judge Juan Pérez Garzia ruled in Chourio's favor, decreeing that Chourio should be released immediately and that all $\mathrm{h}$ is property, to include slaves and merchandise previously confiscated, should be returned to him, and also that he should be allowed to proceed unhindered to any and all parts of the Spanish Empire in the resumption of his business transactions. Three years later, Chourio's concessions were renewed. See Miguel de Villanueva, Secretary to the Spanish King, to Captain Juan de Chourio, 27 October 1735, Archivo H istórico N acional d e C olombia ( Ciudades d e Venezuela), C atálogo R -3:185-186, R -6:66-84, P ublic Library, Mérida, Venezuela.

${ }^{14}$ Geographic coordinates: $10^{\circ} 19^{\prime} 24,0^{\prime \prime} \mathrm{N}, 72^{\circ} 19^{\prime} 02,9 ” \mathrm{~W} \pm 4 \mathrm{~m}$ (measured from the Plaza Bolívar), Perijá, www.elbrollo.com (27 April 2009).

${ }_{15}$ Matthew Restall, "Black C onquistadors: Armed Africans in E arly Spanish America," The Americas 57:2 (October 2000): 175.
} 


\section{Literature Review}

In $\mathrm{r}$ eviewing th e e xisting lite rature r elating to the $\mathrm{h}$ istory of the A fro-Zulians in the transatlantic world, several general approaches and themes were identified. One may be termed the structural anthropological approach. S tructural anthropological research is carried on by the Ajé Foundation, founded by Juan de Dios Martínez Suárez in 1972. T his foundation sponsors investigation into the A frican or igins of the A fro-Zulian pe oples, m ost notably in those a reas linking music and culture.

As far as structural anthropological research, the Ajé Foundation carries out an ongoing investigation $\mathrm{i}$ nto $\mathrm{t}$ he A ngolan o rigins of $\mathrm{t}$ he A fro-Zulian $\mathrm{p}$ eoples, an $\mathrm{d}$ es pecially $\mathrm{t}$ heir chimbángueles (Angolan dr ums) and m usic. ${ }^{16}$ The $\mathrm{f}$ oundation of fers $\mathrm{t}$ he publ ic obj ective information about the Angolan origins and characteristics of the drums, music and dances which can be heard in the Sur del Lago communities of San José, Gibraltar, Palmarito and Bobures of the Sucre Municipality as well as the emergence of new syncretic forms of worship based on the fusion of C atholicism ( San B enito), C entral A frican or ishas ( principally Ajé), and indigenous myth (Mucúchies).

Martínez has publ ished varied works for both popular and scholarly audiences, and his work $\mathrm{h}$ as $\mathrm{b}$ een h elpful insofar as he i ndicated specific ethnicities in A ngola, w ith a s pecial emphasis on the Imbangala, and tied them to the first 600 Africans brought into the Sur del Lago

\footnotetext{
${ }^{16}$ John C. Super and Briane K. Turley, Religion in World History (New York: Routledge, 2003). 162. Music is a p owerful transmitter of culture, an "aural icon of power" that both invokes and symbolically represents power in the universe. The authors state that, "music is widely recognized as a potent force because of the deep and lasting effect it can have upon the emotions and intellect of humans.... This immersion in the sounds of ritual song conveys as surance to the believers that a sacred thing has, or soon will, occur." The relevance of this statement to the Afro-Zulians lies in the beating of the chimbángueles, heralding the arrival of the orisha Ajé in the iconic statue of San Benito, annually removed from his special chapel and carried in procession from village to village throughout the Sur del Lago during designated festival days.
} 
region b y C aptain J uan de C hourio in $1722 .{ }^{17}$ Therefore, w ith C hourio operating a cross the transatlantic world, through Martínez' work Chourio can, for a season, be linked to Angola. But by itself, this approach is not sufficient to provide a meaningful exposition of the topic.

A second type of research focused on A frican religions and their impact on V enezuela. While Martínez Suarez explored in-depth the connections with the West African orisha Ajé and the Catholic black saint, San Benito, ${ }^{18}$ the Venezuelan state-run oil concern, PDVSA historian L. A. Crespo, researched the religious s ignificance respecting the import of this Italian-Ethiopian worker of $\mathrm{m}$ iracles i nto the ove rall $\mathrm{V}$ enezuelan $\mathrm{m}$ ythos. ${ }^{19}$ And c ultural e thnologists Y sabel Balza Santiago and Juvenal Rangel ${ }^{20}$ explained how the cult of the black saint transferred to the indigenous Mucuchíes of the mountainous Mérida state, and the patriotic and wondrous visions ascribed to him. T his dissertation fuses these disparate elements into an integral an $\mathrm{d}$ s ecular view with $\mathrm{r}$ egard $\mathrm{t}$ o t he e mergence of $\mathrm{S}$ an $\mathrm{B}$ enito in $\mathrm{t}$ he pa ntheon of Venezuelan $\mathrm{r}$ eligious experience and history. In addition, this dissertation compares the cult of $\mathrm{S}$ an $\mathrm{B}$ enito to other forms of syncretic religion manifested throughout Venezuelan history, such as María Lionza, ${ }^{21}$ the Black Panther Woman, ${ }^{22}$ and San Juan Bautista. ${ }^{23}$

\footnotetext{
17 Juan d e D ios.Martínez S uárez, Como Bailar Chimbángueles: Colección Danzக்க́łnicas y Tradicionales (Maracaibo: Fundación Ajé, 1991), 5, 10.

${ }_{18}$ Juan de D ios Mar tínez Suarez, El culto a San Benito de Palermo en Venezuela (Maracaibo: C ultura d e la Universidad de Zulia, 1999).

${ }^{19}$ Luis Alberto Crespo, Venezuela: Tierra Mágica (Caracas: Corpoven- affiliate of PDVSA, the state-owned oil concern), pamphlet, undated (ISBN 980-259-525-V).

${ }^{20}$ Ysabel B alza S antiago and Juvenal R angel, "Mucuchíes honra a San Bentio de Palermo", Revista Bigott 42 (March-June 1997).

${ }^{21}$ Hercilia Garnica, “Humedad y corrosión debilitaron estructura de María Lionza.” El Nacional (Caracas ), 7 June 2004. The a uthor e xplains ho w normal wear a nd tear ha s weakened a s tatue in honor of María Lionza in Caracas. S he al so $d$ etails the o rigin o $\mathrm{fthis}$ cu $\mathrm{lt}$ i $\mathrm{n}$ terms o $\mathrm{f} s$ yncretic $\mathrm{r}$ eligion a nd the meaning $\mathrm{it}$ has for contemporary Venezuelans of all races.

${ }^{22}$ Berta E. P érez, "The J ourney to F reedom: M aroon F orebears in S outhern V enezuela," Ethnohistory 47:3-4 (Summer-Fall 2000): 623, 624.

${ }_{23}$ David M. Guss, "The Selling of San Juan: The Performance of History in an Afro-Venezuelan Community," American Ethnologist 20:3 (August 1993): 451-473.
} 
Another important theme is resistance. Resistance and struggle against both slavery and the Spanish empire find expression in numerous historical works. For example, the research of Jeremy Cohen of the University of Florida, serves to provide little doubt that blacks of the Sur del Lago joined with other Afro-Venezuelans in the colonial era up through independence to aid and a bet pi rates a nd other e nemies of the S panish C rown. A ccording to $\mathrm{C}$ ohen, freed blacks from various ports in the Netherlands Antilles w ere signed on to schooners that would ply the coasts of Venezuela. T hese freed b lacks act ed as a gents of the D utch, furthering s muggling operations a gainst $\mathrm{S}$ pain a nd e stablishing $\mathrm{s}$ undry commercial a nd $\mathrm{s}$ trategic contacts $\mathrm{w}$ ithin Venezuela, to include blacks and pardos of varied status as possible recruits to Dutch Caribbean operations. ${ }^{24}$ If a Venezuelan black or pardo were to join the ranks of the Dutch smugglers, they would be released on their own once the ship returned to Willemstad, or some other Dutch port, and the crews broke up. Each individual could go their own way, "seeking the next opportunity to cruise the Caracas coast." 25

Many o ther A fro-Venezuelans in the c olonial e ra up $\mathrm{t}$ hrough independence fled from their masters when occasions permitted and augmented the ranks of maroon communities. Jesús María Herrera Salas investigated one of these maroon communities and its leader in depth. ${ }^{26}$ In 1553, Miguel del Barrio, popularly known as "El Negro Miguel,” led a full-blown slave rebellion on the mines and plantations of Nueva Segovia de Buría. Herrera shows how Miguel went from village to $v$ illage in th is p rovince, lib erating the $\mathrm{s}$ laves and le ading them to the la nds of the Jirahara i ndigenous $\mathrm{p}$ eoples, $\mathrm{w}$ hence an A frican-style ki ngdom a long $\mathrm{w}$ ith a $\mathrm{j}$ udicial a nd

\footnotetext{
${ }^{24}$ Jeremy Cohen, Department of History, University of Florida, "Smuggling in Eighteenth Century Venezuela: The Role of th e Práctico," u npublished a ddress t o the $27-29$ M arch $2003 \mathrm{~m}$ eeting of the L atin A merican S tudies Association at Dallas, Texas.

${ }^{25}$ Cohen, "Smuggling in Eighteenth Century Venezuela," 5.

${ }^{26}$ Jesús María Herrera Salas, El Negro Miguel y la primera revolución venezolana: la cultura del poder y el poder de la cultura (Caracas: Vadell Hermanos, 2003).
} 
ecclesiastical h ierarchy was es tablished in the interior of $\mathrm{V}$ enezuela o $\mathrm{n}$ ands g ranted to the runaway blacks bythe indigenous caciques (chiefs). Herrera g oes so $\mathrm{far}$ as to classify the rebellion of Miguel as Venezuela's first true revolution, which he asserts passed through four distinct phases:

1) attacks on crown property in the mines and plantations of Nueva Segovia de Buría, 2) the establishment of an independent political organization, 3) the formation of economic, military, political and r eligious a lliances $\mathrm{w}$ ith the $\mathrm{J}$ iraharas, and 4 ) a uni ted $\mathrm{d}$ efense against $\mathrm{S}$ panish efforts to repress the revolution. M iguel was ul timately uns uccessful as a consequence of the overwhelming forces arrayed against him and his people. ${ }^{27}$

Afro-Venezuelans, t o i nclude A fro-Zulians, fought w hen $\mathrm{n}$ ecessary against t he e vils perpetuated against them by colonial administrators and slave masters. As independence loomed on the horizon, both Afro-Zulians and A fro-Venezuelans aligned themselves with parties partial to both the French and Haitian revolutions. ${ }^{28}$ For the significance of events on $\mathrm{t}$ he ground in Haiti to th e e ntire A fro-Caribbean an d circum-Caribbean world, a s w ell a s to the lite rature review, there is no finer chronicler and analyst than C. L. R. James. ${ }^{29}$ The Haitian revolution struck fear into the entire plantation economy. The ow ners of slaves could not sleep, unaware when revolting slaves would cut their throats from ear to ear. Restricting access to information about the French and Haitian revolution thus became a primary concern for slave holders.

Bohórquez and Enrique demonstrate how Afro-Venezuelans aligned themselves with the revolutionists, M anuel Gual and J osé M aría E spaña, who s taged an insurrection b ased on the ideals of abolition and the French declaration on the Rights of Man and the Citizen (1789), on the

\footnotetext{
${ }^{27}$ Ibid., 104.

${ }^{28}$ Federico Brito Figueroa, 30 Ensayos de Comprensión Histórica: Colección Historia 25 (Caracas: Universidad Central de Venezuela, Ediciones de la Biblioteca, 1997).

${ }^{29}$ C. L. R. James, Black Jacobins: Toussaint L'Ouverture and the San Domingo Revolution (New York: Random House, 1963).
} 
Coro pe ninsula in 1797. M any A fro-Zulians a lso pa rticipated in $\mathrm{t}$ his insurrection, a nd the referenced documents provide particular insight into their awareness of revolutionary ideals and their willingness to even die for them. ${ }^{30}$

For s pecific Haitian contributions to the efforts of the Creole revolutionaries $\mathrm{F}$ rancisco Miranda, Simon Bolivar and the A fro-Venezuelans in their fight for independence from Spain, the author of this dissertation has come upon a one-time, limited print edition of the discourses presented on $30 \mathrm{O}$ ctober 1953 to commemorate the erection of an equestrian statue to the great Venezuelan liberator Simon Bolivar in Port Au Prince, Haiti. ${ }^{31}$ This will add something new to the academy with respect to the emergence of a genuine A frocentric perspective in an era when European liberal positivist philosophy prevailed among most Latin American historians. ${ }^{32}$

This is d esirable, as the resistance theme $\mathrm{h}$ as $\mathrm{n}$ ot, in ev ery cas $\mathrm{e}, \mathrm{p}$ rovided an a ccurate account of the role of $b$ lack $V$ enezuelans. In $\mathrm{f}$ act, f rom $1937 \mathrm{t}$ o the $\mathrm{p}$ resent, the $\mathrm{c}$ elebrated Venezuelan historian Arturo Uslar Pietri, with the greatest influence on the white elite, has kept the official discourse alive in his writings and addresses to Venezuelan intellectuals concerning issues of m odernity and the na tion. Uslar P ietri's pr emise is in ke eping with the nor ms of European liberal positivist philosophy, that being that "blacks did not arrive in Venezuela with a culture that visibly affected the construction of our nation identity." ${ }^{33}$ He actually believes that if Venezuelans do not $\mathrm{s}$ ucceed i $\mathrm{n}$ " substantially modifying $\mathrm{t}$ he e thnic $\mathrm{c}$ omposition of our population, it will be virtually impossible to change the course of our history and to make our

\footnotetext{
${ }^{30}$ López B ohórquez, A lí Enrique, r edactores, Manuel Gual y José María España: Valoración múltiple de la conspiración de La Guaira de 1797 (Caracas: Comisión Presidencial del Bicentenario de la Conspiración de Gual y España, 1997).

31 Marcos $\mathrm{P}$ érez J ímenez, Colonel an $\mathrm{d} \mathrm{P}$ resident o $\mathrm{t} \mathrm{t}$ he Republic of Venezuela, a uthorized $\mathrm{p}$ ublication a s a “souvenir," Inauguración de la estatua ecuestre del Libertador en Haití (Caracas: Imprenta Nacional, 1954).

${ }^{32}$ Arturo U slar P ietri, 1983 , as ci ted in Senta E ssenfeld de B ruwer, La cara oculta del desarrollo (Caracas: Ediciones Monte Ávila, 1987), 16, and Uslar Pietri, El país necesita inmigración (Caracas: Boletín de la Cámara de Comercio de Caracas, February 1937), 235.

${ }^{33}$ Pietri, La cara oculta, 16.
} 
country a modern nation." 34 Implicit in this type of liberal positivism is an embedded racism at all strata of Venezuelan society.

Nevertheless, for a n e xcellent s ynthesis of i nsurrectionist ferment a nd the c reation of radical political movements throughout the Americas in the age of revolutions, the most recent and comprehensive w ork of Lester D. Langley can be consulted. ${ }^{35}$ He as serts that $n$ either the American, French/Haitian or Latin American revolutions can be viewed as singular events. They are all intricately interconnected as a transatlantic revolution.

There is a lso a s ubstantial lite rature relevant $\mathrm{t} o$ th is $\mathrm{d}$ issertation th at focuses o $\mathrm{n}$ th $\mathrm{e}$ African continent, s pecifically the e arly hi story of the A ngolan i nterior. F rom the w orks of Joseph Miller, Beatrix Heintze and others, for example, we learn much about the origins of the Imbangala, the primary ethnic group composing the Kasanje kingdom. From these studies, we also l earn that the Imbangala, like the P ortuguese, w ere invaders of the territory that be came Angola. Miller's work is particularly significant in identifying the earliest documentary citation of the term "Imbangala." A ccording to Miller, ${ }^{36}$ this citation of the "Imbangala" is found in a letter from a Portuguese Jesuit brother who accompanied Paulo Dias de Novaes. ${ }^{37}$ In the letter, written in 1563 , the cleric relates that the armies of the ngola a kiluanje had recently fought a series of battles somewhere in the interior of Angola against a ruler simply known as the "King of $\mathrm{B}$ enguela." $\mathrm{M}$ iller believes th at th is $\mathrm{K}$ ing o $\mathrm{fB}$ enguela $\mathrm{w}$ as c ertainly the $\mathrm{k}$ ing o $\mathrm{ft}$ he Imbangala, o ne o f the Lunda makota who had t aken ov er the kilombo. A lso, the w ord "Imbangala", i n t he c ontemporary A ngolan 1 anguage of U mbundu, s ignifies a "brave a nd

\footnotetext{
${ }_{34}^{34}$ Pietri, El país necesita inmigración, 235.

${ }^{35}$ Lester D. Langley, The Americas in the Age of Revolution,1750-1850 (New Haven: Yale University Press, 1998).

${ }^{36}$ Joseph C. Mi ller, "The I mbangala a nd the C hronology of Early Central African History," Journal of African History, XIII, 4 (1972): 561.

${ }^{37}$ Letter of Irmão António Mendes to the Father General, 9 May 1563, in António Brasio, Monumenta Missionaria Africana, 2 vols. (Lisbon: Agência Geral do Ultramar, 1952-65), II: 509.
} 
courageous person, especially on e who has no s ettled home." 38 Thus, the Umbundu definition seems h ighly appropriate, as it ap tly fits the $\mathrm{w}$ arrior caste of the Imbangala, em bodied as a transitive social institution with military and political functions. This also ties in nicely with the term kilombo or quilombo, ${ }^{39}$ which in B razil and ma ny parts of Latin A merica ta kes o $\mathrm{n}$ the meaning of a w ar c amp or a s ettlement of fugitive s laves. I f $\mathrm{n}$ ot for M iller's c onscientious research, ho wever, $t$ he groundwork $w$ ould not ha ve $b$ een 1 aid $w$ hereby $t$ hese $c$ onnections between the Imbangala and fugitive slave settlements in Brazil and other parts of South America have been made.

The work of Heintze, moreover, provides additional perspectives on the Imbangala. She notes, $\mathrm{f}$ or e xample, th eir $\mathrm{r}$ ole in th e Atlantic s lave tr ade: " The $\mathrm{n}$ orthern groups o $\mathrm{f}$ Jaga/Imbangala had in the meantime become ev er more essential to the Atlantic slave trade, a number s upporting the Portuguese in their campaigns and finally crossing the K wanza to the north. At the beginning of the tenure of the Portuguese governor Luís Mendes de Vasconcelos (1617-21) one finds the 'Jaga' groups under the leaders Kasa Kangola, Donga,and Jão Kasanje involved in and siding with the Portuguese in battles against the kingdom of Ndongo...."40

Coming f rom $\mathrm{C}$ entral A frica s ometime a round the $\mathrm{s}$ tart of $\mathrm{t}$ he $\mathrm{s}$ ixteenth $\mathrm{c}$ entury, $\mathrm{t}$ he Imbangala occupied vast portions of the east; while the Portuguese, expanding southward from the Gold Coast (present-day Ghana) and always on the lookout for suitable harbors to construct new port facilities, established a settlement at the Bay of Benguela in 1617, with the purpose of seeking out new entrances into the Angolan hinterland, thereby affixing their hegemony over the

\footnotetext{
${ }^{38}$ Albino Alves, Fr. Dicionário etimolólogico Bundu-Portugues, 2 vols.(Lisbon, 1951), I:664.

${ }^{39}$ Hebe Mattos, "Black Troops and Hierarchies of Color in the Portuguese Atlantic World: T he Case of Enrique Dias and His Black Regiment," Luso-Brazilian Review 45:1 (2008): 15, 16

${ }^{40}$ Beatrix H eintze, "The E xtraordinary J ourney o f t he J aga t hrough t he Centuries: Critical Approaches to Precolonial Angolan Historical Sources," History in Africa 34 (2007): 81.
} 
southwest of $\mathrm{t}$ he A frican $\mathrm{c}$ ontinent. $\mathrm{T}$ his po $\mathrm{rt}$ ultimately $\mathrm{b}$ ecame th $\mathrm{e} \mathrm{n}$ ucleus o f s laving operations, which reached their peak around 1720.

As it has been demonstrated that the Imbangala were a m ilitary society, another area of the 1 iterature $\mathrm{r}$ eview i nvolves the e ngagement of a rmed bl ack c ontingents. Apart fro $\mathrm{m} t$ he capacity of common slave, some Africans served as both unarmed and armed auxiliaries. ${ }^{41}$ The majority of these hailed from West Africa, although a smaller contingent came directly from the Iberian kingdoms in the early decades after the Spanish had crossed the Atlantic. During the first century of $\mathrm{c}$ onquest i $\mathrm{n} \mathrm{t}$ he A mericas, how ever, $\mathrm{t}$ he $\mathrm{m}$ ilitarized e nvironment $\mathrm{m}$ ade $\mathrm{i}$ t of ten difficult to distinguish between the unarmed and armed auxiliaries. Therefore, the experience of black a uxiliaries in a ny milita ry c apacity, i. e. f oot s oldier, in telligence, lo gistics, ma ritime operations, etc., markedly differed from that of the mass of common slaves. The black soldier could function as an individual, a lone or in s mall detachments, as well as in the capacity of a personal dependent or agent of a Spanish master. In addition, while some entered into military service in the capacity of slave, they were more likely than their enslaved counterparts to acquire their freedom, s hould they s urvive a few e nemy engagements. $T$ he enslaved obt ained their freedom soon after they commenced fighting alongside the Spaniards, if not sooner, and Restall notes that, "very few black conquistadors seem to have remained slaves after their participation in the Conquest." 42

Inasmuch a $\mathrm{s} \mathrm{C}$ hourio br ought $\mathrm{s}$ uch a $\mathrm{n}$ a uxiliary contingent $\mathrm{i}$ nto the a rea that now comprises Zulia state in Venezuela, it can be deduced from historical knowledge that the men of that A fro-Zulian de tachment held predictable pos ts, ${ }^{43}$ becoming part of colonial life in various

\footnotetext{
${ }^{41}$ Restall, "Black Conquistadors," 173-175.

42 Ibid., 175.

43 Mattos, "Black T roops," 15, 16. The P ortuguese C rown utilized black soldiers on bot h sides of the A tlantic, principally i $n$ Angola an d Brazil, t hroughout the seventeenth cen tury. $\mathrm{T}$ he I mbangala, a. k.a. J agas b y t he
} 
ways. J uan de Dios Martínez Suarez, an ethnographer and musicologist from the University of Zulia, has indicated that $\mathrm{m}$ any of the initial 600 , br anded on $\mathrm{t}$ heir bodi es ${ }^{44}$ with the na me of Chourio, later went on to become well known as effective hacienda managers. ${ }^{45}$ Their diffusion across $\mathrm{pl}$ antations of the $\mathrm{S}$ ur de 1 Lago a lso a llowed them to pe rpetuate the $\mathrm{c}$ ult of the $\mathrm{W}$ est African orixa Ajé among the slaves they found under their supervision. The mass of slaves were mostly of Angolan descent and recognized the Imbangala origins of the branded Chourios.

Therefore, even though the Chourio band were few in number, the a vailable literature indicates th at th eir liv es $\mathrm{s}$ ufficiently conformed to $\mathrm{c}$ ertain $\mathrm{p}$ atterns that a llow a nalytical generalizations $\mathrm{t} \mathrm{o} \mathrm{b}$ e $\mathrm{m}$ ade a bout $\mathrm{t}$ hem, $\mathrm{t}$ hus a llowing $\mathrm{t}$ hem $\mathrm{t} \mathrm{o}$ constitute $\mathrm{t}$ hemselves as a $\mathrm{n}$ important part of the bl ack experience in colonial S panish A merica and the A fro-Venezuelan legacy. It can also $\mathrm{b}$ e $\mathrm{s}$ een $\mathrm{t}$ hat $\mathrm{t}$ he $\mathrm{p}$ erspectives $\mathrm{g}$ ained $\mathrm{b}$ y researchers of $\mathrm{A}$ frican $\mathrm{h}$ istory, comparative r eligion, resistance a nd s tructural a nthropology are vi tal to the out comes of this dissertation.

Portuguese, were known as fierce warriors in C entral A ngola, an $\mathrm{d} h$ ad al lied themselves for a s eason with $\mathrm{the}$ Portuguese in fighting as their proxies in those interior areas to the east of Luanda. T hey were exclusively male groups whose members lived in militarized camps, called ki-lombos. Interestingly, the counter-conquistador maroon communities which later sprung up in Brazil were called quilombos, so named because of their alleged Imbangala leadership and military structure. The ki-lombos in A ngola c onstituted a n a lliance a mong young warriors who rejected traditional kinship structures and the supremacy of the elders, much as the quilombos of B razil rejected traditional Portuguese colonial structures and the supremacy of the Portuguese Crown. In Angola, the Portuguese military a dopted th e ta ctics and o rganizational forms of the I mbangala, $r$ econstituting their force in to $\mathrm{s}$ mall contingents, al lied i n o perations with a $\mathrm{v}$ ariety o $\mathrm{f} 1$ ocal A frican forces, $\mathrm{t}$ o i nclude $\mathrm{p}$ rivate ar mies o f $\mathrm{r}$ egional authorities (sobas). Imbangala armed groups allied with the Portuguese as mercenary troops and slave regiments to form the so-called guerras pretas (black troops), with each guerra preta considered a small infantry force. The Portuguese military leader, Henrique Dias, himself of the Imbangala, was proclaimed by King João IV of Portugal as "Major of All Black Troops in Angola and Brazil" on 16 November 1644. As is demonstrated further on in this dissertation, the Brazilian maroons in the quilombos of Palmares and surrounding areas shared much in common with the Afro-Zulians of the Sur del Lago.

${ }_{44}^{44}$ María Alejandra Carrillo, "En la tierra de los hijos de Ajé,” Panorama (Maracaibo), 16 June 2002.

45 Juan de Dios Martínez Suárez, Como Bailar Chimbángueles: Colección Danzas Étnicas y Tradicionales No. 1 (Maracaibo: Fundación Ajé, 1991), 5. "A fact of great significance is the following: There existed slaves that were dedicated to the work in the homes of the masters a nd not to the ta sks of the field. These r eceived a better instruction about the cultural values of the Europeans, but also exercised the capacity to compare, and hence, put a greater value on their African traditions. This advantage, in comparison to those who worked on the plantations guarded by the henchmen of the masters, oriented them to leadership in the search for their identity and to succeed in defining just what it was they were going to be in the New Africa (term of black nationalist identification for the Sur del Lago region used by some Afro-Zulians)." 


\section{Methodology}

These published sources constitute an important literature that provides information upon which the dissertation may be founded. Even more important, however, are the primary sources utilized. First, in the General Archives of the Nation in Caracas, there is the principal repository of documents related to Venezuela's black population. O ther areas to search out, by degree of importance, are the archives of the Archbishop of Caracas and some of the registers from major city administrations (cabildos), such as Caracas, Maracaibo or Mérida. The General Archives of the Nation are divided into three major epochs: the colony, the struggle for independence, and the republic. Naturally, the first is quite rich in documentation relating to the importance of the slaves, the ethnic composition of these slaves, their purchase and sale, the names of their owners, diverse r egulations pertaining to s laves and the slave trade, titles of ow nership to s laves, etc., especially during the eighteenth century. It is in these files where a wealth of material pertaining to Juan ${ }^{46}$ de Chourio and the Africans he transported to the Sur del Lago Maracaibo region can be found.

The doc uments relative to the A fricans and their de scendents, how ever, ha ve not been grouped in a section apart. Notices about African slaves can be found in all three parts. Relative to the colonial era, the notices are divided among the following sections: royal licensures, royal orders and p rovisions, c ity a dministrations, c auses of resistance, family and $\mathrm{m}$ arriage records, designation of work details, local governments and local military detachments, tax and customs houses, exhortations on $\mathrm{m}$ aintaining the pu rity of S panish blood, r oyal legates, commissars to indigenous popul ations, $\mathrm{r}$ eligious or ders a nd Papal bul ls, c ontracted c ompanies i n s laving enterprises, plantation records, shipping records, church ne gotiations, the collection of titles by the $\mathrm{c}$ hurch, publ ic he alth de crees, a nd publ ic e xpense 1 edgers. A nd i nasmuch a s the s laves

\footnotetext{
${ }^{46}$ In Spanish documents Jean de Chourio is referred to as "Juan de Chourio" or "Juan de Chourio de/e Iturbide."
} 
formed the p rimary s ector of the working $\mathrm{c}$ lass during the $\mathrm{c}$ olonial $\mathrm{e}$ ra, it is a lso pos sible to encounter references to them in al most any other type of record that has come to be preserved down $\mathrm{t}$ o our $\mathrm{t}$ ime. Nevertheless, $\mathrm{t}$ he pr incipal $\mathrm{s}$ ections i $\mathrm{n}$ which $\mathrm{A}$ frican $\mathrm{m}$ aterial can be referenced for the colonial era are under local government (gobernación), military detachments (Capitania General), military administration (Intendencia del ejército), tax administration (Real hacienda), ro yal a ffairs ( Real consulado), $\mathrm{m}$ iscellaneous af fairs (Diversos), f amily co urt an $\mathrm{d}$ matrimony (Diseños y matrimonios), an d royal ch artered s lave companies l ike the Compañía Guipuzcoana.

During t he 1950s a nd 1960s, i nvestigators of A fro-Venezuelan c ulture 1 ike doc tors Federico B rito F igueroa ( economics of s lavery) a nd $\mathrm{M}$ iguel $\mathrm{A}$ costa $\mathrm{S}$ aignes ( the $\mathrm{c}$ ulture of slavery), established credibility in their w ork by digging d eeply into these resources, and both these e xperts w ere, in turn, frequently quot ed by doctors Angelina P ollak-Eltz ( anthropology) and J esus G arcía (Africana s tudies). S ome d ocuments from the General A rchives, and many pertaining to the Afro-Venezuelans, have been subsequently collected by Arellano Moreno and published in sundry editions: Sources on the Economic History of Venezuela in the Sixteenth Century, Documents on the Economic History of Venezuela and the Relationship of Venezuelan Geographic Areas (Caracas: Biblioteca de la Academia Nacional de la Historia, 1993), XIV.

The tomes of diverse collections in the General Archives of the Nation possess an index. For certain collections an index was later added in the form of an attached notebook. It should be $\mathrm{m}$ entioned $\mathrm{t}$ hat $\mathrm{t}$ he $\mathrm{f}$ ormer s ections, $\mathrm{f}$ alling unde $\mathrm{r} t$ he $\mathrm{t}$ itle of Translados (Transferred Documents), contain 670 volumes, of which a good deal were taken from the Archivos de Indias (Archives of Spanish America). 
As to the second epoch, relevant to the Bolivarian revolution and the era of the struggle for independence, m ost r eferences t o blacks in the General A rchives can be found und er the categories of administration (Intendencia), the ca uses of disloyalty (Causas de deslealtad), the government of G uyana ( la gobernación de Guyana), the i llustrious 1 eaders of independence (Ilustres próceres de la independencia), t he Court of $\mathrm{N}$ aval J urisdiction (El Corte de Almirantazgo) and the correspondence of the founding fathers (La correspondencia de próceres).

Corresponding $t o$ the th ird e poch, the founding of $t$ he $r$ epublic a nd the a bolition of slavery, the sections on interior affairs and justice (Interior y Justicia), customs, war and the sea (Hacienda, Guerra y Marina), publ ic w orks and publ ic servants, de velopment a nd e ducation, etc., are all important with regard to black people, but especially interior affairs and justice. The documents from these sources were particularly helpful to John V. Lombardi in the construction of hi s s ignificant w ork, The Decline and Abolition of Negro Slavery in Venezuela. These guidelines $\mathrm{w}$ ere publ ished, i $\mathrm{n} \mathrm{S}$ panish, $\mathrm{b}$ y t he $\mathrm{U}$ nited $\mathrm{N}$ ations $\mathrm{O}$ rganization on $\mathrm{E}$ ducation, Science and Culture, he adquartered at $\mathrm{place}$ de Fonteney, $75 \mathrm{P}$ aris $7^{\mathrm{e}}$, and printed by SainteCatherine, Brujas, in Belgium, 1970.

There is also a plethora of material related to the origin and growth of rituals surrounding the Roman Catholic/African/Amerindian syncretic cult of San Benito in the Sur del Region and throughout $\mathrm{V}$ enezuela. $\mathrm{T}$ hese a re $\mathrm{s}$ ignificant i $\mathrm{n} \mathrm{t}$ hat they hi ghlight $\mathrm{t}$ he ad aptation an $\mathrm{d}$ modification of Eurocentric belief s ystems to accommodate New W orld realities. B y in fusing African and indigenous peoples' beliefs and values into the pantheon of Roman Catholic saints, oppressed peoples of color found a vehicle to not only endure and preserve essential elements of their culture, but also transmit it across time for future generations to unveil its deeper meanings. Much of this material has been archived by Roberto "Diken" Carlos López, director of the Afro- 
Asian Institute of the University of the Andes in Mérida, Venezuela. López, under the auspices of $t$ he uni versity, di rects $t$ he a ctivities of $t$ he $B$ ambata $P$ roject a nd $f$ requently conducts investigations and seminars into the evolution of the San Benito cult. The research will include information $g$ ained from interviewing López on $t$ he i mpact of San B enito on bo th the A froZulians and the Bolivarian Republic of Venezuela.

\section{African Diaspora Theory}

In approaching $\mathrm{t}$ his ar ea, a $\mathrm{p}$ aradigm i s em ployed that $\mathrm{p}$ rovides a co mparative an $\mathrm{d}$ theoretically integrated approach to the African diaspora within a worldwide context. This new paradigm would also serve to link the historical development of the A frican peoples of the Sur del L ago Maracaibo in V enezuela ( Afro-Zulian) w ith the global or international ne twork of African diaspora peoples. This conceptual and research framework is clearly on the cutting edge of change as it contributes to a refinement of the theory and method of studying the survival and persistency of the A fro-Zulian pe ople over time and cross-culturally as an in tegral part of the Trans-Atlantic community. The interdisciplinary nature of the concepts and principals will be useful i $\mathrm{n} \mathrm{s}$ haping bot $\mathrm{h} t$ he $\mathrm{t}$ hinking and di rection of $\mathrm{r}$ esearchers i $\mathrm{n} t$ he $\mathrm{f}$ ield $\mathrm{f}$ rom va ried backgrounds and epistemological orientations in both the humanities and social sciences.

Elliot Skinner, for example, has stated that the growth of any new intellectual discipline has followed a $\mathrm{t}$ hree-stage pr ogression. ${ }^{47}$ The $\mathrm{f}$ irst $\mathrm{s}$ tage $\mathrm{i} \mathrm{s} \mathrm{t}$ he pe riod of de lineation a nd definition. This embodies all the excitement inherent in the pioneering experience of exploring new $\mathrm{f}$ rontiers, and $\mathrm{f}$ or $\mathrm{t}$ his di ssertation $\mathrm{w}$ ould i nvolve $\mathrm{t}$ he a ccumulation of $\mathrm{t}$ hat $\mathrm{i}$ nformation indicating the existence of an Afro-Zulian community. The second stage is essentially a microlevel fact finding stage and embodies the time when the concepts and definitions that emerged

\footnotetext{
${ }^{47}$ Remarks $\mathrm{m}$ ade by E lliot S kinner, F ranz B oas P rofessor of A nthropology, C olumbia U niversity, conference, "Transformation and Resiliency in Africa," 12-13 October 1977, at Washington DC.
} 
from the first stage would be utilized to form a detailed case study and field research. For this dissertation it means the incorporation of those primary documents cited in the first stage dealing with the $\mathrm{c}$ ase of J uan $\mathrm{d}$ e $\mathrm{C}$ hourio a nd the 600 blacks he brought ov er to the $\mathrm{S}$ ur $\mathrm{d}$ el Lago Maracaibo in 1722, who came to form the nucleus of the Afro-Zulian community. And the third and $\mathrm{f}$ inal $\mathrm{s}$ tage $\mathrm{i} \mathrm{s} t$ hat of $\mathrm{m}$ aturation. A $\mathrm{t} t$ his poi $\mathrm{nt}$ i $\mathrm{n}$ the de velopmental process, a $\mathrm{m}$ ore systematic a ssessment of the collected body of $d$ ata will emerge, with tw o major th rusts. The first of these would be challenges to, or the reinterpretation of, the original conceptual models, and the s econd of these w ould be the formulation of ne w m odels bui lt upon $t$ he know ledge gained in the first two stages, but simultaneously suggesting innovative theoretical approaches or untried avenues of exploration.

Moreover, th is $\mathrm{d}$ issertation $\mathrm{w}$ ill ta ke a $\mathrm{n}$ in tegrative a pproach to th e African $\mathrm{d}$ iaspora, drawing a ttention $\mathrm{t}$ o $\mathrm{t}$ hose 1 inkages of $\mathrm{A}$ frican pe oples $\mathrm{t}$ hroughout $\mathrm{t}$ he $\mathrm{C}$ aribbean a nd $\mathrm{t}$ he Americas, a s w ell a s w ith s pecific A frican s ocieties. T here is little d oubt th at the A frican diaspora $\mathrm{r}$ epresents a $\mathrm{t}$ ype of $\mathrm{s}$ ocial grouping $\mathrm{c}$ haracterized $\mathrm{b}$ y an $\mathrm{h}$ istorical pa tterning of particular social relationships an d ex periences. A s a s ocial formation, the A frican diaspora is conceptualized a s global aggregate of actors and subpopulations differentiated in s ocial and geographical space yet exhibiting a commonality based on hi storical factors and conditioned by and within a world ordering system. Among the characteristics that distinguish the diaspora, and hence the A fro-Zulians, as part of a global formation from other differentiated groups, are the following based on historical factors:

- Migration and Geo-Social Displacement: The Circularity of a People. This embodies th $\mathrm{e} h$ istorical d ialectic $\mathrm{b}$ etween $\mathrm{g}$ eographical mo bility a nd th $\mathrm{e}$ establishment of "roots."

- Social O ppression: $\mathrm{R}$ elations of $\mathrm{D}$ omination a nd $\mathrm{S}$ ubordination. This encompasses the conflict, di scrimination a nd i nequity, ba sed $\mathrm{p}$ rimarily, although not exclusively, on race, color, class and gender. 
- Endurance, Resistance, and Struggle: Cultural and Political Action. This area takes into account the creative actions of a people as subjects of their history, thus m obilizing a ction "for $i$ tself," $i$.e. changing the forms and c ontext of struggle. It a lso c oncerns $i$ tself $w$ ith ps ycho-cultural a nd id eological transformations, as well as the social networks and institutional dynamics. ${ }^{4}$

In this dissertation, all of the above should be incorporated into each s ection, with the final ch apter $\mathrm{r}$ eserved $\mathrm{f}$ or $\mathrm{h}$ istorical an alysis an $\mathrm{d}$ i nterpretation $\mathrm{t}$ hat $\mathrm{r}$ eflects M olefi A sante's "Afrocentricity." ${ }^{49}$ Basically, Afrocentricity is seen by Asante as a mode of thought or action in which the centrality of African interests, values and perceptions predominate. In the case of the Afro-Zulians, this would mean the placing of them, as African people, at the center of analysis of what is essentially an African phenomenon, i.e. their dispersion to the Sur del Lago Maracaibo, Venezuela, and the establishment of an essentially Angolan community there. In terms of action and $b$ ehavior, it $r$ epresents a devotion to the id ea that $w$ hat is in the b est in terest of A frican consciousness is a $\mathrm{t}$ the he art of e thical be havior. In $\mathrm{t}$ his e ndeavor, A frocentricity s eeks t o enshrine the idea that blackness itself encapsulates a body of ethics. In other words, being black means that one is against all forms of oppression, racism, classism, sexism, etc. ${ }^{50}$

In this dissertation, A sante's A frocentricity theory will form the fourth category of data analysis and interpretation, essentially encompassing the emergence of a new Afro-Venezuelan, and ev en m ore s pecifically, an A fro-Zulian i dentity. A n associate and co lleague of A sante, professor of $\mathrm{H}$ istory a nd $\mathrm{C}$ hair of $\mathrm{H}$ istory, $\mathrm{G}$ eography a nd $\mathrm{G}$ lobal $\mathrm{S}$ tudies a t $\mathrm{C}$ oppin $\mathrm{S}$ tate

\footnotetext{
${ }^{48}$ Ruth S imms Hamilton, “Toward a Paradigm for African Diaspora S tudies," in Monograph No. 1: Creating a Paradigm and Research Agenda for Comparative Studies of the Worldwide Dispersion of African Peoples, ed. Ruth Simms Hamilton (East Lansing, Michigan: African Diaspora Research Project, Michigan State University, 2007), 18.

${ }^{49}$ Molefi Asante, Afrocentricity: The Theory of Social Change (Chicago: African American Images, 2003), 2.

${ }^{50}$ Jean Paul Sartre, Black Orpheus (Paris: Edition Gallimard, 1948), 11. As a precursor to Asante's Afrocentricity, Sartre co ncluded t hat $\mathrm{t}$ he $\mathrm{d}$ evelopment of a $\mathrm{r}$ evolutionary $\mathrm{c}$ onsciousness e merged $\mathrm{f}$ rom a $\mathrm{n} u$ nderstanding a nd appreciation of the struggles of A frican peoples, rising up from the bottom of history to take their rightful place as equals a mong humankind. To this end, Sartre addressed his poetry and other writings to the whites of twentieth century France, to help them understand their deteriorating position in the grand scheme of history. If it could be arranged, Sartre would have these whites jump out of their skins for a while, to perceive and act in the capacity of just b eing h uman. W hites $m$ ust $c$ onsider the c osts t o their o wn $\mathrm{p}$ syches a nd mental $\mathrm{w}$ ell $\mathrm{b}$ eing $\mathrm{i}$ nherent in the imposition of European institutions upon Africa and peoples of African descent wherever they are found.
} 
University, Katherine B ankole-Medina, b elieves that A sante is taking A frican Diaspora studies to new levels with Afrocentricity's emphasis on matters of race, rhetoric and identity. ${ }^{51}$ She felt that Asante was moving in directions that informed African peoples worldwide in areas that went far beyond the rudimentary constructs of race and power.

\section{Tentative Conclusions}

Some tentative conclusions may be drawn, and these are that despite their gradual process of mestizaje (miscegenation) and a di minishing of s ome of their cultural traditions, the A froZulians he ld on $\mathrm{t}$ ot heir Imbangala e thos or spirit. I $\mathrm{n}$ addition $\mathrm{t}$ o self-identification as descendants of $t$ he $\mathrm{A}$ ngolan $\mathrm{bl}$ acks $\mathrm{b}$ rought $\mathrm{o}$ ver $\mathrm{b}$ y $\mathrm{J}$ ean $\mathrm{d}$ e $\mathrm{C}$ hourio, $\mathrm{t}$ hey a re cautious, mysterious and reserved toward outsiders. Even until the present, they managed to maintain a sense of a utonomy, a uthority a nd control in the $\mathrm{m}$ aking o $\mathrm{f}$ f ormal and i nformal de cisions regarding their rights, $d$ uties, pr ivileges, hous ing, 1 and us e and ot her i ssues throughout their history. In other words, as active social actors on the stage of history, they have maintained their own e thnic identity and ha ve continued to interpret, c onstruct, r eproduce a nd transform their experiences $w$ ithin the context of the Trans-Atlantic w orld. The case study elaborated in this work al so r eveals that an $\mathrm{y}$ ap proach to the A fro-Zulian community m ust include more than a mere collection and $\mathrm{c}$ ataloging of $\mathrm{m}$ iscellaneous data. It $\mathrm{m}$ ust be $\mathrm{g}$ leaned for the pur pose of synthesizing and reconstructing a New Africa in the northwest of Venezuela.

\footnotetext{
${ }^{51}$ Molefi Asante, Race, Rhetoric and Identity: The Architecton of the Soul (Amherst, New York: Humanity Books, 2005), jacket review by Katherine Bankole (nee)-Medina.
} 


\section{CHAPTER TWO \\ JEAN DE CHOURIO E ITURBIDE}

\section{Introduction}

This ch apter ex amines the ear ly through midlife of $\mathrm{J}$ ean de $\mathrm{C}$ hourio e I turbide in the context of the late seventeenth and early eighteenth century Trans-Atlantic world. Chourio was born in the French Basque country, and heavily influenced by both of these European cultures. His Basque roots provided him with a worldwide fraternity and network of fellow countrymen. Wherever Basques, whether from the French or Spanish side of the Pyrenees, congregated, they did not hesitate to assist each other in advancing their mutual objectives. The Basques are also a people intimately connected with the sea; and this, too, provided an impetus in career selection

for the young Chourio. Additionally, his French origins allowed him access to the corridors of power in Europe and beyond. Throughout his youth, Chourio accompanied his father on various diplomatic $\mathrm{m}$ issions throughout E urope, no doub $\mathrm{t} \mathrm{m}$ aking $\mathrm{m}$ any valuable contacts that would assist him later in life. From the French, he also garnered a more worldly education and attitude toward A fricans and European policies geared toward them. Acting initially as an agent of the French $\mathrm{R}$ oyal $\mathrm{G}$ uinea $\mathrm{T}$ rading $\mathrm{C}$ ompany, a nd $\mathrm{l}$ ater a s a $\mathrm{n}$ i ndependent businessman, $\mathrm{C}$ hourio tenaciously hung on to the margins of a thriving outpost of Western European society developing in the Caribbean and circum-Caribbean.

It was a society infused with a conglomeration of Western European influences. A part from the B asque and French, C hourio pa rticipated in s undry s muggling ope rations unde $\mathrm{r}$ the auspices of the Dutch authorities in the Netherlands Antilles. From a base in Curaçao, Chourio plied s loops all a long the coast of the S panish Main, from Cartagena to La Guaira, providing manpower and materials to the de veloping colonies of the region in exchange for their cacao 
harvests. Keeping in mind that the early eighteenth century Trans-Atlantic world was governed by the norms of mercantilism, each European power established trade monopolies over all of the commercial activities in their respective colonies. Therefore, throughout the Spanish realm, that included Venezuela, the British, Dutch, French, and Portuguese were to be excluded from buying or selling activities. Only commerce between Spain, the mother country, and her own colonies, was pe rmitted. $\mathrm{T}$ his $\mathrm{p}$ olicy, of $\mathrm{c}$ ourse, 1 ed to $\mathrm{t}$ he de velopment of $\mathrm{i}$ llegal $\mathrm{t}$ rade $\mathrm{w}$ ith ot her European c ountries. B ecause $t$ he $\mathrm{S}$ panish i mposed hi gh por $\mathrm{t} t$ axes, a nd be cause $\mathrm{S}$ panish manufactured goods were expensive anyway, being compounded by long trans-Atlantic voyages and the cost of abating pirate activity, it was more advantageous for Spain's American colonists to simply do business with the British, French or Dutch then operating in the Caribbean. These foreign pow ers c ould of fer a $\mathrm{n}$ e laborate va riety of pr oducts a $\mathrm{t} l$ ower pr ices $t$ han e ither $\mathrm{t}$ he Spanish peninsulares or even the colonists themselves.

Meanwhile, especially after the signing of the Treaty of Utrecht in 1713, Chourio had to deal w ith ne ar c onstant B ritish a ttempts to s hut him out of Caribbean a nd C ircum-Caribbean commercial ventures of all types. Other Europeans he encountered were the Germans, who had long controlled a spects of the V enezuelan s lave trade th rough the W elser family; the Italians, who supplied the majority of the missionaries for the Capuchin missions in both Angola and the Spanish American colonies; the Portuguese, who monopolized the source of black slave labor on the African continent; and the Spanish, whose new king of French ancestry would walk a tight rope in trying to placate the British while still hanging on to men like Chourio, who made the continued development and success of the Spanish American colonies a reality. ${ }^{1}$ It was also a

\footnotetext{
${ }^{1}$ Federico B rito F igueroa, Estructura Económica de Venezuela Colonial (Caracas: U niversidad C entral d e Venezuela, 1963), 99. The presence of the Welser family in Venezuela has its origin in an accord signed between the Augsburg ba nking house a nd the Spanish C rown on $27 \mathrm{M}$ arch $1528 \mathrm{f}$ or the de velopment, settlement a nd governance of the Province of Venezuela. This accord obligated the German Welser family to establish at least two
} 
society heavily impacted by both an African and Native American ethos, regardless of whether or not the European colonists or Creoles wanted to recognize this fact. Thus was the world of Juan de Chourio e Iturbide.

\section{Chourio and Venezuela}

Chourio chose a life that some considered "infamous."” Being of French Basque origin, he was always viewed with suspicion outside of his own ethnic circle. He and others involved in the ex tra-legal $t$ rade $w$ ith $V$ enezuela, or iginating $\mathrm{m}$ ostly from $\mathrm{t}$ he $\mathrm{i}$ sland of $\mathrm{C}$ uraçao, were attributed a $\mathrm{n}$ in famy and in ordinate s ymbolic attention a s a direct result of th eir a ssociation, physical or id eational, with the ma ssive c ultural, e conomic and pol itical t ransitions that t ook place in ear ly ei ghteenth cen tury $\mathrm{C}$ aribbean $\mathrm{s}$ ociety. $\mathrm{M}$ en 1 ike $\mathrm{C}$ hourio $\mathrm{w}$ ere $\mathrm{v}$ iewed as the harbingers of $\mathrm{c}$ hange, and a change that not $\mathrm{m}$ any were $\mathrm{w}$ illing to a ccept. $\mathrm{B}$ ecause $\mathrm{C}$ hourio operated on the edges of socially accepted behavior and space, he fell subject to ritualized social interactions and spatial segregation, especially by the British and Spanish colonial authorities. It is ironic that while these authorities reviled Chourio and others involved in the extra-legal trade, the very existence of their societies depended on $t$ hem for ne eded supplies and the de fense of emerging European New World colonies.

As not ed i n $\mathrm{C}$ hapter One, $\mathrm{C}$ hourio be gan hi s c areer i $\mathrm{n} t$ he e xtra-legal tr ade $\mathrm{w}$ ith Venezuela from an of fice on $t$ he i sland of Curaçao, whence he was under suspicion by Dutch colonial authorities as being an agent of the French. Hence he was eventually expelled from the

cities within two years of their arrival, construct at least three forts, and arm four ships of the Spanish armada. It also allowed for the transport to Venezuela of $300 \mathrm{~S}$ panish men and $50 \mathrm{G}$ erman miners. It ga ve them the right to enslave any Native Americans they encountered as well as to import 4,000 African slaves to the colony. This was the first such asiento, or charter to import A frican slaves, granted by the Spanish Crown. The first of the Welsers arrived on the Venezuelan Coro Peninsula on 28 February 1529 to begin these endeavors. However, the exclusivity of the asiento did not last, as within one year others from Santo Domingo and Spain were importing African slaves to Venezuela.

${ }^{2}$ Anton Blok, Honour and Violence (Cambridge: Polity Press, 2001), 44-68. 
island a nd had to s eek the pa tronage of the S panish king, through r oyal de crees, in or der to operate $\mathrm{d}$ irectly from $\mathrm{t}$ he $\mathrm{S}$ outh A merican $\mathrm{m}$ ainland as a $\mathrm{d}$ uly-appointed $\mathrm{r}$ epresentative of a recognized French trading concern. But before making this tentative leap into legality, it could not be denied that Chourio had be en a broker of this extra-legal trade between Dutch Curaçao and $\mathrm{S}$ panish $\mathrm{V}$ enezuela i $\mathrm{n}$ he e arly e ighteenth $\mathrm{c}$ entury, a nd t herefore hi $\mathrm{s} \mathrm{w}$ as $\mathrm{c}$ ontinually considered $\mathrm{m}$ ore da ngerous $\mathrm{t}$ han ot hers i $\mathrm{n}$ a $\mathrm{n}$ " institutionalized, s ociety-wide s ystem o $\mathrm{f}$ transgression." ${ }^{3}$

Essentially, Chourio was a smuggler, and a very good one. B ut smuggling in Europe's New W orld colonies entailed the direct violation of sundry mercantile trade restrictions, Crown territorial boundaries, and often the ecclesiastical divides imposed between faithful adherents and perceived heretics (i.e. the $\mathrm{C}$ atholic Chourio do ing business w ith the Protestant $\mathrm{D}$ utch). T hus, intermediaries and smugglers like Chourio, who facilitated exchanges across imperial bounds in the e ighteenth $\mathrm{c}$ entury Caribbean a nd c ircum-Caribbean, $\mathrm{pl}$ ayed a critical $\mathrm{r}$ ole in $\mathrm{n}$ ot o nly connecting A merican c olonies w ith e ach ot her, but a lso i n e stablishing ne w T rans-Atlantic circuits of trade with European and African systems of production and consumption, thus forging New World commercial and, as a by-product, cultural, linguistic and political linkages.

Spanish co lonial b ureaucrats an $\mathrm{d} \mathrm{m}$ ilitary o fficers i $\mathrm{n}$ ei ghteenth cen tury $\mathrm{V}$ enezuela tended, on the other hand, to seriously overestimate the threat that Chourio and other smugglers posed to C rown-sanctioned trade and social stabilization. C hourio and other brokers of extralegal $\mathrm{t}$ rade w ere k nown i n ei ghteenth cen tury New G ranada (Colombia) an d V enezuela as prácticos, plácticos or peritos. These smugglers enjoyed a special attention within an extensive

\footnotetext{
${ }^{3}$ Cohen, "Role of the Práctico," 2.
} 
but infamous system of exchange that also included the trafficking in human cargo. ${ }^{4}$ Basically, New $\mathrm{W}$ orld $\mathrm{s}$ muggling dur ing $\mathrm{t}$ he e arly e ighteenth $\mathrm{c}$ entury pi tted $\mathrm{C}$ rown de signs $\mathrm{f}$ or $\mathrm{t}$ he mercantile integration of the metropole's colonies against local desires and practices. ${ }^{5}$

Smuggling $\mathrm{w}$ as $\mathrm{w}$ idespread $\mathrm{t}$ hroughout $\mathrm{t}$ he e ntire $\mathrm{C}$ aribbean and c ircum-Caribbean regions from the late s eventeenth through the eighteenth c enturies. A nd a ccording to C ohen, there were some places, especially the periphery islands and mainland regions that bordered the sea, where "extra-legal trade represented a g reater portion of commercial activity than the trade conducted in accord with imperial mercantile policies." ${ }^{6}$ Some European powers, like Holland, established c olonies like C uracao and $\mathrm{S}$ aint E ustatius, whence the infraction of ot her colonial nations' commercial restrictions could be carried out on a regular and profitable basis. Chourio must have been keenly aware of this fact, positioning himself nicely to gain a foothold in the region and claim his slice of the pie.

The Dutch with whom Chourio dealt had two significant colonies in the Caribbean: the islands of Curaçao, off the coast of Venezuela, and Saint Eustatius. ${ }^{7}$ Curaçao was captured from the Spanish in 1634 and was converted into a staging area for early seventeenth century raiding parties on the S panish S outh A merican mainland. By the end of the seventeenth century, the Dutch W est Indian C ompany succeeded in transforming the island of Curaçao into i ts hub of Caribbean activities, the West Indian counterpart to Holland's prized city of Amsterdam, where

\footnotetext{
${ }^{4}$ For works done on prácticos in the c olonial S panish Caribbean and c ircum-Caribbean, s ee Lance Grahn, The Political Economy of Smuggling: Regional Informal Economies in Early Bourbon New Granada (Boulder: West View Press, 1977); Aizpurua, Curazao y la Costa de Caracas; Wim Klooster, Illicit Riches: Dutch Trade in the Caribbean, 1648-1795 (Leiden: KITLV Press, 1998); and Hector R. Feliciano Ramos, El contrabando inglés en el Caribe y el Golfo de México, 1748-1778 (Sevilla: Publicaciones de la Excma. Diputación Provincial de Sevilla, 1990).

${ }^{5}$ Pieter Emmer, The Dutch in the Atlantic Economy, 1580-1880: Trade, Slavery and Emancipation (Brookfield, Vermont: Ashgate Publishing, 1998), 16-17.

${ }^{6}$ Cohen, "Role of the Práctico," 3.

${ }^{7}$ St. E ustatius or S tatia, is located in the northeastern Caribbean, 150 miles e ast of P uerto R ico (latitude 17.00, longitude 63.04), 90 miles east of St. Croix, 38 miles south of St. Maarten and 17 miles southeast of Saba. Statia State Tourist Office, http://www.statiatourism.com/map.html (17 August 2009).
} 
Chourio's father ha d w orked a s a di plomat. Most 1 ikely, it w as the pol itical i nfluence of Chourio's father which allowed Jean Chourio e Iturbide to begin his operations on the island of Curaçao. According to Rupert:

In early 1708 a dapper French gentleman (Jean Chourio) arrived in Willemstad (the capital of Curaçao) from La Guaira, Venezuela, requesting an audience with the Governor. The son of the Spanish consul in Amsterdam, he represented the French asiento (trading concern) in Cartagena, Colombia. Jean Chourio informed Governor Beck that his asiento commission, signed by Spain's Philip V, granted him the right to purchase slaves in Jamaica and Curaçao for the colonies of the Spanish American mainland. A lthough the Dutch and French were at war, such examples of 'peace beyond the line' were typical of the times. It would be highly profitable, he suggested, if the trade included other activities that were needed on the mainland; this open invitation to contraband smuggling $m$ et with imme diate interest from the Governor and local merchants. ${ }^{8}$

Note how Governor Beck and other Curaçao merchants demonstrated a willingness to engage in contraband trade with Chourio, de spite the fact that France and Holland were technically at a state of war.

There were, to be more specific, two significant commercial circuits that met at Curaçao. ${ }^{9}$ First, there w as the Trans-Atlantic trade be tween Holland (United P rovinces) and her (Dutch) colonies in the Caribbean. This was known among the Dutch as the grote vaart. Second, there was the transit trade within the Caribbean, circum-Caribbean and North America, known among the Dutch as the kleine vaart. The kleine vaart joined the island with some points along Atlantic North America, the Greater Antilles, the Windward and Leeward Islands, and its most important link, that being the routes to and from Venezuela. ${ }^{10}$ Primarily, Dutch ship captains, merchants and their representatives would cruise the Venezuelan coast. Sometimes Venezuelan merchants or planters would go directly to Curaçao to trade or make arrangements for future transactions.

\footnotetext{
${ }^{8}$ Rupert, Roots of Our Future, http://books.caribseek.com/Curacao/Commercial_History_of_Curacao/profiles/jeanchourio.shtml.

${ }^{9}$ Ibid.

${ }^{10}$ Ramón A izpurua, Temas de historia colonial de Venezuela y del Caribe (Caracas: Universidad C entral d e Venezuela, 1966), 16-17.
} 
Sloops, ${ }^{11}$ like C hourio's, w ould s ail out $\mathrm{f}$ rom Willemstad $t$ hroughout $t$ he year bound $f$ or Venezuela; and this traffic would more than double during times of the cacao harvest. ${ }^{12}$

Almost all of Venezuela's colonial e conomy was based on the export of cacao. ${ }^{13}$ The output of ot her a gricultural e xports, 1 ike $t$ obacco or w heat, $w$ as 1 iterally dw arfed b y t he tremendous ha rvest of cacao. F rom the $\mathrm{m}$ id-seventeenth century forward, $\mathrm{c}$ acao dom inated Venezuela's agricultural landscape, or ienting the colony's e conomy to a literal single product export status. This cacao production was geared almost exclusively to meeting the demands of external markets. The cacao plantations were established all along the Venezuelan coastal region [litoral], in Choroní, Ocumare, Chuao and Turiamo; in the valleys of Caucagua, Capaya, Curiepe and Guapo; as well as in the cities of Barquisimeto, Trujillo and Mérida. The cacao harvest took place $t$ wice a year, in J une an d December. It was dur ing these months, and the w eeks that followed them, that the s loops w ould $\mathrm{j}$ am $\mathrm{V}$ enezuela's por ts a nd i nlets $\mathrm{c}$ lose $\mathrm{t}$ o t he $\mathrm{c}$ oastal valleys to load up on the cacao exports. ${ }^{14}$

Ships arriving in Venezuela usually followed two main itineraries. The first was a stay in Venezuela that included calls at numerous ports. This could last anywhere from two w eeks to two months. Second, there were shorter, but more direct trips, to specific destinations closer to

\footnotetext{
${ }^{11}$ Captain Jean Chourio e Iturbide commanded many sloops in the Caribbean. Having a length of 30 to 60 feet and a top speed of over $10 \mathrm{knots}$, a crew of 20 to 70 men could easily maneuver this father of today's sailing yacht for quick in-and-out surprise attacks, avoiding broadsides and outrunning pursuit. With the sloop weighing as much as 100 tons and being armed with as many as 15 cannons, its draft was still very shallow at eight feet and allowed it to find $r$ efuge $i \mathrm{n} s$ hallower waters $f$ ar $b$ eyond $t$ he $r$ each o $f$ an $y$ warship. $T$ his al so was $t$ he $r$ eason $t$ hat $t$ hose commissioned to hunt pirates often chose the sloop to gain access to their hiding spots. Pirates, the Scourge of the Spanish Main, piratesofthecaribbeansea.com/ships2.html, (17 August 2009).

${ }^{12}$ Eugenio $\mathrm{P}$ iñero, The Town of San Felipe and Colonial Cacao Economies (Philadelphia: $\mathrm{T}$ he A merican Philosophical Society, 1994), 113-138.

13 Alan D avidson a nd T om J aine, Oxford Companion to Food (Oxford: O xford U niversity P ress, 2006), 178. "Cacao is the usual term for the tree and for its seeds (misleadingly, 'cocoa' has sometimes been used in English). A complex process of roasting, fermenting, and grinding turns these seeds into chocolate."

${ }^{14}$ Rafael Estrada, et al, Estudios Sociales (Caracas: Ediciones Co-Bo, 1997), 47.
} 
the Dutch islands of Aruba, Curacao, and Bonaire. ${ }^{15}$ These more direct trips were destined for the $\mathrm{V}$ enezuelan $\mathrm{C}$ oro $\mathrm{P}$ eninsula, not $\mathrm{f}$ ar $\mathrm{from}$ a nd s outh of $\mathrm{A}$ ruba, or the $\mathrm{D}$ utch e nclave of Tucacas, ${ }^{16}$ on the Venezuelan coast halfway between Coro in the west and Caracas in the east, and s outh of $\mathrm{C}$ uraçao and $\mathrm{B}$ onaire. At times a s tay in Tucacas $\mathrm{m}$ ight result in a $\mathrm{n}$ e xtended layover, depending on the presence of Spanish corsairs in the area or weather conditions at sea.

The $\mathrm{c}$ rews of $\mathrm{t}$ he $\mathrm{s}$ loops e manating $\mathrm{f}$ rom $\mathrm{C}$ uraçao a nd bound $\mathrm{f}$ or $\mathrm{V}$ enezuela $\mathrm{w}$ ere composed of a captain, sailors, and a merchant or his representative. ${ }^{17}$ In the case of Chourio, he occupied the dual post of captain and merchant. Being viewed suspiciously by the Dutch, he no doubt $\mathrm{w}$ anted to take pe rsonal $\mathrm{c}$ harge of the $\mathrm{c}$ argo, from the po int of its pick-up all the w ay through its unlading and ultimate purchase. ${ }^{18}$

The sailors were mostly free blacks and slaves from Willemstad, recruited by the captain or $\mathrm{m}$ erchant a nd hi red out $\mathrm{b} y \mathrm{t}$ heir ow ners. $\mathrm{K}$ looster $\mathrm{m}$ aintains $\mathrm{t}$ hat $\mathrm{f}$ ree $\mathrm{bl}$ ack $\mathrm{s}$ ailors $\mathrm{w}$ ere usually hired for a single journey, and that when the ship returned to Willemstad the crews were dispersed w ith e ach i ndividual g oing hi s ow $\mathrm{n} w$ ay, s eeking t he ne xt opportunity t o pl y the

\footnotetext{
${ }^{15}$ The Netherlands A ntilles [Dutch: Nederlandse Antillen], previously known as the Netherlands W est Indies or Dutch Antilles/West Indies, is part of the Lesser Antilles and consists of two groups of islands in the Caribbean Sea: Curaçao and Bonaire, just off the Venezuelan coast, and Sint Eustatius, Saba and Sint Maarten, located southeast of the Virgin Islands. The islands form an autonomous part of the Kingdom of the Netherlands. The islands' economy today depends m ostly u pon tourism, i nternational financial s ervices, i nternational co mmerce an $\mathrm{d} s$ hipping an $\mathrm{d}$ petroleum. The Central Government of the Netherlands Antilles, http://www.gov.an/ (17 August 2009). In 1636, near the culmination of the Eighty Years' War between Spain and Holland, the Dutch took possession of Aruba and remained in c ontrol f or $\mathrm{n}$ early $\mathrm{t}$ wo $\mathrm{c}$ enturies. I $\mathrm{n} 1805$, d uring th e $\mathrm{N}$ apoleonic $\mathrm{W}$ ars, th e B ritish br iefly t ook possession of the island, but it was returned to Dutch control in 1816. Today, Aruba remains a part of the Kingdom of the Netherlands, but functions independently with its own government apparatus. The Official Tourism Website of Aruba, http://www.aruba.com/ExploretheIsland/IslandFacts/history.aspx (17 August 2009).

${ }_{16}$ Celestino A ndrés A rauz Monfante, El contrabando holandés en el Caribe durante la primera mitad del siglo XVIII (Caracas: Biblioteca de la Academia Nacional de la Historia, 1984), 65-66, 198-201. Early in the eighteenth century, merchants from Curaçao established an outpost in Tucacas toward the western frontier of the Province of Venezuela. H ere they constructed warehouses, residences, and even a s ynagogue. S panish colonial authorities in Caracas sent several military expeditions against the Dutch settlement, only so see it rebuilt and reoccupied not soon after they withdrew.

${ }^{17}$ Cohen, "Role of the Práctico," 4.

${ }^{18}$ Cohen claims that he was unable to find a B asque, European or white Creole práctico from the mainland of Venezuela, so this dissertation at least confirms the existence of one in Jean de Chourio. Ibid., 15.
} 
Venezuelan coast. ${ }^{19}$ While Chourio was involved for a time in the slave trade, it is clear that his primary bus iness concern $\mathrm{w}$ as c acao, cloth and other non-human m erchandise. $\mathrm{T}$ he hi storical record with regard to the práctico indicates that Chourio m ost likely vi ewed A fricans w ith a more pragmatic eye.

Figure 2.1: Jean de Chourio sailed on a sloop like this one.

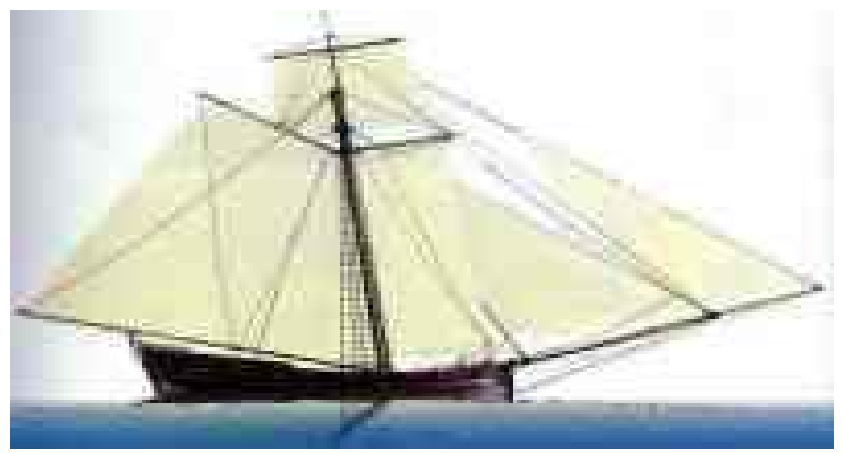

Source: piratesofthecaribbeansea.com/ships2.html

\section{The World that Formed Jean de Chourio}

The $\mathrm{m}$ eans $\mathrm{b} \mathrm{y}$ w hich $\mathrm{C}$ hourio a rrived in $\mathrm{t}$ he $\mathrm{C}$ aribbean conducting $\mathrm{t}$ rade $\mathrm{w}$ ith s undry European colonies ha d a l ot to do w ith his up bringing in the B asque country. $\mathrm{T}$ his s ection explores the Basque region that helped shape the younger Juan de Chourio's life and out look. The saga begins in the Basque village of Azcaín, where Juan de Chourio, the son of Don Juan de Chourio and Doña Estafanía e Itrubide, was born in 1676. During that time, Azcaín was a part of the Spanish kingdom of Navarra. ${ }^{20}$ Today, how ever, it falls within the predominantly Basque jurisdiction of the region of the Pyrénées-Atlantiques, and the French province of Aquitaine. By heading due s outh, one $\mathrm{c}$ an find m ountain pa sses through the Pyrenees, leading to the B aztan valley, where the young $\mathrm{C}$ hourio s pent his formative years $\mathrm{w}$ ith his $\mathrm{p}$ arents in the Villa $\mathrm{de}$

\footnotetext{
${ }^{19}$ Klooster, Illicit Riches, 135.

${ }^{20}$ Alcaldia Rosario de Períja: Historia: Su fundador, http://alcaldiarosariodeperija.com.ve (27 April 2009).
} 
Bisadea. $^{21}$ Writing about $\mathrm{t}$ he $\mathrm{f}$ amous $\mathrm{f}$ amilies a nd genealogies $\mathrm{i} \mathrm{nt}$ his $\mathrm{B}$ asque $\mathrm{r}$ egion encompassing both sides of the contemporary French and Spanish border, Caro Baroja stated that from the recovery of a rchives from various courts and viceroyalties, we s ee that Navarra had, overall, a strong and prosperous presence in the Spanish colonies. ${ }^{22}$ We also see that the Navarre colonists were especially favored by Madrid, by reason of royal of ficials a ppointed from, and trade concessions granted to, them. ${ }^{23}$ The solidarity that existed between Navarre families was no longer an idea found just in the writings of the seventeenth century, but also at the beginning of the reign of Philip V, in the emergence of a dialogue between Basques and Castilians in Peru, where the Castilians blamed the French-Basques in territories in America of representing French interests, a nd be ing pr otected b y S panish-Basques. B ut $\mathrm{t}$ his Basque/Navarre s olidarity w as clearly $b$ ased on s trong kindred and border ties. O thers today in the A mericas s ay that many Castilian names are really of French Navarre origin, because the largest part of the kingdom of Navarra was in France. ${ }^{24}$ It should also be pointed out that in the Basque regions of France, the name Chourio is quite common, but spelled "Xurio." 25 Also, the Iturbide family ancestral town

\footnotetext{
${ }^{21}$ Ibid.

22 Julio Caro Baroja, Hora Navarra del XVIII (Pamplona, España: Editorial Gómez, 1969), 19.

${ }^{23}$ Government of Navarra, http://www.navarra.es/home en/Navarra/Asi+es+Navarra/Autogobierno/El+Reino+ de+Navarra.htm (27 April 2009). In accordance with this official Navarra website, government jurisdictions in this region may be broken do wn into the following pe riods: 1) F rom the $\mathrm{N}$ inth Century to $1515, \mathrm{~N}$ avarra was an independent kingdom; 2) From 1515 to 1839, Navarra was a kingdom annexed to the Spanish crown, but except for the monarchy, maintained its own institutions; 3) 1841-1982, Navarra was a Spanish province, with administrative and fiscal autonomy; and 4) 1982 to the present day, in accordance with the Constitution of 1978 a nd the Ley de Reintegración y Amejoramineto del Fuero (the official name given to Navarra's own statute of autonomy), Navarra is a Comunidad Foral within the framework of Spain's status as a nation of autonomous communities. This means that it preserves its own democratic institutions and a high degree of self-government. Therefore, in considering the case of Chourio or other Navarre of the $18^{\text {th }}$ century, it must be noted that the sovereignty of Spain's Philip V held sway.

${ }^{24}$ Caro Baroja, Hora Navarra, 13 The author examines people, families, businesses and ideas important to the formation of $18 \mathrm{th}$ century $\mathrm{S}$ pain, a nd e xplains ho w the influence of $\mathrm{F}$ rance e xtended throughout $\mathrm{t}$ he whole of Navarra, on by sides of the Pyrenees.

${ }^{25}$ Hector I glesias, http://hal.archives-ouvertes.fr/docs/00/33/98/60/PDF/Patronymes_d_origine_basque.pdf (27 April 2009). Also, see Jaime de Querexeta, Diccionario Onomastico y Heraldico Vasco, (Bilbao: Biblioteca de la Gran Enciclopedia Vasca, 1970), Tomo I, 8-11; (1971), Tomo II, 179; (1972), Tomo III, 163. Tomo I provides a list of abbreviations employed and a guide for interpreting the data pertinent to the Basque family names listed. Tomo II states, "CHOURIO (Xurio).-1. En Sara (Laburdi), en 1609. 2. Var. De Churio" (179), and "CHURIO
} 
of Irisarri i s pr esently located on $\mathrm{t}$ he $\mathrm{F}$ rench side of $\mathrm{t}$ he $\mathrm{P}$ yrenees a nd i s know $\mathrm{n} t$ here a $\mathrm{s}$ "Irissarry," ${ }^{26}$ not far from the place of Jean de Chourio's birth.

There remains 1 ittle doubt, therefore, that $\mathrm{F}$ rance he ld a $\mathrm{n}$ ove rwhelming $\mathrm{c}$ ultural s way throughout Navarra and all the Basque lands. Adds Caro Baroja, "Whether it was Colbert on the politics of Carlos II or Felipe V, or just modes of thinking about economics, religion or general topics, in the eighteenth century Kingdom of Navarra there was a definite orientation to all things French. T he influence of F rance was pr evalent, exercising both vi sible and i nvisible lines of force." 27

Prior $t \mathrm{o}$ the s igning of the $\mathrm{T}$ reaty of $\mathrm{U}$ trecht, Chourio $\mathrm{t}$ ook a dvantage of $\mathrm{h}$ is $\mathrm{F}$ rench ancestry at every occasion. Alberto Santana Ezkerra, a professor and director of Basque Studies at Boise State University in Idaho, has stated that, "the Iturbides were one of the most powerful families in the $v$ alley of B aztan (Nafarroa): $b$ ankers, $t$ raders an $d t$ he leading $m$ embers of $a$ selected group of navarrese families...."28 He further explains that s ince J uan de C hourio e Iturbide shared a F rench and Basque ancestry, he came from a family branch that at the end of the seventeenth century was well settled in the town of Irisarri (Nafarroa Beherea), where there is still a farmhouse c alled Iturbide. $\mathrm{S}$ antana Ezkerra adds that since $\mathrm{J}$ uan de $\mathrm{C}$ hourio $\mathrm{w}$ as a prominent Basque resident of colonial Venezuela, he was intimately involved in the foundation of the Real Compañía Guipuzcoana de Caracas. This company was established in 1728 to give

(Txurio).-1. En Ataun (G), en 1383. 2. Der. De Churí, con el suf. Loc. -tegi, leguar de, vivienda, casa de” (180). Almost the entire right side column in Tomo III provides an entry for ITURBIDE, where from one branch sprang the Mexican liberator and emperor in 1822, Augustín de Iturbide y Aranburu (163).

${ }^{26}$ Irissarry, http://maps.google.com/maps (16 August 2009). Also note the comments of Alberto Santana Ezkerra, Boise State University, Idaho, later in this chapter regarding this Iturbide family town.

${ }^{27}$ Caro Baroja, Hora Navarra, 13.

${ }^{28}$ Alberto Santana Ezkerra to Patty Miller, Executive Director of Basque Museum and Cultural Center at Boise, Idaho, 25 March 2009. Forwarded e-mail in possession of author. 
some legal s anction to the increasing volume of primarily Basque-conducted trade which had proliferated in Venezuela since the Treaty of Utrecht. ${ }^{29}$

As for the life of the average Basque male, residing on either the French or Spanish side of the Pyrenees Mountains and living at the end of the seventeenth or beginning of the eighteenth century, it was very hard. F or the most part, life was drudgery. The typical Basque male was trying to e ke o ut a s urvival e xistence for himself a nd h is family by farming in rocky s oil or fishing off the coastal areas. B ut the young Juan de Chourio was anything but mediocre. H e could s ee what w as g oing on a round hi m, a nd he qui ckly realized that there w ere onl y four possibilities for escaping the grinding cycles of poverty that were encroaching upon him and the Basque nation as a whole: the church, commerce, the government bureaucracy, or the military (land and/or sea forces). ${ }^{30}$

Within Chourio's own family, many had attained powerful influence in European society through ecclesiastical careers. T he t own of C hourio's bi rth, A scain, was a f ocal poi nt f or religious zealots in the burning of suspected witches. In 1610, a priest of approximately seventy years of age by the name of Arguibel was burned at the stake for his alleged failure to maintain the pur ity of $\mathrm{R}$ oman $\mathrm{C}$ atholic doc trine i n hi s s peech a nd w ritings. ${ }^{31}$ He s upposedly w as a practitioner of varied forms of Basque magic and w itchcraft, and mix ed these a dministrations with his local service as a parish cleric. In that old world of beliefs, all things and people, and their respective images, were united by a magical power known by the Basques as adur. If you had a sufficient faith in the adur, then whatever was done to the image was bound to happen to the thing or person it represented. This was something akin to African and Caribbean Voodoo.

\footnotetext{
${ }^{29}$ Ibid.

${ }^{30}$ Caro Baroja, Hora Navarra, 29.

31 J.-B. Daranatz, Traductions Basques de la “Philothée,” http://hedatuz.euskomedia.org/167/1/16056064.pdf (27 April 2009).
} 
And e ven if an e ducated B asque $h$ ad his doubt s a bout this fetish s ystem, he w ould m aintain silence a bout it. T here is a old Basque saying that goes, "Direnik, es da sinistu behar; ez direla, es da esan behar." Translated, this means that: “If you don't believe they exist [dark spiritual forces], don't s ay they don't exist." S o, in essence, you were damned if you did not acknowledge the ex istence of magic, and equally condemned if you were seen as too eager to believe it. $^{32}$

The young Chourio was surrounded by this religious hysteria. Perhaps he recognized that the e vil de eds a ttributed to witches w ere co mpletely fictitious. A fter al l, he w as $\mathrm{r}$ aised in a family w ith noble connections to both the F rench and S panish C rowns, and 1 iterate in several languages. S undry a ccounts be came jumbled in the witch trials as w ell, with innocent people being accused of things only read about in books on witchcraft. The accused were then tortured until they c onfessed. And then there w ere accusations br ought a bout $\mathrm{b} y$ di sgruntled fellow villagers with quarrels to settle, or even by prompted children. In addition, natural disasters that ruined crops or caused flood or wind damage had to be explained away in some fashion, and in an age without meteorological testing equipment of any accuracy, it was quite convenient to look for scapegoats. ${ }^{33}$

Nor can one dismiss the possible survival of ancient pre-Christian Basque rites, which the Roman Catholic Church had failed to suppress during the Inquisition and that had managed to continue $\mathrm{f}$ or a $1 \mathrm{t}$ hat $\mathrm{t}$ ime. In Basque $\mathrm{c}$ ulture a $\mathrm{w}$ itch, or $\mathrm{s}$ orgin, $\mathrm{c}$ an $\mathrm{r}$ efer $\mathrm{t} \mathrm{o} \mathrm{t}$ wo $\mathrm{t}$ ypes of individuals. $\mathrm{F}$ irst, there are $\mathrm{m}$ ythological be ings with $\mathrm{s}$ pecial pow ers that a ppear in c ountless folk tales; and secondly, there are those persons who conclude pacts with the devil, participate in witches' sabbaths, and curse people by inflicting the "evil eye" upon them. Nevertheless, many

\footnotetext{
${ }^{32}$ Juan Carlos Etxegoien, Country of the Basques (Pamplona: XAMAR, 2001), 50-51.

${ }^{33}$ Ibid.
} 
of $t$ he i ndividuals accu sed o f $w$ itchcraft $w$ ere eccl esiastical o fficials, 1 ike $t$ he $p$ oor $F$ ather Arguibel, or seonak (church wardens, lay w orkers, etc.). ${ }^{34}$ As far as an y similarities between these earlier Basque beliefs and the tenets of not a few African animist and fetish sects adopted and modified by blacks in the Americas, more will be written in a subsequent chapter.

Chourio, it should be recognized, also had relatives who served in the priesthood. F or example, the church registry at Azcain indicates that on $4 \mathrm{~J}$ anuary 1690, Father Axular Pierre de Chourio accepted an ecclesiastical nomination to the cathedral at Bayonne. ${ }^{35}$ The young Juan de Chourio, upon vi siting this relative at the cathedral on the French coast, may have been enticed by the pomp and splendor of the majestic edifice, but upon further recollection, decided that the ecclesiastical life was one too full of hypocrisy. He may have also concluded that his chances of living a long and happy life would be better enhanced living further out from this madness, as clerics, more than most people, ended up a s the targets of witch hunters. A s an educated man, Chourio c ould a ccept a nd a ppreciate the ba sic tenets of R oman C atholicism, but m ost 1 ikely could not br ook religious s uperstition m asquerading as truth. ${ }^{36}$ According to E txegoien, the witch hunts that spread throughout Europe especially affected the Basque country. According to this Basque historian: “There are more than a few who think they (the witch hunts) constituted an at tack on Euskal Herria, (the Basque lands) since m ost of the w itch trials t ook place after Nafarroa was conquered by Castile." ${ }^{37}$

In all probability, Chourio saw it as a land and power grab by $\mathrm{C}$ astile, but he had the common s ense t o k eep his opi nions to hi mself a nd to c onsider ot her avenues for $\mathrm{m}$ aking a fortune, or at least making his way in life.

\footnotetext{
${ }^{34}$ Ibid.

${ }^{35} \mathrm{http} / / /$ hedatuz.euskomedia.org/167/1/16056064.pdf (27 April 2009).

${ }^{36}$ See Appendix C for some of the Roman Catholic motivations that may have inspired Juan de Chourio.

${ }^{37}$ Etxegoien, The Country of the Basques, 51.
} 
On the other hand, the siren call of the sea was tempting to many young Basque men at the end of the seventeenth and beginning of the eighteenth century, and Chourio w as counted among this number. The number of Basque males who found success on the high seas during this time $\mathrm{w}$ as $\mathrm{w}$ holly $\mathrm{d}$ isproportionate to th eir $\mathrm{n}$ umbers. $\mathrm{C}$ ombining $\mathrm{c}$ ommercial, ma ritime, mercantile and military activities, Basque sailors were reaching the uttermost parts of the Earth. One reason for this attraction may be that Spain's ship construction industry was centered in the Basque country, where a plentiful supply of hardwood was located in the mountains. Most of the iron us ed in Spanish ship building was forged in this area as w ell. Thus, the Basque Navarre entered $\mathrm{m}$ aritime co mmercial activities i $\mathrm{n} \mathrm{ab}$ ig way. $\mathrm{M}$ any Basque $\mathrm{m}$ en $\mathrm{t}$ hus $\mathrm{d}$ eveloped outstanding $\mathrm{c}$ ommercial $\mathrm{h}$ abits a nd title s o f $\mathrm{n}$ obility a s w ell, to ma tch th eir accumulating fortunes. Caro Baroja notes that the spirit of Basque solidarity worked to bring many great and profitable economic enterprises to the fore in both seventeenth century Spain and America. ${ }^{38}$ Interestingly, Caro Baroja commented on those of Navarre in the Americas:

Everything seems to end. Another w orld be gins. There are new homelands, new patriotisms.... The i mportance of $\mathrm{t}$ he $\mathrm{d}$ escendants of $\mathrm{N}$ avarre in th is $\mathrm{d}$ ramatic moment is recognized. It is sufficient to $r$ emember the young ma $n$ Mina, and Iturbide, with their radical actions. It is enough to also remember the most useful Count of Guaqui. All of them are beyond the modest area of our investigation, but whether Creole or not, as the men of earlier times and later, the men of this time [the eighteenth c entury] served $w$ ell, maximizing th eir individual potential, and adjusting for events and people. ${ }^{39}$

Ricardo C ierbide M artinena of La U niversidad d el P aís V asco has gone e ven further, detailing a list of prominent Basques residing in Venezuela throughout the eighteenth century. ${ }^{40}$ According t o $\mathrm{C}$ ierbide Martinena, the Basque presence in Venezuela during the e ighteenth century can be distributed among four groups: 1) Those families who migrated there prior to the

\footnotetext{
${ }^{38}$ Caro Baroja, Hora Navarra, 33.

${ }^{39}$ Ibid., 392.

${ }^{40}$ Ricardo Cierbide Martinena, "La Compañía Guipuzcoana de Caracas y los vascos en Venezuela durante el siglo XVIII," Revista Internacional de Estudios Vascos 42, 1 (1997), 71-75.
} 
eighteenth century and owners of large estates; 2) Officials of the Spanish Crown; 3) Members of the G uipuzcoana $\mathrm{C}$ ompany ( mentioned in $\mathrm{C}$ hapter $\mathrm{O}$ ne); a nd 4) Those w ho a rrived from Basque lands as officials of this same company. These are just some of those at the top of an alphabetical list who arrived in Venezuela prior to the founding of the Guipuzcoana Company, and were, or whose descendants were, fundamental in establishing it in 1828:

Joseph $\mathrm{F}$ uctuoso A lzuru. $\mathrm{H}$ e dona ted $\mathrm{f}$ unds a nd $\mathrm{l}$ and $\mathrm{f}$ or $\mathrm{t}$ he $\mathrm{c}$ onstruction a nd maintenance of $\mathrm{R}$ oman $\mathrm{C}$ atholic $\mathrm{c}$ hapels a $\mathrm{t} \mathrm{C}$ havazquito, $\mathrm{S}$ anto $\mathrm{D}$ omingo, Pasohondo, Saguá and Cruces.

Manuel de Alzuru. He was the owner of vast herds of cattle in the Sabana Grande de Yguez.

Miguel de Aristeguieta. He built a private Roman Catholic chapel on his estate.

Gil de Arratia. H e was a large landlord, originally from Vizacaya in the Basque country.

Domingo de Arrieta. H e inspected the pue blos of the Laguna de $\mathrm{M}$ aracaibo in 1738 by order of the bi shop J oseph Félix V alverde. In the S ur d el Lago today, Arrieta is almost as common a name as Chourio, and there has been, and continues to $b$ e, a lo $t o f$ in termarriage $b$ etween th ese two $f$ amilies. A side $f$ rom the cooperation of Arrieta and Chourio in establishing the Guipuzcoana Company, it is probable that $t$ heir $r$ espective families $s$ hared many o ther $b$ usiness an $\mathrm{d} p$ ersonal transactions.

Ascain, or sometimes referred to as the Ascanio Family. M embers of this family held majority shares in the Guipuzcoana Company.

Simón Bolívar. He first went to Santo Domingo, where he worked as a royal court scribe be fore moving on to Venezuela. $\mathrm{He}$ was the first of the Bolivar family to reside in the New World.

Vicente Bolívar. He was a rich landowner who took up residence in Caracas, and father of the Great Liberator Simón Bolívar (1783-1830). This Bolívar was a legal auditor for the Royal Court and member of the Assembly, an organ created by the Guipuzcoana Company in 1751 to advance its interests in Caracas. He was also a patron of the Chapel of the Most Holy Trinity in Caracas.

Juan Chourió ${ }^{41}$ de Iturbide. He established the village of Perijá in order to serve as a ba se of ope rations i n pa cifying $t$ wo ba nds of $t$ he $\mathrm{M}$ otilones indios (Native

\footnotetext{
${ }^{41}$ In some Basque publications, Chourio's name appears with an accent over the (i).
} 
Americans), the Coyama and the Macoa, that w ere attacking cacao plantations in the regions roundabouts.

The i nclusion of $\mathrm{C}$ hourio in the $\mathrm{l}$ ist of Cierbide $\mathrm{M}$ artinena is $\mathrm{v}$ ery s ignificant in the context of $\mathrm{V}$ enezuelan historiography. $\mathrm{U}$ ntil recent time s, little, if a ny, attention w as $\mathrm{p}$ aid toward the role of either the black conquistadores or black colonial soldiers on fronts in Africa, the Americas, or the Caribbean. ${ }^{42}$ That Chourio employed free blacks on his Caribbean sloops and a lso u tilized a $\mathrm{A}$ frican milita ry contingent in putting d own $\mathrm{N}$ ative A merican rebellions, constitutes a new and overlooked category in regard to the African Diaspora in Venezuela.

\section{European Background}

To be tter unde rstand the c onditions that a llowed $\mathrm{J}$ ean $\mathrm{C}$ hourio to prosper a s a T ransAtlantic trader, it is necessary to look at some key events that transpired on the Iberian Peninsula in Spain and Portugal, as well as to the north of the Pyrenees in neighboring France from the late sixteenth through early eighteenth century. A s for the Spanish kingdom, it was under constant threat from w ithin and w ithout. I n May 1640 pe asants in $\mathrm{C}$ atalan rose up a gainst $\mathrm{C}$ astilian troops, with the rebels capturing Barcelona and killing the viceroy. The Catalans even went so far as to first d eclare themselves an independent republic, an d later as subjects of the French king, when doing so would garner military assistance from him. Thus, the unity of the Spanish kingdom had been destroyed, and it took twelve years for King Philip IV to sufficiently subdue the rebelling Catalans and regain a semblance of control. In order to assure the continued loyalty of the Catalan nobility, however, the S panish king was required to reaffirm all of their special

\footnotetext{
${ }^{42}$ Even $\mathrm{t}$ he 1 iberal eco nomist an d historian, Antonio Arellano $\mathrm{M}$ oreno, with $\mathrm{r}$ espect $\mathrm{t} \mathrm{o} t$ he African legacy in Venezuela, stated that, "the three essential functions delegated to blacks in colonial society were: 1) Working in the mines; 2) Working in the a gricultural sector with sugar cane, and especially cacao; a nd 3) Working as "beasts of burden,' i .e. p orters." Antonio Arellano M oreno, Orígenes de la economía venezolana (Caracas: U niversidad Central de Venezuela, 1982), 120.
} 
privileges, know $\mathrm{n}$ as fueros. ${ }^{43}$ This is v ery i mportant, be cause in a future $t$ ime the $\mathrm{S}$ panish Crown w ould ha ve to grant s uch favors to its Basque nobi lity a s w ell, s o a s to s ecure their continued cooperation.

There was a lso trouble brewing on S pain's w estern flank. In 1580, the S panish king, Philip II, inherited neighboring Portugal. The king promised that he would allow his Portuguese subjects to m aintain their ow $\mathrm{n}$ c ourts and 1 iberties. $\mathrm{H}$ e was $\mathrm{s}$ ure that this $\mathrm{w}$ ould $\mathrm{g}$ arner their loyalty, much as it had done with his subjects in Aragon. And as long as Philip II was alive, he kept his word and the Portuguese were content with Spanish rule. However, his successors had other $\mathrm{pl}$ ans. T hey a ppointed Castilians to the courts and royal of fices and i mposed he avy tax burdens on the Portuguese to finance Spanish military adventures on the continent and overseas. By 1640, the Portuguese had enough and launched a rebellion against the Spanish crown. The Portuguese nobles declared one from their own ranks as the new king. For the next twenty-eight years, the Spanish tried to regain control of Portugal, but to no avail. Portugal's traditional allies of England and France supplied the needed margin of military assistance to repel the occupying Spanish army. ${ }^{44}$

Despite this turmoil on the Iberian Peninsula, an excitement was stirring in the rest of Europe r egarding $\mathrm{s}$ tories that ha $\mathrm{d} \mathrm{l}$ ong $\mathrm{c}$ irculated $\mathrm{c}$ oncerning the unpr ecedented $\mathrm{w}$ ealth to be found on $\mathrm{t}$ he distant shores of S panish A merica. $\mathrm{N}$ aturally, this a ttracted the a ttention of the French. Even as early as the sixteenth century, French ships were covertly loading their wares onto Spanish caravels, freighted in Seville and bound for the Indies. By the seventeenth century, Robertson e stimated th at illic it $\mathrm{F}$ rench tr ade $\mathrm{w}$ ith th e S panish A merican $\mathrm{c}$ olonies s lightly

\footnotetext{
${ }^{43}$ Herr, Modern Spain, 43, 44.

${ }^{44}$ Ibid., 44.
} 
exceeded ten million francs annually. ${ }^{45}$ In fact, a scribe of the French Crown stated in 1691 that at least one-quarter of all the commerce carried out through the port of Cadiz with the Indies was French. ${ }^{46}$ And when hostilities broke out between France and Spain, those buccaneers who had swarmed the Antilles w ere en couraged by the French to carry out raids on S panish A merican colonial s ettlements. In $1699, \mathrm{G}$ overnor du $\mathrm{C}$ asse of $\mathrm{S}$ aint-Domingue led a $\mathrm{n}$ e xpedition of filibusters in the s acking of $\mathrm{C}$ artagena. $\mathrm{T}$ his e xpedition $\mathrm{w}$ as a ugmented $\mathrm{b}$ y a de tachment of French soldiers under the command of $\mathrm{B}$ aron du $\mathrm{P}$ ointis, and both a ttacking parties ended up quarrelling over the division of the booty. ${ }^{47}$

However, F rance w as a bout to be come m ore i ntimately $t$ ied to the fortunes of $\mathrm{S}$ pain, whose ki ng, P hilip IV, had onl y one s urviving s on, C harles II (1665-1700). This s on was mentally handicapped and unable to assume the regal duties. In addition, he was not capable of begetting any children. This ne cessitated a change in the ruling dynasty. Therefore, upon his death P hilip IV be queathed his kingdom to the grandson of Louis XIV, the French king. T he grandson of Louis XIV was the Duke of Anjou, and his claim to the Spanish throne was largely based upon $t$ he $m$ arriage of hi s grandfather to the da ughter of $\mathrm{P}$ hilip IV. T his is i mportant, because the Duke of Anjou ascended to the Spanish throne, assuming the title of Philip V, being the first Spanish king from the F rench line of the House of B ourbon that ruled in S pain unt il $1931^{48}$

The $\mathrm{H}$ apsburgs of A ustria $\mathrm{c}$ laimed $\mathrm{t}$ hat $\mathrm{t}$ he $\mathrm{t}$ hrone of $\mathrm{S}$ pain be longed $\mathrm{t}$ o A rchduke Charles, the grandson of Philip III. G reat Britain and the Netherlands immediately recognized Archduke $\mathrm{C}$ harles a s the $\mathrm{r}$ ightful $\mathrm{h}$ eir. $\mathrm{T}$ hey $\mathrm{r}$ easoned $\mathrm{t}$ hat a French and $\mathrm{S}$ panish a lliance,

\footnotetext{
${ }^{45}$ William Spence Robertson, France and Latin-American Independence (Baltimore: Johns Hopkins Press, 1939), 3.

${ }^{46}$ Ibid.

${ }^{47}$ Ibid., 3, 4.

${ }^{48}$ Herr, Modern Spain, 44.
} 
brought on by the ascendency of the Duke of Anjou, could either be broken in the royal courts or on the battlefield. But in either case, it had to be challenged as a French-Spanish alliance would surely create a near invincible maritime and colonial power. Because the Duke of Anjou (Philip V) would not abdicate his throne, the Spanish War of Succession ensued, becoming both a major European and colonial conflict that would not be settled until the signing of the Treaty of Utrecht in 1713. B asically, this treaty represented a compromise. It allowed Philip V to maintain the crowns of Castile and Aragon, as well as most of Spain's New World colonial empire, but ceded control of $i$ ts Italian and Low $\mathrm{C}$ ountries' pos sessions to A ustria and the $\mathrm{i}$ sland fortress of Gibraltar to $G$ reat Britain. It also c eded certain mo nopoly trade privileges to the British for Spanish colonies in the New World. This caused some grief for Chourio and others associated with the French; and so it was that Chourio and others involved in the Trans-Atlantic trade would find themselves tossed to and fro $\mathrm{b} y \mathrm{t}$ the conditions of e conomic and political in stability th at resulted from the issues of royal succession in Europe.

The he avy military losses suffered by S pain during the W ar of S uccession, both at sea and on the continent, and especially the loss of Gibraltar, right at their own backdoor (Southern flank), onl y s erved $\mathrm{t} \mathrm{o}$ reinforce $\mathrm{t}$ he $\mathrm{i}$ dea $\mathrm{t}$ hat $\mathrm{G}$ reat Britain $\mathrm{w}$ as $\mathrm{S}$ pain's $\mathrm{m}$ ortal e nemy. ${ }^{49}$ Therefore, $t$ he S panish w ere now 1 egally forced t o do bus iness $w$ ith the B ritish in the $\mathrm{N}$ ew World, rather than the French, This, however, did not mean that they liked it.

At the beginning of the War of Succession, moreover, not every party in S pain was on board with Philip V, and there would be repercussions for this. The nobles in Aragon, Catalonia and Valencia recognized Archduke Charles as their rightful king, having more confidence that a Hapsburg, rather than a Frenchman, would continue recognizing their privileges. But even with help from G reat B ritain and A ustria, these r ebel ki ngdoms proved no match for the might of

${ }^{49}$ Ibid., 44, 45 . 
Philip V's Castilian forces. As a measure of retaliation toward these rebelling kingdoms, Philip V revoked their privileges and abolished their autonomous courts. Henceforth, these kingdoms were required to send their representatives to the royal co urt in $\mathrm{C}$ astile to resolve an $\mathrm{y} i$ ssues, even of a local nature. In addition, Philip V appointed Castilian military officers, called captains general, to replace the regional viceroys. These captains general were answerable only to Philip V. The king also sent corregidores, or royal managers, to run the cities in these rebellious areas, and a dditional $t$ axes $w$ ere a lso 1 evied upon the popul ace $t$ here. Only $t$ he provinces of $t$ he Basques and Navarre preserved their traditional fueros. ${ }^{50}$ This is significant because Chourio, being of Basque a nd French de scent, $\mathrm{w}$ as allowed s ome $\mathrm{c}$ ommercial privileges not us ually afforded to traders from other provinces.

\section{The French}

Almost i mmediately up on P hilip V 's a scension t o t he S panish $t$ hrone, he be gan $t$ o establish e conomic pol icies favorable to F rance. One result of this was that Jean de Chourio found his edge in the New World doing business with the French Royal Company of Guinea. It was one such business enterprise formed as a result of the rise of the house of Bourbon to the throne of Spain, by writ of 27 August 1701, for the introduction into Spanish America of 48,000 blacks from the French domains in Africa.

According to Robertson: "By a treaty between France and Spain in the autumn of 1701, the F rench Company of Guinea was a uthorized to carry on the slave trade with the Indies, to build ships in Spanish ports on the Pacific Ocean, and to dispose of the merchandise which it

\footnotetext{
${ }^{50}$ Ibid., 45.
} 
received in $r$ eturn for Negro s laves. U nder cover of this c ontract, a n e xtensive i llicit t rade developed between French merchants and Spanish colonists." 51

Clearly, P hilip V co nsciously acted t o i nclude F rance i $\mathrm{n} t$ he $\mathrm{p}$ rofitable em erging American markets. A nd according to Hussey, the War of Succession that followed the rise of Philip V was nothing m ore than a c onflict for c ontrol of A merica's riches; and F rance w ould win, for its efforts, a guaranteed monopoly over the African slave trade and a tacit license for the ongoing w ork of $\mathrm{i}$ ts s lave traders. ${ }^{52}$ This di d not c ome w ithout c onditions, how ever, for in Maracaibo, Santa Marta, Cumaná and Barlovento, the company could not sell the slaves for any more than 300 pesos each. This restriction was not limited to just the ports of the province of Venezuela. The co mpany w as committed to pay the $\mathrm{S}$ panish $\mathrm{C}$ rown a $\mathrm{n}$ a dvance of 264,000 pesos. It was then licensed to remove or introduce, free of any duties, food and supplies required for the maintenance of blacks during the sailing, or in the factories that the company established in the ports of the Indies. ${ }^{53}$

These foods and supplies could not be traded on the open market, under the pretext of preventing the G uinea C ompany franchise from de veloping a c landestine commerce $\mathrm{w}$ ith $\mathrm{the}$ French. Therefore, a penalty of death was imposed on any Spanish subject buying French goods at a value of more than 100 pesos. Despite the penalty, this illegal trade actually flourished, and the French came to traffic freely ev erywhere, with the authorities unable to prevent it. In fact, sometimes the authorities just looked the other way, because during the long years of the War of Spanish S uccession (1700-1713) s ome c olonies, i ncluding V enezuela, w ere exposed t o g reat

\footnotetext{
${ }^{51}$ Robertson, France and Latin-American Independence, 4.

52 Roland Dennis Hussey, Caracas Company, 1728-1784 (Cambridge: Harvard University Press, 1934), 38-40.

${ }^{53}$ Arcila Farías, Reformas económicas del siglo XVIII, 2: 52, 53.
} 
hardships, and the supply of essentials was one of the biggest problems they had to overcome if their settlements were even to survive, let alone prosper. ${ }^{54}$

On more than one oc casion F rench ships helped alleviate acute food shortages suffered by Spanish American colonies with meager resources. In reality, throughout the entire period of conflict in which Spain and France participated as allies against England, the Guinea Company enjoyed a prosperous trading contract in Spanish America, but within the narrow limits imposed by the ongoing a rmed s truggle. The $\mathrm{G}$ uinea $\mathrm{C}$ ompany a lso e ncountered tenacious oppos ition from $\mathrm{t}$ he $\mathrm{m}$ erchants of Cadiz a nd $\mathrm{S}$ eville, $\mathrm{w}$ ho $\mathrm{w}$ ere not hi ding $\mathrm{t}$ heir fears o $\mathrm{t} t$ he risks of competition in the American markets posed by the activity of the French enterprise. ${ }^{55}$

Caracas merchants were also affected in their reciprocal trade with both Spain and New Spain (now Mexico). Many of the Spanish officials in the ports of the Indies were in opposition to the Guinea Company, at times being overzealous in trying to prevent trade beyond the terms of the contract, even when the inhabitants of their territories wanted or needed such trade. On other occasions, the Spanish officials in American ports cited some of the same political reasons that ag itated their $\mathrm{p}$ assions ag ainst $\mathrm{F}$ rance $w$ hen they $w$ ere $\mathrm{b}$ ack in $\mathrm{S}$ pain. G iven this hostile attitude towards the French and the Guinea Company assumed by some of the Spanish officials and the regional governors, especially in Cartagena of the Indies, the company filed a petition to the king of Spain for redress. Then, in a royal decree of 23 December 1704, Philip V ordered the proper treatment of the French and the faithful fulfillment of the contract. ${ }^{56}$

The Crown attempted several times to reduce the company's business to the terms agreed upon, and gave orders not to handle the sale of food and supplies that were introduced under the pretext of be ing for consumption by blacks. B ut nothing could stop the French in their trade.

\footnotetext{
${ }^{54}$ Ibid., 53.

${ }^{55}$ Ibid., 54 .

${ }^{56}$ Ibid.
} 
Sometimes it was tolerated by the authorities because they felt as if they were forced by the scarcity imposed by the war to allow the colonists access, at least on a temporary basis, to French goods. And often the trade just went on in open violation of the contract and the strict provisions of the $\mathrm{S}$ panish $\mathrm{m}$ onarch. In a ny case, the $\mathrm{F}$ rench continued to s upply the A merican $\mathrm{m}$ arkets through the auspices of the Royal Company of Guinea; and in its first year, 1701, the company introduced to Venezuela the largest number of blacks so far in a single operation. This endeavor comprised the landing of a fleet of eight ships transporting a total of 778 slaves, of whom 18 died from va rious i llnesses a cquired during the $30 \mathrm{~d}$ ays that the boa ts remained in the por $\mathrm{t}$ of $\mathrm{La}$ Guaira. A ccording to Arcila F erías, this death $\mathrm{r}$ ate $\mathrm{w}$ as then considered $\mathrm{r}$ ather low. A rcila Ferías considers it $r$ emarkable that the en tire co mplement of $b$ lacks $h$ ad ar rived in La $\mathrm{G}$ uira intact, despite a very long sailing across the Atlantic with the slaves crammed in to the narrow compartments. $^{57}$

However, i $\mathrm{t}$ he years following, this $\mathrm{flow}$ of $\mathrm{A}$ frican s laves $\mathrm{c}$ ame to a co mplete standstill, a c onsequence of the ong oing $\mathrm{w}$ ar $\mathrm{t}$ hat $\mathrm{e} x$ tended $\mathrm{t} o \mathrm{t}$ he $\mathrm{C}$ aribbean a nd circumCaribbean regions. The English, buoyed by their allies, affirmed their dominance of the sea in the Caribbean and waters off the African coast. Thus, the increased pressure on French shipping forced the G uinea C ompany to us e P ortugal's maritime r esources for the ex traction of black slaves from Portuguese areas of influence in Africa. The trading companies wanted an exemption from import and export taxes in the American colonies, especially the lucrative export of cacao from Caracas to ports in Spain and America, alleging that this was so authorized by the contract

\footnotetext{
${ }^{57}$ Eduardo Arcila Farías, Economia colonial de Venezuela (México, D.F.: Fondo de Cultura Económica, 1946), 162, 163.
} 
of 1 701. $\mathrm{N}$ evertheless, $\mathrm{P}$ hilip $\mathrm{V}$ or dered that $\mathrm{t}$ axes a nd fees ne eded t $\mathrm{o}$ be $\mathrm{c}$ ollected on a ny company transactions carried out in Spanish domains. ${ }^{58}$

After a few years, however, it appears as though the authorities in La Guaira wanted to avoid pot ential trouble with the C rown. Therefore, these a uthorities 1 imited the dur ation that French boats could remain docked at their port. Because La Guaira served as the main terminus for the i mport of A frican s laves i nto V enezuela a nd the principal por $t$ for the export of the profitable $\mathrm{C}$ aracas $\mathrm{c}$ acao, $\mathrm{it} \mathrm{w}$ as i mperative $\mathrm{f}$ or $\mathrm{t}$ he French $\mathrm{t} \mathrm{o}$ s eek another por $\mathrm{t} \mathrm{o}$ ffering a friendlier business environment, or at le ast a port o ffering a s imilar c ontract to the o ne they enjoyed at La Guaira. Hence, we note a gradual shifting of the Guinea Company's business to a base of operations at Willemstad on the island of Curaçao. By 1708 even Chourio completed the move of his office and operations from La Guaira to Willemstad. ${ }^{59}$ The Guinea Company ceased operations a s a c orporate e ntity in 1713, when the R oyal British S outh S eas C ompany was granted a monopoly over the trade of African slaves in Spanish America in accordance with the provisions of the Treaty of Utrecht. ${ }^{60}$

The Treaty of Utrecht stipulated that ports in the Spanish colonies w ould henceforth be closed to all foreign merchants and transferred to the British the lucrative contract to engage in slave traffic that had previously been enjoyed by the French.

The Tory ministers of Queen Anne, who up until the negotiations began at Utrecht were the principal spokesmen in the anti-French alliance, pressed for a British "blue water" policy, i.e. they w ere s eeking vi ctories and s poils overseas. And during the finalizations at U trecht, this same group pus hed aside their former Dutch allies for the purpose of making themselves, and

\footnotetext{
58 Ibid.

${ }^{59}$ Rupert, online resource, Roots of Our Future.

${ }^{60}$ Arcila Farías, Reformas, 54-55.
} 
hence the British, the sole "brokers and chief beneficiaries of the peace."61 They would hence be willing $\mathrm{t} \mathrm{o}$ a llow $\mathrm{P}$ hilip of A njou $\mathrm{t} \mathrm{o}$ ke ep hi s S panish $\mathrm{c}$ rown, but pr essed $\mathrm{t}$ he $\mathrm{F}$ rench $\mathrm{w}$ ith audacious c ommercial and colonial claims. ${ }^{62}$ King Louis XIV of France felt that he could be generous at making concessions in the Spanish Empire, and instructed his chief trade negotiator, Nicolas Ménager, to go to London and do $\mathrm{j}$ ust that. Thus it was that the French allowed their exclusive trading contract in S panish c olonial A merica (asiento) to pass into B ritish hands. ${ }^{63}$ From this point we see Chourio and other French traders cut off from any direct support from the Spanish C rown. T hey would ha ve to find their ow $\mathrm{n} w$ ay, or a $\mathrm{t} l$ east an excuse $t \mathrm{o} g$ et their proverbial "foot back in the door," so to speak.

In $\mathrm{C}$ adiz, how ever, it $\mathrm{s}$ hould be not ed that there w ere e stablished French $\mathrm{m}$ ercantile houses through which illicit traffic with the Spanish American colonies continued to take place. ${ }^{64}$ French government documents from this time indicate that French commerce "took the route by way of Cadiz for the disposal of such of her agricultural and manufacturing products as found markets in S panish A merica." ${ }^{65}$ This i llegal trade w ould not 1 ast 1 ong, nor be sufficient for Chourio to regain the good graces of the king. He would have to find a new angle.

The British took control of the slave trade following the Treaty of Utrecht; and moreover, the $\mathrm{F}$ rench G uinea Company w as di sbanded and most of these $\mathrm{B}$ asque and ot her non-English traders reverted to either importing African slaves illegally or bringing them into Venezuela on "special orders" from King Philip V. U ntil the Guipuzcoana Company was e stablished, all of

\footnotetext{
${ }^{61}$ Daniel A. Baugh, “Great Britain's ‘Blue Water' Policy, 1689-1815,” International History Review 10 (1988), 35 58.

${ }^{62}$ Miquelon, "Envisioning the French Empire," 653, 654.

${ }^{63}$ Ibid., 655, 656.

${ }^{64}$ Robertson, France and Latin-American Independence, 5.

${ }^{65}$ This was Robertson's paraphrase of the gist of this document: "Rapport su la législation politique que régit le Commerce de la France, a l'egard le l'Amérique Espagnole et de Colonies Étrangères en général," 2 F ebruary 1716, A.rchives du Ministère des Affaires Étrangères, Mémoires et Documents, Amérique, Paris, 31.
} 
these non-English traders had to go back to the pre-asiento system of obtaining individual royal licenses if they wanted to be part of the lucrative slave trade.

Consider the following data:

Table 2.1: Legal Importation of African Slaves in the Spanish American Colonies ${ }^{66}$

\begin{tabular}{|c|c|c|}
\hline Years & Slaves Imported & References, Observations \\
\hline 1700 & 10,000 & Pending Asiento: Royal Guinea Company \\
\hline $1701-1711$ & 48,000 & Asiento: Royal Guinea Company \\
\hline $1712-1713$ & 12,000 & Individual Licenses \\
\hline $1713-1743$ & 144,000 & Asiento: Royal South Seas British Company \\
\hline $1728-1778$ & 20,000 & $\begin{array}{l}\text { Guipuzcoana Company a nd Individual } \\
\text { Licenses }\end{array}$ \\
\hline
\end{tabular}

Note: Illegal importation of slaves in eighteenth century: 390,000 (approximately).

To he lp unde rstand this, A frican s laves c ould legally be brought into V enezuela under three distinct s ystems: $F$ irst there $w$ as a $\mathrm{s}$ ystem of $\mathrm{i}$ ndividual 1 icenses for $\mathrm{g}$ eneral or $\mathrm{s}$ pecial concessions to be c arried out in a s tipulated pe riod of time. S econd, there w as a s ystem of asientos (royal charters) and companies. T hird and last, there w ere royal m onopolies g ranted over all general trafficking. ${ }^{67}$ The first category was sometimes applied to the introduction of black soldiers into the country for the purpose of subduing indigenous peoples in varied states of non-compliance or outright rebellion to Spanish authority. Hence it would conform nicely to the case of Juan de Chourio.

\section{The British}

The British assumption of those s lave trading privileges pr eviously held by the French forever a ltered the ba lance of e conomic pow er in Europe, a nd he nce the w orld. $\mathrm{T}$ he profits

\footnotetext{
${ }^{66}$ Brito Figueroa, Estructura Económica, 110.

${ }^{67}$ Miguel A costa S aignes, Vida de los esclavos negros en Venezuela (Valencia, V enezuela: Vadell H ermanos Editores, 1984), 25.
} 
garnered by Great Britain from slave trafficking would fuel its economic and military expansion, propelling it $\mathrm{f}$ orward to $\mathrm{b}$ ecome the $\mathrm{f}$ irst global imp erialist $\mathrm{p}$ ower. $\mathrm{T}$ he s lave trade, le gal or illegal, and carried out under the flags of sundry European pow ers, or at least on their behalf, increased the $\mathrm{m}$ ass of accu mulated ca pital $\mathrm{t} o$ be $\mathrm{i}$ nvested $\mathrm{b}$ y $\mathrm{t}$ he bo urgeoisie $\mathrm{t}$ o a ugment economic development in their respective nations. The Royal South Seas British Company, that replaced both the $\mathrm{P}$ ortuguese a nd French $\mathrm{m}$ onopolies of $\mathrm{the} s$ lave $\mathrm{t}$ rade, was o rganized as a powerful $\mathrm{j}$ oint $\mathrm{s}$ tock $\mathrm{c}$ ompany. $\mathrm{B}$ eing integrated $\mathrm{w}$ ith th $\mathrm{e} \mathrm{c}$ apital $\mathrm{p}$ rovided $\mathrm{b} y$ th $\mathrm{e} B$ ritish aristocracy, the bourgeoisie and the commercial lenders of the most important cities of Europe, the company spilled over national boundaries. It brought seemingly divergent elements together for the purpose of exploiting one of the most economically productive capitalist ventures of all time, the traffic in African slaves. Queen Anne of England, Philip V of Spain and the Duke of York, who served as Chairman, numbered among the most pow erful on the board of the Royal South S eas Company. T he old rivalries were set a side in the name of profit. W ith increased investment of the capital generated through slave trafficking came increased manufactures, the wider availability of goods and services in England and to a lesser extent, the other countries of Europe. ${ }^{68}$ And a long with the s eeming de light of the European masses with this new w ealth, also $\mathrm{c}$ ame a 1 oss of their 1 ast ve stiges of de cency and $\mathrm{c}$ onscience. W ho $\mathrm{m}$ ourned $\mathrm{f}$ or $\mathrm{t}$ he Africans, whose blood mixed with the mortar of the new manufacturing industries?

Not without reason Karl Marx penned the following concerning this tumultuous time in England:

Various countries cynically boasted of all the outrages that could serve as a means of capital accumulation. Just read, for example, the naive and unblemished Annals of Commerce, compiled by A. Anderson. They proclaimed to the four winds the triumph of the political wisdom of England, which, in the Peace of Utrecht, this country garnered $\mathrm{f}$ rom the $\mathrm{S}$ panish, $\mathrm{b}$ y $\mathrm{t}$ he $t$ reaty $\mathrm{p}$ rovisions, $\mathrm{t}$ he pr ivilege of

\footnotetext{
${ }^{68}$ Brito Figueroa, La Estructura Económica, 111-112.
} 
operating between Africa and the West Indies. England won the privilege of being the s ole supplier of s laves to Spanish America until 1743, with four thousand eight hundred blacks to be imported there e ach year. This trade was carried out while under an official flag to also cover for the British smuggling of other goods. Liverpool is so great thanks to the trade in blacks. This trade was their method of accumulation. A nd it still is to day, s o m uch s o t hat di stinguished Liverpool residents sing their praise of the slave trade, being literally carried aw ay in their passion $t$ hat cel ebrates $t$ he $s$ pirit of commercial e nterprise, $w$ hich produces famous navigators and throws huge profits continually in their direction. In 1730, Liverpool was found with 15 ships engaged in the slave trade; in 1753 there were 53 ; in 1760,74 ; in 1770,90 ; and in $1792,132 .^{69}$

Profit w as the motivating force be hind B ritish ove rseas expansion; a nd labor, whether obtained from free subjects of the monarch or enslaved Africans, was just another commodity to be bou ght a nd s old. The asiento granted t o the British $\mathrm{C}$ ompany on $26 \mathrm{M}$ arch 1713, in accordance with the Treaty of Utrecht, was an outright monopoly of all general slave traffic. It specifically allowed for the British to exercise a monopoly over the trade for thirty years, starting on 11 May of that year and lasted until 11 May 1743. The company promised to import 144,000 African s laves i nto $\mathrm{V}$ enezuela dur ing this pe riod at a $\mathrm{r}$ ate of 4,800 pe $\mathrm{r}$ year. $\mathrm{O} \mathrm{ft}$ he 4,800 brought in annually, an import tax was paid of 33 pe sos and eight escudos only on the head of each of the first 800 . T he company anticipated a near profit of 200,000 pe sos, with 100,000 to be received within the first two months of the contract and the remaining 100,000 to be received within the following two month period. T he provisions of the charter called for the A fricans imported to Barlovento, Cumaná and Maracaibo to be sold between 150 and 300 pesos each, and the company was also to be afforded special privileges to import diverse merchandise. ${ }^{70}$

Clearly, Chourio and other freelancers were going to be squeezed; but since cacao was the $\mathrm{m}$ ost $\mathrm{p}$ rofitable $\mathrm{V}$ enezuelan ex port, it $\mathrm{w}$ as necessary for the $\mathrm{C}$ rown $\mathrm{t} \mathrm{o} \mathrm{p}$ rotect $\mathrm{t}$ he cacao plantations in the lands surrounding Lake Maracaibo. For this purpose Chourio was permitted to

\footnotetext{
${ }^{69}$ Karl Marx, El Capital, T. 1, 2 vols.. (México: Fondo de Cultura Económica, 1946) 2:849-850. Original published in German as Das Kapital in1867.

${ }^{70}$ Brito Figueroa, La Estructura Económica, 108.
} 
bring in 600 Africans in 1722, warriors and their families from the Imbangala of Angola, ${ }^{71}$ who shared a long history of working as mercenaries for the Portuguese and other Europeans. And this d espite the exclusive c ontract th at the R oyal S outh S eas B ritish C ompany $\mathrm{h}$ ad $\mathrm{w}$ ith the Spanish C rown, be cause $\mathrm{C}$ hourio's bl acks w ere not $\mathrm{c}$ ommon 1 aborers $\mathrm{f}$ or $\mathrm{t}$ he $\mathrm{m}$ ines or plantations, but highly trained soldiers and their dependents who would carry out the specialized task of pacifying a rebellious indigenous tribe in the regions around Lake Maracaibo.

The B ritish acted in 1722, how ever, when factores [agents] of their R oyal S outh S eas Company presented claims against the license granted to Juan de Chourio on 9 May of that same year by King P hilip V. The pu rpose of Chourio's license w as to i mport bl acks and others in order to establish a village at Perijá and subdue a rebellious indigenous population in the name of the $\mathrm{S}$ panish $\mathrm{C}$ rown. $\mathrm{T}$ he $\mathrm{B}$ ritish a gents a sserted $\mathrm{t}$ hat de spite $\mathrm{t}$ he $\mathrm{s}$ upposed uni queness of Chourio's mission in the regions round about Lake Maracaibo, he should not have exercised any option to introduce Africans into that situation outside the prevue of their company. Therefore, on 21 July $1722,{ }^{72}$ another royal decree was issued stipulating that Chourio subject himself to the agents of the British Company to obtain any Africans he might require, and that he should, under no conditions, sell any of these at any price over 300 pe sos. $^{73}$ The Real Cédula [Royal Order] issued to Don Juan Chourrio on r epeal of permission to introduce 600 s laves to Maracaibo, 31 July 1722 is given in full below. ${ }^{74}$

As pe $\mathrm{r}$ the or der of $9 \mathrm{M}$ ay of this year, I ha ve licensed D on J uan Chourrio, a resident of $t$ he $c$ ity of Maracaibo, in t hat pr ovince, $t o$ e stablish a $t$ own a nd populate it and surrounding lands, and to pacify some of those jurisdictions, under different conditions, one of them be ing the granting of permission to introduce

\footnotetext{
${ }^{71}$ These and other Angolan connections will be explored more fully in the following chapter.

${ }^{72}$ Acosta Saignes' date of 21 July 1722 conflicts with the date appearing on the document in the archives, given as 31 July 1722.

${ }_{74}^{73}$ Acosta Saignes, Vida de los esclavos, 54.

${ }^{74}$ In contrast to other documents pertaining to Chourio, this document spells his name with a double $r$. Philip V to Juan d e Chourrio, 31 July 1722, Documentos del Archivo Histórico Nacional de Bogotá, Salón de la Colonia, Reales Cédulas, Tomo VII, fols. 739 r. -740 r.
} 
into these areas, for their own enhancement as well as for the sake of the mission, $600 \mathrm{bl}$ ack and ph ysically fit s laves, a nd that this i mportation be free of s ome duties and taxes in accordance with the provisions of Law 7, Title 3 of Book 4. However, it was brought to my attention by the Asiento (chartered contractor for the i mportation of bl acks), in c onsultation on $15 \mathrm{~J}$ une, that this i mportation is contrary and opposed to chapters 18 and $19 \mathrm{w}$ ith the adjusted provisions for the Royal Company of England and their exclusive rights to the introduction of black slaves in the Indies. Therefore, I resolved to conform precisely to those chapters of $t$ he $c$ ompany a ccords, a nd ha ve a djusted $t$ he $\mathrm{C}$ rown pol icy $\mathrm{t}$ o $\mathrm{r}$ escind $\mathrm{t}$ he condition of Don Juan Chourrio.

Therefore, I h ereby $r$ epeal an $\mathrm{d}$ can cel $\mathrm{t}$ he $\mathrm{p}$ ermit $\mathrm{i}$ ssued on $\mathrm{c}$ ondition $\mathrm{t}$ o $\mathrm{t}$ he referred Don Juan Chourrio, with the expressed 600 black slaves to be introduced, as the British Company has the sole authority to bring blacks to Barlovento, Santa Marta, $C$ umaná a nd M aracaibo; and $\mathrm{b}$ asing this on $\mathrm{C}$ hapter $8 \mathrm{o} \mathrm{fthe} \mathrm{c}$ hartered agreement, no one can sell in these ports any slave at a price exceeding 300 pesos. Thus, $\mathrm{m}$ ay $\mathrm{t}$ he $\mathrm{bl}$ acks of $\mathrm{D}$ on $\mathrm{J}$ uan $\mathrm{C}$ hourrio be $\mathrm{s}$ ubject $\mathrm{t}$ o $\mathrm{t}$ he $\mathrm{C}$ ompany of England according to the provisions of the law as set by the Viceroy, President and Oridores (Judges) of the R oyal Audencia (Court) of the N ew Kingdom of Granada, governor a nd $r$ oyal of ficials of $\mathrm{M}$ aracaibo and ot her $\mathrm{j}$ udges a nd ministers who, in part or in full compliance touching on this, my resolution, do keep, satisfy and perform accurately and timely all that I have ordered. As to the next question, how ever, concerning the royal order of the aforementioned $9 \mathrm{May}$ of this year, I void it and make it of no value or effect, and that is my will.

De Balsaín, the $31^{\text {st }}$ day of July, 1722. I, the King, by order of O ur King the LORD. Don Francisco de Arana (there are three seals). I annul the permission granted t o D on J uan Chourrio f or the introduction of $600 \mathrm{bl}$ ack s laves in the Province of Maracaibo.

In this matter, how ever, the colonists were behind Chourio, and in the next chapter the events that transpired in Períja will be more fully developed. So despite the limitations imposed on Chourio to sell any slaves at no m ore than 300 pe sos each, this venture meant much more than just another commercial transaction, and he was committed to fulfilling the dual mission of pacifying the rebelling indigenous population and establishing a town to the glory of God and his Catholic Spanish king. 


\section{French Attitudes toward Africans Impact Chourio}

Before proceeding further into the settlement of Perijá and its surrounding area and the controversy surrounding the British claims against Chourio, it would be good to examine some of the pos sible m otivations be hind C hourio's e ngagement w ith A frican pe oples. O ne cannot divorce Chourio from his French connections. While there are seven Basque Provinces situated in the western extension of the Pyrenees, it should be noted that three of them are on the French side of the $\mathrm{m}$ ountainous $\mathrm{c}$ hain. $\mathrm{T}$ he $\mathrm{t}$ hree $\mathrm{F}$ rench Basque pr ovinces a re $\mathrm{N}$ afarroa Beherea, Lapurdi and Zuberoa. The four S panish B asque provinces a re A raba, Biskaia, Gipuzkoa and Naffaroa. Although Basque territory has long been divided between the two nations of France and $\mathrm{S}$ pain, the Basques consider themselves to be one pe ople. T he B asque coat of a rms, for example, is emblazoned the words, "Zazpiak Bat," which means that the "Seven are One," thus emphasizing $\mathrm{t}$ heir s ense of uni ty. ${ }^{75}$ Nevertheless, $\mathrm{t}$ hroughout $\mathrm{t}$ he s eventeenth $\mathrm{c}$ entury, bot $\mathrm{h}$ France and Spain were consolidating into strong nation states under absolutist monarchs. Thus, the Basque people continued to suffer further integration into either France or Spain, depending on which side of the Pyrenees they found themselves. With the signing of a treaty that fixed the border between France and Spain in 1659, the process of Basque integration into the cultural and political orbits of either of these two countries only accelerated. Since the creation of the French and S panish frontier, it has therefore be en increasingly n ecessary in many spheres to think in

\footnotetext{
${ }^{75}$ Symbols of Basque Unity (fact sheet), undated, Basque Museum and Cultural Center, 611 Grove Street, Boise, ID 83702 , received on 13 July 2009. This pamphlet also explains the origin of the coat of arms for each of the Basque provinces. Interestingly, Nafarroa in Spain and Nafarroa Beherea in France share the same coat of arms. The gold chains on a field of red represent those that surrounded the tent of the Moorish Caliph when his forces were captured in 1212 by Sancho the Strong, King of Nafarroa, at the battle of Las Navas de Tolosa. O ther symbols represent confiscated $\mathrm{M}$ oorish $\mathrm{r}$ iches distributed $\mathrm{t} \mathrm{o}$ Christian $\mathrm{c}$ hurches t hroughout $\mathrm{t}$ he $\mathrm{K}$ ingdom of $\mathrm{N}$ afarroa. $\mathrm{N}$ afarroa Beherea was the northernmost portion of the ancient kingdom, and when the French and Spanish concluded the Treaty of the Pyrenees in 1659 , without first consulting the Basque people, this northernmost portion was ceded to France. $\mathrm{B}$ ecause $\mathrm{N}$ afarroa Beherea was subsumed $\mathrm{b}$ y $\mathrm{t}$ he $\mathrm{F}$ rench i nto their $\mathrm{p}$ re-existing ki ngdom, $\mathrm{t}$ he $\mathrm{B}$ asque leadership there did not deem it necessary for the new province to adopt an emblem apart from the original coat of arms of Nafarroa on the Spanish side of the frontier.
} 
terms of a distinction between French Basques and Spanish Basques. ${ }^{76}$ Juan de Chourio was of the first generation born under uncontested French rule. He was schooled in French and loyal to the French Crown.

With respect to Africans, however, France had a troubled past, especially when it came to the $\mathrm{s}$ ad hi story of $\mathrm{r}$ acism a nd s lavery. France $\mathrm{w}$ as a $\mathrm{m}$ ajor $\mathrm{pl}$ ayer, $1 \mathrm{ike}$ the British, $\mathrm{D}$ utch, Portuguese and Spanish, in the establishment of slave societies. For the French in the sixteenth and seventeenth centuries, this was particular to both the Greater and Lesser Antilles; hence the stage was already set for Chourio to move in and take advantage of it.

Certainly, the dynamics of racism varied in accordance with cultural contexts throughout the French empire. There w as a v ariation of black-white d ynamics within France, A frica, and the New W orld that impacted all of Chourio's decisions with respect to the imported A fricans. France was decidedly a major player in European overseas ex pansion, so the ex periences with and conceptions of black people by individuals like Chourio helped to form images of Africans in $\mathrm{W}$ estern cu lture. Wh ile $\mathrm{m}$ any of $\mathrm{t}$ he $\mathrm{F}$ rench ex periences $\mathrm{w}$ ere $\mathrm{s}$ imilar $\mathrm{t}$ o $\mathrm{t}$ hose o f o ther expanding European powers that clashed with foreign peoples during the course of enslavement and empire building, it should be noted that Frenchmen have long asserted that their countrymen, unlike their E uropean ne ighbors a nd their w hite c olonists in the $\mathrm{N}$ ew World, ha ve g enerally upheld the principles of racial equality both on the home front and overseas. Henri Blet, in his three vol ume t reatise o $\mathrm{n}$ t he hi story of France, publ ished in 1950, s tated e mphatically that,

\footnotetext{
${ }^{76}$ William A. D ouglass a nd J oseba Z uliaka, Basque Culture: Anthropological Perspectives (Reno: C enter fo r Basque Studies, University of Nevada, 2007), 104. The French and Spanish frontier was not officially demarcated with border stones until 1868. It has remained one of the oldest and stable border regions in Europe. Some Basque people on both sides of the border, however, have been struggling for more political autonomy.
} 
"Frenchmen have never adopted the racial doctrine affirming the superiority of whites over men of color."77

However, de spite the a ssertions of $\mathrm{B}$ let, t he i nitial F rench r eactions t o blacks, w hich began in the 1530s, were similar to those of the English, Portuguese and Spanish. F rance, like England, Portugal and Spain, thrived in the context of a Christian population within the borders of a centralized political state. The material cultures that flourished throughout Western Europe during this time were similar as well. Thus, when contrasted with the traditions of peoples in the non-European w orld, s uch as blacks or $\mathrm{N}$ ative Americans, it s hould c ome as no s urprise that Europeans would consider them "particularly unusual," at best. ${ }^{78}$

Frenchmen had traveled to $v$ arious parts of A frica, but it was mostly W est A frica that helped to shape the F rench reaction toward A frican peoples ove rall and to fix ideas about the African continent in the French imagination. This was also the area where the French enjoyed their 1 ongest a nd $\mathrm{m}$ ost $\mathrm{i}$ mportant $\mathrm{r}$ elations $\mathrm{w}$ ith $\mathrm{A}$ frican pe oples. $\mathrm{T}$ his e ncompassed a relationship that would span the centuries, until decolonization in Francophone Africa beginning in the late 1950 s and early 1960 s. $^{79}$

By the middle of the sixteenth century, moreover, French traders plied the coast of West Africa seeking to extend commerce in gold, gum, and ivory. This was also the start of the slave trade for France, but it didn't really take off for another one hund red years. Nevertheless, the groundwork was being laid for an extensive French presence on the A frican continent. B y the 1630s, a group of Rouen merchants had actually established a fort at the mouth of the Senegal River, near to the site where the town of Saint-Louis would later be constructed. This fort would

\footnotetext{
${ }^{77}$ Henri Blet, France d'outre mer: L'oeuvre coloniale de la troisième république, 3 Vols. (Paris : B. Arthaud, 1950) $, 3: 284$.

${ }_{78}$ William B. Cohen, French Encounter with Africans: White Response to Blacks, 1530-1880 (Bloomington: Indiana University Press, 1980), xv, xvi.

${ }^{79}$ Ibid., xvii.
} 
serve as the base for a more active French involvement throughout West Africa, whence French traders a nd a dministrators w ould go on $\mathrm{t}$ o e stablish a commercial a nd political ne twork bot $\mathrm{h}$ inland, as well as up and down the coast. ${ }^{80}$

The $\mathrm{F}$ rench pr esence in the $\mathrm{C}$ aribbean, how ever, be gan in $1625 \mathrm{w}$ hen the buc caneer Pierre B elain, sieur d'Esnambouc [Lord of E snambouc], $\mathrm{c}$ aptured the $\mathrm{s}$ mall i sland of S aintChristophe (now Saint Kitts). Upon his return to France, Pierre Belain convinced the Crown that the French government needed to establish further control in the Caribbean, and to this end the buccaneer returned to Saint-Christophe, whence he led expeditions to the neighboring islands of Guadeloupe and Martinique, which led to them being officially annexed as French territories in 1635. Also, on the Greater Antilles island of Saint-Domingue, French adventurers, buccaneers, and pirates began to settle to breed cattle and grow tobacco, and later, the much more profitable sugar. B efore of ficial F rench government c ontrol w as exerted over S aint-Domingue in 1655, however, these i ndependent $\mathrm{c}$ olonists be gan $\mathrm{t}$ o i mport bl ack s laves from A frica. T he 1 abor intensive nature of sugar production required continued importation of ever increasing numbers of African workers into Saint-Domingue and other French Caribbean possessions. ${ }^{81}$

By the eighteenth century and the time of Juan de Chourio, the European French response to A fricans on the European mainland was beginning to change from one of benign neglect to concern. $\mathrm{T}$ he philosophes were out raged $\mathrm{b}$ y some of $\mathrm{t}$ he a buses pe rpetuated $\mathrm{b} y$ fellow Frenchmen upon A frican s laves in the $\mathrm{C}$ aribbean. $\mathrm{T}$ he philosophes believed in the i nherent equality of all men, and proclaimed this to the world. Thus the philosophes, through a campaign of public awareness, began the first abolitionist crusade. Nevertheless, it should be noted that in the i nitial pha se of $t$ he $\mathrm{m}$ ovement, $\mathrm{t}$ he philosophes did not a dvocate $\mathrm{f}$ or $\mathrm{t}$ he i mmediate

\footnotetext{
${ }^{80}$ Ibid., xxi.

${ }^{81}$ Ibid., xxii.
} 
emancipation of bl ack Caribbean s laves, but $r$ ather a $t$ ransitional em ancipation $b$ ased o $n t h e$ economic and political needs of the emerging French colonial state. ${ }^{82}$

Moreover, t here w as al so a s harp co ntrast $b$ etween $h$ ow the French $t$ reated $b$ lacks in Africa and those in the Caribbean. In Africa, Frenchmen were more likely to treat the blacks, or at 1 east $t$ heir 1 eaders, $w$ ith d eference. ${ }^{83}$ The A fricans $w$ ere al ready $u$ sed t $o$ t rading $w$ ith $t$ he Portuguese. For over o ne hundr ed years be fore the F rench arrived in West A frica, A fricans knew how to evaluate potential European clients and were both clever and intuitive in striking bargains. William B. Cohen said that the French merchants, "accustomed to cheating both their masters at home and the Africans with whom they traded, were surprised to meet their match in Africa." 84 These F rench traders quickly realized that co mmercial, military, political and ev en religious missionary inroads could m ore likely be a chieved by treating the black leadership as equals. T herefore, in A frica the European ar ea of co ntrol w as limited to c oastal r egions and dependent upon the good will and collaboration of African leaders. This forced the European to tread 1 ightly. However, in the m ore rigid plantation s ocieties of the $\mathrm{C}$ aribbean or the Indian Ocean, there were sufficient controls in place to subdue or at least contain any rebellions, with the European in total control of a small and unarmed island population.

While the general public in seventeenth and eighteenth century Europe could rarely see beyond the blackness of an A frican's skin, her or his lack of Christian faith and strange social customs, it is not s urprising that the typical un educated E uropean would de velop s ingle a nd stereotypical concepts a pplicable t o all b lack p eople. H owever, i t d oes s eem $\mathrm{t}$ hat a m ore

\footnotetext{
${ }^{82}$ Ibid., 69. W hile s ome of the philosophes at times depicted the b lacks a s "noble," at o ther times they would portrayed them as "savage," and therefore in need of guidance and redemption. This placed an aura of beneficence around the in stitution of slavery that it $\mathrm{c}$ ertainly did not merit. C ohen implies the origins of European positivism and $\mathrm{r}$ acism $\mathrm{r}$ ested in these musings of $\mathrm{t}$ he philosophes, an $\mathrm{d} t$ hat $\mathrm{t}$ his, i $\mathrm{t} \mathrm{tun}$, d elayed the $\mathrm{t}$ otal d eclaration of emancipation throughout the French colonial world.

${ }^{83}$ Ibid., xxiii.

${ }^{84}$ Ibid., 21.
} 
pragmatic, but hu man, vi ew of the A frican continent and $\mathrm{i}$ ts pe ople $\mathrm{w}$ as be ginning to e merge among the elites, and e ven to trickle dow $n$ to s ome w ith a e ven limited e ducation. ${ }^{85}$ Mark Kurlansky, an a uthority on B asque culture and hi story, stated that as far back as the sixteenth century, when most Europeans were focused on their particular region, country and crown, the successful Basque w as a " $m$ an of the w orld." ${ }^{86}$ Kurlansky ad ds that the B asque $\mathrm{m}$ an "was interested i n Africa and A sia, and es pecially p assionate about the lands Basques cal led Amerika." ${ }^{87}$ Chourio, growing up in the Pays Basque of France, was certainly such a man of the world, in the truest sense of the word.

Chourio's a ttitudes $t$ oward A fricans $m$ ay a lso ha ve b een $s$ haped $b$ y hi s pe rsonal observations on the treatment of blacks in France itself. The blacks that he saw in France were mostly from coastal West Africa. Despite the fragmentary nature of these observations, he may have met both Moslems and animists, and people hailing from large, extensive city-states, small city states and even stateless (acephalous) societies. ${ }^{88}$ The more he observed various Africans in Europe, the more difficult it be came to affix s tereotypes a bout bl ack people. Desiring a life dedicated $\mathrm{t}$ o $\mathrm{m}$ aritime commerce, $\mathrm{t}$ he young Chourio pr obably read va rious a ccounts of European explorers i $\mathrm{n}$ di stant pa rts of $\mathrm{t}$ he world, i ncluding A frica. $\mathrm{T}$ he $\mathrm{F}$ rench royal cartographer pe nned these c omments a bout the A frican c ontinent in 1666 , a $\mathrm{n}$ a ccount $\mathrm{t}$ hat Chourio may have read in his youth: "Every day reveals to us what the ancients did not know; it shows us that the greatest heat of A frica is also acco mpanied by some cool weather... that the animals are not so dangerous that the men cannot de fend themselves, that the $m$ en are not so

\footnotetext{
${ }^{85}$ Ibid., 27.

${ }^{86}$ Mark Kurlansky, The Basque History of the World (New York: Walker Books, 1999), 103.

${ }^{87}$ Ibid.

${ }^{88}$ Cohen, French Encounter, 26.
} 
faithless that there is no trade or human relations between them and foreigners; that the dragons, their serpents, their griffins, etc., are mostly imaginary ones." 89

Chourio also had to contend with the fact that slavery had long since be en abolished in France $\mathrm{p}$ roper, an $\mathrm{d} \mathrm{w}$ as co nsidered $\mathrm{i}$ llegal. In 1571 , w hen a $\mathrm{s}$ lave $\mathrm{s}$ hip ow ner $\mathrm{pl}$ aced s ome captured A fricans on t he a uction bl ock in B ordeaux (French Basque territory), the Parlement ordered that they all be immediately released, as slavery did not exist as an institution within the French realm; an 120 years later, another s lave s hip cap tain $w$ as required to free all of $h$ is vessel's human cargo when it docked in a French port. ${ }^{90}$ Therefore, when a French planter from the Antilles would arrive in France with a black domestic, he or she had to be set free. Cohen speculates that the French legal apparatus failed to face the contradiction of freedom for blacks in F rance, but permitting their enslavement beyond the metropole, by rationalizing that slavery was considered only a "temporary aberration," and not an enduring institution. ${ }^{91}$

For its part, the French government only tolerated the slave trade, insofar as it picked up the slack caused by the lack of white settlement in the Caribbean. The French Crown wanted to secure some portions of the Caribbean and circum-Caribbean as a base to launch forays against the ba stions of ot her E uropean pow ers in the a rea. A s 1 ate a s 1699 , $t$ he g overnor of S aintDomingue, $\mathrm{Du}$ Casse, had declared that it was not the revenue gained for the crown from the export of staple items from the island that made it so valuable, but rather its militarily strategic location, whence it could be ut ilized as a springboard for uni ting the French m onarchy w ith Mexico, $\mathrm{P}$ eru a nd the Kingdom of $\mathrm{S}$ anta Fé ( present da y Colombia). ${ }^{92}$ The Fr ench C rown authorities would have preferred to carry out Caribbean colonization efforts with the importation

\footnotetext{
${ }^{89}$ Nicholas $\mathrm{S}$ anson, L'Afrique et plusieurs cartes nouvelles et exactes et en divers traictés de géographie et d'historie (Paris, 1666), n.p.

${ }^{90}$ Shelby T. McCloy, The Negro in France (Lexington: University of Kentucky Press, 1961), 12.

${ }^{91}$ Cohen, French Encounter, 46.

${ }^{92}$ Quoted in Pierre de Vaissière, Saint-Domingue: La Société, 1629-1789 (Paris, 1909), 16.
} 
of more white indentured servants (engagés). The king had even issued a decree in 1686 stating that the black slave population could not exceed the total number of white indentured servants on the island of Saint-Domingue, but it proved unenforceable. ${ }^{93}$ For even though the law prescribed the e qual t reatment of i ndentured s ervants and slaves, $t$ he $\mathrm{pl}$ anters $\mathrm{c}$ ould onl $\mathrm{y}$ count on $\mathrm{t}$ he services of the indentured s ervants for a limite $d \mathrm{~d}$ uration, w hile the imp orted A fricans w ere required to remain in their charge for the to tality of th eir lives. A lso, the planters tended to mistreat the indentured servants more than the slaves, since an A frican slave was much more expensive to purchase than the limited service of an engagé. ${ }^{94}$ As word of the mistreatment of white $\mathrm{men}$ in the Caribbean r eached French shores, and as the continued deportation of white workers from F rench s oil $\mathrm{w}$ as a lso c ausing 1 abor s hortages on t he home front, a pol itical c ry went up $\mathrm{t}$ hroughout France for an e nd $\mathrm{t}$ o the engagé system. ${ }^{95}$ So d espite s ome French differentiation as to the le gal s tatus of $\mathrm{s}$ laves in s ociety, the $\mathrm{c}$ rown $\mathrm{w}$ as a ble to ju stify the continuation of s laves b eyond the m etropole ba sed on $t$ he e conomic $g$ ains a ccrued to F rance itself.

\section{Chourio and Slavery}

Whether Chourio was able to see beyond the inherent contradictions of the French Crown slave policy is still a matter of conjecture, but there are various indications that he subscribed to some of the racial views held by French colonists in the Caribbean that blacks from some areas of A frica w ere $\mathrm{m}$ ore s uitable f or $\mathrm{c}$ ertain ki nds of $\mathrm{w}$ ork than ot hers. Many of the s upposed differences be tween black groups in the Caribbean were based on a mythology created by the planter class. Nevertheless, these differentiations reveal a willingness a mong some Frenchmen to look at A fricans in a context be yond that of being the mere constituents of a hom ogenous

\footnotetext{
${ }^{93}$ Cohen, French Encounter, 47.

${ }^{94}$ Ibid., 38.

95 Ibid.
} 
category from whence sundry and pu rely negative generalizations could be made. Among the planters, it was believed that the Bambaras were best suited for labor, while the cleanest were the cattle-herding $\mathrm{p}$ eoples of $\mathrm{t}$ he $\mathrm{S}$ enegambia $\mathrm{r}$ egion, e steemed $\mathrm{f}$ itter $\mathrm{f}$ or pos itions a s hous ehold slaves or craftsmen. Many of the assumptions made by French colonial planters were based on at least a sparse knowledge of these ethnicities in Africa. The planters knew, for example, that the Aradas were born into a s lave c lass in A frica, and he nce they w ould probably e ncounter little resistance from them once transported to the Caribbean. Additionally, they were aware that the Mine people, back in A frica, w ere nomadic and could probably not be counted on t o be good tillers of the soil. ${ }^{96}$

Chourio, being a "man of the world" and seeking a life in trans-Atlantic commerce, most likely $m$ ade it a point to find out a s m uch a s possible a bout va rious A frican groups, at 1 east insofar as their pros and cons for accomplishing sundry tasks of colonization in the New World. Chourio $\mathrm{r}$ ealized $\mathrm{t}$ hat $\mathrm{m}$ any $\mathrm{E}$ uropeans also $\mathrm{f}$ eared $\mathrm{A}$ fricans, $\mathrm{a}$ nd $\mathrm{h}$ e us ed $\mathrm{t}$ his $\mathrm{f}$ act to $\mathrm{h}$ is advantage. A ccording to s ome European medieval traditions, Satan was a black man. He was sometimes referred to as the "black horseman" or the "Great Negro," leading his dark minions in nefarious activities. ${ }^{97}$ Seeing that Chourio's father circulated in diplomatic cliques, there is one particular cas e that the young Chourio was probably aware of wherein this fear of blacks was strategically employed to gain a political edge. In 1644, the French ambassador went to Munster in or der to c onduct pe ace negotiations w ith a S panish de legation. In this s o-called "p rotocol war" with $t$ he $\mathrm{S}$ panish, $\mathrm{t}$ he $\mathrm{F}$ rench $\mathrm{w}$ on $\mathrm{t}$ he $\mathrm{d}$ ay, for upon $\mathrm{s}$ eeing $\mathrm{t}$ he $\mathrm{F}$ rench ambassador

\footnotetext{
${ }^{96}$ Jean-Baptiste Labat, Nouvelle relation de l'Afrique occidentale, T. 4 (Paris, 1728), 87. The Aradas and Mine were some of the African ethnic groups ascribed certain characteristics as workers by Labat. .

${ }^{97}$ Ignacy Sachs, «L'Image du noir dans l'art européen, » Annales, économies, civilisations, sociétés 4 (May-June 1969) : 886.
} 
accompanied by a contingent of 140 black troops, the Spanish became "horrified," immediately capitulated and scurried out of town. ${ }^{98}$

Chourio was also ke enly aware of the reputation for military prowess gained by certain African groups both in Europe and the New World. While his primary financial interest was the exportation of cacao from Venezuela to Europe, two factors were throwing up obstacles in the accomplishment of this objective: the stronger British presence and Native American uprisings. The importation of a black fighting force into the emerging cacao production areas in the region of Perijá was going to solve both of these problems.

Chourio, by pur chasing the abandoned plantations a nd placing them in his ow na me and that of his son-in-law, Manuel Garcia Peña, and by keeping the 600 A fricans for himself in order $\mathrm{t}$ o $\mathrm{w}$ ork o $\mathrm{n}$ as well as $\mathrm{d}$ efend the recently bou ght $\mathrm{pl}$ antations, a ssured a $\mathrm{t}$ echnical compliance, at least, with the provisions of the Treaty of Utrecht, and avoided potential troubles later on w ith Philip V and the S panish royal court. T he S panish King had no di fficulties with Chourio regarding his intended goals of conquering the rebelling Native American factions and implanting a $\mathrm{C}$ apuchin mis sion in $\mathrm{P}$ erijá. $\mathrm{H}$ e was $\mathrm{c}$ oncerned th at $\mathrm{C}$ hourio's a ctivities w ith Africans and the slave trade might put him in some hot water with Queen Anne, hence the repeal of permission order issued by him to Chourio on 31 July $1722 .{ }^{99}$

Unsatisfied that his colonial authorities had acted sufficiently in carrying out his order of 31 July 1722, the King issued a nother royal order on 11 A pril 1729 i n which he decreed the seizure of all of Chourio's property, for the fraud that Chourio had allegedly committed in his transactions in illicit trade. ${ }^{100}$ In addition, the King stated that he would initiate an investigation

\footnotetext{
${ }^{98}$ Cohen, French Encounter, 15.

${ }^{99}$ See footnote 72 .

${ }^{100}$ Diccionario de la Historia Venezuela, $2^{\text {nd }}$ ed., Marianela Ponce, s.v. “Chourio, Juan de Iturbide,” ed. Manuel Rodríguez Campos (Caracas: Fundación Polar, 1997), I:804.
} 
against Chourio based on allegations that the captain was not a Spanish subject by birth and that his commercial activities in the Spanish colonies were only serving the interests of the French nation.

After some exhaustive investigations by royal officials from Santo Domingo, Cartagena and $\mathrm{M}$ aracaibo, however, the $\mathrm{K}$ ing 1 ater pr omulgated a ne $\mathrm{w}$ or der $\mathrm{i} \mathrm{n} w$ hich $\mathrm{C}$ hourio $\mathrm{w}$ as rehabilitated in the eyes of the Spanish court. On June 27, 1732, Chourio was authorized to take a ship to transport his cocoa harvest, and his license was extended for six more years to complete the pacification of the Motilones. He was also granted a company of $100 \mathrm{~s}$ oldiers to carry out the task, but he died without completing it. By that time, however, he had pacified four villages of the Maco tribe. The King granted another extension for three more years to his heirs, so that the mission could be satisfactorily concluded, along with the promise of cancelling the costs of military escorts and other debts previously incurred by Chourio. Then, in 1735, a newer order also expressed the King's satisfaction with the services provided by Chourio, referring to him in the context of a loyal vassal and providing no r eference to him as a F renchman or a foreigner. The Royal O rder to D on J uan C hourio, issued at San L orenzo, Spain, on 27 O ctober 1735, follows. ${ }^{101}$

The $\mathrm{K}$ ing $\mathrm{t} \mathrm{o} \mathrm{D}$ on $\mathrm{J}$ uan $\mathrm{C}$ hourio, $\mathrm{t}$ he pr incipal i ndividual $\mathrm{r}$ esponsible $\mathrm{f}$ or $\mathrm{t}$ he pacification and population of the valleys and lands of Perijá, in the province of Maracaibo y la Grita:

It $\mathrm{h}$ as $\mathrm{c}$ ome $\mathrm{t}$ o $\mathrm{m}$ y attention $\mathrm{t}$ he ha rdships that ha ve $\mathrm{b}$ efallen your en deavors because of the r ebellious Indians (Native A mericans) in the province, a nd the reasonable $\mathrm{m}$ ethods you ha ve $\mathrm{t}$ aken $\mathrm{t}$ o a ccomplish your a ssigned mission. Finding yourself $\mathrm{c}$ onfronted $\mathrm{w}$ ith a $\mathrm{n}$ a rmed pe ople, you t ook the proportionate methods $t o$ di scourage them. A $t$ a di fficult $t$ ime, D on $J$ uan de V alderrama, governor of $\mathrm{t}$ his province, $\mathrm{w}$ ent out $\mathrm{w}$ ith a $\mathrm{n}$ a rmed $\mathrm{c}$ ontingent $\mathrm{t} \mathrm{o} \mathrm{c}$ onfront $\mathrm{the}$ Motilones, a tribe causing many problems in the area. Along with this contingent

\footnotetext{
${ }^{101}$ Miguel de Villanueva, Secretary to the Spanish King, to Captain Juan de Chourio, 27 October 1735, Archivo Histórico Nacional de Colombia (Ciudades de Venezuela), Catálogo R-3:185-186, R -6:66-84, P ublic Library, Mérida, Venezuela.
} 
came a group of previously pacified na tives. You have $t$ aken these a ctions to preserve all that we have built up so far, in compliance with the contract that I previously granted you f or s aid pa cification and popul ation of $t$ hese va lleys wherein $t$ he na tives are f ound, $t$ hat $s$ aid $n$ atives $s$ hould de velop $a b$ ond of friendship $w$ ith the S panish s ettlers. O verall, I a $\mathrm{m} v$ ery satisfied, $\mathrm{p}$ rincipally viewing your de termined e fforts, unde rtaken $\mathrm{w}$ ith $\mathrm{g}$ reat $\mathrm{C}$ hristian $\mathrm{z}$ eal. $\mathrm{Y}$ ou diligently s trove to obt ain a s atisfactory c onclusion, i .e. c ontaining threats and pacifying the native population. Under the light yoke of our Holy Catholic Faith, hoping to endure to the end of this mission, it is $\mathrm{m} y$ s incerest de sire to s ee all united under Our Mother the Church. T hrough your on going efforts, it will be revealed, without a doubt, that we could not have come this far without you. I appreciate your honest endeavors on my behalf and how well you have performed this task. B e assured that your work was as much in God's service as it was in mine. I hope to s oon s ee the materialization of many good things from this, as you have given me good reason to believe. At this time I express my gratitude to you for your zealous efforts in my royal service.

Given at San Lorenzo this $27^{\text {th }}$ of October 1735, I, the King, by the grace of God.

-Don Miguel de Villanueva

Secretary to the Consejo de Indias (Council of the Americas)

\section{Conclusions}

What ma kes $\mathrm{C}$ hourio a $\mathrm{n}$ imp ressive figure for his time $\mathrm{w}$ as the in tricate la byrinth of Trans-Atlantic connections. His birth in a Basque country without self government, divided in loyalties $\mathrm{b}$ etween $\mathrm{S}$ pain a nd France; $\mathrm{h}$ is o perations o $\mathrm{f} b$ oth le gal and illegal trading i $\mathrm{n} t$ he Caribbean and C ircum-Caribbean regions of the Dutch, F rench, and S panish colonies; and his conflicts $w$ ith the B ritish following the T reaty of $U$ trecht, all these $p$ lacing $h$ im as a ma $n$ of contradictions s tanding at the ep icenter of $\mathrm{t}$ he late s eventeenth a nd e arly e ighteenth century Trans-Atlantic world. Chourio also had to reconcile an emerging consciousness about the value of Africans as both workers and human beings, with a prevailing Eurocentric notion that ascribed them a $\mathrm{n}$ in ferior $\mathrm{s}$ tatus. It $\mathrm{i} \mathrm{s} \mathrm{cl}$ ear $\mathrm{t}$ hat $\mathrm{t}$ he French an $\mathrm{d}$ Dutch, an $\mathrm{d} t \mathrm{o}$ a $\mathrm{l}$ esser ex tent, $\mathrm{t}$ he Portuguese, had more enlightened views and policies toward Africans and that Chourio looked upon Africans as more than a slave class. 
Chourio liv ed in a $\mathrm{n}$ a ge $\mathrm{w}$ hen me rcantilism $\mathrm{w}$ as $\mathrm{d}$ ying o ut. $\mathrm{M}$ ilitary $\mathrm{t}$ actics a nd engagements on the high seas were giving way to the development and quest for new economic advantages. $\mathrm{P}$ owerful forces of co mmercial ca pitalism w ere $t$ ransforming the T rans-Atlantic world, and Chourio was poised to benefit handsomely from this process. His chief obs tacle to increased profits a nd the a ccumulation of wealth, how ever, w ere the m eddling British. Like African slaves, indentured servants and indigenous peoples connected with Britain's acquisition of new commodity markets and commercial expansion, the merchants outside the British sphere of influence found themselves pushed to the margins of the society.

The late seventeenth cen tury and early eighteenth cen tury Trans-Atlantic world appears to have been much less homogenous than previously assumed, and the life of Jean de Chourio e Iturbide epitomizes this. 


\section{CHAPTER THREE}

\section{AFRICAN ROOTS AND EUROPEAN INFLUENCE IN THE SUR DEL LAGO}

\section{Introduction}

This c hapter e xamines the A frican or igins of va rious a spects of the A fro-Venezuelan culture, mo st particularly its milita rization and cultural practices ma nifest in the S ur del Lago region in Zulia state. S ome of the original black inhabitants of this zone have been traced back to various Imbangala peoples in pre-colonial Angola. This chapter, therefore, examines what we know about Angola in the light of those assertions made by Juan de Dios Martínez Suarez that the A fro-Zulian c ontingent brought to V enezuela by J uan de Chourio or iginated in Imbangala lands and with Imbangala peoples.

This chapter includes an overview of Angola's geography pertinent to the situation and movement of Imbangala peoples, as well as Imbangala cultural and political influences that may have $\mathrm{c}$ arried ove $\mathrm{r} \mathrm{t}$ o $\mathrm{V}$ enezuela. A dditionally, $\mathrm{t}$ hose $\mathrm{c}$ onnections $\mathrm{w}$ ith $\mathrm{C}$ hourio a re $\mathrm{m}$ ore intimately detailed. A s pre-colonial Angola was primarily under the prevue of the Portuguese, how was it pos sible for a Basque-French slave trader to find his way there? A nd furthermore, how and why could contact between Chourio and the Imbangala come about? To answer these questions, $\mathrm{m}$ otivations are $\mathrm{s}$ ought i $\mathrm{n}$ a $11 \mathrm{c}$ orners of $\mathrm{t}$ he $\mathrm{T}$ rans-Atlantic $\mathrm{w}$ orld: th e F rench penetration of A frica, Imbangala in stitutions a nd de sire for E uropean contact ( to i nclude the conduct of the slave trade in Angola), as well as efforts by the Spanish a uthorities in the New World to s uppress indigenous hos tilities and recurring insurrections. T his chapter attempts to establish these pertinent connections between the Afro-Zulian contingent of Juan de Chourio and the Imbangala of Angola, thereby lending support, if not vindication, to the claims advanced by Juan de Dios Martínez Suarez. 
Martínez states that the first enslaved Africans to arrive in Venezuela were brought over by the German Weslers in 1528, a nd many thousands more were transported in the succeeding years of Venezuelan history, to include those in the Sur del Lago Maracaibo community. All of the A frican-derived people brought to the shores of Venezuela form the nucleus of the present and expansive A fro-Venezuelan community. B ut Martínez, in his work with the Sur del Lago blacks, also asserts that there exists in Northwestern Venezuela a unique Afro-Zulian culture that needs to be recognized both nationally and beyond. To this end, he established the Ajé Group in 1982. He hoped that the group would help to preserve and publicize Afro-Zulian culture through a promotion of, and awareness concerning, the chimbánguele and gaita drum rhythms, among other cultural, linguistic ${ }^{1}$ and religious expressions.

Martínez, born in 1945 in the Sur del Lago community of Bobures, was encouraged to study about his origins from an early age by his grandmother, and has since published seventy books replete with village myths, legends and music. A s of 2004, there were more than 9,000 children in 300 schools of the Sur del Lago learning to appreciate their cultural patrimony, due to the groundwork established by Martínez. ${ }^{2}$ Clearly then, Martínez has followed in the traditions of Lévi-Strauss. Like the French structuralist who observed and wrote about the Nambikwara of the Brazilian rainforest, Martínez has meticulously documented as many aspects of the lives of the Afro-Zulians as he could, from sexual relations and the construction of shelters to diets, pets and sundry occupations. From both Lévi-Strauss and Martínez, one garners that the distinctions between the cognitive processes of the so-called "primitive mind" and its modern and "civilized" counterpart may be fewer than some would care to think. It is always preferable to look at the

\footnotetext{
${ }^{1}$ Carrillo, "En la tierra de los hijos de Ajé," Panorama. "In the daily speech of Zulians, Juan de Dios Martínez has idenitified 3,000 words of African origin. Among these are lora (wound), bemba (think lips), jojoto (corn), timba (stomach), bululú (chaos, disorder), and tufo (bad odor)."

${ }^{2}$ Darryn Mijares, Afro-Zulian preserves black identity symbolized in Chimbánguele drums and gaita, http://www.vheadline.com/printer_news.asp?id=21761 (27 June 2004).
} 
familiar as if it were foreign, and search for the familiar in what appears to be decidedly foreign. ${ }^{3}$ That is the basis of structural anthropology, and one of the tenets by which Martínez carried out his life's work. While the theories of Martínez provide anthropological scaffolding with respect to the Afro-Zulian community, this dissertation augments it with needed historical material upon which others can build.

\section{Angola: The Geographic Setting}

In order to gain further understanding, it is important to briefly examine what we know about Angola and the regions round about it in Central and Southwest Africa. As the Imbangala culture $\mathrm{c}$ an trace its o rigins to the nor theastern L unda r egions (Norte and Sul) of Angola, i ts significance is highlighted in the rapid territorial Imbangala expansion, especially in a westerly direction to the coast at Cabinda and the mouth of the Congo River, where it was conceivable that they encountered the French and other non-Portuguese Europeans in the time of Chourio's asiento.

\footnotetext{
${ }^{3}$ Larry Rohter, "Other Voyages In the Shadow of Lévi-Strauss," New York Times, Thursday, 5 November 2009. This article noted the passing of the French structural anthropologist, who lived one month short of 101 years.
} 
Map 3.1: Geophysical map of Angola.

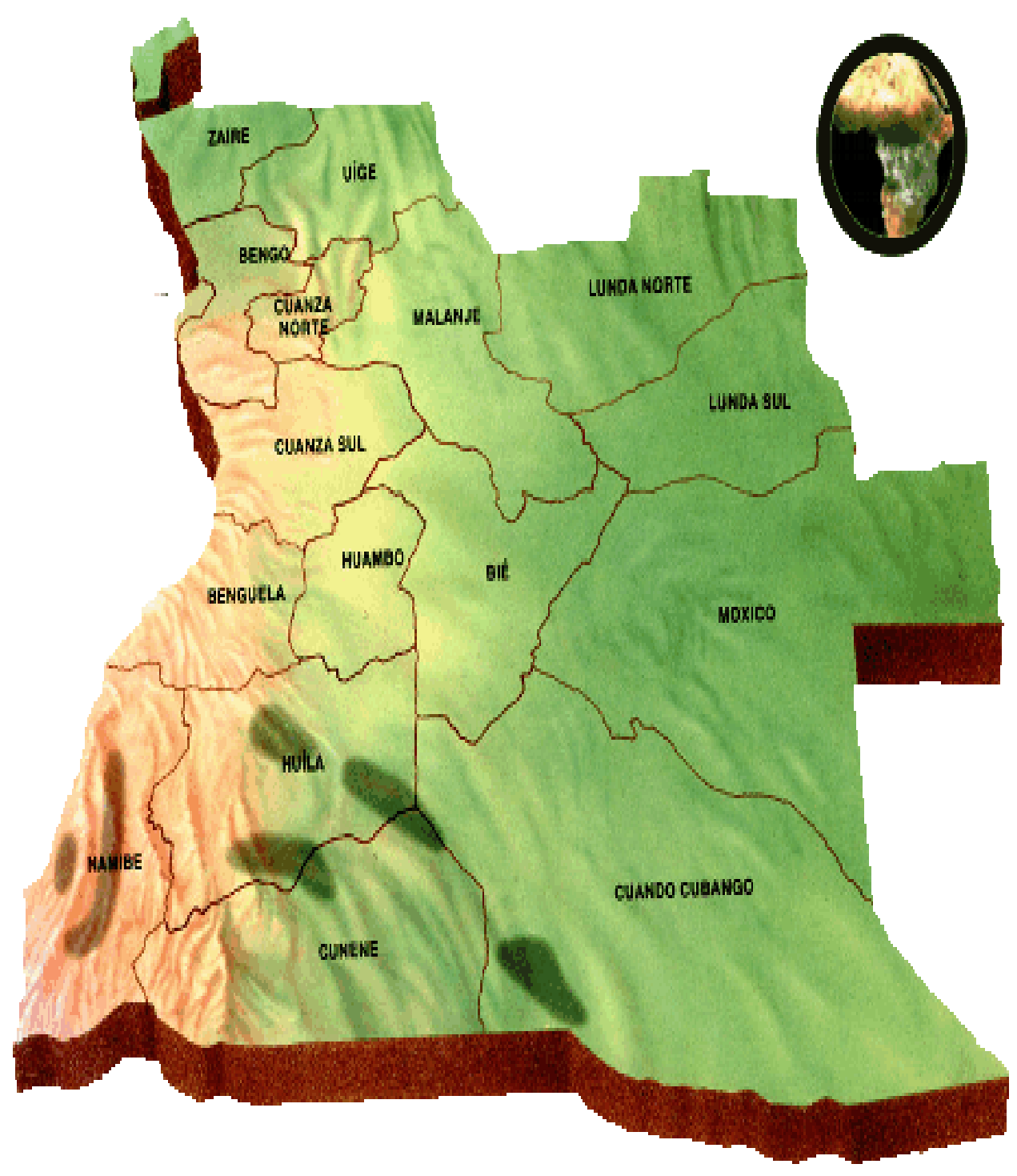

Note the contemporary states of Lunda Norte and Lunda Sul in the northeast. The borders of these two states roughly correspond to the original Imbangala lands.

http://luandamap.com/map/angola/Angola_1.gif

The a rea of contemporary Angola, including the Cabinda Enclave, is 1,246,700 s quare kilometers. The country of Angola constitutes an integral part of the Central Africa region, that also $\mathrm{c}$ onsists of a $11 \mathrm{or}$ part of $\mathrm{t}$ he $\mathrm{c}$ ontemporary nations of $\mathrm{C}$ ameroon, $\mathrm{t}$ he $\mathrm{C}$ entral African 
Republic, the Congo, Equatorial Guinea, Gabon, Zaire, Zambia, and the offshore island republic of São Tomé and Principe.

The largest geographic feature in Angola is the Central Plateau, partly edged in the west by mountains that extend out from the coastal lowlands. Altitudes in this area reach more than 2,500 meters, such as in the Benguela-Bié Plateau in its center and the Humpata Highlands in the south. The northern regions of this plateau, dubbed the planalto by Portuguese colonists, reach the coastal fringe in a gradual slope. E lsewhere, this descent is more precipitous. The coastal lowlands va ry i $\mathrm{n} w$ idth $\mathrm{f}$ rom $\mathrm{t}$ wenty-five ki lometers, $\mathrm{c}$ loser $\mathrm{t}$ o $\mathrm{B}$ enguela, t o $\mathrm{m}$ ore $\mathrm{t}$ han one hundred fifty kilometers in the Cuanza River Valley, which is situated immediately to the south of Luanda, then capital of the country. ${ }^{4}$

\footnotetext{
${ }^{4}$ Irving Kaplan, Angola: A Country Study (Washington, District of Columbia: The American University, 1979, $2^{\text {nd }}$ ed., orig. ed. 1967), 60.
} 
Map 3.2: Contemporary map of Angola depicts major cities and river systems.

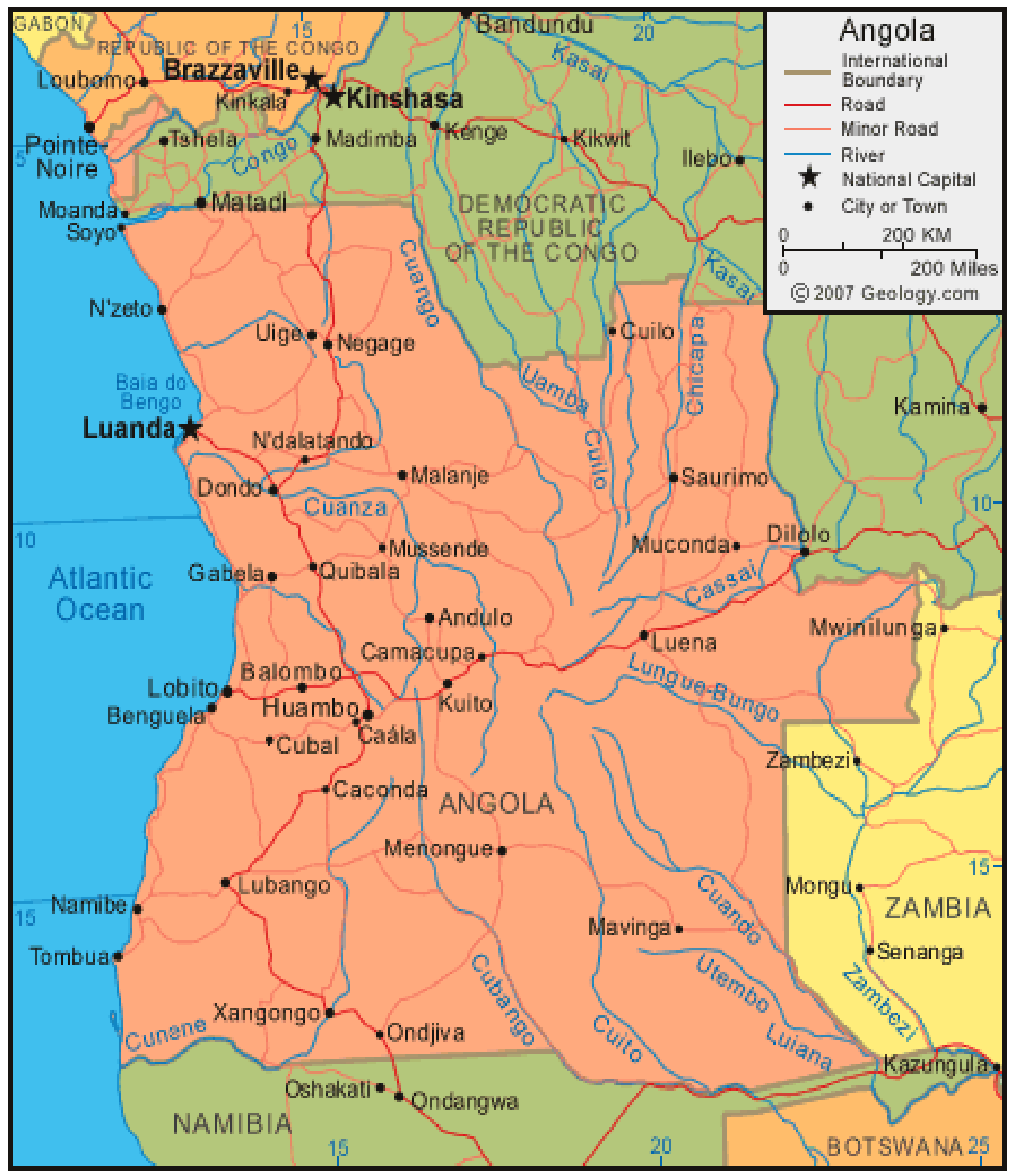

Source: http://geology.com/world/angola-map.gif

Because of the cold a nd nor th-flowing Benguela $\mathrm{C}$ urrent $\mathrm{j}$ ust of $\mathrm{f}$ the s horeline in the Atlantic Ocean, precipitation is minimal in the coastal lowlands. This region is quite arid, and especially so in the areas south of the port of Benguela, which forms a northern extension of the 
Namib Desert that the locals refer to as the Moçâmedes. T he av erage altitude of the planalto ranges b etween one thousand and on e thousand e ight hund red $m$ eters; and ve getation on $t$ his plateau is varied. On the savanna, sparsely distributed baobabs and acacias are noted. A nd in the higher area of the plateau's western perimeter, where the greatest amount of precipitation can be found, a $n$ e xpansive de ciduous forest ha s t aken $r$ oot ove $r$ the $m$ illennia. In the no rthern reaches of the tropical savanna, however, a plethora of elephant grass can be found, interspersed with yet more baobab trees. But in the Humpata Highlands, no natural forest cover exists. Only in the Mayombe Hills in the northeast of the Cabinda Enclave, ${ }^{5}$ adjacent to the Congo River, are extensive tropical rain forests to be found. Nevertheless, this delicate ecosphere has significantly diminished over time due to heavy commercial logging operations. ${ }^{6}$

As far as climate goes, Angola's differs little from the rest of Sub-Saharan West Africa, having clearly defined and alternate rainy and dry seasons. In the north, the rainy season can last from $\mathrm{S}$ eptember or $\mathrm{O}$ ctober $\mathrm{t} \mathrm{o}$ A pril or $\mathrm{M}$ ay. A nd in $\mathrm{t}$ he $\mathrm{s}$ outh, $\mathrm{t}$ he rainy s eason $\mathrm{s}$ tarts in November or December, but only lasts for three or four months. Rain is usually more intense in the nor th, especially in the hi gher interior pl ateau $\mathrm{r}$ egions. $\mathrm{T}$ emperatures a lso $\mathrm{d}$ ecrease $\mathrm{w}$ ith distance from the equator and higher altitudes. And they increase with proximity to the Atlantic Ocean. For example, at S oyo ne ar the mouth of the Congo River, the median temperature is approximately 26 degrees $\mathrm{C}$, but drops to 16 de grees $\mathrm{C}$ at Huambo in the Central Plateau. The coolest $\mathrm{m}$ onths a re July and A ugust, a lso the d riest s eason, and sometimes frost $\mathrm{c}$ an even be found in the higher altitudes. ${ }^{7}$

\footnotetext{
${ }^{5}$ In both maps in this $\mathrm{c}$ hapter, the Cabinda Enclave $\mathrm{c}$ an be indentified as the noncontiguous Angolan territory situated on the Atlantic coast to the south of the Republic of the Congo and to the north of the Democratic Republic of the Congo.

${ }^{6}$ Kaplan, A Country Study, 61.

${ }^{7}$ Ibid., 64 .
} 


\section{Geography and Political Formation in the Pre-Colonial Era}

Apart from those features d ealing $\mathrm{w}$ ith $\mathrm{v}$ arious as pects of $\mathrm{t}$ he $\mathrm{p}$ hysical landscape and climate, there are also elements of human geography to consider. In Central Africa, for example, a diverse array of political formations was organized in the pre-colonial era.

These new structures were based on patterns of land usage. In the northeastern lands of Angola and interior a reas immediately s outh of the Congo River, for example, patterns of 1 and us age proved conducive to the formation of numerous chieftaincies whereby each settlement coalesced and uni ted a round a s ingle $\mathrm{s}$ trongman. $\mathrm{O}$ ver $\mathrm{t}$ ime, hi s he irs $\mathrm{w}$ ould $\mathrm{r}$ ule in hi s na me, w hich converted into a title of leadership. The people maintained themselves largely through farming and $\mathrm{f}$ ishing, a nd a lso $\mathrm{h}$ unted $\mathrm{f}$ rom $\mathrm{t}$ ime $\mathrm{t} \mathrm{o} t$ ime on $\mathrm{t}$ he va cant $\mathrm{t}$ racts of 1 and $\mathrm{b}$ etween $\mathrm{t}$ he settlements. $\mathrm{T}$ he $\mathrm{r}$ evenues $\mathrm{f}$ rom th $\mathrm{e} \mathrm{s}$ alt a nd me tal tr ading $\mathrm{p}$ rovided tr ibute to $\mathrm{c}$ entral governments and cemented economic relations with other chieftaincies to form a $\mathrm{v}$ ast regional trade network among the sundry Bantu-speaking groups of Central Africa.

One of the kingdoms of particular importance to the political formation of the Imbangala was that of the $\mathrm{Luba}^{8}$ in w hat is now the province of $\mathrm{S}$ haba in the ne ighboring D emocratic Republic of the Congo. In pre-colonial times it was known as Katanga and is strategically placed in the Lualaba lakes region. ${ }^{9}$ Since the fourth c entury it has be en popul ated by i ron-working farmers. The people of the upper Lualaba, who were the ancestors of the modern Luba, were the most proficient smelters of both iron and copper in the region. Luba land was also well endowed with salt, as well as metal resources, an d they were always willing to trade with ne ighboring

\footnotetext{
${ }^{8}$ All information on the Luba d erived from Thomas Q. Reefe, Rainbow and the Kings: A History of the Luba Empire to 1891 (Berkeley: University of California P ress, 1981), as well as $\mathrm{N}$ daywel è $\mathrm{N}$ ziem, "The political system of the Luba and Lunda: its e mergence and expansion" (Chapter 20), in Africa from the Sixteenth to the Eighteenth Century, UNESCO General History of Africa, Vol. V, ed. B. A. Ogot (London: Heinemann, 1992), 588607.

${ }^{9}$ Ibid., 59. S haba is sometimes referred to as Katanga; and the Democratic Republic of the Congo is the former nation of Zaire. $\mathrm{T}$ his is mentioned to a void c onfusion with the contemporary R epublic of the Congo, which is directly north of Angola's Cabinda extension. See the map at the beginning of this chapter.
} 
kingdoms. This trade, in turn, encouraged the mixing of populations and the emergence of large towns all along the trade routes. ${ }^{10}$ Because of the long dry seasons, however, the quality of the soils was marginal and the best lands were confined to the river valleys. Thus, the topography lent itself to patterns in which groups of people dwelt on these limited tracts of fertile land, with vast $\mathrm{s}$ tretches of $\mathrm{u}$ ninhabited te rrain in b etween s ettlements. M ost lik ely, it $\mathrm{w}$ as the limite $\mathrm{d}$ availability of suitable lands that led to the formation of Imbangala political structures as groups splintered off from this region, moving north, south and west.

\section{The Imbangala}

The Imbangala $w$ ere co mmunities of $\mathrm{n}$ omadic $\mathrm{w}$ arriors $\mathrm{w}$ ho inhabited the $\mathrm{c}$ entral and northern interior regions of Angola since at least before 1600 and lived by pillage. ${ }^{11}$ The earliest Western acco unt o $\mathrm{ft}$ he Imbangala $\mathrm{d}$ ates $\mathrm{b}$ ack $\mathrm{t}$ o $\mathrm{t}$ he 1 ate $\mathrm{s}$ ixteenth and ear ly s eventeenth centuries. B etween 1590 a nd 1610 a n English sailor, A ndrew B attell, liv ed in C entral West Africa. ${ }^{12}$ He was in the Angolan interior until 1607 and on the Loango coast for the remaining three years. In pe rsonal a ccounts related to English s cribes upon hi s return to "civilization," Battell provided details of his life among a band of the Imbangala known as the Jaga, with whom he claims to have resided for approximately twenty months out of his twenty years in Central West Africa.

Everything that is know $\mathrm{n}$ a bout B attell's c hronology, or a bout Battell himself, c omes from the accounts rendered: $t$ hat as a young $\mathrm{m}$ an he left England in 1589 on a privateer for South America; that he was captured in Brazil and shipped to Angola the following year; that he

\footnotetext{
${ }^{10}$ Joel E. Tishkin, "Central Africa: Peoples and States" (Chapter 9), in African History Before 1858, Vol. 2, ed. Toyin Falola (Durham: Carolina Academic Press, 2000), 207-208.

${ }^{11}$ JanVansina, "The Kongo kingdom and its neighbors" (Chapter 19), in Africa from the Sixteenth to the Eighteenth Century, UNESCO General History of Africa, Vol. V, ed. B. A. Ogot (London: Heinemann, 1992), 558.

${ }^{12}$ Jan V ansina, "On Ravenstein's E dition of B attell's Adventures in Angola a nd L oango," History in Africa 34 (2007): 321.
} 
escaped to Loango in the S pring of 1607 on a r aft he had constructed hi mself; a nd that he returned to his hom etown of Leigh in England sometime in late 1610 or early $1611 .^{13}$ One of Battell's transcribers, Samuel Purchas, states that Battell referred to the Jaga as a "m ost warlike people," 14 and that they had gained a notorious reputation for their overrunning of neighboring countries. ${ }^{15}$ No doubt that B attell's a ccounts of the Imbangala added credence to the mythos surrounding their military prowess among the Europeans.

Since Battell, as far as is known, kept no journal or diary, the information gathered about pre-colonial Angola and the surrounding regions was based solely on his reminiscences. ${ }^{16}$ What makes hi s a ccount be lievable, how ever, i s the pl ethora of Bantu w ords that he e mployed. Despite th eir a trocious spelling, $\mathrm{t}$ he $\mathrm{m}$ ajority o $\mathrm{ft}$ hese $\mathrm{w}$ ords $\mathrm{w}$ ere $\mathrm{r}$ ecognized a $\mathrm{s}$ be ing of Mbundu origin. M ost notably, he recalls the ethnic names of "Imbangala" and "Gindes," even though a fter 1600 ne arly all Europeans referred to them as Jagas. N evertheless, the ethnonym "Imbangala" survived a s a s elf-designator, e ven t o this da y, while Gindes did not. ${ }^{17}$ E. G. Ravenstein's rendering is as follows: “He (Battell) saith they are called Iagges by the Portugals, by themselves Imbangolas." 18

Central West African historian Joseph C. Miller also attaches a high degree of credibility to Battell's account. He believes that that Battell's first contact with the Imbangala took place in 1601, when a Portuguese trading expedition to which Battell was attached encountered a band of the Imbangala moving north, attempting to cross the Kuvo, the largest river situated between the Cunene and the $\mathrm{C}$ uanza rivers. The $\mathrm{P}$ ortuguese a ssisted the Imbangala in c rossing the Kuvo

\footnotetext{
${ }^{13}$ Vansina, “On Ravenstein's,” 325.

${ }^{14}$ Ibid., 326.

${ }^{15}$ Ibid., 329.

${ }^{16}$ Ibid., 334.

${ }^{17}$ Ibid., 335 .

${ }^{18}$ Ibid., 342. From E. G. Ravenstein, Strange Adventures of Andrew Battell of Leigh (London, 1901), 983-984. This is a composite of two accounts of the life of Andrew Battell authored by Samuel Purchas and an anonymous writer in His Pilgrimage (London, 1613) and His Pilgrimes (London, 1625).
} 
River, in exchange for their assistance in capturing other Africans for the slave trade. ${ }^{19}$ It was at this p oint that the P ortuguese a ssigned $\mathrm{B}$ attell the mis sion of jo ining $\mathrm{w}$ ith the Imbangala and serving as an aide to their king. Battell thereby became especially close to the king o ver a sixteen $\mathrm{m}$ onth pe riod, $\mathrm{s}$ ince he $\mathrm{w}$ as a ble to secure hi $\mathrm{m}$ fine $\mathrm{g}$ ame $\mathrm{w}$ ith hi s $\mathrm{m}$ usket, a nd a lso attained some notoriety for his demonstrated marksmanship ability in field engagements against Imbangala enemies. ${ }^{20}$

Because accounts like Battell's were rare, establishing Central A frican chronologies is a difficult task for the historian. As a non-Western political and social organization, the Imbangala present some challenges to historians and researchers in related social sciences. In dealing with a society lik e th e Imbangala, $\mathrm{w}$ hose $\mathrm{h}$ istory is $\mathrm{p}$ rimarily $\mathrm{b}$ ased on or al da ta, $\mathrm{s}$ ubstantial qualifications are imposed on the affixing of dates to Central African events. The single datable occurrence which led to the search for a reliable chronology in early Central African history took place in the early seventeenth century. It was during that time that armies of highly trained Jaga warriors s wept westward a cross the Mbundu regions of northern Angola. T he descendants of these invaders, properly known as Imbangala rather than Jaga, maintain that their pe ople first arrived in A ngola und er the a stute 1 eadership of a r uler know n s imply as K inguri. ${ }^{21}$ Lunda $^{2}$ traditions, how ever, $\mathrm{s}$ tate $\mathrm{t}$ hat $\mathrm{K}$ inguri or iginated i $\mathrm{n} \mathrm{t}$ he $\mathrm{n}$ ascent Lunda $\mathrm{E}$ mpire i $\mathrm{n}$ Katanga. Therefore, Jan V ansina speculated that an approximate date for the establishment of the Lunda Empire might be made if the year in which Kinguri and the Imbangala first appeared in Angola could be determined. ${ }^{22}$ However, the lack of fieldwork clarifying the relation between structure

\footnotetext{
${ }^{19}$ Miller, "Imbangala," 564.

${ }^{20}$ Vansina, “On Ravenstein's,” 341.

${ }^{21}$ Presented as Kinguri when referring to a proper name, and kinguri when referring to a title holder's position.

${ }^{22}$ Miller, "Imbangala," 549.
} 
and $t$ radition among the Imbangala, a s w ell a s the g rowth a nd e xpansion of L uba political systems, made determining the arrival at specific or even approximate dates nearly impossible. ${ }^{23}$

Scholars in the twentieth century have grappled with the problem of dating pre-colonial African peoples. Joseph C. Miller, for example, traveled to Angola in 1969 whence he was able to draw on sundry traditions throughout the country and show that the figures described in oral histories, like kinguri, were actually permanent named titles in systems of positional succession and perpetual kinship. These are fundamental systems derived from the Lunda, with the result that all genealogies describe networks of perpetual titles related to each other by "fictional ties" rather than real, biological families. ${ }^{24}$

Thus, $\mathrm{t}$ hose " kings" $\mathrm{t}$ hat a re $\mathrm{m}$ entioned i $\mathrm{n} \mathrm{t}$ raditions do not represent particular individuals, but $r$ ather dynasties in a na med of fice. A ny reinterpretations of the traditions in terms of named positions will significantly alter the dating of not only Imbangala history, but the entire complex of Luba and Lunda states in Katanga as well. ${ }^{25}$

Both Imbangala and Lunda historians cite similar traditions, that Kinguri left his original home in $\mathrm{K}$ atanga a fter a dispute $\mathrm{w}$ ith $\mathrm{h}$ is $\mathrm{s}$ ister, Lueji, $\mathrm{r}$ egarding th $\mathrm{e}$ rights a nd privileges of Lunda royal authority. The sister won, and thence replaced their father as ruler of the Lunda and married a hunt er know $\mathrm{n}$ a s $\mathrm{C}$ ibinda Ilunga, who c ame from the $\mathrm{n}$ eighboring Luba K ingdom. They, i n c oncert, dr ove out $\mathrm{K}$ inguri, s ending him on a 1 ong w estward journey were he ultimately ran into the Portuguese. The structure of the Imbangala tradition indicates that both Kinguri and his sister were fictitious figures representing Lunda tubungu titles. These are the oldest know $n$ of $L$ unda pol itical $t$ itles, w hile Cibinda Ilunga e mbodied t he $\mathrm{L}$ uba f orms of political authority. Therefore, one could surmise that these traditions are metaphorical in nature,

\footnotetext{
${ }^{23}$ Ibid., 551.

24 Ibid.

${ }^{25}$ Ibid., 554.
} 
portraying Luba influence on the Lunda state while asserting that the kinguri title holders left in a state of opposition to the imposition of Luba control. It was in the context of this system that the office of kinguri continued to move westward out of the Luba-Lunda complex over a period of several lifetimes, with the title being transferred from one neighboring state to a nother. Miller declares that the title drifted from the Lunda through the Cokwe and Songo toward the west."26

Under n ew leadership, the Imbangala groups moved w est and fortified their pos itions, whence they be gan to s lowly d eploy in m any directions. T he Lunda traditions s ay that $\mathrm{t}$ he Imbangala moved at a leisurely pace. They hunted with bows and arrows, as well as snares and traps. U ltimately, Miller states, they planned on returning to their Lunda kinsmen in Katanga, but in the capacity of an army of liberation. T he kinguri and other newly titled leaders of the western Imbangala bands desired nothing more than to establish a new kingdom as a secure base of ope rations $\mathrm{w}$ hence $\mathrm{t}$ hey $\mathrm{c}$ ould $\mathrm{l}$ aunch a $\mathrm{n}$ a ttack on $\mathrm{t}$ he $\mathrm{L}$ uba us urpers oc cupying $\mathrm{t}$ heir traditional hom eland. ${ }^{27}$ That the w estward mo vement of the Imbangbala b rought th em in to closer contact with the Portuguese and various European interlopers in Angola and the Congo ultimately proved fortuitous to their mutual political agendas, as will be revealed in greater detail later in this chapter.

One of the more powerful Imbangala states in northern Angola was that of the Kasanje, imposed in Ndongo territory north of the Cuanza River, probably around $1630 .{ }^{28}$ According to Miller, Imbangala tr aditional histories a mong $\mathrm{t}$ his $\mathrm{g}$ roup pos ed a $\mathrm{n}$ additional pr oblem $\mathrm{f}$ or researchers, b ecause the Kasanje co nsistently displayed the tendency to retain only a s elected memory of past events. T he Kasanje conveniently s et as ide all of those ev ents that tended to delegitimize the structure of the Imbangala s tate; and as all of the s ubsequent Kasanje ch iefs

\footnotetext{
${ }^{26}$ Ibid., 552.

${ }^{27}$ Ibid., 554.

${ }^{28}$ Heintze, "Extraordinary Journey," 67.
} 
ruled in the Lunda position of the kinguri, the Imbangala traditions placed an emphasis on the title role of the kinguri in the foundation of the Kasanje state, to the absolute exclusion of all other titles, even those that other seventeenth century sources indicated were just as important. ${ }^{29}$

Seventeenth c entury s ources ab out the Imbangala s eem t o s hare o ne common factor: "Virtually without e xception th ey w ere w ritten by members of foreign, non -African cu ltures, who came to the area as conquerors, slave traders and missionaries." ${ }^{.30}$ Naturally, such sources would tend to be biased, but that is not the major problem. Of concern to Heintze is that the vast majority of these source authors never spent any significant amount of time in African courts, or even living among African peoples, where they would have taken advantage of the opportunity of becoming intimately acquainted with sundry aspects of Imbangala culture. Andrew Battell's case might, therefore, be considered a rare exception. The English sailor was not only able to observe e vents a s they transpired, but experience them on a pe rsonal level, di rectly from the inside of a n Imbangala camp. For this reason, Heintze a sserts, Battell's acco unt is af forded much more weight. ${ }^{31}$

Apart f rom th e s carcity of W estern in sider a ccounts lik e B attell's, e arly a ttempts to reconcile $\mathrm{C}$ okwe, Lunda and Imbangala publ ished traditions $\mathrm{w}$ ith $\mathrm{r}$ espect to the kinguri have availed little because they faltered on apparent contradictions. Miller correctly surmised that the "traditions of each ethnic group, those of the Imbangala included, recall only the events which affected their own political systems during the kinguri title's mo ve from Katanga to A ngola," adding that the "Cokwe, for example, remember developments which determined later political relations among their own kings, while the Imbangala emphasize other events which led to later

\footnotetext{
${ }^{29}$ Miller, “Imbangala," 552.

${ }^{30}$ Heintze, "Extraordinary Journey," 67-68.

${ }^{31}$ Ibid., 68.
} 
configurations of Lunda, Cokwe, and other titles in the mature kingdom of Kasanje."32 As a consequence, it can be said that the Ovimbundu and the Songo remember those stories that both the Cokwe and Imbangala have conveniently forgotten.

The politicizing of these stories also makes the task of the contemporary historian a more difficult one ; but M iller's s ystem of da ting, a s i t c ontains no implicit c hronology ba sed on assumed human life spans, may serve to mitigate against the propagandized histories rendered by many groups. And with respect to the Imbangala, the evidence leads one to believe that many years had e lapsed s ince the or igin of one Imbangala title in the na scent Lunda Empire and a successor's ap pearance on the co ast. D espite the f act t hat $\mathrm{s}$ ome $\mathrm{d}$ ocuments es tablish an Imbangala $\mathrm{p}$ resence i n Angola as early a s the $1560 \mathrm{~s}$, not hing i s r evealed c oncerning $\mathrm{t}$ hose preceding events further to the east in Katanga. Those events that shaped the formation of a later Imbangala kingdom may well have occurred decades or even centuries earlier. As such, Miller contends $\mathrm{t}$ hat $\mathrm{b} y$ extending $\mathrm{t}$ he $\mathrm{m}$ ethodological $\mathrm{t}$ echniques de veloped $\mathrm{f}$ or $\mathrm{t}$ he Imbangala traditions, i.e. applying permanent named titles to events instead of looking for the names of real persons to a ttach to pub lished Lunda histories, one c an logically s peculate that the Luba and Lunda kingdoms passed through several pe riods " before the stage previously a ssumed to have initiated the development of states in central Africa."33

As Imbangala groups began to branch off from this Luba-Lunda complex in Katanga, and move westward, they came into increased contact with Europeans and enhanced possibilities for trade. D avid Birmingham ha s e ven s uggested that the ope ning of the west c oast $t$ rade $w$ ith Europeans may have be en s parked by the establishment of the Lunda-Imbangala Empire. A $t$ first, many Lunda groups began a w estward migration. But over time, this pattern was replaced

\footnotetext{
${ }^{32}$ Miller, "Imbangala," 552-553.

${ }^{33}$ Ibid., 574.
} 
by a $\mathrm{n}$ ew Lunda-Imbangala e xpansion c onsisting of $\mathrm{c}$ entrally-controlled e xpeditions $\mathrm{t}$ hat established s atellite s tates a mong s urrounding peoples, dr awing them into th eir c ontinually expanding s phere o f i nfluence. $\mathrm{T}$ he $\mathrm{m}$ ost $\mathrm{s}$ ignificant a rea of expansion $\mathrm{w}$ as $\mathrm{t}$ oward $\mathrm{t}$ he northwest. Lunda-Imbangala dynasties were being set up on the middle Cassai, and also as far west as the lower Cuango. Birmingham speculates that this growth was directly proportional to the expansion of Dutch, English and French trade on the Loango coast north of the Congo River. By the 1 ate e ighteenth c entury, 20,000 s laves pe $r$ year w ere being s hipped out by these non Portuguese E uropean p owers. B irmingham d eclares that this $\mathrm{w}$ as a " $\mathrm{f}$ antastic $\mathrm{n}$ umber $\mathrm{w}$ hich could hardly be coming from the sparsely populated immediate vicinity." 34

Birmingham c oncludes that this i ncrease in the supply of s lave 1 abor m ust ha ve be en linked to a s ource de ep in the interior of Angola, be yond the lower Congo; and that both the expansion of the Lunda-Imbangala and growth of the Loango trade provided an effective stop to the further development of Portuguese slave trading enterprises in the region. ${ }^{35}$

This a ssessment a grees with P hyllis M. Martin, w ho s tates th at the te rm "Imbangala" derives from an Umbundu root word, "vangala," which signifies that one is "brave" or "wanders widely through the countryside." ${ }^{36}$ She explains that in the sixteenth century, Lunda title holders and their families began to migrate westward from their traditional homeland east of the Cuango. Upon their arrival in the lands of the Ovimbundu, these Lunda incorporated sundry Ovimbundu political a nd $\mathrm{s}$ ocial i deals. $\mathrm{F}$ rom $\mathrm{t}$ his $\mathrm{f}$ usion resulted a ne $\mathrm{w}$ hi storical pe riod, $\mathrm{t}$ hat of $\mathrm{t}$ he

\footnotetext{
${ }^{34}$ David Birmingham, "The African Response to Early Portuguese Activities in Angola," in Protest and Resistance in Angola and Brazil, ed. Ronald H. Chilcote (Berkeley: University of California Press, 1972), 27.

${ }^{35}$ Ibid.

${ }^{36}$ Phyllis M. Martin, Historical Dictionary of Angola (London: Scarecrow Press, 1980), 52, 73-74. Umbundu is the language of the $\mathrm{O}$ vimbundu, whose important s ubgroups include the $\mathrm{B}$ ailundu, B ieno, D ombe, $\mathrm{G}$ anda, $\mathrm{H}$ uambo (a.k.a. Wambu), Caconda, Chiyaka, Sambu and Sele. The Ovimbundu are contemporary Angola's largest ethnic group, and the name probably derived from a word applied in the Kongo for both the Mbundu and Ovimbundu. The Ovimbundu tr aditional lands a re s ituated i $\mathrm{nt}$ he fertile h ighlands o f entral Angola. $\mathrm{T}$ hey a re traditional agriculturalists and noted as excellent blacksmiths.
} 
Imbangala. This Lunda-Imbangala society organized itself into highly militarized, mobile bands that $r$ oved $f$ reely $t$ hrough $t$ he $r$ egion of Benguela a nd no rth $t$ o $t$ he Cuanza, pi llaging a nd terrorizing a $11 \mathrm{t}$ hey encountered. Before $\mathrm{t}$ he a rrival of $\mathrm{t}$ he $\mathrm{B}$ ritish, $\mathrm{D}$ utch a nd $\mathrm{F}$ rench, $\mathrm{t}$ he Imbangala also found it convenient to work with the Portuguese. In 1612 they even formed an alliance with them, and for the next $\mathrm{t}$ en years the P ortuguese and the Imbangala w ent a bout attacking an $\mathrm{d}$ en slaving the sedentary $\mathrm{M}$ bundu. ${ }^{37}$ This br ought the Ndongo a nd ne ighboring states t o the point of total collapse; a nd b y the s eventeenth c entury, the r esulting Imbangala conquest of, and fusion with the Mbundu, led to the rise of yet a new group of states in Angola, the Kasanje and Matamba. These endured until the nineteenth century. ${ }^{38}$

As a result of these movements and conquests, the Imbangala acculturated some of the ways of the $\mathrm{O}$ vimbundu, $\mathrm{M}$ bundu, a nd ot her groups a long $\mathrm{i}$ ts pa th of w estward e xpansion. Miller also concurs with both Birmingham and Martin with respect to the westward expansion of the Imbangala, and further explains that the ne ar-total c entralization of a uthority within th ese various Imbangala groups, he ld $\mathrm{i}$ ntact $\mathrm{t}$ hroughout $\mathrm{t}$ he $\mathrm{w}$ estward $\mathrm{dr}$ ive, $\mathrm{m}$ ade alliances $\mathrm{w}$ ith Europeans an attractive possibility for subordinate Imbangala holders of permanent titles. Based on limi ted in formation, $\mathrm{M}$ iller $\mathrm{s}$ urmises that $\mathrm{t}$ he Imbangala $\mathrm{p}$ olitical s tructure of the e arly seventeenth c entury p robably c onformed ni cely to the kulembe $e^{39}$ type, whereby a s ingle $\mathrm{k}$ ing held the only permanent and autonomous position of power within a band with all of the other

\footnotetext{
${ }^{37}$ Martin, Dictionary of Angola, 61. The language of the Mbundu is Kimbundu, and its subgroups consist of the Ambundu, Kisama, Libolo, Hako, Ndembu, Hungu, Jinga, Mbondo, Songo and Imbangala. The Mbundu occupy an area of north central Angola, and are principally situated in the districts of Luanda, Malanje and the North and South Cuanza. Today, the Mbundu constitute the second largest ethnic group in Angola. They are mainly agriculturalists, craftsmen and traders.

${ }_{38}^{38}$ Martin, Dictionary of Angola, 52.

${ }^{39}$ Joseph C. Miller, Kings and Kinsmen (Oxford: C larendon Press, 1976), 89. The kulembe is a shadowy line of kings who $\mathrm{cl}$ aimed au thority o ver $\mathrm{p}$ ortions o $\mathrm{ft}$ he $\mathrm{B}$ enguela $\mathrm{p}$ lateau several ce nturies $\mathrm{b}$ efore $\mathrm{t}$ he $\mathrm{O}$ vimbundu kingdoms in that region were established.
} 
chiefs being appointed in accordance with the $v u n g a^{40}$ model. Therefore, Miller believes that the formal structure of the kilombo divided the members of each Imbangala band into about a dozen sections, with each under the leadership of its own captain. These regiments us ually lived and fought separately from each other, although there were separate entrances for each group into the war c amp. T he cl ustering of r egiments in the same kilombo was for the pur pose of de fense augmentation, although distinctiveness within each regiment was preserved. ${ }^{41}$

These militarized groups of the Lunda-Imbangala w ere considered the major pur veyors of slave labor in the Trans-Atlantic slave trade, and also served as mercenaries for the Europeans at various times in Africa and abroad. ${ }^{42}$ The sundry Imbangala groups were intensely focused on a cult of war. Any survivors would be taken as prisoners of war. The young men in good health would be ke pt and trained as Imbangala fighters, while the ot hers w ould be sold of f to other African ki ngdoms or vi llages, w hence the D utch, F rench, $\mathrm{P}$ ortuguese or ot her s lavers c ould purchase them.

By 1600 some of the Imbangala groups are believed to have gone as far west as to reach the shores of the Atlantic Ocean, and some historians suggest that one group, the Kasanje, may have even reached the Luanda a rea be fore 1576. A fter 1600, how ever, the Imbangala became well entrenched throughout the entire Cuango Valley. It was here that they became tenacious middlemen in the growing trade between Lunda and the Portuguese coastal settlements up and down the length of Angola. The principal and legal slave trade was through Mbundu territory to the Imbangala controlled states of the middle Cuango region, Matamba and Kasanje, which, in turn, $\mathrm{t}$ raded $\mathrm{w}$ ith $\mathrm{t}$ he $\mathrm{L}$ unda dom ains $\mathrm{f}$ urther $\mathrm{t} \mathrm{o}$ the $\mathrm{e}$ ast. $\mathrm{T}$ he $\mathrm{m}$ ost $\mathrm{s}$ erious $\mathrm{t}$ hreat $\mathrm{t} \mathrm{o} t$ he

\footnotetext{
${ }^{40}$ Ibid. The vunga embodied a co ncept of au thority s tructurally o pposed to the hereditary titles a warded to the lineages of the ngola a kiluanje as it introduced for the first time a type of position situated outside of the control of the descent groups.

${ }^{41}$ Ibid., 183.

${ }^{42}$ Martin, Dictionary of Angola, 59.
} 
Portuguese $t$ rade $\mathrm{w}$ as $\mathrm{t}$ he nor thern $\mathrm{r}$ oute $\mathrm{s}$ tarting from $\mathrm{t}$ he $\mathrm{M}$ iddle $\mathrm{C}$ uango $\mathrm{t}$ hrough $\mathrm{C}$ ongo territory $\mathrm{t}$ o $\mathrm{t}$ he por ts, such a $\mathrm{s} \mathrm{C}$ abinda, $\mathrm{w}$ here $\mathrm{D}$ utch, $\mathrm{E}$ nglish a nd $\mathrm{F}$ rench $\mathrm{s}$ lave $\mathrm{t}$ raders predominated. ${ }^{43}$ The Imbangala were fiercely opposed to Portuguese penetration and their trade monopoly of the interior, and sought European allies in their struggle with them. The Kasanje kingdom $\mathrm{w}$ as a ble to hold itself t ogether unt il the pe riod of $1911-1913$, when it w as finally subdued milita rily by the P ortuguese. It is from th is h istorical foundation that the Imbangala remained a significant factor in the both the history of Angola and the New World. ${ }^{44}$

\section{Encounter with the Europeans}

The $\mathrm{w}$ estward $\mathrm{m}$ ovement of $\mathrm{t}$ he Imbangala br ought $\mathrm{t}$ hem $\mathrm{i} \mathrm{nc}$ ontact $\mathrm{w}$ ith $\mathrm{t}$ he interventionist activities of the Portuguese, whose contact with the people of sub-Saharan West Africa be gan in 1443. Their initial forays to A frica were made with the purpose of obtaining gold, $s$ laves a nd ot her valuable $\mathrm{c}$ ommodities for $\mathrm{t}$ rade in $\mathrm{E}$ uropean $\mathrm{m}$ arkets. $\mathrm{T}$ he $\mathrm{f}$ irst $\mathrm{f}$ ew expeditions $\mathrm{w}$ ere e ssentially not hing $\mathrm{m}$ ore $\mathrm{t}$ han $\mathrm{r}$ aiding parties of $\mathrm{c}$ oastal $\mathrm{s}$ ettlements. $\mathrm{T}$ he Portuguese soon learned, however, that in order to maximize the profitability of further African ventures, they would need the assistance of at least some of the local chiefs. Their permission and $\mathrm{c}$ ooperation $\mathrm{w}$ ith $\mathrm{t}$ he Portuguese $\mathrm{w}$ ould not $\mathrm{c}$ ome $\mathrm{c}$ heaply; but $\mathrm{t}$ he $\mathrm{c}$ ementing of these alliances early on gave the Portuguese a distinct advantage over other European powers seeking commercial expansion in Africa. Henceforth, the British, Dutch, French and Spanish had to deal directly with the Portuguese if they wanted to conduct any kind of business in A frica. A nd to legitimize these operations and also to contain the trade within the context of a royal monopoly, the Portuguese monarchs negotiated treaties with accessible African sovereigns, such as the king of Kongo. T his also enabled the establishment of trading factories under the purview of royal

\footnotetext{
${ }^{43}$ Martin, Historical Dictionary, 84.

${ }^{44}$ René Pélissier and Douglas L. Wheeler, Angola (New York : Praeger Publishers, Inc., 1971), 23, 25.
} 
factors. These individuals served as a gents and represented bot $\mathrm{h}$ the diplomatic and e conomic interests of the Portuguese crown. B y the close of the fifteenth c entury most of the $\mathrm{W}$ estern European nations had recognized Portugal's sovereignty in all matters pertaining to West African trade, especially since the signing of a Castilian-Portuguese accord over Africa in 1479 that gave Portugal uncontested control in that continent. ${ }^{45}$

The Portuguese knew that if they wanted to maintain control of A frica they would have to be gin a process of settlement. T hus, they be gan to popul ate the Cape Verde Islands in the 1460 s, a nd, j ust twenty years la ter, in itiated th e c olonization of s ome islands in the Gulf of Guinea. T he P ortuguese $\mathrm{c}$ rown e ncouraged the settlers in a gricultural pursuits. B y the first quarter of the sixteenth c entury, sugar p rocessing w as underway in S ão Tomé, as w ell as the production of cotton and the manufacture of cloth in the Cape Verde Islands for trade with the West A frican mainland. B oth of these commercial $v$ entures $m$ et $w$ ith s ome s uccess, an $d$ this served to spur on further trade with the African mainland. The Cape Verdians soon crossed over to the continent to conduct trade with A fricans in the rivers of upper Guinea, while Portuguese from São Tomé founded a trading post on an island off the mainland that would later become the site for the city of Luanda, later the capital of Angola. ${ }^{46}$

It $\mathrm{w}$ as not unt il the establishment of Luanda in 1567, a nd the p romising reports o $\mathrm{n}$ Angola emanating from the expeditions of the Portuguese navigator Paulo Dias de Novais, that those lands south of the Congo River occupied some interest in Lisbon's royal court. By 1600, the territory known as Angola eclipsed the Congo as the most important area for the Portuguese on the African continent. B ut whereas the Portuguese felt obligated to follow peaceful policies of al liance an d cultural as similation in the Congo, they c ame to be lieve that in Angola direct

\footnotetext{
${ }^{45}$ Malyn Newitt, Portugal in Africa: The Last Hundred Years (London: Longman Group, Limited, 1981), 1. ${ }^{46}$ Ibid.
} 
military action would be required in order to impose Lisbon's authority over the sobas, or chiefs. In the $\mathrm{C}$ ongo, the ruler know $\mathrm{n}$ a $\mathrm{s}$ the manicongo reigned $\mathrm{s}$ upreme. $\mathrm{S}$ ince he embraced the customs, religion, slave trade and traditions of the Portuguese, no further diplomatic or military initiatives were needed on the part of P ortugal. O $\mathrm{n}$ the ot her hand, the Angolan chiefs could never arrive at a consensus. Many were opposed to the southward expansion of the slave trade. There was already some inkling of the horrors that this peculiar institution would wreak on their society. And inasmuch as the chiefs could not be co-opted, direct Portuguese governance would have to be imposed by force of arms if the emerging Trans-Atlantic slave trade was to receive protection and prosper. $^{47}$

By the beginning of the seventeenth century, however, the Portuguese-Spanish monopoly of the A frican s lave trade w as s tarting to br eak dow n. ${ }^{48}$ Recalling th e Castilian-Portuguese African accords reached in 1479, it is remarkable that this Iberian monopoly lasted as long as it did. $\mathrm{T}$ he British, $\mathrm{D}$ utch a nd $\mathrm{F}$ rench $\mathrm{w}$ ere all $\mathrm{s}$ eeking t o e xpand bot $\mathrm{h} t$ heir e conomic a nd territorial dom inions, a nd obt aining a foothold $\mathrm{i} n \mathrm{~A}$ frica $\mathrm{w}$ ould provide $\mathrm{t}$ he $\mathrm{m}$ eans of accomplishment. W hile th e D utch tr ied to mimic th e P ortuguese in e stablishing c oastal fortifications, the $\mathrm{B}$ ritish and French pos itioned themselves as interlopers. Both British and French slavers would maneuver their ships clear of the large Portuguese fleets; or, if necessary, fight their way through s maller P ortuguese c onvoys. U pon arriving in A frican $\mathrm{w}$ aters, $\mathrm{they}$ anchored offshore just long enough to sell their goods, as well as to barter for or purchase gold, ivory or s laves. $^{49}$ These A frican $\mathrm{t}$ rading en terprises $\mathrm{w}$ ere either s ponsored b y a $\mathrm{E}$ uropean government or financed by wealthy European merchants. ${ }^{50}$

\footnotetext{
${ }^{47}$ James Duffy, Portuguese Africa (Cambridge: Harvard University Press, 1959), 49.

${ }^{48}$ Basil Davidson, Black Mother: The Years of the African Slave Trade (Boston: Atlantic Monthly Press, 1961), 52.

${ }^{49}$ Ibid., 53.

${ }^{50}$ Ibid., 54.
} 
From the s tart, how ever, A frican c oastal p eoples did not know what to make of these often w arring ne wcomers from E urope. T hey were not $\mathrm{s}$ ure of either their m ethods or their motives. They also did not understand how any of the profits garnered by the Europeans were realized a nd di stributed. $\mathrm{N}$ evertheless, $\mathrm{t}$ he $\mathrm{c}$ oastal $\mathrm{A}$ fricans $\mathrm{s}$ oon $\mathrm{c}$ ame $\mathrm{t}$ o $\mathrm{t}$ erms $\mathrm{w}$ ith the strangers, working out an intricate s ystem of bu siness protocol, c urrencies, taxing and trading jargon. "The slave trade," according to Basil Davidson, "was grafted little by little into a living nexus of commercial needs and appetites and habits." ${ }^{51}$

Therefore, by the seventeenth c entury, Portugal's dominance of the W est A frican slave trade $\mathrm{w}$ as s lipping a way, be ing $\mathrm{c}$ rowded out $\mathrm{b}$ t these ot her $\mathrm{E}$ uropeans. $\mathrm{M}$ iller be lieves that Portugal's grip on the slave trade started to slip for the following reasons: 1) Brokers of higher quality f oreign goods b egan $\mathrm{t}$ rading for s laves in A ngola and ot her $\mathrm{p}$ arts of the $\mathrm{P}$ ortuguese African empire; 2 ) The waning process acc elerated when the Portuguese prime minister, the Marquis of $\mathrm{P}$ ombal, unde rtook na tionalistic e fforts t o de velop $\mathrm{m}$ ore dom estic i ndustries an $\mathrm{d}$ trade, thus di verting a ttention and investment from P ortugal's overseas dominions; 3) What Portuguese investments were b eing $m$ ade in o verseas v entures w ere $n$ ow m ostly $r$ elegated to Brazilian development; and 4) W hat little Portuguese capital remained for s laving ope rations was a lso being tr ansferred to B razil, where the Crown s till e njoyed some s uccess in limiting contraband slaving activities. ${ }^{52}$

And during this same period, Spanish power in the West Indies was also starting to wane. In the cas es of both the Portuguese and the Spanish, it was the British, Dutch and French who were pr ojecting $\mathrm{t}$ he $\mathrm{m}$ ajor $\mathrm{c}$ ounterforce $\mathrm{t} \mathrm{o} \mathrm{t}$ heir i nfluence a nd $\mathrm{c}$ ontrol on bot $\mathrm{h} \mathrm{s}$ ides of the Atlantic Ocean. The loss of islands in the Caribbean to other European powers suffered by the

\footnotetext{
${ }^{51}$ Ibid., 55 .

52 Joseph C. Miller, Way of Death: Merchant Capitalism and the Angolan Slave Trade, 1730-1830 (Madison: University of Wisconsin Press, 1988), xx.
} 
Spanish $t$ hroughout $t$ he $t$ imeframe of $t$ he $s$ eventeenth $\mathrm{c}$ entury $\mathrm{w}$ as qui te e xtensive. ${ }^{53}$ For example, G reat Britain acquired Bermuda (1609), S t. C hristopher (1623), B arbados and the Leeward Islands ( 1625); F rance a cquired $\mathrm{G}$ uadeloupe ( 1626), a nd M artinique ( 1635); $\mathrm{t}$ he Netherland a cquired C uraçao, S t. E ustatius a nd T obago (1630s); a nd Denmark a cquired S t. Thomas (1671).

Of $g$ reater s ignificance, this i ntensive E uropean pe netration of the $\mathrm{N}$ ew World $g$ ave a new impetus to the Trans-Atlantic slave trade. Prior to the seventeenth century, the interloping nations' s ole interest in Africa ha d be en the c onveyance of s laves from c oastal a reas of that continent t o S panish po ssessions in the Caribbean or t o the P ortuguese c ontrolled c olony of Brazil. While they continued to supply slaves to these areas throughout the seventeenth century, they henceforth had to fill any and all demands for slaves made by their own respective nation's countrymen, a new settler class on the aforementioned Caribbean islands. ${ }^{54}$

On these islands tobacco, rum, coffee and cotton were important exports; but the greatest generator of profits from these new colonies was "King Sugar." 55 Of course, the new planters could never produce enough sugar to satisfy the ever-increasing demands for it emanating from Europe; a nd s o t hey d eveloped a $\mathrm{n}$ e xtreme $\mathrm{d}$ ependency on $\mathrm{t}$ he A frican s lave $\mathrm{t}$ rade. A nd according to Davidson, sugar production was such a labor intensive op eration that whole slave populations had to be replenished "time after time." 56

And of all the European pow ers invested in sugar production in the Caribbean, France was foremost. S ugar w as first introduced into the F rench W est Indies in 1640, a nd by 1660 , France was i mporting s o much $\mathrm{W}$ est Indian raw sugar an $\mathrm{d}$ h ad es tablished s uch an ex tensive

\footnotetext{
${ }^{53}$ Davidson, Black Mother, 58.

${ }^{54}$ Ibid., 58, 59.

55 Ibid., 59.

56 Ibid.
} 
network of refineries for it, that they were able to export this product to the rest of Europe. The demand for more African slave labor was so great that the French government felt obligated to break the slavery monopoly of its ow $\mathrm{n}$ s ponsored F rench W est Indian Company, and in 1670 issued a royal or der that opened up the A frican slave trade to any Frenchman who w ished to engage in it. ${ }^{57}$ It was the desire of the French king, declared the order, to advance in every way possible "the trade in blacks from Guinea to the islands [of the Caribbean].... There is nothing that does more to help the growth of those colonies.... than the labor of blacks.. 58

This was quite a turn about for F rench pol icy respecting slavery, for up unt il the early $1600 s$, the $F$ rench $s$ tayed clear of t he $s$ lave $t$ rade. In $f$ act, $F$ rench cr own $p$ olicy s pecifically condemned it. According to a royal proclamation issued in 1571, "France, the mother of liberty, permits no s laves." In addition, a French legal dictum of $1607 \mathrm{r}$ einforced the previously cited proclamation, de claring that, "All pe rsons a re free in this kingdom: A s s oon as a s lave has reached these frontiers, and become baptized, he is free." Insofar as France and s ome of the states of coastal West A frica were concerned, a p rofitable and thriving maritime exchange was developing in gold, ivory, pepper and palm oil, free of the undue influence of the Portuguese and the slave trade. ${ }^{59}$ The European lust for sugar changed all of this, and the resulting demands for the importation of more black slaves from Africa to work the plantations in the Caribbean.

Therefore, a s a r esult of the F rench $r$ oyal or der of $1670, t$ he $F$ rench enslavement of Africans grew by 1 eaps a nd bounds of intense e nterprise. F rom 1670 t o 1672, F rench ships carried A frican s laves a cross the A tlantic Ocean at an unprecedented rate of $m$ ore than three thousand per year. Nevertheless, Basil Davidson asserts that this was still far less than during the

\footnotetext{
${ }^{57}$ Ibid., 59, 60 .

${ }^{58}$ Ibid., 60. Davidson obt ained these pa rtial qu otations from $\mathrm{G}$ aston-Martin, Historie de l'Esclavage dans les Colonies Françaises (Paris: Presses Universitaires de France, 1948), pages not specified.

${ }^{59}$ Davidson obtained quotations from Gaston-Martin, Historie de l'Esclavage, pages not specified. Ibid., 43-44.
} 
years of tremendous commercial expansion in these endeavors that would begin for France, and hence for Juan Chourio, in the eighteenth century. ${ }^{60}$

The A fricans transported to the New World during this second wave at the close of the seventeenth and be ginnings of the e ighteenth centuries $w$ ere of $m$ ore di verse or igins, a nd the number reaching the South American mainland increased exponentially. According to Leslie B. Rout, Jr., a historian of the African Diaspora, the following regions of A frica were exploited as sources for s lave labor on the S outh A merican continent: U pper Guinea, Lower Guinea, the Congo River Delta and Angola, and Mozambique. ${ }^{61}$ The Upper Guinea region consists of the contemporary nations of Senegal, Gambia, Guinea, the Republic of Guinea Bissau, Sierra Leone, Liberia and the western part of Mali. The Lower Guinea consists of the lands fronting the Gulf of Guinea, including the Bights of Benin and Biafra. This territory was formed by the presentday African s tates of G hana, T ogo, Benin, Nigeria and the nor thern pa rt of $\mathrm{C}$ ameroon. $\mathrm{T}$ he Congo River Delta and Angola region consists of all the land e ncompassing the m outh of the Congo River that now belongs to the nations of the Congo, Gabon and Angola. And lastly, the Mozambique region c onsists of the contemporary nation of M ozambique, an ex-possession of Portugal on the southeast African coast.

And of all the regions noted above, the greatest source of Africans for South America was Angola. R out states that, "Juan Rodríguez Cutiño, the second major Portuguese asentista, was governor of Angola, and thus there was little question of the origin of the blacks he shipped to the New World. Especially after 1600, these castas [ethnicities] of Angola, subcategorized as loandas, bengueles, congos and manicongos, w ere shipped in quantity to almost every area of

\footnotetext{
${ }^{60}$ Ibid., 60 .

${ }^{61}$ Leslie B. Rout, Jr., African Experience in Spanish America (Cambridge: Cambridge University Press, 1976), 28.
} 
the Spanish Indies." 62 Therefore, those A fricans of the Congo River Delta and Angola regions of Africa apparently constituted the most numerous population group among all black ethnicities of African origin in Venezuela. ${ }^{63}$

\section{The Activities of the French Guinea Company}

The demand for African slaves in the New World in the eighteenth century was so great that quotas could never be reached by the various chartered monopoly companies. As noted in Chapter Two, the Compagnie Française de Guinée (French Guinean Company) was awarded the asiento, or m onopoly c ontract, to de liver 4,800 A fricans a nnually to S panish A merica for ten years, starting in 1702; and the British Royal South Sea Company won a contract with Spain in 1713, at the signing of the Treaty of Utrecht, to supply African slaves to Spanish colonies in the Americas and the Caribbean for the next thirty years. $\mathrm{N}$ either of these contractual obligations was fully m et. H owever, be tween these t wo asiento companies, 89,031 A frican s laves w ere transported to Spanish America by 1739. The Anglo-Spanish contract would have continued for another four years, but the so-called War of J enkins Ear effectively ended the British asiento's trading activities. ${ }^{64}$

Just one year a fter the s igning of the Treaty of Utrecht, r epresentatives of the British Royal S outh S ea C ompany b egan t o c omplain about t he F rench $\mathrm{G}$ uinea $\mathrm{C}$ ompany's t rading activities with the Spanish. Colin Palmer estimates that the French Guinea Company had at least twenty-seven ships trading with the Spanish in $1714 .{ }^{65}$ Of this situation, one British company

\footnotetext{
${ }^{62}$ Ibid., 30 .

${ }^{63}$ A detailed summary of Afro-Venezuelan ethnic origins is found in the following chapters.

${ }^{64}$ Colin A. Palmer, Bondage Studies in Slavery and the Slave Trade (Madison: University of Wisconsin, 1986), 27.

${ }^{65}$ Ibid, 29.
} 
official noted that, "the French lower the prices of goods and carry the riches of the whole Indies into their domains."

The $\mathrm{F}$ rench $\mathrm{G}$ uinea $\mathrm{C}$ ompany, for $\mathrm{t}$ he $\mathrm{m}$ ost pa rt, s ucceeded in $\mathrm{s}$ atisfying a $\mathrm{t} l$ east $\mathrm{t}$ he minimum needs for A frican labor by the colonists in Spanish America, having brought 19,269 Africans there from 1703-1715. ${ }^{67}$ It accomplished this by creating a bureaucratic machine in the Spanish colonies that facilitated the conduct of the s lave trade. T he French Guinea Company established factories in Santo D omingo, Cartagena, Porto Bello, P anamá, Havana and Buenos Aires. A lso, the company a ppointed a gents for $\mathrm{M}$ aracaibo, $\mathrm{C}$ aracas, $\mathrm{R}$ ío de $\mathrm{la} \mathrm{H}$ acha, $\mathrm{S}$ anta Martá, $\mathrm{C}$ umaná, $\mathrm{P}$ uerto $\mathrm{R}$ ico, $\mathrm{P}$ uerto $\mathrm{B}$ ello, $\mathrm{V}$ era $\mathrm{C}$ ruz, $\mathrm{M}$ argarita an $\mathrm{d} \mathrm{G}$ uatemala. $\mathrm{T}$ hese factories $\mathrm{w}$ ere $\mathrm{s}$ taffed $\mathrm{b}$ y a $\mathrm{p}$ resident or governor, a $\mathrm{n}$ a ccountant, one or $\mathrm{t}$ wo a gents a nd a secretary. $\mathrm{T}$ he agent(s) us ually $\mathrm{d}$ eployed $\mathrm{w}$ ith $\mathrm{t}$ he $\mathrm{s}$ hips $\mathrm{t} \mathrm{o} \mathrm{w}$ atch over a nd conduct $\mathrm{t}$ he company's business, but all the individuals involved shared in the responsibility of receiving and selling the African slaves to the Spanish, and insuring that the contraband trade was minimized. ${ }^{68}$

Up unt il the W ar of the Spanish Succession, F rance w as comfortable in her control of these vast slave trading operations. And even after the decreed loss of the asiento by the French and $\mathrm{i}$ ts $\mathrm{t}$ ransference $\mathrm{t}$ o $\mathrm{B}$ ritish $\mathrm{c}$ ontrol $\mathrm{f}$ ollowing $\mathrm{t}$ he $\mathrm{T}$ reaty of $\mathrm{U}$ trecht, $\mathrm{t}$ he $\mathrm{F}$ rench $\mathrm{G}$ uinea Company s till $\mathrm{c}$ arried o $\mathrm{n}$ its $\mathrm{r}$ ole o $\mathrm{f}$ in troducing $\mathrm{A}$ frican $\mathrm{s}$ laves in to $\mathrm{S}$ panish A merica, a lbeit sporadically. The of ficers of the French Guinea Company insisted that their or ganization w as not in vi olation of the treaty b ecause it ha d not met its a nnual obligations in the previous ten years, and therefore retained the right to sell African slaves to the Spanish until its entire contract

\footnotetext{
${ }^{66}$ Ibid.

${ }^{67}$ Ibid., 34.

${ }^{68}$ Ibid., 29. Ships from the asiento companies were frequently stocked with goods for the contraband trade. Says Palmer: "One widespread practice was to put a few slaves on board a ship to 'qualify' it as en gaged in the slave trade, thereby assuring its admission to a Spanish port. Once the ship had sold its slaves and the other goods it introduced illicitly, it would then purchase Spanish commodities with the proceeds from the sale." The Spanish crown tried, with little success, to end this contraband trade and even appealed on occasion to the companies for help in these matters.
} 
had been fulfilled. And a ccording to Palmer, Porto Bello received most of the French Guinea Company's slaves, followed by Cartagena and Buenos Aires. ${ }^{69}$

To understand this expansion of French slaving activities on bot h sides of the Atlantic, the origins of the French Guinea Company need to be examined. From 1643 on, French slaving activities in Africa, both legal and otherwise, steadily increased, and mostly in the Senegambia region. The illegal slave trade was growing at five times the rate of the legally sanctioned trade. Therefore, in or der to empower the $\mathrm{F}$ rench $\mathrm{c}$ rown to $\mathrm{c}$ ollect $\mathrm{r}$ evenues from this a ctivity, the king's c ontroller of finance, J ean-Baptiste Colbert (1619-1683), c reated a new or ganization in 1672. B ringing together a consortium of four P arisian entrepreneurs (Maurice E grot, François François, Claude d' A pougny and François Raguenet), Colbert facilitated their founding of the French Senegal Company, the function of which was the purchasing, ownership and operations of all French facilities in northwest A frica, then mostly consisting of some fledgling forts and trading pos ts on $\mathrm{t}$ he $\mathrm{S}$ enegal $\mathrm{R}$ iver. B y controlling these stations on African s oil, F rance's position in the slave trade was strengthened and a steady supply of A frican labor to her $\mathrm{N} \mathrm{ew}$ World colonies assured. From 1675 to 1700, Martinique took 40,000 slaves, Guadeloupe 8,000, Saint-Domingue ( Haiti) s lightly ove r 7,000 a nd C ayenne (French G uiana) on t he S outh American mainland, approximately 2,000. Best of all, the French crown reaped its share of the profit on each African slave sold in these parts. And to insure the success of this new enterprise, French forces seized the island of Gorée, just south of Cape Verde, from the Dutch in 1677, as well as the Portuguese fort at Arguin in the following year.

\footnotetext{
${ }^{69}$ Palmer, Bondage Studies, 34. Palmer explains that the French Guinea Company's participation in the slave trade dipped following the Treaty of Utrecht, but when hostilities broke out between Britain and Spain from 1719-1722, French i nvolvement momentarily spiked t o p ick up the slack $1 \mathrm{eft} b$ y the B ritish Royal South $\mathrm{S}$ ea C ompany. Hostilities r ecurred be tween these t wo E uropean nations from $1727-1729$, a nd therefore the French o nce a gain revved up their role in the trade. The War of Jenkins Ear, in 1739, dealt a death blow to asiento trading.
} 
Map 3.3: Political map of the contemporary Caribbean and circum-Caribbean. Presentday Haiti was known as Saint-Domingue in the eighteenth century.

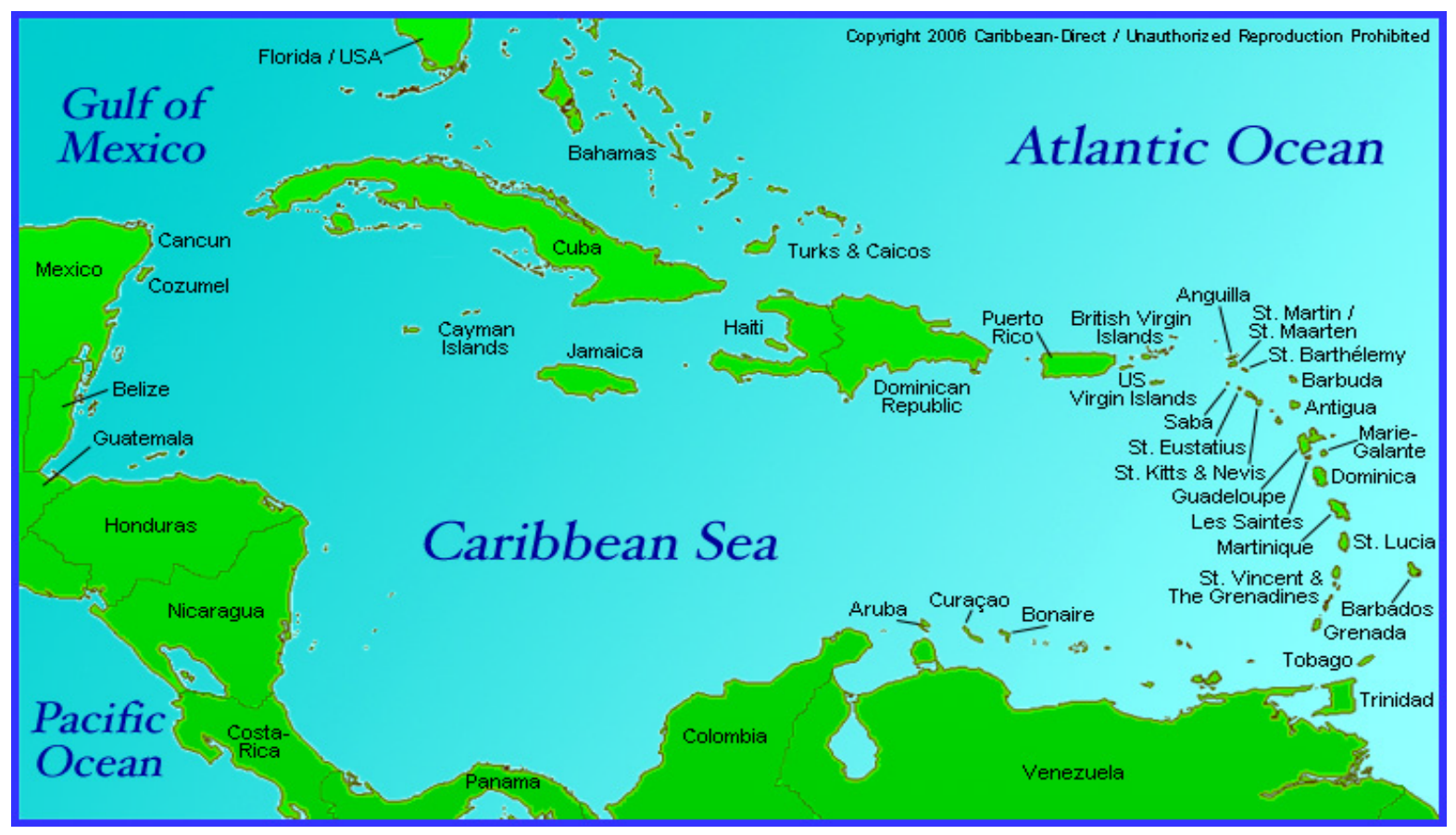

Source: http://learninglatinamerica.wikispaces.com

Because of the huge profits being raked in by the Senegal Company, it was enlarged and granted ne w r esponsibilities in 1678. It w ould he nce exercise a m onopoly ove $\mathrm{r} t$ he w hole African coast. However, much like many of the smaller French asientos that preceded it, the Senegal Company soon became top-heavy with too many officials in Paris and bogged down in squabbles over the extension of bureaucratic authority. Thus, the company declared bankruptcy. It was then reorganized twice by Colbert who, most likely because of his penchant for imposing bureaucratic structures, never was able to resuscitate it. The enterprise was continually plagued by the sinking of its ships by pirates, fresh debts resulting in unpaid crews, and the death of too many s laves i n $\mathrm{t}$ ransport t o the $\mathrm{N}$ ew $\mathrm{W}$ orld f rom A frica. Because of $\mathrm{t}$ hese problems, $\mathrm{t}$ he 
ambitious plans of Colbert for the monopoly of the A frican s lave trade by the French Senegal Company had to be laid aside. ${ }^{70}$

Convinced, however, that tremendous profits lay in wait for France by expanding further down the coast, the Senegal Company was split in two in 1684. The original company would continue its operations north of the Gambia River, but the new Compagnie de Guinée (Guinea Company), w ould c onduct a $11 \mathrm{t}$ rade s outh of that $\mathrm{r}$ iver. $\mathrm{T}$ o he ad the Guinea $\mathrm{C}$ ompany w as Colbert's s on and successor Jean-François, the Jesuit-educated Marquis of S eignelay. The son was most likely involved with his father in the company's prior reorganizations, and so he was at least $\mathrm{f}$ amiliar $\mathrm{w}$ ith its o perations. A nd as far as s elling s laves in the $\mathrm{N}$ ew $\mathrm{W}$ orld, $\mathrm{t}$ he $\mathrm{t}$ wo companies w ere supposed to cooperate. $\mathrm{N}$ evertheless, the old S enegal Company continued to perform poor ly. It failed t o a ttract i nvestors. I t a lso r elied t oo much on s ubsidies from the French c rown $\mathrm{j}$ ust to s tay in bus iness. For a ctivities nor th of the G ambia, i nvestors ba cked various private interlopers. The Senegal Company w as sold yet a gain, this time to one of its directors, Claude d'Apougny, but soon came to ruin. ${ }^{71}$

On $\mathrm{t}$ he ot her ha nd, $\mathrm{t}$ he $\mathrm{F}$ rench $\mathrm{G}$ uinea $\mathrm{C}$ ompany pr oved i tself qui te f ormidable i $\mathrm{n}$ advancing French commercial interests south of the Gambia River. The company dispatched a contingent led by Jean-Baptiste de Gennes to expel the British from Fort James on the Gambia River, and then another contingent led by André Brüe, to build a French fort at Abreda on the northern bank of the Gambia River, thus consolidating the French position in that strategic zone.

\footnotetext{
${ }^{70}$ Hugh Thomas, The Slave Trade: The Story of the Atlantic Slave Trade, 1440-1870 (New Y ork: S imon and Shuster, 1997), 192-193. The company's best years were 1682-1684, when its ships were carrying 1,520 enslaved Africans annually from the Senegal River area.

${ }^{71}$ Ibid, 193.
} 
Now the company h eld a s ure ba se of ope rations in A frica to further s pearhead its s outhern push. $^{72}$

The F rench advance do wn the A frican $\mathrm{c}$ oast $\mathrm{w}$ as of great $\mathrm{c}$ oncern $\mathrm{t} \mathrm{o}$ the $\mathrm{P}$ ortuguese authorities in both Angola and Lisbon. B y the late seventeenth century, the Portuguese found themselves in a weak position in Angola, so much so that they postponed any further attempts at inland pe netration in favor of $\mathrm{s}$ trengthening their c oastal $\mathrm{d}$ efenses, pa rticularly from Luanda north to Cabinda. It was in this area, particularly, that interloping slavers, British and Dutch as well as F rench, s ucceeded in s mashing P ortugal's m onopoly of the s lave trade. D espite the attempts of the $\mathrm{P}$ ortuguese t o fortify their pos ition in this a rea, how ever, British, D utch and French ships were pushing further south down the coast, all the way to Benguela; and in all the area in between, including Luanda, they were buying slaves from Angolan chiefs right under the nose of the Portuguese. While the Portuguese did construct a few forts and settlements in this strategic zone in the latter half of the eighteenth century, it was too little and too late. ${ }^{73}$

The success of the F rench, B ritish, and D utch in pe netrating P ortuguese W est A frican coastal dom ains as far south as Cabinda, Luanda and Benguela was based on the sale of high quality manufactured goods that were more economically produced than by the Portuguese back in Europe or those established in Africa. Africans from the interior, primarily Lunda-Imbangala, migrated t o t he c oastal a reas i $\mathrm{n}$ or der $\mathrm{t}$ o $\mathrm{t}$ rade i vory, $\mathrm{d}$ yewoods, $\mathrm{m}$ inerals, gum, and, $\mathrm{m}$ ost importantly, slave labor with these interloping Europeans. ${ }^{74}$

At $t$ his poi nt, i t i s i mportant t o pr ovide s ome c onnection w ith the French $G$ uinea Company to transactions with the Lunda-Imbangala peoples on the Angolan and Congo coast. Of c ourse, the a gents of bot $\mathrm{h}$ the British R oyal South S ea Company and the French Guinea

\footnotetext{
${ }^{72}$ Ibid., 194.

${ }^{73}$ Péllisier and Wheeler, Angola, 46, 47.

${ }^{74}$ Birmingham, "African Response," 22-23.
} 
Company were seeking productive blacks between the ages of fourteen and twenty-five years, and free of any physical di sabilities, and they w ould be pleased to accept such from wherever they c ould find them. $\mathrm{H}$ owever, $\mathrm{m}$ ost of the agents pr eferred to pur chase their s laves from private traders on the islands of the Caribbean and then to resell them to the Spaniards. It was simply more economical than dispatching ships all the way to Africa and back. Nevertheless, as was noted in the two previous chapters, the French Guinea Company purchased a goodly portion of their slave labor force from the Dutch on the islands of Curaçao and Bonaire, from the Danes on $\mathrm{S}$ aint $\mathrm{T}$ homas, $\mathrm{f}$ rom $\mathrm{t}$ he $\mathrm{E}$ nglish i $\mathrm{n}$ Jamaica or $\mathrm{B}$ arbados, or $\mathrm{f}$ rom $\mathrm{F}$ rench $\mathrm{t}$ raders i $\mathrm{n}$ Martinique. The British relied primarily on their markets in Jamaica, but also purchased slaves from $\mathrm{B}$ arbados, $\mathrm{S}$ aint $\mathrm{C}$ hristopher, $\mathrm{C}$ uraçao and $\mathrm{S}$ aint $\mathrm{E}$ ustatias. ${ }^{75}$ It is remarkable how little attention $\mathrm{w}$ as $\mathrm{p}$ aid by the a gents to the political and military conflicts that w ere taking $\mathrm{p}$ lace between their respective countries of origin back in Europe, so long as the profits kept rolling in. But while the two companies continued to obtain the majority of their slave labor force from the islands of the Caribbean, they also brought a portion directly from the African coast. P almer relates numerous instances where the French Guinea Company transported Africans from Cape Messurado, Loango and $\mathrm{C}$ abinda t o por ts in the $\mathrm{N}$ ew $\mathrm{W}$ orld, $\mathrm{s}$ uch a s Cartagena or B uenos Aires. ${ }^{76}$ While Cape Messurado was situated at the mouth of the Saint Paul River in Liberia, not far from that c ountry's contemporary capital of Monrovia, it should be kept in mind that both Loango and $\mathrm{C}$ abinda were strategic points in the Trans-Atlantic slave trade, where the French and other interlopers had contact and dealings with various elements of Imbangala society.

In A ngola, $\mathrm{m}$ oreover, $\mathrm{t}$ he ke y $\mathrm{t}$ o $\mathrm{s}$ uccessfully engaging i $\mathrm{t}$ he $\mathrm{s}$ lave $\mathrm{t}$ rade was $\mathrm{t}$ he development of $\mathrm{c}$ lose tie s to the Imbangala. Political constraints on the s lave $\mathrm{t}$ rade in $\mathrm{t}$ he

\footnotetext{
${ }_{75}^{75}$ Palmer, Bondage Studies, 32.

${ }^{76}$ Ibid., 33 .
} 
eighteenth c entury $\mathrm{C}$ aribbean $\mathrm{w}$ ere i mpelling the $\mathrm{E}$ uropeans t o $\mathrm{r}$ evitalize $\mathrm{t}$ heir ope rations i $\mathrm{n}$ Africa. $\mathrm{T}$ his $\mathrm{r}$ epresented a s ignificant $\mathrm{s}$ hift in policy for the $\mathrm{o}$ fficers of $\mathrm{t}$ he $\mathrm{F}$ rench $\mathrm{G}$ uinea Company, who previously acted upon the assumption that those slaves that were purchased from Caribbean i slands, generally s peaking, a rrived i $\mathrm{n}$ a $\mathrm{m}$ uch $\mathrm{h}$ ealthier condition $\mathrm{t}$ han $\mathrm{t}$ hose transported to the New W orld direct from A frica. M ost of those A fricans stopping over in the Caribbean at least had the oppor tunity of r ecovering from any illnesses c ontracted du ring the Atlantic passage, or even, prior to departure back in Africa. Chourio and other company traders were astute in this regard, realizing that healthy slaves would definitely fetch a higher price than those $\mathrm{p}$ hysically i ncapacitated. $\mathrm{T}$ herefore, it was al ways in the $\mathrm{b}$ est financial interest of the asiento company agent to purchase slaves direct from the $\mathrm{C}$ aribbean islands, or in the case of those coming immediately from Africa, to allow the ships transporting them to dock at an island port in or der to a llow the A frican cargo t ime to r efresh or pe rmit the slaves t o s ufficiently recover from sundry infirmities be fore proceeding on to markets in the Spanish Main. ${ }^{77}$ This continued until the War of the Spanish Succession. F or it was around this time that competing European colonial pow ers be gan $t \mathrm{o}$ e xpel foreign s laving ope rations $\mathrm{f}$ rom $\mathrm{t}$ hose $\mathrm{C}$ aribbean islands under their control, as Chourio's enterprise in Curaçao was closed by order of the Dutch. Recall that they placed Chourio under a cloud of suspicion, be lieving that he was acting as an agent of France.

Thus, with Chourio's inability to obtain the more physically-fit, A frican-derived bl acks from the Caribbean, he had to turn to Africa. And according to the records of the French Guinea

\footnotetext{
${ }^{77}$ Ibid., 30, 31. Chourio worked for the French Guinea Company's branch in Cartagena, from there he was further deployed to Maracaibo. According to the company's guidelines from Cartagena, an African in perfect health was counted as one pieza (piece). F ractional values followed for various physical disabilities, such as gray hair being $1 / 3$, each missing toe $1 / 6$, one eye $1 / 2$, ringworm covered body $1 / 4$, partially ringworm covered body $1 / 6$, too old $1 / 4$, etc. The application of such reductions often resulted in "acrimonious" disputes between the Spaniards and agents of the asientos. At least with a lower measurement there was some compensation for the company as it was not required to pay as burdensome a tax.
} 
Company, just such a s hift in the g eographic area of op erations is not ed. P almer s tates that between 1703 a nd the signing of the Treaty of Utrecht in 1713, the French Guinea Company diverted at 1 east $t$ hree, and $m$ aybe up $t$ o s ix of $i$ ts fleet of $t$ wenty-four s hips ope rating in the Caribbean to the imp ortation of s laves to $\mathrm{C}$ artagena directly f rom the Central $\mathrm{W}$ est A frican coast. ${ }^{78}$ This process could only have accelerated after that, with the ascendancy of the British as the chief slave trading power in the New World.

The British were vigilant in protecting this newly acquired monopoly. As noted in the previous chapter, Chourio's continued involvement with the French Guinea Company inspired a stream of protests by the representatives of the British company addressed to the Spanish king, his court and Spanish colonial administrators in all of those areas of Nueva Grenada (Colombia) and Venezuela where he was operating, At first, the king ordered Chourio to cease and desist, but later on changed his mind, and even commended him for the outstanding job he had done in both suppressing rebellious Native Americans and promoting the R oman Catholic faith in the Sur del Lago Maracaibo region. Why this change of mind with regard to Chourio?

There w ere two reasons for this reversal. F irst, the S panish settlers of P eríja b enefited immensely from the presence of a military contingent in their village. They felt safe and secure from a ny f uture forays that $\mathrm{m}$ ight be 1 aunched against $t$ hem $b y t$ he $\mathrm{M}$ otilones or a ny ot her Amerindian $r$ enegades. In $t$ he he arings $\mathrm{c}$ onducted a gainst $\mathrm{C}$ hourio, $\mathrm{m}$ any of $\mathrm{t}$ hese a ffected individuals came forth to voi ce their s upport of his endeavors to the S panish judges. ${ }^{79}$ And second, it was clear that the acquisition of the asiento by the French Guinea Company served as an indication of the Spanish Crown's approval of French commercial expansion in areas of the

\footnotetext{
${ }^{78}$ Palmer, Bondage Studies, 33.

${ }^{79}$ Findings of the Royal Commission at $\mathrm{M}$ aracaibo in favor of $\mathrm{J}$ uan $\mathrm{C}$ hourio de Iturbide, signed a nd sealed by Joseph Moreno de Santisteban, the public scribe and clerk of court, 5 September 1732. Archivo Histórico Nacional de Colombia (Ciudades de Venezuela), Catálogo R-6:66-84, Public Library, Mérida, Venezuela.
} 
Americas a nd $\mathrm{C}$ aribbean unde $\mathrm{r} i$ ts $\mathrm{j}$ urisdiction. T he $\mathrm{C}$ rown $\mathrm{w}$ as a pparently $\mathrm{w}$ illing $\mathrm{t} \mathrm{o} \mathrm{t}$ weak those rules of international trade that granted a British monopoly of the s lave trade when and where it suited its purposes. And if not for the special royal allowance granted Chourio to import blacks directly from A frica, the existence of a distinct A fro-Zulian community would be in doubt.

\section{Afro-Zulians}

This s ection i nvestigates s ome of 1 inkages of $t$ he A fro-Zulians $t$ o A ngola a nd ot her regions of Africa. Interestingly, the blacks of the Sur del Lago still maintain much of the music, customs, words and even religious forms of African origin. It can be determined that there were actually three waves of Africans to arrive in the Sur del Lago region. As an academic researcher of the A fro-Zulians, Martínez concludes that the first wave of Africans came as the result of a forced e xodus from A ngola, Burkina $\mathrm{F}$ aso, the $\mathrm{C}$ ongo, Zaire, and ot her $\mathrm{c}$ ountries du ring the period of 1598 through 1611 , and that these were largely concentrated in what is now the Sucre district. ${ }^{80}$ According to Palmer, it can be surmised that a second wave began with the era of the asiento, $\mathrm{w}$ here $\mathrm{t}$ he $\mathrm{m}$ ajority of $\mathrm{s}$ lave 1 abor arriving $\mathrm{t}$ hroughout $\mathrm{V}$ enezuela $\mathrm{w}$ as either 1 ater generation $\mathrm{A}$ frican from va rious i slands of the $\mathrm{C}$ aribbean or s omewhat recently a rrived from Africa but processed through factories on the islands. ${ }^{81}$ The A fricans imported to the Sur del Lago Maracaibo by Juan de Chourio constitute the spearhead of a third wave of black infusion. With $\mathrm{t}$ he $\mathrm{w}$ ar o $\mathrm{ft}$ he $\mathrm{S}$ panish $\mathrm{S}$ uccession, i nter-Caribbean an $\mathrm{d}$ circum-Caribbean $\mathrm{t}$ rade $\mathrm{w}$ as severely $\mathrm{r}$ estricted. Most of the s laves a rriving in $\mathrm{V}$ enezuela $\mathrm{w}$ ere $\mathrm{t}$ hen $\mathrm{c}$ oming di rect f rom Africa. In addition, Chourio's contingent was brought over for the express purpose of military augmentation, and not for work in the fields or mines.

\footnotetext{
${ }^{80}$ Carrillo, "En la tierra de los hijos de Ajé."

${ }^{81}$ Palmer, Bondage Studies, 33.
} 
In this region, the name of "Chourio" is also quite common, keeping in mind that Juan Chourio had ordered that his last name be branded on the bodies of all the Africans he brought there. Also, when one enters a populated area in the Sur del Lago, the music of Angolan drums [chimbángueles] can immediately be heard. This drum is made of white balsa wood and hide. It serves to keep alive a spirit of attachment to Africa among all the residents of the Sur del Lago, but more so in the somewhat isolated villages of El Batey, Bobures, Gibraltar, San Antonio and Santa $\mathrm{M}$ aría, which $\mathrm{t}$ end $\mathrm{t}$ o $\mathrm{b}$ e $\mathrm{l}$ ess cu lturally i mpacted $\mathrm{b}$ y $\mathrm{t}$ he o verall $\mathrm{V}$ enezuela mestizo population. In addition, all of the drummers come together in celebrations in honor of the patron black saint of the Sur del Lago, San Benito, which will be examined more thoroughly in the next chapter. It will also be seen how the African cultural identity of the blacks in the Sur del Lago is manifest in the daily life and routines of the people, and how it is thereby transmitted to future generations. $^{82}$

In establishing linkages between the contingent of Juan de Chourio and the Imbangala of Angola, Martínez closely examined the origins of the chimbángueles. According to Martínez, it was in San Pedro where the special drums first were seen and heard. In this locale the Africans formed an extended family centered on the brotherhood of the Father Drum, who obliged them to unite so that each man could be wrapped in the power of the community and defined as a social being. There was continuous support for what each man was, or wanted to become. This order of unification established the basis for what each man would receive, and take back to his own village. With each strike of the chimbángueles new elements would be fused in the panorama of the Venezuelan mosaic, carried over from the heart of Africa. ${ }^{83}$

\footnotetext{
${ }^{82}$ Carrillo, "En la tierra de los hijos de Ajé."

${ }^{83}$ Martínez Suárez, Como Bailar, 5.
} 
And apart from the cultural contributions of Africans to the development of Venezuelan society, there is little doubt concerning the economic impact of slavery.

One fact cannot be denied. Venezuela was built on the back of slave labor imported from Africa. And to be sure, there was a sharp division in that labor. There were slaves dedicated to the work in the homes of the masters, and these were the ones who never sullied themselves with the tasks of the field. These s laves received b etter instruction, to include a $\mathrm{n}$ i mpartation of know ledge concerning the cultural values of the European elite. B ut these were also the one s with some time on $t$ heir hands. S ome retained vivid m emories of the far-away M otherland, while others heard the stories of the elders sitting around the campfire at night. Somewhat cognizant of both the African and the European way of life, they were in a capacity to compare and contrast all that they could see and hear. R ealizing that the Europeans were never going to consider any black man to be their e qual, they $\mathrm{pl}$ aced a great va lue on $\mathrm{t}$ he $\mathrm{r}$ etention of A frican know ledge and wisdom. This was something which could be passed on to future generations, so that they would forever know and unde rstand that they $\mathrm{c}$ ame from a race of kings. This was certainly a great advantage over those who toiled from sunup to sundown on the vast plantations. These Africans and their de scendants were always being monitored by the master's henchmen. T hese are the unfortunate blacks who rarely could find some personal time. They lived short lives, but never ceased to dream of being free. It was the black in the master's hous e, the black involved in domestic work, who found the time to orient him or herself to the tasks of finding an identity. It was i mportant $\mathrm{f}$ or $\mathrm{t}$ hese $\mathrm{s}$ laves $\mathrm{t}$ o de fine $\mathrm{j}$ ust $\mathrm{w}$ hat $\mathrm{r}$ ole $\mathrm{t}$ hey w ere going $\mathrm{t} o \mathrm{pl}$ ay $\mathrm{i} \mathrm{nthe}$ establishment of the New Africa in Venezuela. ${ }^{84}$

Religion a lso pl ayed a s ignificant r ole a s a t ool for the cultural s urvival of the A froZulians i $\mathrm{nt}$ he 1 ife of colonial $\mathrm{V}$ enezuela. La $\mathrm{U}$ niversidad $\mathrm{d}$ e Zulia a nthropologist a nd ${ }^{84}$ Ibid. 
musicologist Martínez explained that the enslavers thought of all African belief systems in terms of "witchcraft." It is for this reason that the image of the black saint (Benito) was adopted by the Afro-Zulians, having been introduced to them by the Capuchin fathers brought over by Chourio to staff the mis sion at P eríja. T his e xclusive devotion to $\mathrm{S}$ an $\mathrm{B}$ enito by the $\mathrm{A}$ frican-derived peoples of the Sur del Lago Maracaibo region is one important factor that has allowed them to preserve a "rich, cultural enclave, forever apart from the rest of Zulia." 85

Religion, how ever, proved to be one of the more important of the A frican cultural links retained by the blacks of the Sur del Lago. It carried with it elements such as language, music, and traditions that helped ke ep m emories of Africa, and especially Angola, a live in the hearts and minds of the A fro-Zulians. B ecause these el ements w ere more intimately connected with religion, they are discussed at length in the next chapter. But another factor in cultural survival and the forging of an Afro-Zulian identity is found in the strategic deployment of the Africans in the region as the vanguard of Spanish settlement on Native American lands. In the next section, the military aspect of Afro-Zulian history is explored.

\section{Military Aspect of Afro-Zulian History}

Besides the cultural and societal factors previously considered, it is important to examine some of the military aspects of A fro-Zulian hi story. T he S panish A merican E mpire spanned parts of $\mathrm{N}$ orth A merica, the $\mathrm{C}$ aribbean a nd $\mathrm{m}$ ost of $\mathrm{C}$ entral a nd $\mathrm{S}$ outh America. In or der to maintain economic and political control over so vast a te rritory, a large military presence was required. As there were not a sufficient number of Spaniards to place under arms in defense of the $\mathrm{r}$ ealm, the $\mathrm{C}$ rown 1 ooked $\mathrm{t} \mathrm{o}$ ot her s ources. ${ }^{86}$ This s ection e xamines th e d eployment of

\footnotetext{
85 Ibid.

${ }^{86}$ Jane Landers, Black Society in Spanish Florida (Chicago: U niversity of Illinois Press, 1999). In the somewhat remote region of Spanish colonial Florida, and taking into account the corporate nature of Spanish society, Spain's medieval tradition of integration and a ssimilation, and the almost constant threat to S panish sovereignty, multiple
} 
Chourio's A fricans in the Sur del Lago for the dual purpose of pacifying the Native Americans and establishing prosperous Spanish colonial settlements there.

According to the official records of the City Administration of Rosario de Períja, the need to i mport $\mathrm{m}$ anpower and ot her $\mathrm{m}$ ateriel in order t $\mathrm{c} \mathrm{c}$ arry out $\mathrm{the} \mathrm{p}$ acification of $\mathrm{s}$ ome of the indigenous peoples in the area is what prompted Chourio to continue in his endeavors. ${ }^{87}$ Upon hearing sundry complaints from the owners of the estates of Santa María, Santa Isabel and Santa Inés, about the problem with local indios attacking their property, Chourio decided to initiate a counterinsurgency program on his own accord. The aforementioned estates had to be abandoned in 1707 due to a s eries of a ttacks $\mathrm{c}$ arried out by the Motilones gr oups of the Coyamos and Macoes. $\mathrm{S}$ ome $\mathrm{c}$ olonists ha $\mathrm{d}$ di ed a $\mathrm{s}$ a r esult of $\mathrm{t}$ hese hos tilities, a nd the 1 ands $\mathrm{w}$ ere $1 \mathrm{eft}$ unattended. Chourio took advantage of the situation and purchased three abandoned estates in 1717 with the purpose of soliciting permission from King Philip V to establish a small town on the land and to augment it with 100 Spanish settlers, 600 slaves, and four ships of 100 tons each containing dr y goods, w ool, s ilk, w ine, r um, g unpowder, a nd w rought i ronworks, to i nclude armament, guns, and other munitions. Chourio returned to S pain to make this happen, and the license was granted him by King Philip V on 9 May 1722. When he returned, supposedly on 27 September 1723, Chourio was greatly esteemed by the local inhabitants for having taken on such a difficult task of subduing the intransigent Motilones. ${ }^{88}$

generations of Africans le veraged artisanal, diplomatic, li nguistic and military skills into citizenship and property rights. Hence, Afro-Floridians could become homesteaders, property owners, and entrepreneurs. They would not again enjoy such legal and social protections until almost two hundred years of Anglo history had passed.

${ }^{87}$ La Alcaldia Rosario de Períja, Historia: Su fundador, http://www.alcaldiarosariodeperija.com/ve (27 A pril 2009). This is the official city of Rosario de P erija website. The information posted here was garnered from a discourse, "La Villa de Nuestra Señora del Rosario Pacificación y Fundación," (The Village of Our Lady of the Rosary: $\mathrm{P}$ acification a nd $\mathrm{F}$ oundation), de livered $\mathrm{b}$ y $\mathrm{t}$ he $\mathrm{C}$ atholic pr iest a nd $\mathrm{V}$ enezuelan hi storian from $\mathrm{t}$ he Archdiocese of Caracas, $\mathrm{M}$ arcelino $\mathrm{L}$ aurens, on $9 \mathrm{M}$ ay 2006, t o c ommemorate the $284^{\text {th }}$ anniversary of $\mathrm{t}$ he municipality's establishment. The discourse was delivered at the church in the town plaza.

${ }^{88}$ Historia del Municipio Rosario de Perijá, http://tuzulia.com (27 April 2009). 
With regard to this situation, Deglis A tilano Herrera Chourio, a direct descendant of the aforementioned 600 A fricans, stated that the oral tradition of the Afro-Zulians affirms that Juan de $\mathrm{C}$ hourio di $\mathrm{d}$ a rrive in 1723 , but $\mathrm{w}$ ith $\mathrm{t}$ hree ships, a nd $\mathrm{t}$ hat one of $\mathrm{t}$ hese, know $\mathrm{n}$ as " $L a$ Diáfana," later wrecked in Lake Maracaibo. He also stated that the other two ships were called La Fenicia and La Nueva Orleans. H errera Chourio s aid that the A fro-Zulian e lders did not know a bout a fourth s hip. ${ }^{89}$ In an y event, s ome o f what Herrera $\mathrm{C}$ hourio i mparted w as confirmed in the archives of the Mérida, Venezuela, public library, whence we discover that one of Juan de Chourio's ships did sink in the year 1725 while transporting 120,000 pesos worth of merchandise and produce back to Spain in exchange for more Spanish armament and munitions to be us ed in the on -going battle against the Motilones. ${ }^{90}$ In the cited d ocument, a witness argued that Chourio be allowed to continue with his mission of Native American pacification, but that the loss of 120,000 pesos be charged to his asiento account with no interest due. ${ }^{91}$ These documents are important because they confirm Chourio's mission to the Sur del Lago and placed the arrival of the Angolans in the region.

While some question the exact date that the town of Perijá was established, it is generally supposed that it is 27 September 1723, a little more than one year and four months after Captain Chourio received the royal order from the Spanish king to found it. That is when Chourio arrived back in Venezuela with 600 Africans, 150 of whom he took with him on an expedition to clear a highway with machetes and axes all the way down to the Palmar River, on the banks of which he erected the fir rst of $\mathrm{s}$ everal fo rts to $\mathrm{p}$ rotect $\mathrm{E}$ uropean $\mathrm{s}$ ettlers $\mathrm{f}$ rom $\mathrm{N}$ ative A merican at tacks. Seeing as how the first year was most likely devoted to fighting off indigenous tribes, the actual

\footnotetext{
${ }^{89}$ Deglis Atilano Herrera Chourio, interview by author, San Antonio, Zulia State, Venezuela, 31 May 2004.

${ }^{90}$ Findings of the Royal Commission at Maracaibo in favor of Juan Chourio de Iturbide, signed and sealed by Joseph Moreno de S antisteban, the public s cribe and c lerk of c ourt, $5 \mathrm{~S}$ eptember 1732. Archivo H istórico N acional de Colombia (Ciudades de Venezuela), Catálogo R-6:77, Public Library, Mérida, Venezuela.

${ }^{91}$ Ibid.
} 
work of constructing the first of many European settlements w as probably not underway until $1724 .{ }^{92}$

As far as the Native Americans are concerned, it is interesting to note that ev en toward the e nd of the ni neteenth $\mathrm{c}$ entury $\mathrm{v}$ arious ba nds of $\mathrm{t}$ he $\mathrm{M}$ otilones $\mathrm{c}$ ontinued $\mathrm{t} \mathrm{o}$ i mpede $\mathrm{t}$ he construction of settlements in the Sur del Lago of Zulia State. A news item datelined 12 March $1894 \mathrm{f}$ rom $\mathrm{W}$ ashington, D.C. $\mathrm{s}$ tates that the American C onsul at $\mathrm{M}$ aracaibo reported to the United $\mathrm{S}$ tates $\mathrm{D}$ epartment of $\mathrm{S}$ tate, that the "Motilones Indians, w ho a re not ed a s the $\mathrm{m}$ ost barbarous p eople on $\mathrm{t}$ he A merican c ontinent, ha ve r esumed a trocities." 93 The ar ticle further explains that the Motilones inhabit areas along the banks of the Catatumbo River and that "they have r esorted to such m easures that civilized pe rsons have been d riven from the rich di stricts recently settled." The prior inability of the Spanish Crown, who empowered Chourio, and at a later time the Republic of V enezuela, to pa cify the Motilones and open the S ur del Lago for settlement, $\mathrm{p}$ rompted the $\mathrm{c}$ onsul to d eclare th at " no a lternative $\mathrm{s}$ eems to $\mathrm{r}$ emain $\mathrm{b}$ ut for the [Venezuelan] Government to i naugurate a w ar of extermination, s howing no qua rter, w ithout regard to age or sex." As harsh as this measure may appear, the consul believed it was necessary because "these savages have proved utterly unsusceptible to civilizing influences, and it seems as though $t$ here $w$ as not hing 1 eft but to t reat them a s or dinary be asts of pr ey." A 11 of this is important be cause it s eems a s though the $\mathrm{M}$ otilones had not $\mathrm{c}$ hanged their $\mathrm{t}$ actics or staging grounds s ince C hourio's $t$ ime. A ccording t o t he c onsul's report, "t hey h ave o ccasionally disappeared in the de pths of the forest for a year or two, onl y to r eturn and de stroy the new

\footnotetext{
${ }^{92}$ Tulio Chiossone, Diccionario Toponímico de Venezuela (Caracas: Monte Avila Editores, 1992), 490. According to Chissone, the oldest church record in the chapel at Perijá dates back to 19 October 1724, when a European settler was b uried o $\mathrm{nt}$ he gr ounds $\mathrm{t}$ here. S ee a lso Historia del Municipio Rosario de Perijá, http://www.perija.com/elcorreodelasierra/html/rosariodeperija.htm (27 August 2009).

93 "Worst Indians in America: Venezuela Thinks of Exterminating the Motilones, R oot and Branch," New York Times, 13 March 1894.
} 
settlements in their absence, practicing the most horrible cruelties and leaving no vestige of the pioneer pos ts except the mutilated bodies of their victims." A pparently, the uproar over these atrocities a gainst the settlements $w$ as s o g reat, that the consul felt it $w$ as imp ortant e nough to report back to W ashington, D.C., that "the whole country is now insisting that the Government [of Venezuela] shall adopt drastic measures to address the evil." ${ }^{94}$

The Motilone, or Bari, are $\mathrm{n}$ ames as signed to this Native A merican ethnic g roup that constitutes a $\mathrm{n}$ i mportant br anch of the Chibcha family. T he $\mathrm{M}$ otilones a re $\mathrm{r}$ emnants of the Tairona culture. $\mathrm{T}$ hey a re pr esently $\mathrm{c}$ oncentrated i $\mathrm{n}$ nor theastern Colombia and $\mathrm{w}$ estern Venezuela and have resided in the Catatumbo River basin since at least the seventeenth century. The term Bari, be sides referring to an indigenous group, also signifies the Chibchan language currently spoken by an estimated three thousand people in the aforementioned region. Although both the Bari and the Yukpa_tribe are commonly known as "Motilones" and their languages are both frequently called "Motilon," the two languages a re entirely un related to e ach ot her. The term Motilon means "shaved head" in Spanish. It has been used since colonial times to refer to several different South American tribes who maintain this appearance, to include the Bari groups of the Coyamos and the Macoes that $\mathrm{C}$ hourio and others tried to subdue. ${ }^{95}$ Andres Marquez Correro, an authority on indigenous groups throughout northwestern Venezuela, asserts that the Motilones also extended their influence to the entirety of neighboring Mérida State, to include the black populated area of the Sucre Department, whose political jurisdiction has long been in dispute with Zulia State. ${ }^{96}$

\footnotetext{
${ }^{94}$ Ibid.

${ }^{95}$ Bari Language, http://www.native-languages.org/bari.htm (15 December 2009).

${ }^{96}$ Andrés Márquez Carrero, Introducción a la Emeritología: El caso especifico de las áreas indígenas del Estado Mérida (Mérida: Centro de Investigaciones Lingüísticas “Julio Cesar Salas,” La Universidad de Los Andes, 1986), 11.
} 
The history of relations between A frican derived and Native American peoples in areas of Latin America under European colonial rule is a complex one. M atthew Restall, a historian who focused on va rious aspects of this situation, has surmised that the relations of blacks and Native Americans throughout colonial times can be circumscribed within a fluctuating dialectic of "hostility" a nd "harmony." $\mathrm{T}$ his i nterchange, in t urn, can b e articulated w ithin the three arenas of community, culture and identity. ${ }^{97}$

Restall a nd the ot her c ontributors t o Beyond Black and Red provide m any ex cellent examples where identity has become more fluid. When original group boundaries break down, new communities are created. Both blacks and indigenous peoples in colonial Latin A merica cannot eas ily $b$ e cat egorized i $n t$ erms of $b$ irthplace, e thnicity, 1 egal s tatus or e ven $r$ ace $b y$ ethnographers, hi storians or s ociologists. For example, not a ll of those of A frican d escent arriving in colonial Latin America were African born or enslaved. Some were free-born from the Iberian P eninsula or, as noted in this dissertation, free-born Caribbean creoles of the second or third generation, perhaps mixed with European or indigenous over time. Even from the earliest epoch of conquest in the A mericas, $\mathrm{f}$ ree $\mathrm{bl}$ acks $\mathrm{w}$ orked s ide $\mathrm{b}$ y $\mathrm{s}$ ide with $\mathrm{t}$ he $\mathrm{S}$ panish and Portuguese conquistadores, earning reputations as highly skilled horsemen. S ome of these later became encomenderos, the owners of vast estates and all the attached Native American labor. ${ }^{98}$ Restall's book a lso provides s ome i nsight into the $\mathrm{m}$ anipulative a ctions of the E uropeans in setting the $b$ lacks a nd Native A mericans a t o dds w ith e ach o ther. This ta ctic a llowed the outnumbered Europeans to hold onto their tenuous positions of power for as long as possible. In those cas es $\mathrm{w}$ here $\mathrm{b}$ lacks act ively fought a gainst $\mathrm{N}$ ative A merican $\mathrm{p}$ opulations, $\mathrm{R}$ estall a nd

\footnotetext{
${ }^{97}$ Matthew Restall, "Black Slaves, Red Paint," introduction in Beyond Black and Red: African-Native Relations in Colonial Latin America, ed. Matthew Restall (Albuquerque: University of New Mexico Press, 2005), 4-5.

${ }^{98}$ Mieko N ishida, "Review of Beyond Black and Red, by Matthew R estall," American Historical Review 114:5 (October 2006): 1228-1229.
} 
Vinson poi nt out $\mathrm{t}$ hat they did s o onl y out of $\mathrm{t}$ heir o wn s elf $\mathrm{i}$ nterest. ${ }^{99}$ This milita ry regimentation of the A fricans in the $\mathrm{New} \mathrm{W}$ orld a ccomplished $\mathrm{m}$ ore than a reorganization of their individual psyches.

Moreover, $\mathrm{m}$ ilitary s ervice $\mathrm{f}$ or $\mathrm{bl}$ acks pr oved $\mathrm{c}$ entral i $\mathrm{n} \mathrm{t}$ he formation of their group identities. The black militiamen were aware of the privileges negotiated by other black soldiers throughout E uropean realms in the A mericas. T hey were cognizant that their m ilitary service provided them access to the legal tools necessary in the negotiations for the improvement, both specific and overall, in their own conditions. The African derived soldiers, according to Restall and Vinson, did not view their military service to a European crown as a "burden of race nor as a colonial pr ivilege," but $r$ ather a s a " medium $t$ hrough $w$ hich pr ivileges $\mathrm{c}$ ould be $\mathrm{w}$ on a nd individual group identities consolidated."100

A good example of this could be found in those lands under control of the P ortuguese Crown. B lack s oldiers w ere utilized on bot h sides of the A tlantic, principally in Angola and Brazil, throughout the seventeenth century. The Imbangala, a.k.a. Jagas, were known as fierce warriors i n C entral A ngola, a nd ha $\mathrm{d}$ a llied t hemselves f or a s eason $\mathrm{w}$ ith $\mathrm{t}$ he $\mathrm{P}$ ortuguese in fighting as their proxies in those interior a reas to the east of Luanda. They were exclusively male groups whose m embers liv ed in milita rized c amps, called ki-lombos. Interestingly, the counter-conquistador $\mathrm{m}$ aroon communities w hich 1 ater s prang u $\mathrm{p}$ i $\mathrm{n} \mathrm{B}$ razil $\mathrm{w}$ ere $\mathrm{c}$ alled quilombos, so named because of their alleged Imbangala leadership and military structure. The ki-lombos in A ngola $\mathrm{c}$ onstituted a $\mathrm{n}$ a lliance a mong young $\mathrm{w}$ arriors $\mathrm{w}$ ho $\mathrm{r}$ ejected $\mathrm{t}$ raditional kinship structures and the s upremacy of the e lders, m uch as the quilombos of $\mathrm{B}$ razil $\mathrm{r}$ ejected traditional $\mathrm{P}$ ortuguese $\mathrm{c}$ olonial s tructures and $\mathrm{t}$ he $\mathrm{s}$ upremacy of $\mathrm{t}$ he $\mathrm{P}$ ortuguese $\mathrm{C}$ rown. In

\footnotetext{
${ }^{99}$ Matthew Restall and Ben Vinson, III, "Black Soldiers, Native Soldiers," in ed. Restall, Beyond Black and Red, 46. ${ }^{100}$ Ibid.
} 
Angola, the Portuguese military adopted the tactics and organizational forms of the Imbangala, reconstituting th eir force in to $\mathrm{s}$ mall $\mathrm{c}$ ontingents, a llied in o perations $\mathrm{w}$ ith a $\mathrm{v}$ ariety of lo cal African forces, t $\mathrm{o}$ i nclude pr ivate a rmies of $\mathrm{r}$ egional a uthorities ( sobas). Imbangala ar med groups allied with the Portuguese as mercenary troops and slave regiments to form the so-called guerras pretas (black troops), with each guerra preta considered a s mall infantry force. In fact, the $\mathrm{P}$ ortuguese $\mathrm{m}$ ilitary leader, $\mathrm{H}$ enrique $\mathrm{D}$ ias, himself of the Imbangala, $\mathrm{w}$ as p roclaimed by King João IV of Portugal as "Major of All Black Troops in Angola and Brazil" on 16 November $1644 .^{101}$

In the Portuguese conquest of Brazil, Imbangala fighters were brought over from Angola precisely be cause they i nspired fear in e ven the m ost hos tile $\mathrm{N}$ ative A merican oppone nts of European settlement. Schwartz explains that, "When the Central African Imbangala, the Jagas of the $\mathrm{P}$ ortuguese $\mathrm{c}$ ampaigns of $\mathrm{t}$ he $\mathrm{s}$ eventeenth century, $\mathrm{w}$ ish $\mathrm{t}$ o $t$ errify $\mathrm{t}$ heir oppone nts a nd demonstrate $\mathrm{t}$ hat be fore $\mathrm{their} \mathrm{m}$ ight $\mathrm{t}$ he us ual conventions of be havior w ere worthless, they effectively $u$ sed can nibalism as a $w$ ay o $\mathrm{r}$ itually an $\mathrm{d} p$ sychologically overpowering $\mathrm{t}$ heir opposition." 102 Therefore, it is no wonder that Chourio would seek out the Imbangala in helping him $t \mathrm{o}$ arry out $\mathrm{t}$ he $\mathrm{f}$ ormidable $\mathrm{t}$ ask of $\mathrm{s}$ ubduing $\mathrm{t}$ he $\mathrm{M}$ otilones. Since $\mathrm{t}$ he Imbangala accomplished so much in Brazil, why could they not replicate the same results in Venezuela's Sur del Lago region? The mythos of the Imbangala super soldier was one that the kinguri and subsequent Imbangala leaders would perpetuate to their advantage, and one that Chourio would latch on to as well. ${ }^{103}$

\footnotetext{
${ }^{101}$ Mattos, "Black Troops and Hierarchies," 15-16.

102 Stuart B. Schwartz, "Brazil: Ironies of the Colonial Past," Hispanic American Historical Review 80:4 (2000): 681.

${ }^{103}$ Just how Chourio employed these Africans is more fully developed in the following chapters.
} 


\section{Conclusions}

The assertions and anthropological research of Juan de Dios Martínez Suárez, building on the cultural patrimony of the Sur del Lago blacks, were afforded an hi storical vindication. B y going ba ck t o w hat i s know $\mathrm{n}$ a bout A frica i $\mathrm{n} g$ eneral and A ngola s pecifically i $\mathrm{n}$ t he 1 ate seventeenth and early eighteenth century, similar aspects between Afro-Zulian and the Angolan Imbangala cu ltures w ere es tablished. $\mathrm{T}$ his ch apter al so d emonstrated h ow g eographic factors were responsible for the push westward by the Imbangala from their homes in the lower Congo and northeastern Angolan regions, and how this same w estward trek brought them into contact with sundry Europeans, but particularly the French at Cabinda, who und er the auspices of the French $\mathrm{G}$ uinea $\mathrm{C}$ ompany had be en moving s teadily s outh dow $\mathrm{n}$ the $\mathrm{W}$ est $\mathrm{A}$ frican c oast from Senegal for at least a century. It was also explained how some of the provisions of the Treaty of Utrecht i mpacted $\mathrm{C}$ hourio, forcing hi $\mathrm{m}$ and ot hers in the $\mathrm{F}$ rench $\mathrm{G}$ uinea $\mathrm{C}$ ompany to shift a goodly percentage of their operations from the Caribbean and back to Africa. Furthermore, this chapter delineated the needs of the Spanish Crown to suppress the insurrections of indigenous peoples throughout $\mathrm{C}$ entral a nd $\mathrm{S}$ outh A merica, a nd s howed that their recruitment of bl ack soldiers, mostly from Angola, served to accomplish this mission. T aking into account that the theories ad vocated by Martínez ar e largely anthropological, this ch apter at least succeeded in providing a basis for further historical inquiry into the origins and expansion of the Afro-Zulian community in V enezuela. T he 1 egacy of the $\mathrm{S}$ ur de 1 Lago A fricans $\mathrm{w}$ ill be explored in the remaining chapters. 


\section{CHAPTER FOUR}

\section{RELIGIOUS FACTORS}

\section{Introduction}

The view that history is primarily about the contemporary social relations of those who relate it has important repercussions for the way in which any group defines itself in relation to another. The same holds true for enslaved A fricans and Europeans. E lucidating on this point, Raymond W illiams pe nned that " much of the most a ccessible a nd i nfluential w ork of the counter-hegemony is historical; the recovery of discarded areas or the redress of selective and reductive interpretations."

In the academy of A fricana Studies, this would be referred to as the Sankofa principle. The sankofa is an Akan ideogram or Andinkra symbol from Ghana representing a long necked bird that is reaching back into its own feathers to "seek, and take, or recover." ${ }^{2}$ In the context of Africana S tudies, the Sankofa principle hi ghlights a n A frocentric m ethodological pr actice of historical $r$ ecovery; an $d w$ ith $r$ egard t o t he em ergence of $s$ yncretic $f$ orms am ong the A froZulians, a critical retrieval and reclamation of the African past is evident.

The Sankofa principle e specially applies to r eligious matters, where the hidden, denied and undi scovered truths of the A frican presence, i nitiative and e xperience in the $\mathrm{N}$ ew $\mathrm{W}$ orld contribute much to the spiritual empowerment of black people. There is perhaps no example for which this observation could be truer than the experience of the African-descended population of the Western Hemisphere. Transported to these shores under severe conditions that immediately severed th em $\mathrm{f}$ rom mo st $\mathrm{o} f$ th eir e thnic, lin guistic a nd $\mathrm{f}$ amilial tie $\mathrm{s}$, th e A fricans $\mathrm{w}$ ere systematically $d$ enied $t$ heir $h$ istories th at mo st o ther $\mathrm{p}$ eoples a ccept a $\mathrm{s}$ th eir $\mathrm{b}$ irthright.

\footnotetext{
${ }^{1}$ Raymond Williams, Marxism and Literature (Oxford: Oxford University Press, 1977), 116.

${ }^{2}$ Maulana Karenga, Introduction to Black Studies, 555.
} 
Nevertheless, $\mathrm{m}$ any of these A fricans and A frican-derived pe oples de veloped br illiant an $\mathrm{d}$ resourceful strategies of survival and adaptation, proving not only that their past is recoverable, but that it c ontains proud a nd a utonomous hi stories that bol ster the w orld pa trimony of the African D iaspora. $\mathrm{O}$ ne $\mathrm{s}$ uch $\mathrm{g}$ roup $\mathrm{t}$ hat ha $\mathrm{s}$ de monstrated $\mathrm{t}$ his is the A fro-Venezuelan community in the S ur d el Lago. For these A fro-Zulians, the dramatic vehicle providing the means to relate and affirm their history have been the performances and festivities dedicated to the syncretic melding of Ajé and San Benito.

The questions related to African religion in the Americas encompass numerous concerns: areas of influence, doctrine, dogma, epistemologies, identifiers, liturgy, persecutions, priesthood, transformations, values, etc. ${ }^{3}$ This chapter examines ways in which religious aspects of African culture allowed the Angolan blacks and their descendants to fight the process of dehumanization in the Sur del Lago and the rest of Venezuela. The religious beliefs and rituals of the Mbundu, Ndembu, Kongo and Imbangala, for example, survived in various forms throughout the African slave trade diaspora, and beyond. ${ }^{4}$ And most importantly, these beliefs and rituals provided the strongest forms of resistance a gainst the hardships of enslavement by allowing the A fricans to maintain at least a modicum of their cultural legacy and institutions.

In the context of bot $\mathrm{h}$ cultural s urvival a nd $\mathrm{p}$ reservation, bot $\mathrm{h} \mathrm{A}$ frican a nd Africanderived religious be lief systems were important for all bl ack pe ople in the $\mathrm{N}$ ew $\mathrm{W}$ orld. T he amalgamation between religions (syncretism) was one process by which blacks of Africa and the Americas (to include the Caribbean) were able to maintain and enhance some elements of their African id entity. $\mathrm{H}$ owever, in Latin A merica s laves $\mathrm{n}$ eeded to $\mathrm{b}$ e $\mathrm{b}$ aptized in to th $\mathrm{e} \mathrm{R}$ oman

\footnotetext{
${ }^{3}$ Deoscoredes M. D os S antos an d J uana E lbein D os S antos, "Religión y cultura negra," in África en América Latina, ed. Manuel Moreno Fraginals (Paris: UNESCO, 1977), 103.

${ }^{4}$ Rachel Dowty, "Review of James H. Sweet, Recreating Africa: Culture, Kinship, and Religion in the AfricanPortuguese World," Journal of World History 16:3 (September 2005): 375.
} 
Catholic $\mathrm{C}$ hurch e ither $\mathrm{b}$ efore le aving A frica o $\mathrm{r}$ imme diately $\mathrm{u}$ pon th eir a rrival in th e $\mathrm{N}$ ew World. They were also required to undergo a course of religious instruction. S o how did any African religion, or semblance of one, not only survive but prosper in the New World?

To answer these questions, the status of blacks in Africa and the New World needs to be examined in the light of Christian doctrine from the beginnings of the slave trade. From the end of the s ixteenth c entury onw ards, the i dea that a $\mathrm{C}$ hristianized A frican co uld $\mathrm{r}$ emain a s lave began to $\mathrm{g}$ ain s ome $\mathrm{c}$ urrency with E uropean leaders. T hey r easoned that the i mposition of a servile régime upon A frican peoples might actually be good for them in that while their bodies were en slaved, $t$ heir s ouls $\mathrm{w}$ ould be 1 iberated. $\mathrm{N}$ evertheless, $\mathrm{t}$ he $\mathrm{e}$ xtent of $\mathrm{t}$ his $\mathrm{r}$ eligious indoctrination in Portuguese and S panish areas of Catholic A merica w as not as intense as one might p resume. Because r eligion $\mathrm{w}$ as v iewed a s m ore s ocial than $\mathrm{m}$ ystical in these $\mathrm{C}$ atholic colonies, a recently arrived, enslaved A frican only needed to memorize a few short prayers or ritual gestures in order to be granted baptism, supposing he or she had not already been baptized at the port where the s lave ship took him or her a board, or e ven prior to th at in the A frican interior. B ecause b oth the $\mathrm{S}$ paniards and the $\mathrm{P}$ ortuguese $\mathrm{m}$ ade s ocial access easier for those acquiring a "white soul," the acceptance of Roman Catholicism by Africans was looked upon as a tool to make life for themselves and their families a little easier by opening the doors for more opportunities. It $\mathrm{w}$ as not $\mathrm{s}$ een, $\mathrm{t}$ herefore, a $\mathrm{s}$ a be trayal of $\mathrm{t}$ heir A frican be liefs. A $\mathrm{s}$ the proselytizing w as m uch less forceful, ge nerally s peaking, than in P rotestant a reas of the $\mathrm{New}$ World, i $\mathrm{t} w$ as easier $\mathrm{f}$ or A frican $\mathrm{c}$ ultural a nd religious $\mathrm{f}$ orms to e ndure in Latin A merica. Surviving beliefs in African deities, for example, fused with Catholicism and took the form of an emerging syncretism. ${ }^{5}$

\footnotetext{
${ }^{5}$ Roger Bastide, African Civilizations in the New World (New York: Harper and Row, 1971), 152-153.
} 
In $\mathrm{t}$ his $\mathrm{c}$ hapter $\mathrm{t}$ he e volution of bot $\mathrm{h}$ i nter-African an $\mathrm{d}$ New $\mathrm{W}$ orld s yncretism i s examined. A mong the Africans, a fusion of Yoruba and sundry Angolan and Congolese belief systems was already underway before the arrival of the Europeans; and in the Americas and the Caribbean an integration of A frican, European and Native American religions took place, with the process continuing up to the present time. O f particular note, the relationship between the African Ajé and the Catholic San Benito in the Sur del Lago Maracaibo is established within the parameters of spiritual syncretic phenomena in both Africa and Venezuela.

Inasmuch a s s yncretism m anifests through a ccumulation ( such a s m agic s pells, s ongs, etc.), ecologically, ethnically, institutionally, and sociologically, the limited scope of this chapter will only allow for an examination of ethnic factors (Yoruba and Bantu-speaking A fricans), as well a s in stitutional c onsiderations s uch a s inter alia phenomena, w hereby as ystem o f correspondences be tween A frican de ities is drawn and linked to a pl ane of e vents de pendent upon a co llective aw areness, or reinterpretation of the as sociated phenomena. ${ }^{6}$ In the case of drawing connections between the Imbangala of Angola and the Yoruba of Nigeria, determining the areas of influence in Africa for the orisha Ajé assumes primary importance in the bolstering of some assertions by Juan de Dios Martínez.

\section{Clash of Belief Systems}

As $t$ he $\mathrm{E}$ uropeans e xperienced pr oblems i $\mathrm{n} t$ he i nterpretation of $\mathrm{t}$ he $\mathrm{m}$ eaning and significance of A frican r eligious practices b ased on d eep-rooted and pe rvasive cultural biases, they a ttempted $\mathrm{t}$ o s quash $\mathrm{t}$ hese s ame i $\mathrm{n} t$ he name of s tomping out "paganism" or $\mathrm{r}$ itual "witchcraft." It is unfortunate that the Europeans used such pejorative terms to describe African religious b elief s ystems, for th ey imp licitly r educed the A frican s piritual e xpressions to their

\footnotetext{
${ }^{6}$ Ibid., 153, 154.
} 
potential for evil. Therefore, any positive aspects of A frican religious belief systems remained hidden behind a cloak of "evil." In attempts to view this situation with a semblance of balance, a contemporary historian could recognize the African's ability to control evil as just one aspect of a mo re in tricate as semblage of religious p ower. $T$ he ex istence of $\mathrm{s}$ upernatural forces $\mathrm{w}$ as a given. $\mathrm{T}$ hese $\mathrm{f}$ orces were $\mathrm{s}$ een as $\mathrm{n}$ eutral $\mathrm{i} \mathrm{n}$ ch aracter. $\mathrm{H}$ owever, a $\mathrm{C}$ entral $\mathrm{A}$ frican understanding of religious malevolence was directly linked to temporal bad luck, especially any misfortune $\mathrm{c}$ aused b y hidden hum an pow ers. T hose A fricans endowed with r eligious pow ers could do both good and evil at the same time, but it was the seventeenth and eighteenth century westerner's in ability to see th is th at $\mathrm{k}$ ept $\mathrm{h}$ im from imparting a ny $\mathrm{v}$ alue to the A frican b elief systems. $^{7}$

Because of t his limited E uropean $\mathrm{v}$ iew, the p owers of A frican r eligious l eaders w ere somewhat s tifled onc e t hey w ere $t$ raded i nto s lavery a nd removed $f$ rom $t$ heir a ncestral homelands. The Europeans attempted to force new cultural and religious roles upon the enslaved Africans. Nevertheless, these w ere not s imply adopted w ithout que stion or $r$ esistance b y the Africans. A s R achel Dowty poi nts out, $t$ he understandings of $t$ he Africans "were always mediated by ways of knowing and living that were familiar to them." 8

If o ne at tempts to analyze the religious practices of an $y$ element of the A frican s lave diaspora based on the process of creolization, then colonialist misunderstandings are perpetuated because the cultural and ethnic norms associated with these observances cannot be assessed with regard to the viewpoint of the enslaved Africans. In other words, historical viewpoints are not the sole propriety of those who maintain the historical records. W hile the enslaved were rarely the authors of most historical records, they nevertheless ex erted a v oice that carried over in the

\footnotetext{
${ }^{7}$ James H. Sweet, Recreating Africa: Culture, Kinship and Religion in the African-Portuguese World, 1441-1770 (Chapel Hill: University of North Carolina Press, 2003), 162.

${ }^{8}$ Dowty, "Review of James H. Sweet," 375.
} 
oral traditions passed on in their respective communities, as well as in the records maintained by their c olonial ma sters. ${ }^{9} \quad$ In the cas e of the 1 atter, an a ffective cu ltural filter w ould s urely b e required.

Those Africans enslaved by the Europeans found ways to demonstrate the power of their traditional religious ritual practices and belief systems as a matter of resistance to their forced "conversions" to Christianity. T hose e nslaved who w ere taught traditional A frican be liefs as children most likely retained them as adults, regardless of the numerous attempts made by their European masters to change their religious affiliations. Therefore, we see case after case in the Caribbean an $\mathrm{d}$ Latin America $\mathrm{w}$ here $\mathrm{t}$ he en slaved $\mathrm{m}$ ay $\mathrm{h}$ ave $\mathrm{cl}$ aimed $\mathrm{w}$ hatever $\mathrm{r}$ eligious affiliation their masters imposed, but this was merely a ruse to avoid unpl easant repercussions. In many instances, those A fricans left to their own de vices, such as freed slaves and maroons, returned to the religious affiliations of their childhoods. ${ }^{10}$

The Brazilian maroons in the quilombos of Palmares and surrounding areas, for example, drew much from the traditional African beliefs and practices of the Kongo, Imbangala, and other West A frican peoples. ${ }^{11} \quad$ According to the traditional religion of the Kongo, which w as a lso adopted by some of the northern bands of the Imbangala, the creator of the universe is known as Nzambe. $\mathrm{H}$ e d wells ab ove an $\mathrm{d} p$ resides o ver a w orld of ancestor s pirits. ${ }^{12}$ Many A fricans believe that when a family m ember di es a nor mal de ath, he or she joins this s pirit w orld ( or village) of the ancestors. It is these spirits who look after the living and protect the descendants to whom they have bequeathed their lands. Those spirits of those who die violent and untimely

\footnotetext{
${ }^{9}$ Sweet, Recreating Africa, 115-117, 227-230. Sweet provides a critique of the Creolization process.

${ }^{10}$ Ibid., 230.

${ }^{11}$ Dowty, "Review of James H. Sweet," 375-376.

${ }^{12}$ Carter G. Woodson, “Notes on the Bakongo," Journal of Negro History 30:4 (1945): 423, 430. The Kongo lands and peoples were repeatedly invaded and subsequently occupied by the Jagas from 1565 through the end of the seventeenth century, whence many elements of their religion were assimilated by this Imbangala group.
} 
deaths, however, are believed to be without rest until their deaths have been avenged. A spiritual medium, know $\mathrm{n}$ a mong the $\mathrm{K}$ ongo and Imbangala a s a n nganga ngombo, was employed to discover through the use of fetishes or charms called nkisi, who was responsible for the death. In their theology, there is no such thing as an accident or coincidence. A lso, healing practices and traditional religion go hand in hand, as the nganga may be consulted for herbal treatments or to root out kindoki (witches practicing b lack magic, who are thought to cause illn ess through illwill, and to eat the souls of their victims by night). ${ }^{13}$

Our understanding of these rituals has been enhanced thanks to the evangelizing outreach of the Capuchin fathers, who kept some records concerning the religious practices of Imbangala spirit me diums, or xinguilas, h ighlighting th eir imp ortance to th e community. ${ }^{14}$ The I talian Capuchin priest, Antônio Cavazzi (1621-1678), detailed the possession ritual of an Imbangala in the following paragraph:

The man or woman stands in the middle of the multitude and orders that all obey him, since the function is promoted not by caprice, but by the interior impulse of the consulted spirit. Meanwhile, the musicians play their instruments and excite those present with appropriate songs and shouting, capable of frightening even the wild be asts. $T$ hey $s$ ing $s$ ome di abolical $s$ ongs $w$ ith i nvocations, $j$ udged efficacious for pe rsuading the D evil to enter into the bod y of the person. T he person, for his or her part, swears an oath to the D evil and invites him to take possession of hi $s$ or he $r$. A $t$ the $s$ ound of these $s$ upplicants, $t$ he $D$ evil $g$ ives himself to the intervention... T hen the feiticeiro (witch) gets up with $\mathrm{m}$ uch seriousness, a nd $\mathrm{r}$ emaining $\mathrm{s}$ till $\mathrm{f}$ or $\mathrm{s}$ everal mo ments, imme diately begins to agitate, moving his eyes in their sockets, laying himself on the ground, contorting furiously, be nding a ll of hi s m embers.... The feiticeiro then be gins proffering extravagant $\mathrm{w}$ ords, $\mathrm{c}$ onfused a nd $\mathrm{m}$ etaphoric, not $\mathrm{w}$ ithout pr eviously ha ving forewarned those present that they a re not hi s words, but of the s pirit of $s$ uch deceased Jaga, whose name he then assumes, conserving [that name] until the end of the function.... The Jagas go to this possessed person because they judge that he knows everything that happens in the other life, and they use the forms of respect and $r$ everence $t$ hat $t$ hey would us e $w$ ith a $d$ emigod, i nterrogating $h$ im a nd receiving an swers as if he $\mathrm{w}$ ere the consulted s pirit. $\mathrm{T}$ he pos sessed threatens

\footnotetext{
${ }^{13}$ Sweet, Recreating Africa, 142.

${ }^{14}$ Ibid., 140-141.
} 
misfortune, predicts misadventure, curses, reprimands the avarice of the relatives, requests new sustenance, new foods, new human blood and new victims. ${ }^{15}$

\section{Figure 4.1: The Italian Capuchin priest, Antônio Cavazzi, depicted an Imbangala spirit possession ritual in this water color.}

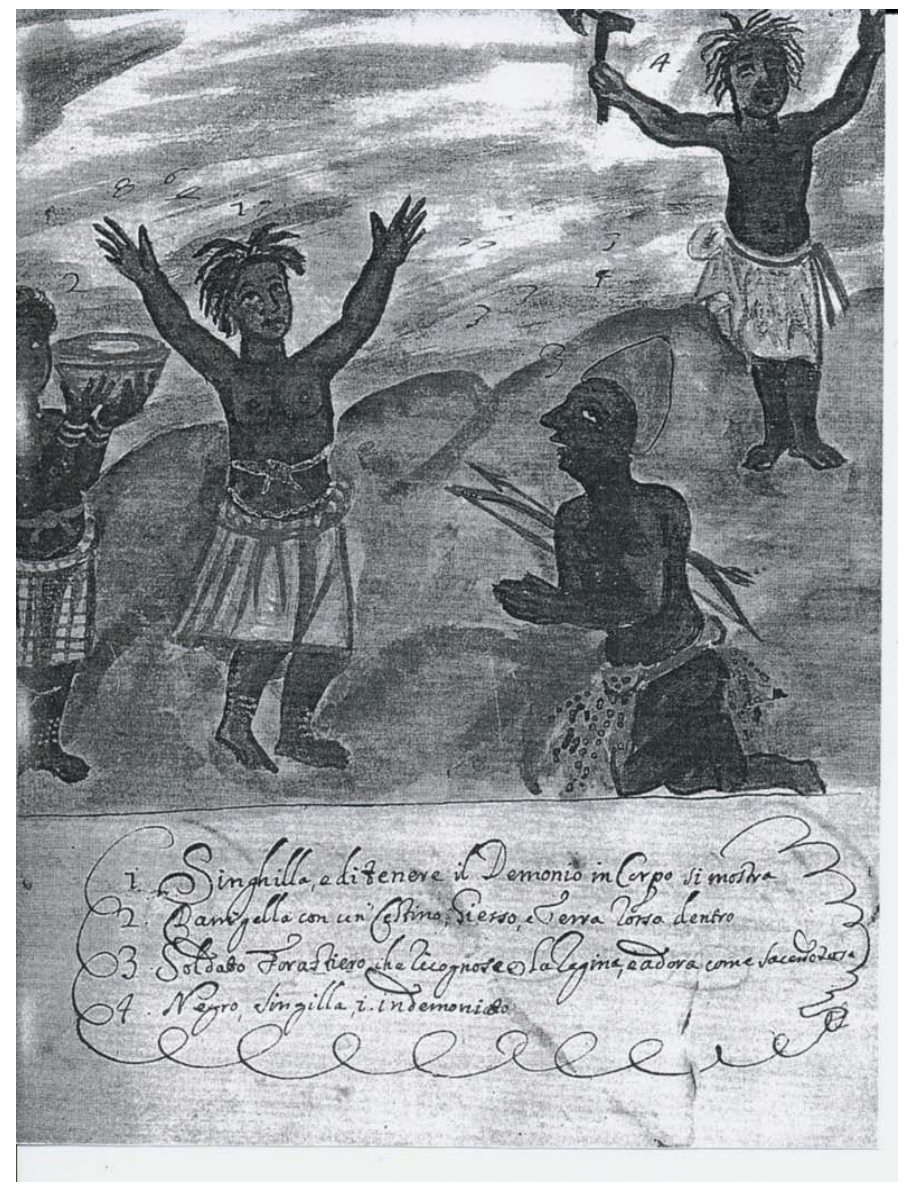

Source: James H. Sweet's Recreating Africa, page 141.

Father $\mathrm{C}$ avazzi illu strated $\mathrm{h}$ is ma nuscript $\mathrm{w}$ ith $\mathrm{w}$ atercolors $\mathrm{d}$ epicting $\mathrm{r}$ eligious $\mathrm{r}$ ituals carried out in both the Congo and Angola. In the above reproduced water color, s eventeenth century Imbangala xinguilas are depicted as being possessed by the spirits of deceased ones. ${ }^{16}$ In

\footnotetext{
${ }^{15}$ Giovanni A ntonio C avazzi da M ontecucculo, Istorica Descrizione de' tre regni Congo, Matamba ed Angola, 1665-1668, 2 vols., ed. and trans. Padre Graciano Maria de Leguzano (Lisbon: Junta de Investigações do Ultramar, 1965), 1:204-205. Original ed. published in Bologna, Italy, in 1687, followed with a 2nd ed., 1690.

${ }^{16}$ Sweet, Recreating Africa, 141. This Cavazzi reproduction courtesy of Manoscritti Araldi, Papers of the Araldi Family, Modena, Italy.
} 
the original water color, it should be noted that both spirit mediums had red taffetas tied around their ar ms, w aists an $\mathrm{d} \mathrm{l}$ egs and $\mathrm{w}$ ere $\mathrm{m}$ arked with $\mathrm{w}$ hite cl ay. A lso note the ax e-wielding xinguila in the background. Immediately upon being possessed, this spirit medium grabbed the nearest a xe a nd b egan swinging i t a round $\mathrm{i} n$ all di rections. This a xe s erved as a vi sual representation that identifies the warrior spirit who entered the body of the xinguila. T he man kneeling in the water color is a soldier client, beseeching counsel from the spirit mediums before going off to war.

It becomes apparent, therefore, that religion was also an important factor in the military life of the Imbangala. $M$ any of the religious practices of the Imbangala w ere centered on the preparation for war or war itself. But the Imbangala and other Central Africans also employed a variety of charms, talismans and rituals to protect themselves from sundry illnesses and ward off other mis fortunes in their daily lives. C avazzi al so discussed some of the strange dietary laws among the Imbangala a nd ot her A ngolan a nd Central A frican pe oples, $w$ ith c ertain $\mathrm{f}$ oods believed to empower and protect them in many ways. ${ }^{17}$ However, as we noted in the previous chapter, the Jagas, on occasion, effectively utilized cannibalism as a military stratagem to terrify their oppone nts. T hey o penly employed c annibalism as a way of ritually and ps ychologically overpowering their opposition. ${ }^{18}$ This practice was quite effective, as most Africans associated it with witches who both symbolically and a ctually "ate" their victims, thereby draining th em of wealth, luck and power. All the while, the Jagas and other Imbangala engaging in this practice were never to reveal any signs of di sgust. They also lived parasitically, pa ssing through the countryside and consuming everything in their $\mathrm{p}$ ath. T hey $\mathrm{cut}$ dow $\mathrm{n}$ the crops that others had planted, including palm trees. Rather than merely tapping the trees, the Imbangala employed an

\footnotetext{
${ }^{17}$ Ibid., 176.

${ }^{18}$ Schwartz, "Brazil," 686.
} 
ecologically s hort-sighted but e ffective pol icy of $\mathrm{c}$ utting a nd dr aining them. T he r eligious implication exists here for a spiritual transition of power from the conquered lands and peoples to the Imbanbgala. And over time, they abandoned various adopted cults of territorial deities in favor of a strict propitiation of their own ancestors. These were the on es who set the stage for the Imbangala's militarized and s eeming ruthless existence. ${ }^{19}$ Therefore, purely based on the observations of harsh practices carried out by the Imbangala, it is not difficult to understand how the $\mathrm{P}$ ortuguese a nd ot her $\mathrm{E}$ uropeans $\mathrm{c}$ ame $\mathrm{t}$ o $\mathrm{f}$ ear a nd grudgingly respect $\mathrm{t}$ hem, a s di $\mathrm{d}$ their African neighbors.

\section{African and New World Syncretism}

Although the P ortuguese va liantly tried to Christianize various Congolese and Angolan peoples from as early as 1485 , the A fricans either r esisted entirely or simply incorporated the Christian i conography i nto their ow n pa ntheon, a s they ha d don e w ith ot her orishas from neighboring $\mathrm{W}$ est $\mathrm{A}$ frican ki ngdoms i $\mathrm{n} \mathrm{t}$ he Niger-Benue region, $\mathrm{b}$ eyond $\mathrm{t}$ heir no rthern frontiers. ${ }^{20}$ This process e ven c arried ove $\mathrm{r}$ to Brazil. For example, whenever A ngolan or Congolese candomblés (syncretic belief structures) were created, their own rituals were grafted on to those of the Yoruba or Fon peoples. And all of this served to establish a double series of correspondences between their own spirits and the Yoruba orishas on one hand, and the Roman Catholic saints on the other. ${ }^{21}$ In the New World, Bastide explained that Angolan and Congolese spirits were still preserved through a direct correspondence with Yoruba deities, "just as though there were some standard dictionary that sanctioned a reciprocal transfer between one religion

\footnotetext{
${ }^{19}$ John K. Thornton, "Religious a nd C eremonial Life in the K ongo a nd Mbundu A reas, 1500-1700," in Central Africans and Cultural Transformations in the American Diaspora, ed. Linda M. Heywood (Cambridge: Cambridge University Press, 2002), 82, 83.

${ }^{20}$ Sweet, Recreating Africa, 114.

${ }^{21}$ Bastide, African Civilizations, 106, 107.
} 
and a nother." 22 But the West C entral A frican d eities w ere n ot c ompletely sublimated in the Americas a nd the $\mathrm{C}$ aribbean, for A ngolan and Congolese influences do a ssert themselves in some of the music and ritual of various candomblés and other syncretism. ${ }^{23}$

In examples taken from throughout the Americas and the Caribbean, a repositioning of archaeology and a nthropology in t erms of "ethnogenic bricolage" has s hed new light on t his process. ${ }^{24}$ Scholars of the African Diaspora can now move away from the dated generalizations of "C reolization" an $\mathrm{d} t$ oward this n ewer concept that $\mathrm{r}$ ecognizes the $\mathrm{k}$ ey interaction $\mathrm{b}$ etween agency and structure. By s hifting the focus of A frican di aspora s tudies be yond d ebates ove $\mathrm{r}$ cultural retentions and c ontinuities to a e mphasis on $\mathrm{m}$ ulti-linear cultural de velopments, new theoretical and i nterpretative f rameworks can $b$ e es tablished an $d$ ap plied t o t he an alysis of archaeological and historical data. Such investigations of African diasporas within the process of ethnogenesis $\mathrm{m}$ ake pow erful contributions t o i nterdisciplinary s tudies o $\mathrm{f}$ e thnicity, $\mathrm{r}$ ace and cultural dynamics in the numerous histories of the Western Hemisphere. ${ }^{25}$

New W orld religious ex periences ex hibit cultural influences from a vast array of W est, West Central African, European and indigenous peoples. Kevin M. Bartoy, an A fricana studies professor and archaeologist from The Hermitage in Nashville, Tennessee, directs the researcher towards Christopher C. Fennell, the a nthropologist responsible for r eemphasizing the place of archaeology within anthropology, and making a strong argument for an analysis that crosscuts artificial d isciplinary b oundaries to mo re holistically s tudy the African Diaspora th rough the

\footnotetext{
${ }^{22}$ Ibid., 109.

${ }^{23}$ Ibid.

${ }^{24}$ Christopher C.F ennell, Crossroads and Cosmologies: Diasporas and Ethnogenesis in the New World (Gainesville: University Press of Florida, 2007), 8.

${ }^{25}$ Ibid., 7.
} 
medium of e thnogenesis. ${ }^{26}$ Fennell's w ork is i mportant be cause he employs a nthropological theories c oncerning m odes of $\mathrm{s}$ ymbolic e xpression, $\mathrm{t}$ he formation a nd $\mathrm{m}$ aintenance of $\mathrm{s}$ ocial group i dentities, and the roles of individual c reativity and innovation in the context of group dynamics. Core symbols within particular groups impacted by diasporic movements across the Atlantic are keys to Fennell's w ork. These core s ymbols r eflect the fundamental as pects of a group's c osmology and s ense of i dentity w ithin the w orld. T hese s ymbols $\mathrm{c}$ an be conveyed through spoken words and ritual performances and are often depicted in tangible, graphic forms (emblematic communications). ${ }^{27}$

In many parts of Latin America and the Caribbean, highly e mbellished symbolism has developed out of the blending of diverse A frican cosmologies. S ome anthropologists refer to this $d$ evelopment as a $g$ eneral $p$ rocess o $f$ cultural ad mixture, $w$ hile o thers $u$ se $t$ he $t$ erm "creoloization" to i ndicate this cultural bl ending. E vidence of di verse a ntecedent cultures are manifest and the patterns and contours of new cultures can be defined. Where a problem exists is in making those determinations of what happened in the interim period. Ethnogenic bricolage can fill th is gap nicely, as it e ntails a creative process whereby in dividuals raised in different cultures i nteract i $\mathrm{n} n$ ew settings. $\mathrm{T}$ hese pe rsons a re of ten $\mathrm{f}$ ound $\mathrm{t} \mathrm{o}$ be a $\mathrm{t} t$ he ge ographic crossroads of $\mathrm{m}$ ultiple di asporas $\mathrm{w}$ here $\mathrm{i}$ ndividuals $\mathrm{t}$ end $\mathrm{t}$ o $\mathrm{c}$ ease di splaying e mblematic expressions of the core symbols of the former cultural groups from which they were abducted or compelled t o de part. Nevertheless, i nstrumental e xpressions of those s ame core s ymbols continue in force and are employed in private, individual spaces as part of prayers for healing or self-protection. Instrumental e xpressions of the s ame $\mathrm{c}$ ore s ymbols a re a bbreviated in $\mathrm{t}$ heir

\footnotetext{
${ }^{26}$ Kevin B artoy, "R eview of Crossroads and Cosmologies: Diasporas and Ethnogenesis in the New World, by Christopher C. Fennell" (Gainesville: University of Florida Press, 2007) in African Diaspora Archaeology Network Newsletter (December 2008): on-line only, http://www.diaspora.uiuc.edu/news1208/news1208-33.pdf, 1-5.

${ }^{27}$ Fennell, Crossroads, 8, 9.
} 
composition. A n example might be a Catholic making a sign of the cross. These instrumental expressions t ake on a $\mathrm{p}$ rosaic ap pearance that $\mathrm{c}$ an eas ily $\mathrm{b}$ e $\mathrm{r}$ ecognized $\mathrm{b}$ y m embers of o ther cultures. $\mathrm{T}$ he va ried i nstrumental s ymbols, ne w c ore s ymbols and e mblematic de signs are configured in such a way as to convey the new culture's sense of identity, and Fennell utilizes this process of ethnogenic bricolage to e mphasize the creative combination of diverse cultural elements into new configurations for the dual purpose of perseverance and self-determination. ${ }^{28}$ In exploring ethnogenic bricolage in the New World, the Kongo in West Central Africa provides an excellent case study for Fennell and others. First, a plentitude of information about the $\mathrm{K}$ ongo people, $\mathrm{t}$ heir $\mathrm{c}$ ulture, a nd $\mathrm{r}$ eligion, $\mathrm{c}$ an be $\mathrm{g}$ arnered $\mathrm{f}$ rom $\mathrm{t}$ he a ccounts of $\mathrm{t}$ he Portuguese dating back to their arrival in the region in the $1480 \mathrm{~s}$. And the second consideration would be that unl ike other A frican cultures further to the nor th, the K ongo peoples remained largely free of Islamic proselytizing e fforts. A nd be cause the $\mathrm{K}$ ongo $\mathrm{c}$ ulture e ndures to the present, a s ignificant a mount of e thnographic a ccounts ha ve be en a massed, a 111 ending a tremendous bod $\mathrm{y}$ of $\mathrm{d}$ etailed, $\mathrm{c}$ redible know ledge $\mathrm{c}$ oncerning $\mathrm{t}$ heir economic, $\mathrm{p}$ olitical a nd religious traditions. ${ }^{29}$

The Kongo kingdom also covered a vast expanse of territory, exercising effective control over much of the west central region of Africa from at least the fourteenth century onward. That kingdom included lands that are now incorporated into portions of the Democratic Republic of the Congo, Gabon, the Republic of the Congo and Angola. W hile the Kongo were the first in their $\mathrm{r}$ egion $\mathrm{t} \mathrm{o}$ a dopt $\mathrm{C}$ hristianity, $\mathrm{t}$ hey $\mathrm{m}$ ost $\mathrm{l}$ ikely di $\mathrm{d} \mathrm{s} o \mathrm{w}$ ith $\mathrm{t}$ he pr agmatic pur pose of enhancing their political power and placating the Portuguese.

\footnotetext{
${ }^{28}$ Ibid., 7-9.

${ }^{29}$ Ibid., 51, 53.
} 
With the increased intervention of the Portuguese and other Europeans in W est Central Africa, the Kongo kingdom began to fragment with the continued loss of territory. The kingship structure was replaced by a system of local chiefdoms, with each one negotiating separately with a European power. And what was left of any political cohesiveness surely came to an abrupt end with $t$ he e xpansion of $t$ he $t$ rans-Atlantic s lave tr ade and th e d ecimation of $t$ heir $s$ ubject population a s a di rect $r$ esult of this ne farious b usiness. But de spite a ll of these factors, the Kongo pe ople evidenced not only a survival of their material culture, but also of their Kongo language an $\mathrm{d} t$ he central $\mathrm{f}$ acets of $\mathrm{t}$ heir $\mathrm{r}$ eligion and s piritual out look. The de gree to w hich artifacts di rectly r elated to Kongo religion and culture ha ve be en di scovered and c ataloged in West Central Africa and other parts of the world lends credence to Fennell's investigations. He also explores expressions of Kongo cultural heritage through the transformation of their religious beliefs and practices over time in different locations. Fennell demonstrates that the Yoruba and Fon diasporas and New World symbolism intersected with the belief systems of the Kongo and other $\mathrm{W}$ est Central A frican ethnicities in te rms of private ritual observances, carvings, pottery markings, ironworks, symbolic expressions affixed to homes, and the perseverance of magic. ${ }^{30}$

In the New World, a strong trend towards ritual magic is exhibited in the Afro-Brazilian syncretism of Q uimbanda. Inasmuch a s $\mathrm{m}$ any thousands of $\mathrm{K}$ ongo a nd Imbangala w ere transported across the Atlantic to the Americas, and especially to Brazil, the rise of Quimbanda religion $\mathrm{c}$ an $\mathrm{p}$ roperly $\mathrm{b} \mathrm{e} \mathrm{v}$ iewed as a $\mathrm{m}$ anifestation o $\mathrm{f} \mathrm{W}$ est $\mathrm{C}$ entral A frican $\mathrm{r}$ eligion an $\mathrm{d}$ spirituality. A s in Africa, it is practiced in the course of sessions reserved for w orks aimed at doing or undoing evil. It is characterized by the sacrifice of animals, namely edible ones such as kids, chickens and pigeons. These are the offerings that can be used to invoke the spirits in the

\footnotetext{
${ }^{30}$ Ibid., 24, 53, 54, 62, 65-70, 78.
} 
liturgies; and these spirits, in turn, act as sacramental emissaries. ${ }^{31}$ While Benedictine and Jesuit priests in B razil perceived these $r$ ituals a s $v$ arious t ypes of id olatry and w itchcraft, the A froLatino $\mathrm{h}$ istorian $\mathrm{J}$ ames $\mathrm{S}$ weet $\mathrm{s}$ aw $\mathrm{t}$ hem as $\mathrm{r}$ epresenting "d esperate attempts $\mathrm{t}$ or esist $\mathrm{t}$ he hardships of slavery." ${ }^{32}$ In the next section, the mythology and rituals pertaining to the deity known a s A jé i n s undry parts of A frica and L atin A merica is e xamined, w ith a particular emphasis on Venezuela's Sur del Lago and how keeping a remembrance of Ajé alive helped the Afro-Zulians establish and perpetuate a New Africa on the shores of Lake Maracaibo.

\section{Ajé}

The Kongo and Imbangala peoples transported to Brazil had much in common with the Afro-Zulians of the Sur del Lago, including a devotion to the A frican deity Ajé and the Black Saint S an Benito. ${ }^{33}$ Martínez c laims that in the Sur del Lago, one of the domestic slaves was knowledgeable in the rituals and ways of Ajé. ${ }^{34}$ He brought this important knowledge over to the New World from his village in Africa, from whence he had been taken against his will. This slave be gan to pay homage to Ajé, the A frican de ity of his natal village; and soon other A froZulians began to join with him.

In c onversations that took $\mathrm{pl}$ ace on $\mathrm{t}$ he $\mathrm{g}$ rounds of the $\mathrm{g}$ randmother of M artínez, one afternoon s ome of the e lderly w ere talking a bout this dom estic s lave, a one-armed man th at caused quite a stir in old San Pedro. The grandmother related that:

One morning they got the new slave from the big ranchón (hut). T hey tied him down with ropes to try and tame him. They wanted him to work with those slaves

\footnotetext{
${ }^{31}$ Carlos Luconi, Magia Brasiliana, http://www.carlos-luconi.com/in/Conde_Luconi_Brazilian_Magic.htm, (13 March 2010).

${ }^{32}$ Sweet, Recreating Africa, 187.

${ }_{34}^{33}$ Mattos, "Black Troops," 15-16.

${ }^{34}$ Martínez, Como Bailar, 5.

${ }^{35}$ Juan de Dios Martínez Suárez, Antecedentes y orígenes del Chimbángueles (Maracaibo: La Universidad de Zulia, 1983), 79 .
} 
already $\mathrm{t}$ rained in $\mathrm{d}$ ifferent $\mathrm{p}$ lantation $\mathrm{t}$ asks. A lready $\mathrm{t}$ hey $\mathrm{h}$ ad taught him $\mathrm{t} \mathrm{o}$ harvest sugar cane in its due season. He began to work with the machete cutting with good, accurate strokes the stalks of cane. In one of many swings, however, he didn't cut the center of the cane and the machete went to separate part of his arm from the rest of his bod y! T hey s uccored him and be gan to a pply know $n$ remedies, but they did not succeed in stopping the bleeding that ran from his veins like a river th at flowed down from the mountain to in ebriate with its nectar the heart of $\mathrm{t}$ he 1 ake. $\mathrm{T}$ hey carried hi $\mathrm{m} t \mathrm{t} t$ he abode of $\mathrm{t}$ he vi llage curandero (witchdoctor), José Ignacio, a slave in one of the plantations on the out skirts of San Pedro, who as a last resort applied a paño (wet cloth), made from the web of a s pider, and the bl eeding stopped. Later, he prepared him a dose of espadilla (ground swordfish), leaves of carubombo, cañafistola and other herbs. It saved him. In view of his advanced age, and having only one arm, the masters let him help in the house with the chores to be done there. And thus, with time, they called him 'el mocho' (the "S tub") of S an P edro. W ith patience, he started the cult of Ajé, a god of his African land. His cult is called to order with the drum, accompanied by a dance and of ferings of fruit to the god. Little by little more followers and drummers were incorporated. ${ }^{35}$

The mystique that developed around Ajé in the Sur del Lago, proved ov erpowering for most A fro-Zulians. A s this cult began to incorporate more and more followers, it appears that the corpus of knowledge concerning Ajé began to expand as well, and this local man referenced by $\mathrm{M}$ artínez $\mathrm{s}$ oon $\mathrm{w}$ as accorded $\mathrm{t}$ he $\mathrm{t}$ itle $\mathrm{o} \mathrm{f} \mathrm{h}$ igh $\mathrm{p}$ riest $\mathrm{b}$ y an ac clamation $\mathrm{o} f \mathrm{t}$ he $\mathrm{p}$ eople. According to the Afro-Zulian chronicler, this intermediary between Ajé and the masses was born in the Angolan kingdom of Imbangala and he was about 30 years old when he arrived in the New World. T he Zulian professor co rrectly b elieves that the Imbangala had reached the n orthwest coast of Angola, whence they carried their devotion to Ajé with them to the New World. ${ }^{36}$

In Como bailar...., for example, Martínez r elates a $\mathrm{n}$ o ral $\mathrm{h}$ istory given to $\mathrm{h}$ im b y a $\mathrm{n}$ elderly resident of the Sur del Lago region regarding the high priest of Imbangala at old S an Pedro:

One of the first strikes of the Chimbángueles that ex isted was called Imbangala, pronounced 'Aibangala' as one would blow the $i$ in order that it would not have a forceful sound. The ancient one who started the cult of Ajé in San Pedro, as he

\footnotetext{
${ }^{36}$ Martínez, Como Bailar, 5.
} 
had the 1 iberty to vi sit of ten $\mathrm{pl}$ antations m aking 'mandaos' (deliveries) to the masters, little by little he was uniting with various slaves who were also born in the Imbangala Kingdom. B ecause of this, and the playing of their drums when they got together, the pe ople be gan to call them 'aimbangaleros,' and with the passing o f time th ey were ju st c alled Chimbangaleros, an $\mathrm{d}$ at ev ery fiesta, Chimbángueles. ${ }^{37}$

In the above-cited narration are the elements of linguistics, musicology and or al history that serve to reestablish cultural and religious connections between the Imbangala of Angola and other African nations with the blacks of the Sur del Lago. The resurrection of these elements by Martínez he lps e xplain $t$ he or igins of $t$ he $\mathrm{c}$ ult $\mathrm{i} n$ honor of $\mathrm{A}$ jé a nd $\mathrm{t}$ he $\mathrm{g}$ enesis of $\mathrm{t}$ he Chimbángueles.

But who was Ajé? And why was he so deserving of the honors bestowed upon him both in Africa and the New World? In his research, Martínez concluded that Ajé was the son of one of the first kings that resided in Abomey ${ }^{38}$ and of a maiden that, after be ing violated by him, retired to live with her parents in a village of the kingdom. When she gave birth to a son, they sent him to the king s o that he c ould b e w ell cared for a nd properly educated. A jé, upon becoming a man, left the palace and went into the world in search of his mother. He hoped that he c ould garner s ome love, brotherhood and goodness living a mong his mother's people. H e believed that he would feel better, having been given over to help those who were suffering from hunger or lack of shelter. U pon dying, the pe ople made him a demigod and incorporated him into their religion. ${ }^{39}$

In the Yoruba religion, Ajé is recognized as one of 429 de ities. ${ }^{40}$ In the mystery of his ritual, $t$ he de votees t ook $t$ he bl ue of the w aters a s a s acred, pur ifying e lement of his hol y

\footnotetext{
${ }^{37}$ Ibid.

${ }^{38}$ This was the capital city of the kingdom of Dahomey that encompassed what is now the territory of contemporary Benin, as well as the northwestern corner of Nigeria.

${ }^{39}$ These were mostly of the Fon ethnic group.

${ }^{40}$ Carrillo, "En la tierra de los hijos de Ajé."
} 
condition, and they de lighted $\mathrm{w}$ ith the "rocking of the w aves" world in search of his mother. U pon the arrival of the rains, they invoked his presence with a flurry of drum beats. These soundings would calm any thirst that the ground and the crops of his devotees had suffered. It also symbolizes how Ajé interrupted the search he was conducting for his mother to be with and care for his mother's people. ${ }^{42}$ They believe that Ajé, upon his death, was inseparably reunited with his mother in the spirit world.

Among the Yoruba, Ajé is known as Aje Shaluga, and is identified as the god of wealth who confers riches on his worshippers. The name appears to mean either "the gainer who makes to recur," or "the sorcerer who makes to recur." (Aje, sorcerer; aje, earner, or gainer, and shalu, to r ecur.) $\mathrm{H}$ is e mblem is a 1 arge c owry s hell. O ne Y oruba proverb s ays, " Aje S haluga of ten passes $b y$ t he first ca ravan as it co mes t o the m arket, an $d 1$ oads t he 1 ast $w$ ith $b$ enefits;" an d another, "He who while walking finds a cowry is favoured by Aje Shaluga." The large cowry, emblematic of Aje Shaluga, has no value as a medium of exchange. However, the small white cowries could be exchanged for goods and services. A je Shaluga is the patron of dyes and of colors generally and is believed to have originated in the body of Yemaya. ${ }^{43}$

A similarity seems to exist in the following account provided by Ellis of Ajé's birth with the oral tradition passed down from generation to generation in the Sur del Lago of Venezuela:

In some time Odudua, who was the Earth, bore by Obatala, who was the Heavens, a son and a daughter. The son, Oganju, who was dry and barren land, married the daughter, Yemoja, who was the life giving water. They had a son, Orungan, who was the sky between heaven and earth. One sad day when Aganju was far from home, $\mathrm{O}$ rungan $\mathrm{r}$ avished hi $\mathrm{s} \mathrm{m}$ other, $\mathrm{Y}$ emoja. $\mathrm{S}$ he $\mathrm{s}$ prang from hi $\mathrm{m}$ a nd $\mathrm{r}$ an

\footnotetext{
${ }^{41}$ In Venezuela, this motion of the sea is referred to as the "bamboleo." I t is enacted in some dance movements transferred to the fiestas and processions in honor of San Benito.

${ }^{42}$ Martínez, Antecedentes, 81.

${ }^{43}$ Alfred B urdon E llis, Yoruba-Speaking Peoples of the Slave Coast of West Africa: Their Religion, Manners, Customs, Laws, Language, Etc. (London, 1894; republished online, www.forgottenbooks.com , 2007), 43-46 (14 April 2010).
} 
quickly, blindly away. He pursued her and was overtaking her and about to touch her, when she slipped and fell, striking her head against a stone.

The impact s ent jets of water gushing up from her huge breasts. T hese streams joined to form a sweet lagoon. Her huge belly burst open and many orisas (sic) sprang from her. There was Dada, god of ve getables; Shango, god of lightning; Ogun, god of i ron; O lokun, g od o f the s ea; O losa, goddess of 1 agoons; O ya, goddess of the Niger; Osun, goddess of the river Osun; Oba, goddess of the river Oba; O ko, g od o fa griculture; Aje Saluya, god of wealth; S ankpanna, the smallpox god; Orun, the Sun; and Osu, the Moon. ${ }^{44}$

The account of the ravaged Yemoja and the resulting son Aje is widely known in Africa, Brazil a nd V enezuela. In m ost of $\mathrm{S}$ panish-speaking Latin A merica, to i nclude $\mathrm{V}$ enezuela, Yemaya is the proper name for the Divine Mother, while she is known as Yemoja in Bahia and the rest of Brazil. ${ }^{45}$ This powerful female orisha also carries out many different functions and plays many roles in both Afro-Portuguese and Afro-Hispanic belief systems. All of the sundry manifestations of Yemaya go by various s pellings and pronunciations in accordance with the Portuguese or S panish influence on the Y oruba language, ${ }^{46}$ with B astide estimating that there may be at least eight names for her. ${ }^{47}$ The Divine Mother of the Yoruba peoples is analogous to the Roman Catholic Mary, who also operates in many modalities such as Our Lady of Sorrow, Our Lady of Grace, Our Lady of the Blessed Sacrament, Our Lady of the Rosary, etc.

In th e s yncretic b elief s ystems ( Christian-Yoruba m ix) pr evalent t hroughout $t$ he Caribbean and Latin A merica, Y emaya or Y emoja, s ymbolizes the s ea an d is indeed equated with $\mathrm{M}$ ary, the vi rgin mother of J esus $\mathrm{C}$ hrist. ${ }^{48}$ This c learly i ndicates the s upreme hol iness attached to Ajé, establishing him as a demigod in the A frican pantheon. And that he emerged from the sea lends added significance to a people ge ographically torn from Mother A frica and

\footnotetext{
${ }^{44}$ Ibid., 64. See also the account given by Martínez, Antecedentes, 81.

${ }^{45}$ Pierre Verger, Notes sur le Culte des Orisa et Voudun à l'Ancienne Cote des Esclaves en Afrique (Dakar : Institut Français d'Afrique Noire, 1957), 294.

${ }^{46}$ Ibid., 293.

${ }^{47}$ Roger Bastide, Le Candomblé de Bahia (Rite Nagô), (Paris, Mouton, 1958), 146.

${ }^{48}$ Lizette Alvarez, "A fter Y ears of S ecrecy, S anteria is S uddenly M uch M ore P opular, an d P ublic," New York Times, 27 January 1997.
} 
transported against their will across the Atlantic Ocean. They now have a guardian and protector in Ajé while they dwell as strangers in strange land.

That the Ajé attributed to the Imbangala by Martínez was of Yoruba origin poses some problems for the researcher of religion and African culture as it was transported to the Americas and $\mathrm{t}$ he $\mathrm{C}$ aribbean. $\mathrm{T}$ he $\mathrm{Y}$ oruba were $\mathrm{c}$ entered in $\mathrm{w}$ hat is now the nation of $\mathrm{N}$ igeria at $\mathrm{t}$ he confluence of the Niger and Benue rivers, much further nor th than the areas inhabited by the Imbangala from the sixteenth through the twentieth century. This researcher, therefore, needed to find further linkages between the Imbangala and the Yoruba.

In addition to the Imbangala Ajé and the Y oruba Aje Shaluga connection, consider the following commentary from Roger Bastide, a noted French sociologist who specialized in AfroBrazilian c ulture: "Thus the Y oruba thunder-god, S hangô, is i dentified by the Angolans with Zazé, K ibuko, Kibuko K iassubanga; a nd b y the C ongolese w ith K anbaranguanje. S imilarly, Omolú, the Y oruba god of medicine and healing, is identified by the Angolans with Cavungo, Cajanja, and by the Congolese with Quingongo...."49

This observation by Bastide suggests that it was not unusual for non-Yoruba peoples to adopt $\mathrm{Y}$ oruba de ities a s their ow $\mathrm{n}$. V eneration of $\mathrm{Y}$ oruba orishas extended a long $\mathrm{m}$ ost of Africa's west coast, from the Senegambia region in the north to Angola in the south. ${ }^{50}$ As for the name of Ajé, among many of the Fon-speaking peoples of W est A frica, mostly situated in and around the Bight of Benin, it is pronounced Ashé, and is loaded with meanings. ${ }^{51}$ Fon is, like Yoruba and Ewe, a Gbe language that was, and continues to be, commonly used among believers

\footnotetext{
${ }^{49}$ Roger B astide, African Civilisations in the New World (New York: Ha rper and Row, 1972), 109; o riginally published in the French language as Les Amériques noires (Paris: Editions Payot, 1967).

${ }^{50}$ Kiva Fall Mahkete, interview by author. Morgantown, West Virginia, 26 January 2010. Fall Mahkete is a native of Senegal, as well as a colleague and doctoral candidate in the West Virginia University Department of History. He has studied the origins and rituals associated with sundry orishas in Africa and Brazil.

${ }^{51}$ D. M. and J. E. Dos S antos, "Religión y cultura negra," 121. The a uthors make mention of Nago, which is a language based on the retention of some aspects of the Fon vocabulary in parts of Latin America. Nago is spoken during the ritual observances of many syncretic religions in the Western Hemisphere, most notably Santería.
} 
of the Yoruba religion in what is now the contemporary A frican nation of Benin, as well as in parts of the Cameroon, Ghana, Nigeria and Togo. ${ }^{52}$

Ashé carries out an important role as a spiritual force in the theological structure of the Yoruba religion. One of the de fining aspects of the Y oruba religion s hared throughout W est Africa is its initiation process. The Yoruba religion was acquired, transmitted and developed in very specific ways. Adherents participate in rituals whereby they establish a direct relationship with the orishas, from whom they gradually receive, absorb and develop mystical and symbolic powers. The acquisition of these powers allows them to integrate and identify with the elements of a dynamic religious system. The adherents are now capable of going out into their respective communities and mobilizing these spiritual powers on behalf of the people. The orishas, like the Catholic saints, provide a bridge be tween the s pirit and temporal w orlds, a s w ell a s the past, present and future. ${ }^{53}$ The Ajé/Ashé p ower is vital to carrying out all the rites of the Yoruba religion. It i s a f orce $\mathrm{t}$ hat $\mathrm{c}$ an onl $\mathrm{y}$ be a cquired $\mathrm{t}$ hrough i nfusion or $\mathrm{c}$ ontact a nd $\mathrm{c}$ an be transmitted to both objects and human beings. Essentially, Ashé is an invisible force, magic and sacred, imparted to the adherents of the Yoruba religion by the orishas. ${ }^{54}$

Among s ome f emale pr actitioners of the $\mathrm{Y}$ oruba $\mathrm{r}$ eligion, s ometimes $\mathrm{r}$ eferred $\mathrm{t}$ o a $\mathrm{s}$ "witches," the name Aje is still retained for th is power. A witch, employing Aje power, can morph into a screeching bird and also possess the bodies of others, providing they are not strong and in good health, in so far as the potential victims have more resistance. W hen the witches wish to employ the Aje force, they must first gather in secret and work collectively. They can identify the other witches by coating their eyes with a special herbal medicine, thus giving them

\footnotetext{
${ }^{52}$ Paul E. Lovejoy and David V. Trotman, Trans-Atlantic Dimension of Ethnicity in the African Diaspora (London: Continuum, 2003), 21.

${ }_{54}^{53}$ D.M. and J. E. Dos Santos, “Religión y cultura negra,” 120.

${ }^{54}$ Ibid., 121.
} 
unique powers of visual discernment. If they turn to the dark side of this force, in the form of birds they can attack men and kill them by sucking their blood. ${ }^{55}$ The draining of a victim's blood corresponds to the cannibalistic tendencies of the Imbangala.

On the other hand, the exercise of magic power by the men is known as Ashé. These "wizards" a re as sociated with w ealth. They are not ed for living in large hous es without e ver having to w ork for them. They a re be lieved to have a massed their w ealth by stealing it from hiding places that they were able to detect with their magic powers. ${ }^{56}$ This also adheres to the Imbangala ethos of pillaging their neighbors' lands for anything usable in their war camps.

Like $t$ he Imbangala, $\mathrm{p}$ eoples up a nd dow $\mathrm{n} t$ he $\mathrm{W}$ est $\mathrm{A}$ frican $\mathrm{c}$ oast e njoyed $\mathrm{s}$ ome familiarity with $\mathrm{Y}$ oruba $\mathrm{r}$ eligion a nd tr aditions. O labiyi Babalola $\mathrm{Y}$ ai, a $\mathrm{n}$ ambassador from Benin to the United Nations, asserts that, "Yoruba religion became global by sharing its orisha with the immediate, W est A frican n eighbors of the pe oples who have come to be collectively designated as Yoruba, and by adopting some of their deities." ${ }^{57}$ He adds that avatars of almost every Yoruba orisha can be identified in the pantheon of nearly any given W est A frican ethnic group. A lso, with regard to the di ffusion of Y oruba r eligious traditions, he thinks that more attention and study of Yoruba encounters with Central Africans is sorely needed. ${ }^{58}$

\footnotetext{
${ }^{55}$ Teacher in Abeokuta (Yoruba), as told to J. P. Crazzolara, "The A frican Explains Witchcraft," Journal of the International African Institute 8:4 (October 19 35): 54 8. C ontemporary a nthropologists would $\mathrm{r}$ efer $\mathrm{t}$ o t he practitioners of traditional African religions as shamans rather than "witches" or "wizards," as they were often called back in the 1930s, even in the above-cited translation from the Fon language provided by this esteemed academic journal, now published simply as Africa by the same organization.

${ }_{57}^{56}$ Teacher in Abeokuta, "African Explains Witchcraft," 548.

${ }^{57}$ Olabiyi Bablola Yai, "Yoruba Religion and Globalization: Some Reflections," Cuadernos Digitales: Publicación Eléctrica en Historia, Archivística y Estudios Sociales 15 (October 20 01), La Universidad de Costa Rica, http://historia.fcs.ucr.ac.cr/cuadernos/c15-his.htm (28 January 2010).

${ }^{58}$ Ibid.
} 
As not ed, the w ork o f e stablishing t hese c onnections ha s a lready b egun, especially concerning the extensive transfer of Yoruba religious systems and traditions to the Kongo, ${ }^{59}$ a group that e ncountered the I mbangala on num erous oc casions. ${ }^{60}$ To t ake an other example, Queen Nzinga of the Mbundu peoples of Angola, for example, beseeched a "spiritual Àjé force" to assist in her kingdom's battles with the Portuguese invaders, against whom she also contracted and deployed a contingent of Imbangala warriors. ${ }^{61}$

As ev idenced b y Queen $N$ zinga, $t$ here i s a certain $p$ racticality to $t$ raditional A frican religions, whose followers, like the Y oruba peoples, pl ace an emphasis o n the "here and now rather than the a fterlife," and tend to focus on "natural forces." 62 According to a New York Times correspondent, “Each (Yoruba) d eity represents an a spect of na ture, like thunder, and a human c haracteristic, 1 ike pow er." ${ }^{63}$ As a s piritual force, Àjé m anifested a s both $\mathrm{m}$ ale and female av atars throughout s undry W est A frican kingdoms. ${ }^{64}$ Therefore, it was noted that the Yoruba priests of Àjé in Africa ${ }^{65}$ and the Santería practitioners of Ajé in America ${ }^{66}$ could be of either sex. These priests helped people to resolve their day-to-day problems by consulting with Àjé. T he p riests of S anteria an d o ther s yncretic s ects, as they have co me to ev olve, ar e $n$ ot Catholic priests, and are not endorsed in any way by the Roman Catholic Church. Their rituals, for the most part, are held in homes rather than chapels, churches or temples. ${ }^{67}$

\footnotetext{
${ }^{59}$ Teresa N. W ashington, Our Mothers, Our Powers, Our Texts: Manifestations of Àjé in Africana Literature (Bloomington: Indiana University Press, 2005), 57, 58, 67, 80, 84, 85, 88, 298.

${ }^{60}$ Woodson, "Notes on the BaKongo," 423, 430.

${ }^{61}$ Washington, Our Mothers, 58.

${ }^{62}$ Lizette Alvarez, “After Years of Secrecy,” (New York Times).

${ }^{63}$ Ibid.

${ }^{64}$ Washington, Our Mothers, 56-57.

${ }^{65}$ Teacher in Abeokuta, "African Explains Witchcraft," 548.

${ }^{66}$ Washington, Our Mothers, 56-57.

67 "The Lure of Santería," Awake!, 8 July 2000. This is a publication of the Watchtower and Bible Tract Society of New York, Inc., M. H. Larson, President.
} 
This harnessing of Yoruba rituals for application in the New World formed the basis of a new theology that pe rmitted c ontinued e fforts at $\mathrm{w}$ orshipping the orishas in acco rdance $\mathrm{w}$ ith ancient African beliefs. African slaves assigned to Catholic saints dual identities. Each Catholic saint $\mathrm{c}$ orresponded t o a $\mathrm{n}$ A frican d eity $\mathrm{w}$ ith pa rticular $\mathrm{c}$ haracteristics a nd pow ers. O nce the Africans $\mathrm{w}$ ere $\mathrm{s}$ ituated i $\mathrm{n} \mathrm{t}$ he $\mathrm{N}$ ew $\mathrm{W}$ orld, $\mathrm{t}$ he $\mathrm{F}$ rench, $\mathrm{P}$ ortuguese a nd $\mathrm{S}$ panish $\mathrm{c}$ olonial administrators and clerics tried to force them to abandon their traditions completely. In order to circumvent this, the A fricans opted to create new forms of worship out of elements taken from both the Catholic and Yoruba religions, and this melding of religious practices became known as syncretism. ${ }^{68}$

The A fricans put the faces of Catholic saints to all of their own deities, including Ajé. Therefore, all of the anti-African philosophy and ploys of the Roman Catholic Church failed to bury Ajé. He lives on in hearts of the A fro-Venezuelans and other black South Americans and Afro-Caribbeans, while the image that these s ame people venerate is that of $\mathrm{S}$ an B enito. O ne follower of S antería expressed this idea succinctly when he explained that, "Syncretism al lows us to w orship the Catholic g od on the a ltar, but what we see is the A frican god behind it." ${ }^{, 69}$ Therefore, Ajé is s een as the au thentic power that makes possible the miracles, at least in the eyes of most Afro-Zulians. In the next section, both the historical and mythic personage of San Benito are examined, and the linkages between Ajé and San Benito are further explored.

\section{San Benito}

Long before his devotees ever referred to him as "San Benito," he came into the world of humble station. His story begins in the first quarter of the sixteenth century, when a man child came into the world near the then small Italian town of Manassari, situated on a Mediterranean

\footnotetext{
${ }^{68}$ Ibid.

69 "Lure of Santeria," Awake!
} 
island to the south of the boot. He was black, the son of some slaves that served a rich estate owner, Señor Vicenzo Manassari, or some say Manasseri, in whose family's honor the town was named. Even though San Benito's parents, being of Ethiopian descent and the property of Señor Manassari, were legally not entitled to keep their s on, the estate owner felt pity on the couple, and because of their pleadings and honest service to him, allowed the family to keep and care for their son on the condition that his life be devoted to the service of God and the Holy Church. ${ }^{70}$

There a re also s ome ot her 1 egends. O ne s ays t hat w hile $\mathrm{S}$ an Benito's $\mathrm{f}$ ather was Ethiopian, his mother was an Italian queen. And yet another states that San Benito was white, but that he had asked God to blacken his skin in order to escape the temptations of women. ${ }^{71}$

It has been established that his parents, Cristóbal and Diana Larcán, did not want to have any children because they would end up as slaves, like they were. Upon knowing that this slave couple had made up their mind concerning this matter, the master swore to them that at least the first of their children w ould not be born a slave. And then, in 1524, Benito, or Bendetto in Italian, came to see the light of the world. His name means "blessed one."72

The small child of Cristóbal and Diana lived the life of a campesino and pastor of sheep. In his late teens, he became s piritually a wakened, and de cided to join the Franciscan religious order. There, he worked as a cook in a convent. While he wasn't a slave, we have to keep in mind that his parents continued to work under the orders of Señor Vicenzo Manasseri. The little money that Benito would receive for his services as a cook he would keep be cause he thought that if he saved enough, perhaps his luck and the luck of his parents w ould take a turn for the better. Nevertheless, as he grew in stature and wisdom, he began to feel closer to the work of the Franciscans, and he wanted evermore to live a life of solitude and penitence. He was beginning

\footnotetext{
${ }^{70}$ Crespo, Venezuela: Tierra Mágica (pamphlet).

${ }^{71}$ Ibid.

${ }^{72}$ Ibid.
} 
to lose interest in money, as well as other material things. At the same time, as he continued in the field and the convent, engrossed in his labors and metaphysical contemplations, there passed by on e $\mathrm{d}$ ay a f riar. T his $\mathrm{r}$ eligious br other $\mathrm{s}$ topped $\mathrm{t} \mathrm{o} \mathrm{c}$ hat i $\mathrm{n}$ frankness $\mathrm{w}$ ith Benito, a nd convinced him to leave and to live in the mountains with him as part of the Brotherhood of the Monks of San Francisco de Assisi. Much time passed as Benito dedicated his life to the order. There is no doubt that he enjoyed the religious life. ${ }^{73}$

Nevertheless, there was some political turmoil in the group. It was self-destructing, but Benito did not want to wait around for the brothers to disband. Instead, he joined up with the Little Observing Brothers, a nother organization in the Franciscan order. That was in Palmero, Italy, and it was also there, because of his charitable work, that Benito became well known for enormous generosity. First, he was known as Fray Benito de Palmero and later, when the Pope Pío VIII declared him a saint, San Benito de Palmero, the name that he has come to be known as forevermore. ${ }^{74}$

He has also, in some circles, co me to b e called $\mathrm{S}$ an B enito d e F ratello, $\mathrm{S}$ an $\mathrm{B}$ enito el Moro or $\mathrm{S}$ an Benedito. In s pite of carrying on a life of privations and sufferings, he always flashed a brilliant smile. N obody, or almost no one, knew of his physical pain. He died at the age of 65 , on the $4^{\text {th }}$ of April, 1589, at 7 p.m. All of Palmero came to pay their 1 ast respects before his open coffin. With his habits and his few possessions they fabricated religious relics and keepsakes of his glorious past for the world to remember his smile. So innumerable were his miracles, they a re unc ountable. A nd he $\mathrm{w}$ as most $\mathrm{w}$ ell know $\mathrm{n} f$ or $\mathrm{t}$ he $\mathrm{c}$ uring of the $\mathrm{s}$ ick, alleviating the a fflicted, pr oviding hos pice for the $\mathrm{d}$ ying, pr otecting the ha rvests a nd $\mathrm{m}$ aking

\footnotetext{
${ }^{73}$ Ibid.

${ }^{74}$ Ibid.
} 
businesses prosper. But while he worked so many miracles, he was also apt to castigate those who failed to keep the promises they made to him. ${ }^{75}$

The Spanish brought San Benito to the Americas along with dozens of other prominent Catholic s aints, b ut $r$ ight a way $S$ an $B$ enito be came $r$ ecognized a s the $p$ atron of the $S$ panish colonial blacks because this sacred personage was as black as they were.

The Venezuelans believe in him with great fervor. T he slaves invoked his pow er through the religious rites and ceremonies in those days that their masters would allow them to celebrate with their African dances in order to at least feel "temporarily free," until they had to go back to work. Thus, San Benito is equated with liberty among the Afro-Venezuelans. His fiestas keep kindled the memory of African ceremonies, dances and traditions veiled in a cloak of Catholicism. In the colonial $\mathrm{t}$ imes, $\mathrm{t}$ he $\mathrm{bl}$ ack $\mathrm{s}$ laves $\mathrm{c}$ ontinued $\mathrm{t} \mathrm{o} \mathrm{c}$ elebrate $\mathrm{S}$ an $\mathrm{B}$ enito $\mathrm{t}$ hrough pr ocessions, candlelight vi gils, a nd s pecial prayers on hi s s aint da y of $29 \mathrm{D}$ ecember. T hese cel ebrations constitute a mixture of sacred and profane religious ritual: European, African, Native American, Christian and Animist all at the same time. The celebration in honor of the Black Saint begins with the first rains and ends in the summer, from the first Saturday in October until the first of January. ${ }^{76}$

The non-sanctioned liturgical cycle of S an Benito celebrations actually closes on El Día de los Reyes Magos, or Day of the A strologer Kings, on the Sixth of January. Chimbángueles sound throughout the entire day as the saint bids farewell to all of his devotees. In Gibraltar, after the saint is resituated in his chapel, the assembly is initiated in sacramental plays, where all of the people serve as both actors and spectators. W hile this last activity is relatively recent as

\footnotetext{
${ }^{75}$ Ibid.

${ }^{76}$ Martínez, Como Bailar, 7-9. Details of all the activities pertinent to San Benito, profane and sacred, are explained based up on an interview conducted by Martínez with Encarnación Estrada, the director of San Benito festivities in the village of Palmarito in 1956.
} 
far a s be ing allowed to take pl ace in the $\mathrm{C}$ atholic $\mathrm{Church}$, be ing i nstituted about one hundred years ago, it has been tolerated by the church because it served as a channel for directing pagan souls back in its direction. In order to fully appreciate the me aning of these closing activities, Martínez has studied the Chimbángueles in the context of four a spects: Divinity, Governance, Orchestra and the Human Aggregate. The last category represents the vassals or devotees of San Benito $t$ hat $b y t$ heir $A$ frican he ritage a nd e nduring $f$ aith ha ve assumed $t$ he $r$ esponsibility of watching o ver an $d$ taking ca re of the $b$ asic el ements n eeded to co mplete the rituals. ${ }^{77}$ These include $\mathrm{s}$ uch a ctivities a $\mathrm{s}$ c onstructing th e $\mathrm{d}$ rums, f lutes, $\mathrm{m}$ aracas, an $\mathrm{d} b$ atons, as $\mathrm{w}$ ell as recruiting and forming new vassals. ${ }^{78}$

Speaking of the importance of the San Benito festivities for the people, Martínez stated the following:

The religious fervor to which the people celebrate the First of the Year and their testimonies given permit me to affirm the following: The Chimbángueles of the First of January soar to the heavens on the day that Mawo-Lisa created the world, there in Africa, and it represents the resumption of time, when life began for our ancestors. W ith these Chimbángueles "pure time" is restored, that which existed in the moment of the creation of the w orld. It is not a pa gan $t$ ime in which routinely we can return to. Therefore, the regression to pure time invites us to renew ev erything that in the pr evious year ha $\mathrm{d}$ be en poorly us ed or de fective. Man and all things are created anew, reborn each First of January. W e are freed from times past, reconstructing ourselves as more pure in creative power and free, as men ought to be, before the supernal presence of Ajé or San Benito, to whom the Chimbángueles sound out in their honor. ${ }^{79}$

Martínez $f$ urther ex plained $t$ he $s$ ignificance of $t$ hese cel ebrations $t$ o $t$ he A fro-Zulian community, not ing that $\mathrm{it} w$ as $\mathrm{c}$ onsidered $\mathrm{b} y$ all of $\mathrm{them}$ a s a $\mathrm{n}$ obl igation of $\mathrm{t}$ he African celebration of "Passing Time." In other words, the festivities represent the nullification of poorly

\footnotetext{
${ }^{77}$ Martínez, Como Bailar, 10. Martínez views the Angolan drums as the heart of the festivities, seeing them as "sacramental el ements" o $\mathrm{r} 1$ iving o racles o f $\mathrm{t}$ he I mbangala a ncestors. $\mathrm{H}$ e ex plains $\mathrm{t}$ hat $\mathrm{t}$ he $\mathrm{v}$ ery word, Chimbángueles, is an Hispanic term applied to the name in which the Imbangala of Angola refer to themselves, Aimbanglé.

${ }^{78}$ Ibid.

${ }^{79}$ Martínez, Como Bailar, 8.
} 
used time, as well as the faults and failings of men. In this period of Passing Time, the followers of the saint take advantage of the opportunity to renew their search for a more dignified society. They b elieve that not onl y A jé/San B enito, but other A frican orishas are w orking together to help them create a better society, or to one day dismantle it completely and reconstruct it in the image of a New A frica. Martínez qualified this by declaring that on the First of J anuary, "we

make of ourselves new and more dignified universal beings." ${ }^{80}$ In the next section, the ease at which this syncretic process of the melding of Ajé with San Benito was carried out is examined in the context of the European efforts directed towards the evangelization of blacks back in West Central Africa.

\section{Propagation Efforts of the Capuchin Order}

Historical records indicate that Christianity in West Central A frica was introduced from the top down. The A frican King of the Kongo, Garcia Alfonso II, in an e ffort to reassert his independence from Lisbon, in $1646 \mathrm{~s}$ ent a 1 etter t o the P ope i nviting $\mathrm{m}$ ore non-Portuguese Catholic m issionaries, Italian and $\mathrm{S}$ panish $\mathrm{C}$ apuchins, t o take up residence in hi s dom ains. ${ }^{81}$ Duffy points out that the shortage of Portuguese missionaries was always a problem in Angola. Even when P ortugal had a surplus of mis sionaries, few w ere willing to commit to a te rm of service in Africa; and of those that did, few could be counted on to complete their tasks. ${ }^{82}$ Said the Bishop of Angola in 1773 regarding Portuguese missionaries in his ecclesiastical jurisdiction: "Some c ome t o s eek $\mathrm{t}$ heir $\mathrm{f}$ ortunes a nd pu rsue $\mathrm{t}$ heir ow $\mathrm{n}$ i nterests.... ot hers $\mathrm{s}$ atisfy $\mathrm{t}$ heir passions.... others flee from the discipline of their prelates.... And from these greedy, expatriate, rebellious, and libertine men what else can be expected than the spread of vice and scandal in

\footnotetext{
${ }^{80}$ Ibid., 8-9.

${ }^{81}$ Duffy, Portuguese Africa, 67.

${ }^{82}$ Ibid., 106.
} 
which this land is already buried." 83 The dedication of the Italian Capuchins was most notable, however, a nd put to s hame the weak e fforts of e vangelization put forth $\mathrm{b} y \mathrm{t}$ he $\mathrm{P}$ ortuguese clergy. ${ }^{84}$

The history of the Capuchin order in the Congo and Angola dates back to 1608. In that year, the Manicongo Dom Alvaro II requested that missionaries be sent to his realm to introduce his s ubjects t o the $\mathrm{C}$ hristian r eligion. By 1620 , the $\mathrm{P}$ ope ha $\mathrm{d}$ s anctioned the c reation of the Apostolic Prefecture of the Congo. The oversight of this pr efecture w as trusted to the Italian Capuchin friars, who would report to the Bishop of Angola. The first mission was dispatched to Africa in 1640, but was blocked by Lisbon authorities. Then, in just five years, another mission was dispatched to the Congo from Spain, thus bypassing Portugal altogether. This mission of the Italian $\mathrm{C}$ apuchins $\mathrm{m}$ et $\mathrm{w}$ ith phe nomenal s uccess. B y 1648, ov er 45,0 $00 \mathrm{~A}$ fricans ha $\mathrm{d} \mathrm{b}$ een converted and baptized into the Roman Catholic Church. ${ }^{85}$

The evangelization w ork of the Capuchins in the Congo and Angola continued, de spite protests by King João of Portugal that the activities of the Italian order were und ermining both his authority and sovereignty by their consorting with other Europeans in the area. In 1649, for example, the $\mathrm{P}$ ortuguese ki ng o rdered the $\mathrm{C}$ apuchins to de clare their fidelity to $\mathrm{h}$ im a nd to Portugal or be expelled from Africa. Under duress, they did so swear, and were then allowed to take up r esidence in Luanda and Massangano to further the mission w ork in Angola. W ithin a relatively short time, eight mis sions were es tablished. However, relations with the Portuguese remained tenuous. One of the factors that put the Capuchins under intense Portuguese scrutiny was $t$ heir e xpressed de sire $t$ o e xpand $t$ he pr iesthood $t$ hrough $t$ he $r$ ecruitment of A fricans. Christian communities were being established at an ever increasing rate, but many of the white

\footnotetext{
${ }^{83}$ Quoted in J. Alves Correia, A dilatação da fé no império português , 2 vols. (Lisbon, 1936), II:40-41.

${ }_{85}^{84}$ Duffy, Portuguese Africa, 106.

${ }^{85}$ Ibid., 115.
} 
missionaries s ent to manage the $\mathrm{p}$ arishes there were w eakened or $\mathrm{d}$ ying off from $\mathrm{m}$ alaria and dysentery. In addition, the ravages of the slave trade impeded their work, and by the start of the eighteenth century, the order in Angola had begun to wane. ${ }^{86}$

Duffy does state, however, that the Capuchins were "diligent men, usually selected with care by their s uperiors for $\mathrm{W}$ est A frican assignments." $\mathrm{H}$ e a dds that a lthough they preferred working in coastal Angola, the Capuchins were willing to serve for long years of isolation in the heart of the Congolese interior. "Although they were known to deal in slaves and to work with them," asserts Duffy, "their record was probably the best of any mission order working in Africa until the present century."

In 1 ight of this r emarkable hi story, it c omes a s no s urprise that Chourio c hose Italian Capuchins for the chapel he was constructing at Perijá. T hus there remains a high probability that his c ontacts with the Imbangala may have come a bout through his connections with the Capuchin order in Angola. The Imbangala contingent that went with Chourio to Venezuela may well have been Christianized by the $\mathrm{C}$ apuchins, at le ast to a limite $\mathrm{d}$ d egree. But b ecause the Capuchins did not operate any catechism schools in the interior regions, and because there were no missionary sisters to educate the women, the Imbangala, like other A fricans in contact with the Europeans, may not have been sufficiently grounded in the Roman Catholic religion to resist the i nfusion of A frican be liefs i nto $t$ heir ne wly emerging $t$ heological pe rspectives, $t$ hereby providing a $\mathrm{n}$ account $\mathrm{f}$ or $\mathrm{t}$ he e volution a nd diffusion of $\mathrm{t}$ he $\mathrm{A}$ jé/San $\mathrm{B}$ enito $\mathrm{s}$ yncretism throughout Venezuela. ${ }^{88}$

\footnotetext{
${ }^{86}$ Ibid., 116.

${ }^{87}$ Ibid., 117.

${ }^{88}$ Ibid., 131.
} 


\section{Diffusion}

It was in the oppressive environment surrounding slavery in Venezuela in which Africans in the Sur del Lago Maracaibo region found themselves turning to San Benito for relief, and with the later infusion of an Imbangala contingent (third wave) with an affinity for Ajé, it is easy to understand how this syncretic belief system evolved and flourished. A round the be ginning of the seventeenth century, in Gibraltar, a small Venezuelan pueblo in the Sur del Lago Maracaibo, the ow ners of the big plantations (hacendados) began to take an interest in the importation of African slaves. The slave traffic was being carried out in the Americas since the first quarter of the s ixteenth c entury, pr imarily in $\mathrm{C}$ artagena, $\mathrm{N}$ ueva $\mathrm{V}$ eracruz, $\mathrm{P}$ ortobelo, La $\mathrm{H}$ abana, $\mathrm{P}$ uerto Rico, Carúpano and La Guaira. ${ }^{89}$ Because of the early w ork of the Capuchins in A frica, it is highly probable that these e arly A fricans in the Sur del Lago shared s ome know ledge of S an Benito, but not ne cessarily $m$ aking a c onnection $w$ ith A jé, a $t 1$ east unt il th e imp ortation of Imbangala in the area by Chourio.

The big land ow ners of the S ur del Lago di strict looked at the hug e p rofits their Latin American neighbors were garnering because of the slave trade, and also wanted to participate it. To begin with, they imported just three hundred slaves, but wanted to be assured that these came from different regions of Africa. They did this in order to lessen the probability of conspiracies and upr isings a mong the s lave c lass. They wanted to put these A fricans to work in the big houses (haciendas) and fields of the great cacao and coffee plantations of northwest Venezuela. They also did not want any of the new s laves to be speakers of S panish or Portuguese. They feared that the new on es might be infected w ith seditious ideas by those al ready ac culturated slaves on the plantations. ${ }^{90}$

\footnotetext{
${ }^{89}$ Balza Santiago and Rangel, "Mucuchíes honra a San Benito,” 79.

${ }^{90}$ Ibid.
} 
Great pains were also taken to see that new slaves were kept far away from other slaves already on the plantations who were suspect of speaking the same, or similar, African languages, or that might pertain to the same or similar indigenous African culture. It was also in the minds of the big hacendados that the A fricans w ere somehow "less lazy" than the $\mathrm{N}$ ative American field w orkers and that the blacks were, by and large, more suitable for the rigors of w ork that would have to be done in the humid and hot lands of the tropics. The black people were much more capable of resisting disease than the Native Americans; and besides, the Africans were not entitled, under S panish 1 aw, to enjoy the s ame legal protections that had come to be nefit the Native A mericans, in good pa rt due to the a uspices and intervention of the $\mathrm{R}$ oman $\mathrm{C}$ atholic Church. ${ }^{91}$ In the midst of these stifling conditions, the Afro-Zulians appropriated San Benito as their own. They did this because the Imbangala arrivals succeeded in organizing most of the Sur del Lago blacks from various plantations and imparting to them an African identification with Ajé and associated magic pow ers. In addition, $\mathrm{S}$ an B enito was the only saint who could give some spiritual me aning and sustenance in their lives. F or although $\mathrm{S}$ an Benito was black, his veneration was at least tolerated by the Europeans.

The further development of the Ajé/San Benito connection in Venezuela is explored by Martínez, who provides various oral recitations passed on by elders in the Sur del Lago. One of these is Olimpíades Pulgar"2 , a.k.a. "Pía," who on various occasions gave an account to Martínez of how the priest López of Gibraltar ${ }^{93}$ was the one who initiated him into the faith, i.e. to love and believe in San Benito. This priest related several accounts to Señor Pulgar of the legends and rituals surrounding San B enito that have e merged throughout Venezuelan history, who in turn passed the information on to Martínez and other interested parties.

\footnotetext{
${ }^{91}$ Ibid.

${ }^{92}$ Martínez, Como Bailar, 7.

${ }^{93}$ A predominantly black community in the Department of Sucre in the Sur del Lago district of Zulia State.
} 
For example, the festivities in honor of $\mathrm{S}$ an B enito in the Sur de $1 \mathrm{~L}$ ago village of $\mathrm{S}$ an Pedro, little by little, and over the years, have managed to extend to other communities in the municipalities of Sucre and Baralt of Zulia State, and Justo Briceño of Mérida State. And by the nineteenth and twentieth centuries, San Benito celebrations even extended to communities in the states of Trujillo, Lara, Falcón and Portuguesa. This diffusion of the sect of San Benito followed various na tural pa ths that included contact and/or c ommercial relations within the ar ea of the chimbángueles. These contacts and/or relations were varied, but mostly carried out through the activities of fishermen and peasants. ${ }^{94}$

The cas e o $\mathrm{ft}$ he $\mathrm{f}$ ishermen o $\mathrm{ft}$ he $\mathrm{n}$ orthern an $\mathrm{d}$ eas tern coasts of Lake $\mathrm{M}$ aracaibo is particularly illustrative of this point, for during certain times of the year they go to the southern portions of the 1 ake in search of $\mathrm{s}$ pecial $\mathrm{f}$ ish, i .e. cardúmenes de manamanas, bocachicos, armadillos, bagres and doncellas, $\mathrm{w}$ hence $\mathrm{t}$ hey co me i $\mathrm{n} \mathrm{cl}$ ose co ntact $\mathrm{w}$ ith A fro-Zulian communities in the r egion. T he $\mathrm{c}$ ontacts thus engendered ove $\mathrm{r} t$ he $\mathrm{c}$ enturies $\mathrm{w}$ ith $\mathrm{t}$ he $\mathrm{black}$ people of the municipality of Sucre have allowed these fishermen to gain an intimate knowledge of the fiestas in honor of San Benito. These would include not only the chimbángueles, but also the gaita of Tambora ${ }^{95}$ and the Tamolargo or Guariré (the dance of San Pascual Bailón). ${ }^{96}$ In spite of being mostly mestizos, a m ixture of Native American with Canary Islanders and some peninsulares, the fishermen were generally considered to be a poor and oppressed people. Their situation oriented them to become followers of Santa Lucía and San Benito, saints that according to $\mathrm{C}$ atholic tradition w ere the protectors of paupers and s laves. Little by little they began to venerate these saints, ba sed on $t$ he $c$ ustoms and traditions of the bl ack s laves they came into close contact with on the southern shores of the lake. M any of the fishermen erected altars in

\footnotetext{
${ }_{95}^{94}$ Martínez, Como Bailar, 20.

${ }^{95}$ Folkdances set to an early type of "rap," accompanied with African drumming.

${ }^{96}$ It takes 32 people to carry out this street dance, apart from the drummers who walk behind them and play.
} 
honor of Saint Lucía and also began to play drums in honor of S an B enito. Examples of this diffusion by the fishermen are found in Santa Rosa de Agua, where Saint Lucía and San Benito are venerated; in Caño Sagua in the municipality of Páez; in Concha, Ologa, El Congo Mirador and other pueblos of the municipalities of Colón and Catatumbo, in Barranquitas and Potreritos in the municipalities of Perijá and Urdaneta. ${ }^{97}$

Another area of intense cultural diffusion is among the peasants of Trujillo. G enerally, the a gricultural a nd 1 ivestock pr oduction of the pe oples of the s outheast of $Z$ ulia $S$ tate, b y tradition from the earliest of colonial times, left by the port of Gibraltar, and at the start of the twentieth century, by Bobures. This contact was equal to that of the fishermen in getting close to San Benito, and little by little the people in these regions began to play their drums. Also, it is necessary to point out that La Ceiba is the port of Trujillo that in the colony be longed to the cantón of Gibraltar, where the custom existed of m aking the chimbángueles. F rom here, on e goes up to E1 Muro, Santa Isabel, and Dos de Febrero, among other pueblos. A lso, the legend and adoration of S an Benito persists from colonial times to the present in the area round about Río Poco. ${ }^{98}$

Thereby, the diffusion of the cult of S an B enito by fishermen and peasants al lowed for the legends and rituals surrounding this black saint to extend to all areas of Venezuela. Even indigenous pe oples ( Native A mericans) i ncorporated S an Benito i nto their a lready e xpanded pantheon of de ities. In the next s ection, this inclusion of $\mathrm{S}$ an $\mathrm{B}$ enito into a mix of $\mathrm{A}$ frican, European and Indigenous be lief s tructures i s e xamined, a long w ith the e mergence o f ot her multicultural syncretism.

\footnotetext{
${ }_{97}^{97}$ Martínez, Como Bailar, 20.

${ }^{98}$ Ibid., 21.
} 


\section{African-European-Indigenous Syncretism}

The A frican-European $\mathrm{r}$ eligious $\mathrm{r}$ ituals $\mathrm{w}$ ere $\mathrm{c}$ arried o ut $\mathrm{w}$ hile $\mathrm{s}$ ome of th $\mathrm{e} \mathrm{C}$ atholic authorities t urned a blind e ye. $\mathrm{T}$ o assure the penetration of $\mathrm{C}$ hristianity among the $\mathrm{r}$ ecently arrived Africans in the Sur del Lago, the missionaries pe rmitted them to incorporate s ome of their traditional $\mathrm{c}$ eremonies in to the Catholic feast da ys. A $\mathrm{n}$ e qual $\mathrm{c}$ omplacency $\mathrm{w}$ as $\mathrm{s}$ hown toward $\mathrm{N}$ ative A merican $\mathrm{r}$ ites, $\mathrm{w}$ ithout s trict compliance to th e e cclesiastical $\mathrm{r}$ ules a nd regulations established be forehand on $t$ he Iberian P eninsula. In the sixteenth century with the arrival o $\mathrm{fthe} \mathrm{S}$ paniards, the s ocio-cultural ha bitat of the pe ople of M ucuchíes unde rwent a significant transformation of its religious practices. The Spaniards imposed a new doc trine that while intending to abolish the older belief systems, unconsciously, and over time, served to meet the s piritual ne eds of the indigenous T imotes. New gods $\mathrm{c}$ ome to replace the autochthonous gods, who r emained a matter of w orship and hope for the ne w s ociety that de veloped in the colonial pe riod unt il t oday. M ucuchies, 1 ike the e ntire $\mathrm{R}$ angel $\mathrm{M}$ unicipality, $\mathrm{p}$ ossesses a $\mathrm{r}$ ich cultural heritage. Within the context of its customs and traditions, both religious and folkloric, the feast in honor of San Benito came to form the focus of a comprehensive program of religious activities in which other saints were also venerated. The festivals for the black saint have turned out to be an economic boom for Mucuchíes, in addition to providing an excellent excuse for the people of the a rea and the rest of V enezuela to vi sit and spend their m oney in typical to urist activities. Thus, it is noted that even in the remote Andean village of Mucuchíes in Mérida State, by the last days of the eighteenth century the custom of dancing before the sacred images of the orishas/saints, and of taking these images out of their temples in great processions had al ready been well established. ${ }^{99}$

99 Balza Santiago and Rangel, "Mucuchíes honra a San Benito,” 73, 74. 
Examples of such syncretism are to be found in various theocratic or ganizations which delineate the responsibilities for carrying out sundry ceremonies in the societies of the saints. In the $\mathrm{s}$ ocieties d edicated $\mathrm{t}$ o $\mathrm{S}$ an $\mathrm{B}$ enito, as signments ar e $\mathrm{m}$ ade for the ch ief o rganizer (mayordomo), the first captain, the captain of the plaza, the captain of the brigade and the local commanders (mandadores). ${ }^{100} \quad$ These i ndividuals $\mathrm{w}$ ere charged $\mathrm{w}$ ith di recting the religious festivities, whereby the drums, the maracas, the dust that is kicked up, the joy of the dancers, the marches, the bright uni forms and the songs of praise added great color. But all of this did not just happen spontaneously. There is a government, theocratic if you will; and it is known as the Government of San Benito. It began with the so-called cofradías, religious societies created by order of the king of S pain, who m embership was open to all, including those from all of the marginalized groups, like the slaves, free blacks or even the runaway blacks (cimarrones). They come together united un der the protection of $\mathrm{S}$ an Benito and the Catholic Church. T oday, the vassals of San Benito not only secure limousines and organize processions and pilgrimages, but take care of the sick and the burying of the dead in their respective communities. They assist at funerals an d s pecial prayer s essions (novenarios), a s well as in confronting together with the people the unresolved issues of their respective communities, exasperated by poverty. ${ }^{101}$

The patron saint days are well heeded. The celebrants pay particular attention to every detail. They are celebrated with pomp and circumstance. The statues of the saints, or images, are dressed up in the clothing indigenous to the area of the celebrants. S ome of the vassals are wielding whips. Everything is leading to a big blowout manifested in banquets and the various functions of agricultural and religious collectives. The pagan origins of some of these activities

\footnotetext{
100 Ibid., 84.

101 Miguel Acosta S aignes, Vida de los esclavos negros en Venezuela (Valencia, V enezuela: V adell H ermanos, 1984), 224, 225.
} 
are, of course, shrouded in pre-Christian times of a remote past, both A frican and indigenous. Nevertheless, they continue to generate a lot of excitement.

The cofradías that manage these celebrations w ere very num erous once upon a time in Europe, and especially in Spain. From these cofradías, the societies sprang up. These cofradías were more like small trade unions than anything else. Miguel Acosta Saignes is one Venezuelan historian with a distinct interest in these religious groupings that abounded in the colony as well as in Latin American folklore. According to this historian, the church would intervene only in the naming of the cofrades, or leading members of the societies. ${ }^{102}$ The cofradías, for the most part, pe rmitted A fricans to e stablish c eremonies ba sed on $t$ heir he ritage in far-away 1 ands, in honor of their idols, utilizing the Catholic rituals. To amplify this point, Acosta Saignes wrote:

The c olonial a uthorities a llowed, s ince the s ixteenth c entury, for the s laves t $\mathrm{o}$ celebrate $\mathrm{c}$ ertain (liturgical) h olidays, even $\mathrm{p}$ ermitting th em to ta ke part in organizational and lavish parades. This was not done for the purpose of pandering to the blacks, but to facilitate the illusion that they possessed true, free will and to cultivate th $\mathrm{e} f$ eeling th at th ey $\mathrm{c}$ ould $\mathrm{p}$ erform $\mathrm{c}$ ertain a ctivities $\mathrm{u}$ nhindered. Therefore, they could ke ep their drums, along with some dances and songs that were gradually modified to c ontain onl y reminiscences of their A frican origins. Over time, however, the African words used in the various celebrations lost their spiritual me aning and significance; with mo st A fro-Venezuelans onl y cognizant that the words derived from other lands and other times, whence their ancestors were free and happy. ${ }^{103}$

The dut y of preserving what c ould be salvaged of the A frican he ritage of V enezuela's blacks and its significance fell on the leadership of the confradías. In all of the la rger cities confradías were organized. These confradías were governed by general provisions outlined in their own regulations that took into account any special circumstances of their location, church or conditions(s) of their constituents. ${ }^{104}$ Acosta Saignes believes that the diffusion of the cult of

\footnotetext{
102 Ibid., 224.

${ }^{103}$ Ibid., 215.

${ }^{104}$ Ibid.
} 
San Benito throughout the entirety of Venezuela helped to maintain a greater degree of African acculturation in the Bolivarian country. Said Acost Saignes:

In the west, San Benito was honored with the drums of the chimbángueles.... His devotees were dancing from the lowlands of the south of Lake Maracaibo to the peaks and va lleys of Mérida and Trujillo. They sang s ongs, kept promises they made ear ly, $\mathrm{p}$ layed $\mathrm{s}$ trange $\mathrm{m}$ usic $\mathrm{w}$ ith $\mathrm{t}$ he $\mathrm{n}$ ose $\mathrm{f}$ lute, a nd pe rformed 1 ong pilgrimages $\mathrm{t}$ o $\mathrm{t}$ he $\mathrm{s}$ ound of A ngolan dr ums (chimbángueles). A lso, w estern communities trembled in unison. Both free and slave sectors w ere impressed by the power of San Benito, and the scope of his influence was greatly extended. ${ }^{105}$

Because of the w ork of these s ocieties, a g ood de al of ritual ha s be en salvaged over time. The fact that s ome of this material lives on i $n$ the folk lore of the pe ople, such as that encountered in the camps and factories of working class Venezuelans, is encouraging. And by the $s$ ocieties $b$ ringing these tr aditions of the $b$ lack s aint to the ma sses, they $h$ ave especially reached and galvanized another oppressed minority in Venezuela, the Native Americans. S tates Alexi $\mathrm{P}$ eñaloza $\mathrm{T}$ orres, a $\mathrm{r}$ esearcher on $\mathrm{N}$ ative $\mathrm{A}$ merican customs a nd $\mathrm{t}$ raditions i $\mathrm{n} t$ he Venezuelan A ndean village of M ucuchíes, ${ }^{106}$ there was "one good da y, in those years of the foundation and re-foundation of the village, ${ }^{107}$ where there appeared a small statue of the Black Saint in the ruins of a house situated on the plateau of B alza." T he pe ople, upon s eeing this, became an imated to s uch an ex tent, that in the place of the s tatue's ap pearance they b uilt a chapel. B ut afterwards, they moved the black saint out of the chapel and put him in a regular church building, dedicated to "Santa Lucía de Mucuchíes," the blessed lady to whom it was San Benito's consecrated duty to forever serve as guardian and protector. ${ }^{108}$

\footnotetext{
${ }^{105}$ Ibid., 219.

106 Alexi P eñaloza T orres, Mérida: Alcaldías del Estado Mérida y Entidades Culturales (Mérida, V enezuela: Gobierno del Estado Mérida, Dirección de Cultura del Estado Mérida, 1993), 14.

${ }^{107}$ Ibid. In 1568 Mucuchíes was named by its founder, B artolomé Gil, as "San Sebastían." T his initial S panish foothold in the area was tenuous, as some rogue members of the local Timotes/Mucuchíes tribe soon pushed the Spaniards out. B ut in 1626 it was reestablished under Spanish control by Fray Bartolomé Díaz, who renamed it "Santa Lucía de Mucuchíes." It was so named because a partial structure remained of a house that once contained a small family altar dedicated to Santa Lucía.

${ }^{108}$ Balza Santiago and Rangel, "Mucuchíes honra a San Benito de Palmero," 75.
} 
Concerning the miraculous condition of the black saint, Peñaloza Torres writes about the history of a group of rogue Timotes bandits that lived only to perpetrate bad deeds against the people of Mucuchíes. He r ecounts how one da y this r enegade $\mathrm{b}$ and of $\mathrm{T}$ imotes e ntered the village and started to wreak havoc on their fellow indigenous brothers and sisters, as well as the Spanish, when all of a sudden, over a hilltop appeared a great army of defenders commanded by a s mall black man. This black commander raised a banner high over his head and the bandits fled, never to return.

Another history, also referred to by P eñaloza Torres, describes the actions taken by the Colonel of the Patriotic Army Rafael Salas, under the command of General Campo Elías, in the 1816 Campaña Admirable (Admirable Campaign), during the terrible times of the revolution in defending Mucuchíes against the Spanish imperial forces. B eing in torment over the horror of the war and the loss of good men under his command, the colonel got down on his knees before the statue of San Benito and prayed that the black saint would make a miracle happen. If the saint $\mathrm{w}$ ould a nswer hi s pr ayer, a nd $t$ urn $t$ he $t$ ide of ba ttle, $t$ he pa triot of ficer promised $t$ hat "forevermore a military tribute would be rendered to the honor of S an Benito." S uddenly, his remaining $m$ en got the up per hand in the battle and the $S$ panish were in full retreat from the Andean village. A pparently, S an Benito heard the earnest prayer of Colonel Salas, and to this present time, military h onors a re rendered not only in Mucuchíes, but in m any other parts of Venezuela and even Colombia, to the black saint on his special church day(s). ${ }^{109}$

In this same tradition, the appearance of S an Benito resuscitated the hop es of the local patriot forces that valiantly fought against the Spanish tyrants. Ever since that near mythic day, the Festival of S an Benito has be en annually celebrated in various sites throughout Venezuela

\footnotetext{
${ }^{109}$ Belis Araque de Silva, “Calendario Folklórico,” Revista Bigott 16:42 (March-June 1997): 62-63.
} 
until a ge neral a greement $w$ as reached to fix the da te on $t$ he $29^{\text {th }}$ of December of ea ch year. Colonel Salas himself de signated Raphael Albarrán as the first captain and chief of the holiday festivities. Later c ame Lucas R angel, Lucio Espinoza, David Espinoza, Ismar Quintero, A bad Antonio Espinoza, etc. From the beginning, the men who participated in these activities colored their faces black in honor of San Benito with ink obtained from mixture of soot from kerosene lamps with Vaseline and oil. T hey w ear brown uniforms. Novenas (special prayers ex tended over nine days) begin with processions from house to house, with local musical accompaniment and dancing.

Initially, the locals carried the famous chopos, colonial-style rifles no longer in common usage. T hese weapons were first donated by Colonel Salas. In the beginning, these activities were s omewhat di sorganized and e ven dangerous, as m any of the participants had no s pecial training in these weapons and some were marching with the arms under the influence of alcohol. Sometimes soldiers or spectators were burned, hurt or killed. Therefore, in 1980 the Archbishop of Mérida, Monsignor Miguel Antonio Salas, intervened with the issuance of a decree declaring the elimination of San Benito festivities on the grounds that they bordered on paganism and did not a gree $\mathrm{w}$ ith $\mathrm{C}$ atholic $\mathrm{t}$ radition i nsofar a s $\mathrm{r}$ espect in $\mathrm{t}$ he proper $\mathrm{v}$ eneration of $\mathrm{s}$ aints. $\mathrm{T}$ he devotees, then, promised that they would carry out the San Benito festivities in a more respectful and organized manner, thus avoiding any accidents with firearms. The devotees promised that if the Catholic hierarchy did not think that the San Benito festivities went well, they would respect the decree of the Archbishop to abolish said festivities forevermore. ${ }^{110}$

${ }^{110}$ Balza Santiago and Rangel, "Mucuchíes honra a San Benito de Palmero,” 79. 


\section{Other Venezuelan Religious Syncretism}

In Venezuela, other African-European-Indigenous belief systems to consider are the cults of the Black Panther Woman, Maria Lionza, and San Juan Bautista. Like the veneration of San Benito, the activities s urrounding these other forms of s yncretism have become more profane over time, and their diffusion has become just as wide. But there are some differences. The centers of focus $\mathrm{f}$ or $\mathrm{t}$ hese va ried $\mathrm{r}$ eligious $\mathrm{m}$ odalities $\mathrm{f}$ all $\mathrm{i} \mathrm{n}$ di stinct $\mathrm{g}$ eographic areas of Venezuela apart from Zulia state. A lso, the degree to which indigenous groups have impacted these structures is significantly higher than the case of San Benito, where the A frican influence was the stronger one, overpowering the indigenous.

The first of the African-European-Indigenous cults to be examined is that of the Black Panther W oman, cal led La Pantera Negra by th e $\mathrm{r}$ esidents o f th e village of A ripao in Venezuela's Bolívar S tate. A ripao w as e stablished dur ing colonial t imes b y r unaway s laves (maroons) and local indigenous people. T oday there are only $300 \mathrm{i}$ nhabitants in the village. $^{111}$

Based on e xtensive interviews with them, a composite account of their origins and that of the

Black Panther Woman was put together by anthropological researcher Berta Pérez:

A couple from the Spanish Crown had a daughter who fell in love with a black slave and became pregnant. They were afraid of being reprimanded for making the European bl ood i mpure, s o they fled with all their pe ople and c ame to the Caura River where they founded Corocito. T he couple had a mulata baby girl, who $\mathrm{w}$ as know $\mathrm{n}$ a $\mathrm{s} \mathrm{P}$ antera $\mathrm{N}$ egra. $\mathrm{S}$ he w as $\mathrm{r}$ aised $\mathrm{t}$ here a nd be came ve ry powerful. When she grew up, the Queen Pantera Negra was very beautiful. The old pe ople us ed to s ay that she attracted a lot of men, who w ould fight for her. She us ed he $\mathrm{r} f$ eminine qua lities $\mathrm{t}$ o e ntice a nd e nchant $\mathrm{m}$ en. $\mathrm{B}$ ut $\mathrm{s}$ he a lso mercilessly killed a nyone w ho c rossed he $\mathrm{r}$ or w ho s he did not like. S he w as always armed. S he did atrocious things, and that is why she was called Pantera Negra. She was evil. The Spaniards killed her mother and Pantera Negra wanted to take revenge. S he be came evil for her hatred a gainst the S paniards. S he.... had he $\mathrm{r}$ ow $\mathrm{n}$ ki ngdom with bl acks a nd i ndigenous $\mathrm{s}$ laves. $\mathrm{S}$ he $\mathrm{w}$ as $\mathrm{t}$ he $\mathrm{r}$ uler (cacica) a nd richest w oman in the C aura region. S he ha di amonds and gold.

\footnotetext{
${ }^{111}$ Berta Pérez, "Pantera Negra," in Arlene Torres and Norman E. Whitten, editors, Blackness in Latin America and the Caribbean, V. I (Bloomington: Indiana University Press, 1998), 225, 227.
} 
Pantera Negra was a loner who lived in an underground hut in Barrancas across from Corocito, her colony. She us ed to come out, through a tunnel, to ba the in her river pond, known as Castillo de Piedras...."112

Of interest, locals still keep a distance from both the alleged locations of her bathing pool and dw elling. ${ }^{113}$ The $\mathrm{B}$ lack $\mathrm{P}$ anther $\mathrm{W}$ oman i s be lieved $\mathrm{t}$ o ha ve a ppeared on num erous occasions. This i s es pecially the $\mathrm{c}$ ase when the d escendants of $\mathrm{h}$ er co lony are m enaced by outside $\mathrm{f}$ orces, $\mathrm{f}$ or $\mathrm{s}$ he must de fend he $\mathrm{r}$ pe ople a nd $\mathrm{r}$ epel $\mathrm{t}$ he $\mathrm{i}$ nvaders. In $\mathrm{f}$ act, dur ing the Venezuelan war for independence and afterwards, the legend of the Black Panther Woman took on added significance as the patriotic forces could appeal to her in seeking the aid of both blacks and indigenous people in the Caura River basin and its environs, enlisting them in fight against Spanish rule. She continues to be both a culturally hi storic and s ymbolic force, providing a continuity that transcends time and space via the importance, potency and power imputed to her. The $\mathrm{c}$ ontinued e xistence of the A ripaeños in the e xtensive B olívar S tate c ould, i $\mathrm{n}$ i tself, be construed as "proof of the living legacy of La Pantera Negra."114

Another pow erful $\mathrm{f}$ emale $\mathrm{f}$ igure i $\mathrm{nt}$ he $\mathrm{m}$ ythology o $\mathrm{fV}$ enezuela, e ncompassing multicultural A frican-European and Indigenous l egacy, is that of M aría Lionza. T he cult of María Lionza is focused on a woman who can assume two forms. When appearing as a Native American, she is pow erful and s exy. S he is nude and $\mathrm{r}$ iding a tapir, and hol ds be tween he $\mathrm{r}$ outstretched hands a human pelvis. In this guise, she is sometimes known as "Yara," which is purported to be her authentic indigenous name. She can also morph into the form of a young,

\footnotetext{
112 Ibid., 224.

${ }^{113}$ Ibid., 235.

${ }^{114}$ Ibid., 240.
} 
white virgin. In this guise, she is known as "María" and wears a blue mantle over her head and shoulders, bearing a striking resemblance to the Virgin Mary. ${ }^{115}$

This $\mathrm{r}$ emarkable w oman $\mathrm{r}$ eigns ov er a ki ngdom of s pirits dw elling i $\mathrm{n}$ the $\mathrm{h}$ eart of Venezuela. The mountain of S orte is only a six hour drive from Caracas, in the María Lionza National Park. Most of the pilgrims who flock to her mountain home on weekends and holidays are from the low and middle classes, urban Venezuelans. F or the most part, they are mestizos who consider the mountain to be an "autochthonous sacred place.",116

The spirits who dwell in Queen María Lionza's realm are historic and legendary figures from V enezuelan hi story. T hey i nclude "El Libertador" ( the lib erator S imón B olívar); "El Negro F elipe," a n A frican w ho i s s aid t o ha ve f ought a t B olívar's s ide i n t he W ar f or Independence; “ El Indio G uaicaipuro," w ho f ought a gainst t he c onquistadores; a nd J osé Gregorio H ernandez, a popul ar a nd m uch-loved V enezuelan doc tor w ho i s c urrently b eing considered $\mathrm{b}$ y t he $\mathrm{C}$ atholic $\mathrm{C}$ hurch for s ainthood. $\mathrm{T}$ hese a nd ot her s pirits, i ncluding Lionza herself, are intimately associated with the protection and advancement of a free and multicultural Venezuelan republic, and frequently possess the bodies of various mediums known as materias. Those m ediums who on ly channel messages from the spirits but who c annot be pos sessed by them a re know $\mathrm{n}$ as bancos. Th e bancos work $\mathrm{w}$ ith the materias in making the s pirits feel comfortable in their temporary bodi es, and a lso in interpreting the $m$ essages $p$ assed from the spirits to the audience. Such interactions between humans and spirits usually take place at night, and the indwelling of the spirits is accomplished to the incessant beating of African drums. ${ }^{117}$

\footnotetext{
115 Barbara Placido, "An Analysis of Spirit Possession in the Venezuelan Cult of María Lionza," Journal of the Royal Anthropological Institute 7:2 (June 2001): 210.

${ }^{116}$ Ibid., 211.

${ }^{117}$ Ibid.
} 
When María Lionza appears as a white virgin, accompanied by E1 Negro Felipe and El Indio G auicaipuro, they a re referred to a s "Las Tres Potencias" ( $\mathrm{t}$ he $\mathrm{T}$ hree $\mathrm{P}$ owers). $\mathrm{T}$ hey collectively become an emblem of the Venezuelan nation and its people. Those participating in the cult of María Lionza understand the words imparted to them from the spirits a s critical to Venezuela's future a nd s tatus. T hose pos sessed or hi ghly involved in the $\mathrm{cult}$ a ppear to be engaged in an ongoing dialogue with anthropologists, historians, the media and the state. ${ }^{118}$

An ex cellent ex ample of $t$ he $p$ ower $t$ hat $M$ aría Lionza $h$ as o ver $h$ er $f$ ollowers $w$ as demonstrated in Caracas after humidity and corrosion weakened a statue of the goddess situated in a city park, causing her to lean backward from her mount on $t$ he tapir. M argot Tejada, an alleged materia for the goddess, claimed that the damage affected on the statue meant that María Lionza herself suffered the wound on behalf of her people. María Lionza was absorbing all the negative energies surrounding Caracas so the pe ople themselves would not be hurt in riots and civil unrest. Many of her devotees participated in day and night vigils around the cordoned-off statue, $\mathrm{c}$ arrying $\mathrm{w}$ hite $\mathrm{c}$ andles a nd $\mathrm{g}$ ifts to $\mathrm{d}$ eposit $\mathrm{at} \mathrm{t}$ its $\mathrm{b}$ ase, $\mathrm{u}$ ntil $\mathrm{s}$ uch a time $\mathrm{a} \mathrm{s}$ it $\mathrm{w}$ as completely restored. ${ }^{119}$ A French-Yoruba medium in Caracas also claimed to receive messages from María Lionza, $\mathrm{s}$ tating that "her s pirit had flown to the $\mathrm{S}$ acred Isle of the Orisha in the Caribbean $t \mathrm{o} c$ onsult $\mathrm{w}$ ith $\mathrm{t}$ he $\mathrm{H}$ igh $\mathrm{C}$ ouncil of $\mathrm{B}$ abalawo and $\mathrm{r}$ eceive pow ers $\mathrm{t} o$ he $\mathrm{lp} t$ he Venezuelans overcome evil in their midst," and that she would return only after the statue was repaired. ${ }^{120}$ These and ot her pur ported r evelations received full c overage in El Nacional and other major Venezuelan newspapers.

The next Venezuelan spiritual cult is that of San Juan. Like San Benito, but unlike the Black Panther Woman and María Lionza, San Juan is a legitimate Catholic saint (Saint John the

\footnotetext{
${ }^{118}$ Ibid., 208.

${ }^{119}$ Garnica, "Humedad y corrosión," El Nacional (Caracas), 7 June 2004.

${ }^{120}$ Luis Chumaceiro, "La venganza de la reina," El Nacional (Caracas), 9 June 2004.
} 
Baptist). But while San Benito is celebrated during the W inter Solstice, San Juan is celebrated during the Summer Solstice. Most likely, San Juan replaced Janus Bifrons as the protagonist of Summer S olstice c elebrations n ot lo ng a fter the $\mathrm{v}$ ast ma jority of R omans ha $\mathrm{d}$ c onverted to Christianity. ${ }^{121}$ As the Summer Solstice corresponds to the arrival of rains and hence the most important time of the agricultural calendar in the same latitudes that pass through the northern tier of $\mathrm{S}$ outh $\mathrm{A}$ merica a nd $\mathrm{t}$ he $\mathrm{t}$ ropical $\mathrm{r}$ egions i $\mathrm{n}$ a nd a round $\mathrm{t}$ he $\mathrm{B}$ ight of $\mathrm{B}$ enin, one $\mathrm{c}$ an understand how San Juan became associated with fertility and good harvests. So in San Juan we see not only an African and New World syncretism, but also one illustrative of religious mixing between pagans and Christians in the old Roman Empire.

San J uan i s al so cel ebrated t hroughout V enezuela i $\mathrm{n} \mathrm{a} \mathrm{v}$ enue o ff ire an $\mathrm{d} w$ ater, reminiscent of the religious observances carried out by some West African peoples. ${ }^{122}$ The saint is treated like a fetish, b athed and ne atly dressed, be fore going to battle against $\mathrm{S}$ atan and his minions. Like San Benito, he is carried through Venezuelans towns in processions, accompanied to the music of African drums and revelry. His festivities begin on June 23 and usually last for three or four days. S an Juan passes from the procession to spend the nights in the hom es of leading m embers of his confradía. F or the m ost part, S an Juan c elebrations take place in the more populous central coastal regions of Venezuela. The most notable events in his honor are held in Aragua, Barlovento and Carabobo, and attract visitors from all over Venezuela, if not the world. Some lament the degeneration of the San Juan celebrations, and those surrounding other spiritual figures as well, into more profane assemblies. ${ }^{123}$ The gatherings are now largely viewed as excuses for people to dance, drink and party. Whether or not this trend can be halted, or even reversed, remains to be seen.

\footnotetext{
${ }^{121}$ Juan Liscano, La fiesta de San Juan el Bautista (Caracas: Monte Avila Editorial, 1973), 46.

122 Ibid.

${ }^{123}$ Angelina Pollak-Eltz, La negritud en Venezuela (Caracas: Lagoven, 1992), 62.
} 


\section{Conclusions}

What can be g leaned from a s tudy of how A fricans a nd A frican de rived pe oples pa y homage to their deities is that, in either case, the orishas are not that distant from their devotees. A santero, or devotee of an orisha/saint, can interpret the will of the deity through divination. He or she can allow the orisha to possess their body and mind. In this way, the orisha can voice their $\mathrm{c}$ ounsel to the de votee. Followers $\mathrm{m}$ ay a lso pe tition a $\mathrm{n}$ orisha through prayers, $\mathrm{m}$ usic, proper behavior and offerings, much as a Catholic can appeal to a saint. ${ }^{124}$ Understanding this difference b etween $\mathrm{C}$ atholicism and the $\mathrm{Y}$ oruba-derived religions is crucial to the theology of San B enito, f or hi s de votees a ttain a hi gh 1 evel of s piritual a wareness t hat i s f requently interpreted as pagan. For this reason, the Catholic Church has not given its imprimatur to any of the $\mathrm{f}$ estivities $\mathrm{t}$ hat $\mathrm{h}$ ave bl ossomed a round $\mathrm{S}$ an $\mathrm{B}$ enito ove $\mathrm{r} t$ he centuries, e ven $\mathrm{t}$ hough it recognizes the legitimacy of his sainthood. ${ }^{125}$

In this chapter a brief survey of Kongo and Imbangala belief systems was also presented. Linkages of $t$ hese $\mathrm{s}$ ystems t $\mathrm{o} \mathrm{Y}$ oruba $\mathrm{r}$ eligious $\mathrm{t}$ raditions $\mathrm{w}$ ere hi ghlighted. It $\mathrm{w}$ as $\mathrm{f}$ urther demonstrated how va rious s ystems of s yncretism e merged in s undry parts of the New W orld. One such syncretism that came forth in Venezuela was the fusion of the African orisha Ajé with the $\mathrm{C}$ atholic $\mathrm{S}$ an $\mathrm{B}$ enito. $\mathrm{T}$ he a lleged or igins of bot $\mathrm{h}$ of $\mathrm{t}$ hese s piritual pe rsonages $\mathrm{w}$ ere explored, $\mathrm{r}$ espectively, along $\mathrm{w}$ ith $\mathrm{t}$ heir hi storical s ignificance $\mathrm{t} \mathrm{o} \mathrm{V}$ enezuelan hi story. $\mathrm{T}$ his included a e ncapsulation of the $\mathrm{c}$ ultural e vents and festivities acco mpanying the $\mathrm{h}$ omage to these important figures.

It is not difficult to understand how an adoration of Ajé and San Benito became fused in the Sur del Lago Maracaibo. Most importantly, of all the saints in the Roman Catholic pantheon,

\footnotetext{
124 "The Lure of Santeria," Awake!

${ }^{125}$ Balza Santiago, "Mucuchíes honra a San Benito," 79.
} 
San B enito w as black. $\mathrm{H}$ is m ere presence in s uch a $\mathrm{n}$ a ugust forum of white, hi storical, and spiritual stalwarts, allowed both San Benito's African and New World devotees to create, define and name their own religious structures, that in Venezuela is generally referred to as "La Cultura San Benitera" ( San Benito C ulture). M aulana Karenga, the bl ack na tionalist from California who i ntroduced Kwanzaa as a $\mathrm{n}$ a lternative to the gross ma terialism th at $\mathrm{c}$ haracterizes the American approach to the Christmas holiday s eason, w ould most likely de fine the a doption of San B enito b y the S ur del Lago A fricans and African-derived p eoples as a clear ex ample of Kujichagulia, or s elf-determination. ${ }^{126}$ Kujichagulia, the s econd pr inciple of Nguzo Saba, ${ }^{127}$ asserts that Africans have the right to speak for themselves, and therefore should speak on their own behalf, rather than allowing others to speak for them. In the case of blacks in the Sur del Lago, $t$ he ve neration of $S$ an Benito ha s pe rmitted $t$ hem $t o$ recover 1 ost hi storic a nd $r$ acial memories that they can employ as a basis for the reshaping of the world in their own image and interests. They $\mathrm{c}$ an thereby speak their ow $\mathrm{n}$ s pecial religious truth to pow er and $\mathrm{r}$ aise images above the Earth that reflect their capacity for human greatness and progress. Karenga has stated:

The $\mathrm{p}$ rinciple and $\mathrm{p}$ ractice o $\mathrm{f} \mathrm{s}$ elf-determination $\mathrm{c}$ arries within th em the assumption that we have both the right and responsibility to exist as a people and make our own unique contribution to the forward flow of human history.... So it reminds $u$ s o $\mathrm{ft}$ he $\mathrm{f}$ act $\mathrm{t}$ hat $\mathrm{A}$ frican $\mathrm{p}$ eople cr eated an $\mathrm{d} i$ ntroduced $\mathrm{t}$ he $\mathrm{b}$ asic disciplines of human knowledge- science, technology, geometry, math, medicine, ethics, advanced architecture, etc. And it urges us as a people not to surrender our historical and cultural i dentity to fit into the $\mathrm{c}$ ulture of another. O penness $\mathrm{to}$

\footnotetext{
126 Maulana Karenga, "From the Nguzo Saba (The Seven Principles): Their Meaning and Message," (1988), in Modern Black Nationalism: From Marcus Garvey to Louis Farrakhan, ed. W illiam L. Van Deburg (New York: New York University Press, 1997), 279.

${ }^{127}$ Ibid., 276. Nguzo Saba was developed and offered by Karenga as an Afrocentric value system which would serve the interests and aspirations of African-derived peoples of the diaspora by organizing and enriching relations with $b$ lack p eople o $\mathrm{b}$ oth the personal a nd $\mathrm{c}$ ommunity le vel. This system a lso a ttempts to e stablish s tandards, commitments and priorities that enhance the human possibilities of blacks, both individually and collectively; aid in the recovery and reconstruction of lost memories and cultural, Afrocentric paradigms; contribute to a communitarian core system of ethical values, es pecially for children; and assist in the formulation of a new black persona for the new millennium and beyond.
} 
exchange is a given, but it presupposes that one has kept enough of one's culture to engage in exchange, rather than slavishly follow another's lead. ${ }^{128}$

In the Sur del Lago, one need not travel far to find evidence of such an African cultural legacy, referred to by Karenga. The adhesion of the music of the Chimbangaleros to the $\mathrm{S}$ an Benito festivities in the to wns and villages of the Sur del Lago a re c learly of A frican ${ }^{129}$ and, specifically, I mbangala o rigin. ${ }^{130}$ The multiple dr um rhythms for $\mathrm{S}$ an Benito a re much more pronounced than those for any other saint celebrated in Venezuela. The songs in honor of the black saint are sung in a chorus or solo, and the dances are frenetic. Almost all the singers shake maracas to the beat of the chimbangueles, and in some villages they blow whistles, or pitos, as they march in procession. ${ }^{131}$

Within $\mathrm{V}$ enezuela, $\mathrm{t}$ he s laves a rrived $\mathrm{f}$ rom $\mathrm{m}$ any di fferent $\mathrm{r}$ egions of $\mathrm{A}$ frica. $\mathrm{T}$ his diversity is reflected in the great variety of drums that can be seen in both religious and secular celebrations. B ut be cause the enslaved Africans c ould not br ing their own instruments from Africa, they had to create new ones after their arrival in Venezuela. Sometimes they even had to construct them out of different materials than those they worked with in A frica. N evertheless, the e thnic or igin of $\mathrm{m}$ ost $\mathrm{A}$ frican $\mathrm{d}$ rums a nd ot her $\mathrm{m}$ usical i nstruments $\mathrm{c}$ an be a ccurately determined by their design, sound, and proper names, much like Martínez did in determining the Imbangala roots of the chimbangueles.

It also $\mathrm{c}$ ame to light that Juan de Chourio w as a de votee of the V irgin Mary bent on spreading the virtues of Roman Catholicism and western civilization to the farthest reaches of the then known world. And due to the propagation efforts of the Capuchin Fathers both in Angola and Venezuela, Chourio may have been influenced by them in making the decision to bring some

\footnotetext{
${ }^{128}$ Ibid., 280.

${ }^{129}$ Pollak-Eltz, La negritud, 36.

${ }^{130}$ Martínez, Como Bailar, 5.

${ }^{131}$ Pollak-Elts, La negritud, 38.
} 
of the Imbangala with him to the Sur del Lago region. In the remaining chapters, the fate of the Sur del Lago blacks in the pageant of Afro-Venezuelan history will be revealed, in both the context of resistance to enslavement and the legacy of racism in Venezuela. 


\section{CHAPTER FIVE}

\section{RESISTANCE AND SURVIVAL}

\section{Introduction}

The $\mathrm{s}$ urvival o $\mathrm{ft}$ he A fro-Zulians $\mathrm{w}$ as contingent upon $\mathrm{t}$ he $\mathrm{w}$ ay $\mathrm{t}$ hat $\mathrm{t}$ hey de fined themselves as a community in relation to the larger Venezuelan and trans-Atlantic s ociety, of which they were unquestionably a part. When the Afro-Zulians attempted to survive with their Imbangala-Angolan c ulture intact, this w as de pendent upon their be ing able to s trike a subtle balance between not allowing themselves to be wholly absorbed by and integrated into the larger Venezuelan and Eurocentric trans-Atlantic society on one hand, and not permitting themselves to be totally isolated from in it on the other hand. This is to say that the Afro-Zulians consistently found themselves walking a tight rope between integration and isolation.

Probably m ore s o than other A fro-Venezuelans, C hourio's A fro-Zulians w ere ab le t o hold on, s urvive and flourish because they developed and enhanced a hi storical consciousness that dated back to a time before colonization and conquest. Thus, while the Afro-Zulian identity can be seen in the context of a cu lture based on m ore than just struggle and resistance, there is little doubt that these two elements were key factors in its preservation and perpetuation.

This chapter will also attempt to demonstrate that the history of the Sur del Lago belongs to the Afro-Zulians. Their presence in this area, like the presence of other Africans and Africanderived peoples throughout Venezuela, contributed to both the rise and fall of Spanish dominion in the northern tier of South America. Ultimately, however, this served to significantly alter the balance of pow er in the trans-Atlantic w orld, whence it s hifted from the colonizers to ne wly independent A merican republics. T his chapter, therefore, places the struggle and resistance of the Afro-Zulians within a context of the trans-Atlantic world. 
While the A fro-Zulians, like other pe oples of A frican descent in the A mericas, c an be seen a s obj ects of oppr essive s ocial, pol itical a nd e conomic s tructures, a m ore c omplete panorama emerges $w$ ith a n a cquired unde rstanding of this population as subjects of their ow $n$ history. T he Afro-Zulians, in this framework, were not the mere pawns of the e conomic and political situation in which they once found themselves. Rather, the Afro-Zulians are products of the interaction between these conditions and efforts to develop their own sense of what they are and what they want to be. They negotiate life, and history, in their own ways. They live life as they transform it.

The Afro-Zulians devised their own mechanisms of resistance and survival. This chapter will examine some of these, especially their ideological tools and social networks that served as vehicles of struggle over time and space. For the A fro-Zulians, their culture can be defined as the dynamic synthesis of their experiential knowledge, beliefs, values and norms that express and have their de rivation from the conflicts encountered at e ach s tage of their de velopment in the search for s urvival and progress. ${ }^{1}$ In this ch apter, therefore, the fate of Chourio's Imbangala party and their Afro-Zulian descendents in the Sur del Lago will be examined, up to the end of the eighteenth century and the start of Venezuela's struggle for independence from Spain, and all within the historical context of the a forementioned cultural criteria for struggle, resistance and survival.

In general terms, the struggle of blacks in Venezuelan colonial society can be interpreted as a manifestation of the $\mathrm{c}$ ontradictions i nherent in a colonial $\mathrm{s}$ ystem that $\mathrm{pl}$ aced at odds the interests of a mostly white landowning class and a manual labor force, largely enslaved. For the most part, V enezuelan hi storians of the European pos itivist s chool, led by A rturo U slar P ietri since 1937, have created a false impression that some slaves, representing but a small fraction of

\footnotetext{
${ }^{1}$ Amilcar Cabral, Selected Speeches (New York: Monthly Review Press, 1973), 39-56.
} 
the overall mass of blacks in the colonial Venezuelan population, rose up sporadically and only as a $\mathrm{r}$ eaction $\mathrm{t} \mathrm{o}$ ha rsh pe nalties a nd $\mathrm{c}$ ruel puni shments i mposed on $\mathrm{t}$ hem $\mathrm{b}$ y $\mathrm{t}$ heir $\mathrm{s}$ o-called "masters." U slar P ietri a nd o ther p ositivists $\mathrm{r}$ educed A frica's c ontributions t o V enezuelan history m ainly to dr ums and "witchcraft." If the pos itivists ha d their way, the bl ack r acial strains in Venezuelan society would be greatly diluted. A ccording to Uslar Pietri, "This means that if we cannot s ubstantially m odify the e thnic c omposition of our popul ation, it $\mathrm{w}$ ill be virtually imp ossible t o c hange the c ourse of o ur hi story and to make our c ountry a m odern nation." 3

By i mposing t hese $\mathrm{E}$ urocentric, he gemonic $\mathrm{p}$ ositions ont $\mathrm{o} \mathrm{V}$ enezuela's hi storical discourse a nd c ompulsory s chool c urricula, a 11 A fro-Venezuelans w ere negatively i mpacted. These E urocentric pos itivist hi storians ha ve failed t $\mathrm{o} t$ ake i nto a ccount the bi gger pi cture of blacks, bot $\mathrm{h}$ free and enslaved, forming s trategic a lliances $\mathrm{w}$ ith ot her factions of the colonial Venezuelan s ociety for the pur pose of e ither s ubverting or ove rthrowing i t. T herefore, a $\mathrm{n}$ Afrocentric perspective is imp ortant, because its infusion will help a meliorate this situation by providing $\mathrm{f}$ or a de construction of E urocentrism, a nd $t$ hus pe rmitting A fro-Zulians t o s ee themselves as agents of their own destiny.

By bl acks fleeing $\mathrm{i}$ nto the i nterior a nd $\mathrm{j}$ oining $\mathrm{w}$ ith $\mathrm{N}$ ative $\mathrm{A}$ merican pe oples, ne w, alternate an $\mathrm{d} v$ iable s ocio-economic $\mathrm{c}$ ommunities (cumbes) were established. $\mathrm{T}$ hese $\mathrm{w}$ ere located far from the control and influence of the domineering white, Spanish society; and those

\footnotetext{
2 Jesus G arcia, “ Demystifying Africa's Absence i n V enezuelan H istory a nd C ulture" ( $15 \mathrm{~J}$ anuary 2 004), www.venezuelanalysis.com, accessed 19 A ugust 2004, quotes Uslar Pietri paper, "Identidad nacional," presented at a meeting of the Grupo Santa Lucia in August 1983.

${ }^{3}$ Arturo Uslar Pietri, El país necesita inmigración (Caracas: Boletín de laCámara de Comercio de Caracas, February 1937) 235. Uslar Pietri (1906-2001) was the winner of many prizes in history, and his influence continues to exert itself in V enezuela's history acad emy. H e s erved o $\mathrm{n}$ the $\mathrm{p}$ restigious a nd co nservative $\mathrm{P}$ olar F oundation as a $\mathrm{n}$ executive consultant on the council responsible for the publication of the four-volume, 1,076 pages, Diccionario de Historia de Venezuela, and chaired the Political Sciences department at La Universidad Central de Venezuela in Caracas.
} 
who remained in the more populated coastal areas took advantage of every opportunity to learn about $\mathrm{r}$ esistance $\mathrm{i} \mathrm{n}$ o ther ar eas o $\mathrm{ft}$ he $\mathrm{N}$ ew $\mathrm{W}$ orld as $\mathrm{w}$ ell as $\mathrm{m}$ onumental $\mathrm{s}$ ocio-political movements emerging in France and the British American colonies. Armed with this information, Venezuelan blacks joined with Creoles in both planning and carrying out acts of insurrection and rebellion $\mathrm{w}$ ith $\mathrm{t}$ he pur pose of a bolishing s lavery a nd $\mathrm{t}$ ransforming $\mathrm{t}$ he $\mathrm{n}$ orthern $\mathrm{t}$ ier of $\mathrm{S}$ outh America into a free and independent republic based on liberal ideals.

Therefore, the last section of this chapter dealing with the abolitionist and anti-colonial, Haitian-inspired movement of José Leonardo Chirino, will attempt to show that conspiracies and rebellions of the Venezuelan blacks had, from the start, the objective of the abolition of slavery and the near to tal transformation of colonial society. T his is historically important because it raises the pe rception of the bl ack insurrections from m ere p rotest reactions to that of a w ell organized and orchestrated pol itical and social movement. T he blacks of V enezuelan colonial society a re historically vindicated through this process. A cting as agents of their ow $\mathrm{n}$ destiny, the A fricans a nd African-derived $\mathrm{p}$ eoples of colonial $\mathrm{V}$ enezuela $\mathrm{c}$ arried out $\mathrm{r}$ ebellions a nd uprisings $\mathrm{c}$ onditioned $\mathrm{b}$ y their class s tructure and e conomic $\mathrm{c}$ ircumstances, a s w ell a s their ideological de velopment a nd formation. I $\mathrm{n}$ ot her $\mathrm{w}$ ords, the bl acks in c olonial V enezuelan society did not hesitate to take whatever actions their leaders deemed appropriate to secure their economic and political in terests. $\mathrm{T}$ he A fro-Venezuelans $w$ ere quite $\mathrm{p}$ ragmatic. When it $\mathrm{w}$ as convenient for them to serve the Spanish Empire, they would. But they always kept their gaze fixed on the star that led to freedom, and they would turn on the S paniards if s o doing could speed the day of their liberation.

Certainly, the typical Spaniard worried little about the plight of black slaves in the New World; and by the mid-eighteenth century, there was no pretense among the Spaniards in Europe 
or the Americas that their vast colonial empire existed for any other purpose than enriching the mother country. The Spanish Crown decreed policies seeking to control all of the trade to and from its American and Caribbean colonies. And while thanks to the promptings of the Roman Catholic Church, the enslavement of Native Americans had been abolished by royal decree, they actually remained in virtual bondage to an onerous system of peonage that kept them indebted to the owners of the big estates. ${ }^{4}$

Africans fared little better, with the majority in the Americas and Caribbean suffering under the yoke of enslavement. A lthough both the Native American and African populations in the New World $w$ ere treated with a barbaric cruelty, th ey were $n$ ot $w$ ithout me ans in challenging the established order. By the end of this chapter, it is hoped that some of the questions pertaining to the $\mathrm{h}$ istory of $\mathrm{r}$ esistance in the $\mathrm{c}$ ultural, p olitical and milita ry s pheres of the A fro-descendent peoples in western Venezuela will be answered. This would include the descendants of those Africans brought to the Sur del Lago region by Juan de Chourio, swept up in the tide of new and revolutionary ideas that would ultimately usher in an end to slavery and the general acceptance of more liberal ideas among all Venezuelan and Latin American peoples. ${ }^{5}$

\section{The Afro-Zulians, 1723-1757}

The Afro-Zulians swung between initial attempts at integration (1723-1757), and seeking to is olate themselves from an oppressive and increasingly anachronistic colonial regime (17581811). This section examines the Afro-Zulian assimilation into colonial Venezuelan society. As noted in various royal orders, Chourio's blacks actually served as compatriots in the conquest of the $\mathrm{M}$ otilones. $\mathrm{T}$ his may not ne cessarily be $\mathrm{s}$ een a s $\mathrm{s}$ omething out of $\mathrm{t}$ he or dinary. It is estimated that roughly fifty years after the first landing of Columbus in the New World, Africans

\footnotetext{
${ }^{4}$ Gerard Helferich, Humboldt's Cosmos: Alexander von Humboldt and the Latin American Journey That Changed the Way We See the World (New York: Gotham, 2004), 20.

${ }^{5}$ Ibid., 21.
} 
serving as gun bearers, soldiers and scouts had been deployed to all of the areas under Spanish control, a nd us ually appearing s imultaneously with $\mathrm{t}$ he Iberian $\mathrm{c}$ onqueror. Indeed, $\mathrm{m}$ any Africans in S panish c olonial A merica had garnered fame and fortune for themselves, but "no matter how important he (the African) might become, there was always a Spaniard ready, willing and able to put him in his place." of the Africans he brought over to the Sur del Lago. However, from the Africans' arrival in 1723 until Chourio's death in 1757, they were certainly granted an unprecedented amount of de-facto and lateral freedom within the confines of Chourio's domains in the Sur del Lago, albeit more out of a pragmatic m otivation on $t$ he pa rt of the $\mathrm{B}$ asque $\mathrm{c}$ aptain a nd $\mathrm{t}$ rader rather $\mathrm{t}$ han an $\mathrm{y}$ altruistic feelings Chourio felt about the welfare and ultimate fate of his black contingent.

Because $\mathrm{C}$ hourio $\mathrm{f}$ ailed $\mathrm{t} \mathrm{o}$ be stow $\mathrm{f}$ reedom ou tright on a ny of $\mathrm{t}$ he $600 \mathrm{~A}$ fricans $\mathrm{h} \mathrm{e}$ transported to the shores of Venezuela, in retrospect it appears as though his a pproach to the Italian Capuchin fathers in Angola was less inspired by a de sire to s pread Catholicism a mong Native A mericans in Venezuela th an u sing the c lerics to help him garner an African military contingent sufficient to counter the power of the Motilones in the Sur del Lago region that were blocking his life's dream of establishing a fruitful cacao colony in the Province of Maracaibo. Although he failed in his lifetime to pacify all of the insurgent Motilones in the region, he did manage to accomplish at least some of the task, and that which went undone was assigned to his son-in-law and others.

From the following or der of di sposition, it $\mathrm{c}$ an be a scertained $\mathrm{t}$ hat $\mathrm{C}$ aptain $\mathrm{C}$ hourio's property, including control of the A fricans, went to Manuel García P eña, as h is su ccessor, to continue the work. Juan de Chourio passed away quietly in his sleep at the ripe old age of 81 , on

\footnotetext{
${ }^{6}$ Rout, Jr., African Experience in Spanish America, 77.
} 
5 November 1757, at his home in Perijá. García Peña, besides being Juan de Chourio’s son-in-

law, had also been his Creole business associate and liaison with the Spanish colonial authorities.

Don Francisco de Ugarte to Don José de Solis Folch of Cardona.

Hereby I give account of those events surrounding the death of Don Juan Chourio and the duties that he had accomplished insofar as the inventory and securing of his goods as an obligation to the royal treasury (customs house) as a consequence of the work he be gan in pacifying and populating the area of Perija, Maracaibo, the $28^{\text {th }}$ of November 1757.

Most Excellent Sir.

Sir:

Having died this same Don Juan Chourio the $5^{\text {th }}$ day of the current month, leaving a $n$ e nclosed po wer of a ttorney to testify and de claring a s his he ir D on Manuel Garcia de la Pena; and in the case that he is not found to be within the requisites to receive this inheritance, it shall be given to Doctor Don Pedro Joseph de Leyba, as one b eing empowered to a ccompany $\mathrm{C}$ rown o fficials to make a $\mathrm{n}$ inventory of the goods that have be en found pertaining to Don J uan Chourio in this city, and carrying out this dut y under the supervision of the royal treasury (customs house) to be held on the $11^{\text {th }}$ day of the following month, in which it is agreed keeping in remembrance the contract... (broken) of May 1722. T his was made with H is Royal Majesty (of S pain) to pacify and populate the territory of Perijá, e stablishing there a vi llage of at 1 east on e hundred i nhabitants within a period of four years.

These $s$ ettlers $s$ hould $m$ anifest $g$ ood qua lities a nd $c$ onform $t$ ot he conditions stated in the contract. A s this endeavor was financed in the sum of twenty thousand pe sos by the r oyal t reasury, r esulting from the $m$ ortgaging of those cac ao plantations e xtant i $\mathrm{n} t$ he $\mathrm{V}$ alle de $\mathrm{S}$ anta $\mathrm{M}$ aria, along $\mathrm{w}$ ith one hundred slaves (both sexes), an inventory and inspection of the established village and its fortifications would satisfy this government.

It was conceded to him (Don Juan Chourio)... (broken) six slave ships of up to one hundr ed t ons for this por $t$, f ree of all dut ies (entry a nd exit). T his equally applies to Cádiz (Spain) and this port (Maracaibo). This included several extensions given be cause of the pacification e ffort and conditions of $w$ ar. O ne extension, for six months, was made by the real cédula (royal order) of the $11^{\text {th }}$ day of September 1743. It was made in the hope that conditions of peace would prevail before the conclusion of the extended contract. Unfortunately, as peace has not yet arrived in the region, in this port of Maracaibo be it known that the extension of $1743 \mathrm{w}$ as still in effect, and yet another extension was made on the $22^{\text {nd }}$ day of January 1750 that was supposed to be for another six months, yet did not end until the $22^{\text {nd }}$ day of July 1752 . In view of this, on the $14^{\text {th }}$ of July of next year, based on what was ordered by the king, a military protective unit would be 
placed around the Capuchin Fathers, missionaries in the area of Perija to its native inhabitants. T his mil itary escort is to be paid from the properties of the same Chourio, and if these do not garner sufficient funds, from his private account with the royal treasury house.

On the other hand, on the $26^{\text {th }}$ of January of this same year, a detachment of $t$ wo guards was o rdered $t o$ complete $t$ he $r$ equirement of de fending the aforementioned missionaries. T hus, the reason for reimbursing the value of the property of D on Juan C hourio rests in the cost of this venture. In a ddition, an embargo of his g oods obt ained through a co ntract $w$ ith h is Majesty (that $w$ as never c ompleted) $w$ as d eclared. A lso, ke eping in $m$ ind the Laws of the Indies (Municipalities), specifically Law VI, Title V, Book IV, in the case that a contract is not fully a dhered $t o, t$ he de ficient pa rty c ould $l$ ose all th at $h \mathrm{e} h$ as $b$ uilt, to include $\mathrm{f}$ arms a nd $\mathrm{r}$ anches. $\mathrm{S}$ ince t he a greement $\mathrm{w}$ as not ke pt i $\mathrm{n} t$ otality, a $\mathrm{n}$ inventory was initiated, followed by an embargo on a ll of the properties of Don Juan Chourio. This was essential in order to provide a proper accounting for His Royal $\mathrm{M}$ ajesty an $\mathrm{d} h$ is o fficials, an $\mathrm{d} t$ hereby $\mathrm{t} o$ aw ait $\mathrm{H}$ is $\mathrm{M}$ ajesty's $\mathrm{r}$ oyal determination in the matter.

In the meantime, the properties of Don Juan Chourio remain in trust. For all of $t$ hese dut ies, $\mathrm{D}$ on $\mathrm{J}$ oseph $\mathrm{C}$ onejero $\mathrm{y}$ Borbua i s appointed $\mathrm{t}$ he chief accountant and trustee. He will work together with Don Diego Duran, who will serve as $t$ he $o$ fficial $r$ ecorder. $T$ hese $t$ wo gentlemen $w$ ill act $i \mathrm{n} t$ he official capacity o $\mathrm{f} c$ onducting $t$ he $i$ nventory a nd $s$ upervising $t$ he e mbargo of $t$ he properties of Don Juan Chourio in the Valle de Santa María. And the captain of the fort at Perijá, Don Rafael Nebot, with the attached government recorder Don Gregorio García, keeping in mind that all that will be discovered at this locale will become the ultimate property of His Majesty in accordance with the previously cited law. As a consequence, the estates that were previously financed for twenty thousand pesos in the Valle de S anta María are being mortgaged, to include the house 1 ocated in P erijá. E qually, these properties a re to b e mo rtgaged in the amount of three thousand two hundred and thirty nine pesos and three reales in accordance with the decree of the court. It was then appealed to the High Court of His Excellency, and is now pending a decision, with no f urther properties of Don Juan Chourio having been discovered.

Some furniture, how ever, w as di scovered in the hous e w here D on J uan Chourio $\mathrm{w}$ as resident, but it $\mathrm{w}$ as not de termined to be his. The furniture $\mathrm{w}$ as valued at a pproximately $\mathrm{t}$ wo hundr ed $\mathrm{p}$ esos. Unfortunately, this $\mathrm{w}$ as $\mathrm{n}$ ot ev en enough to pay for his internment. To pay for the cost of his burial, we appeal to the generosity and wisdom of His Excellency.

May Our Lord protect His Excellency and bless Him with many years!

Maracaibo, the $28^{\text {th }}$ of November 1757.

-Francisco de Ugarte $^{7}$

\footnotetext{
${ }^{7}$ Francisco de Ugarte to José Solis Folch de Cardona, 28 November 1757, Archivo Histórico Nacional de Colombia (Ciudades de Venezuela), Catálogo R-3:110-113, Public Library, Mérida, Venezuela.
} 
The prosperity enjoyed by Chourio up unt il the time of his de ath indicates a degree of success in his operations, which no doubt filtered down to the blacks in his charge. It appears as though circumstances in the Sur del Lago may have worked to the advantage of Chourio's blacks from 1723-1757. The Serranía de Perijá and its immediate environs were populated by various indigenous groups unw illing to simply roll over and let the S panish C rown us urp their 1 ands. Because these lands were on the periphery of the S panish American Empire, and be cause the king $\mathrm{w}$ as he sitant to s upport the e fforts of a F renchman during an a ge of British a scendency, Chourio $\mathrm{w}$ as una ble t o $\mathrm{r}$ eceive $\mathrm{t}$ he 1 ogistical and $\mathrm{m}$ ilitary $\mathrm{s}$ upport he $\mathrm{n}$ eeded $\mathrm{f}$ rom $\mathrm{S}$ pain t o support the expansion of s ettlements in the a rea. Being left to his ow $\mathrm{n}$ r ecourse, a s it w ere, Chourio needed to generate his own monies from the sale of agricultural products, mostly cacao, to European markets. The funds generated from these enterprises could then be used to purchase arms a nd $m$ unitions in Europe for $t$ ransport ba ck to the Sur de 1 Lago, whence they c ould be deployed against the intransigent Native American population.

In the meantime, Chourio experienced more difficulties. The Europeans were g rowing impatient in the face of a fierce indigenous threat, and w ere steadily abandoning the area. In accordance with the disposition document of 28 November 1757 that bequeathed estates, farms, ranches and other property to Chourio's son-in-law, it appears that Chourio continued to buy up sundry properties a s they were abandoned b y E uropean s ettlers. ${ }^{8}$ That $t$ his property was assigned by the court in Maracaibo to his son-in-law may be indicative of Chourio having only one child, a daughter that survived at least until his death.

All of this meant that between 1722 through 1757 Chourio had to increasingly rely on the blacks he $\mathrm{h}$ ad $\mathrm{t}$ ransported $\mathrm{t}$ o the a rea for $\mathrm{d}$ efense of $\mathrm{t}$ he vi llage a nd mission, $\mathrm{pl}$ anting a nd

\footnotetext{
${ }^{8}$ Ibid.
} 
harvesting of co mmercial p roduce ( principally cacao), as $\mathrm{w}$ ell as the defense and productive redeployment of abandoned properties.

The extant chronicles of Perijá seem to support this interpretation. Of the history of the region, it can be garnered that the date most often cited for the foundation of the La Villa del Rosario i s, i ndeed, 9 M ay 1722, c onforming t o the r oyal or der g iven t o J uan de Chourio e Iturbide by the S panish ki ng. H owever, there are s ome di screpancies ove $\mathrm{r}$ this. T he Zulian historian $\mathrm{J}$ uan $\mathrm{B}$ esson $\mathrm{i}$ ndicates $\mathrm{t}$ hat $\mathrm{t}$ he vi llage $\mathrm{w}$ as $\mathrm{r}$ eally established $\mathrm{t}$ hree years 1 ater $\mathrm{b} \mathrm{y}$ Chourio's heir and successor, Manuel García de Peña, the first "Marqués de Perijá." While the king of Spain had ordered the "pacification of the Indians" in these lands, it was not until 1775 that $t$ he governor of Maracaibo, $\mathrm{F}$ rancisco $\mathrm{d}$ e $\mathrm{S}$ anta $\mathrm{C}$ ruz, or dered that $\mathrm{t}$ he ki ng's de cree respecting the region of Perijá actually be carried out to its conclusion, indicating that the task had remained un finished. A nd a ccording to the chronicler of the village, O scálido Montero, ${ }^{10}$ while $\mathrm{C}$ hourio $\mathrm{r}$ eceived $\mathrm{t}$ he ki ng's or der t o $\mathrm{p}$ acify the Indians a nd po pulate $\mathrm{t}$ he $\mathrm{z}$ one $\mathrm{w}$ ith European settlers in 1722, it was not until the following year that he was able to begin the work by deploying 150 Africans to "open roads and construct fortifications" so that in 1724, La Villa del R osario w as r eady to o pen $i$ ts gates and $r$ eceive $i$ ts first E uropean s ettlers. ${ }^{11}$ This fi rst

9 Germán Montero Alcalá, "Villa del Rosario,"

http://www.pueblosdevenezuela.com/Zulia/ZU-VillaDelRosario.htm, accessed 4 August 2010. Montero Alcalá indicates an assertion allegedly made by the Zulian historian Juan Bautista Besson Lalinde (1881-1951), who authored La Historia de Zulia, 1499-1950, 5 vols. (Maracaibo: Hermanos Belloso, 1943-1951), out of print and currently unavailable. Besson Lalinde served in many appointed and elected posts in the Venezuelan federal government. Interestingly, following Chourio's death, Manuel García de Peña m oved out of the $\mathrm{S}$ ur del Lago an $\mathrm{d}$ into a $\mathrm{p}$ alatial residence in Mar acaibo, which today serves as a ci vil registration o ffice. I $\mathrm{n}$ es sence, h e b ecame an ab sentee $\mathrm{l}$ andlord, $\mathrm{n}$ ot $\mathrm{t}$ aking the car e that $\mathrm{C}$ hourio $\mathrm{d}$ isplayed in managing the vast properties and its attendant black workers. See Hennel Huerta, "Maracaibo: De Botica Nueva a Cobeca, 100 años de historia," http://www.lamaracucharadio.com/NOTICIAS/BoticaNueva.htm (4 August 2010).

${ }^{10}$ Pedro Ramón Estrada, “El Zulia se engrandece de cronistas,” El Regional del Zulia (Cabimas), $26 \mathrm{~J}$ une 2010. This newspaper article details the appointment of local Rosario attorney, Oscálido Montero, as the official historian for the Villa de Perijá in accordance with a d irective from the Zulia branch of the Asociación de Cronistas. This clarification is provided in or der to a void c onfusion with Germán M ontero A lcalá, who provides on -line to urist information on towns and villages throughout Venezuela.

${ }^{11}$ Montero Alcalá, "Villa del Rosario." 
contingent of whites was primarily from the Canary Islands, augmented by some from the city of Maracaibo, approximately100 kilometers to the north. ${ }^{12}$

The anticipated growth in European settlers never materialized. Fifty-one years later, in 1775, the Catholic bishop from Caracas, Mariano Martí, arrived at La Villa del Rosario de Perijá, to take count of the church's flock in the entire region. He counted only $488 \mathrm{~s}$ ouls residing in 127 houses scattered throughout the Serranía. ${ }^{13}$ This census was not race specific, but only took count of individuals baptized into the Roman Catholic faith. B y 1775, however, the process of miscegenation $\mathrm{w}$ as a lready changing bot $\mathrm{h} t$ he $\mathrm{c}$ omplexion a nd de mographics of $\mathrm{c}$ olonial Venezuelan s ociety, and P erijá, a s s hall be $\mathrm{d}$ emonstrated $\mathrm{l}$ ater i $\mathrm{n} \mathrm{t}$ his $\mathrm{c}$ hapter, $\mathrm{p}$ roved no exception. It is also known that from the outset, white settlement would not be easy. In the very first year of the village, for example, the mission records indicate the internment of a white man killed by the Motilones. ${ }^{14}$ That only four indigenous areas close to the mission were brought under c ontrol by the time of Chourio's de ath m eans that the B asque $\mathrm{c}$ aptain ne ver lived long enough to realize his dream of transplanting a European faith and society to this isolated corner of the $\mathrm{N}$ ew W orld. N evertheless, it a fforded Chourio's A fricans and their de scendents in the region certain freedoms not shared by other Afro-Venezuelans.

Chourio deployed his Africans to shore up the abandoned European settlements from the foothills of the Serranía to the shores of the Sur del Lago. He had to increasingly rely on the Africans because the rate of E uropean d eparture from the area $w$ as ac celerating. D espite the promise of riches from cacao and cattle ranching, the Europeans could not be tempted to remain

\footnotetext{
${ }^{12}$ Gobernación del Estado Zulia, www.gobernaciondelzulia.gov.ve (12 June 2010). There was no reason to doubt the distance stated, as this is an official website of the State of Zulia.

${ }^{13}$ Gustavo Yamarte Ocando, Historia del Zulia (Caracas: Editorial Arte, 1986), 84. See also David M. Cheney, http://www.catholic-hierarchy.org/bishop/bmartim.html (12 June 2010). Bishop Martí was born in Brafim, Spain, in 1720. He served as the bishop of Caracas from 1770 until his death there in 1792.

${ }^{14}$ Tulio Chiossone, Diccionario Toponímico de Venezuela (Caracas: Monte Avila Editores, 1992), 490.
} 
in the Sur del Lago. It was not just that they had to cope with a hostile indigenous population, but the temperatures frequently s oared into the hi gh 90 s and oc casionally above 100 de grees Fahrenheit.

Another factor in the exodus of Europeans from the region was the presence of certain scorpions. A recent study conducted by doctors at La Universidad de Zulia demonstrated that, "Envenoming b y Tityus discrepans (TD) s corpions in nor th-central V enezuela m ainly c auses pancreatic and gastrointestinal complications, whereas the sting by Tityus zulianus (TZ) (western Venezuela) often produces respiratory arrest and death by pulmonary oedema." 15 In the minds of bot $\mathrm{h} \mathrm{S}$ paniards a nd $\mathrm{C}$ reoles, $\mathrm{t}$ he $\mathrm{m}$ ore $\mathrm{t}$ emperate $\mathrm{r}$ egions of $\mathrm{t}$ he $\mathrm{c}$ oast a nd $\mathrm{l}$ ittoral $\mathrm{w}$ ere decidedly pr eferable to the hot and dus ty S ur de 1 Lago, replete w ith i ts ve nomous s corpions. Perhaps these $w$ hites $t$ hought it be neath $t$ heir di gnity t $\mathrm{l} l$ ive in $\mathrm{t}$ his $\mathrm{r}$ egion, $\mathrm{s}$ o f ar $\mathrm{f}$ rom $\mathrm{t}$ he cultured $\mathrm{l}$ ife af forded i $\mathrm{C}$ aracas o $\mathrm{r}$ artagena. " Let $\mathrm{t}$ he indios and negros keep i t," they probably surmised.

\section{Cacao Plantations}

To generate the funds necessary to continue any European settlement schemes in the area, the first action that Chourio had to take was to insure that the cacao plantations were producing abundantly, and that there were a sufficient number of workers for both the harvesting of the cacao and its safe transport up to Maracaibo, either by land or on the lake. T his was crucial, because funds from the Spanish Crown were not immediately forthcoming and nothing could be accomplished unless Chourio undertook the financing by himself.

Some s ocial-economic historians be lieve $t$ hat nearly $t$ he entire $V$ enezuelan co lonial economy was based on cacao. Yes, other agricultural products were produced, such as tobacco

\footnotetext{
${ }^{15}$ Adolfo B orges, et al., "Pancreatic toxicity in mice el icited by Tityus zulianus and Tityus discrepans scorpion venoms,” Investigación Clínica 45:3 (2004), 269.
} 
and wheat. ${ }^{16}$ But these were produced in very small quantities when compared to the output of cacao. F rom the $\mathrm{m}$ id-seventeenth century, $\mathrm{c}$ acao ove rtook the ot her a gricultural e xports a nd dominated Venezuela's colonial economy. Cacao became a monocultural Venezuelan export. It was o riented towards an ex ternal m arket (Europe), an d the co lonial V enezuelan s tate b ecame dependent on it. Cacao plantations were established all along the Venezuelan coast, in Choroní, Ocumare, $\mathrm{C}$ huao a nd $\mathrm{T}$ uriamo, a s $\mathrm{w}$ ell a s in the va lleys of $\mathrm{C}$ aucagua, $\mathrm{C}$ apaya, $\mathrm{C}$ uriepe a nd Guapo. In the interior, they w ere set up i n B arquisimeto, Mérida and Trujillo. Commerce in cacao enriched the white Creole plantation owners beyond measure, but substantially increased the w ork load of the slaves who toiled on the vast estates. To cultivate the cacao, the A frican workers needed to burn off most the ground-cover vegetation, while at the same time preserving and even planting shade trees. In effect, they were reconstructing the physical environment of the region. The owners of the plantations, it should be added, also took precautions to conserve the forests at the he ad of the rivers. This $\mathrm{w}$ as i mportant be cause they $\mathrm{w}$ anted to a ssure the containment of water required for irrigation. ${ }^{17}$

In Chourio's case, the land in the Sur del Lago was well suited for cacao, but the region was ove rrun by hos tile indigenous pe oples. In a ddition, C hourio must have reasoned that his days as an agent for the French Guinea Company were coming to a swift conclusion, and that if he wanted to secure a stable financial future for himself and his family, he would have to find a way to transition into Venezuela's landed cacao aristocracy. Thus, in light of the departure of the Europeans from the area, Chourio had to place increasing control over the cacao operations into the hands of black lieutenants.

\footnotetext{
${ }^{16}$ Estrada, et al., Estudios Sociales, 47.

${ }^{17}$ Ibid., 47-49. See also Brito Figueroa, Estructura Económica, 235-245.
} 
Here is where share-cropping deals may have been struck between Chourio and some of his black foremen, but never recognized by the S panish colonial a uthorities after his de ath. It seems that beginning in the 1740 s, the incorporation of virgin lands by way of us urpation and planting effected changes in the economic relations of slavery. Slave owners acquired new lands practically $\mathrm{f}$ ree. $\mathrm{W}$ hen $\mathrm{t}$ he $\mathrm{s}$ laves $\mathrm{s}$ igned a co ntract of $\mathrm{m}$ anumission with $\mathrm{t}$ heir $\mathrm{m}$ aster, $\mathrm{he}$ promised them freedom in five, ten, fifteen, twenty or twenty-five years, but the slaves were to work virgin land granted by the Spanish Crown to the slave owner, and keep half of what they produced, while turning the other half over to the master. At the end of the specified time, the slaves $w$ ould be come $f$ ree $m$ en a nd $t$ he onc e vi rgin 1 and $t$ hat $t$ hey had $m$ ade $f$ ertile an $d$ productive, would revert to, and remain forever the property of, their former master. ${ }^{18}$

According to Brito Figueroa:

The phe nomenon $\mathrm{f}$ irst $\mathrm{m}$ anifested $\mathrm{i}$ tself $\mathrm{i} n \mathrm{t}$ he pe riod of expansion $\mathrm{f}$ or cacao plantations, with th is fruit becoming the most important export product in Venezuela's agricultural e conomy a nd $\mathrm{w}$ hen, $\mathrm{s}$ till, $\mathrm{t}$ he e nslaving regime predominated in the conquered territory. Nevertheless, the land owners needed to demonstrate that the land they were claiming and a ttempting to o ccupy was, at least, in the process of being $\mathrm{c}$ ultivated and $\mathrm{w}$ as e ffectively and $\mathrm{r}$ apidly be ing transformed into a base of material wealth for the colony. The slaves worked the land because of the freedom promised them. The slaves were, therefore, actually interested in bount eous production. T hey favored the plans of the hacendado. But in these cases, the slave owner was not simply freeing them, but rather selling them their freedom, with the slaves paying in advance with their manual labor. ${ }^{19}$

For the $\mathrm{c}$ ase of J uan de Chourio, there is little reason to doubt that he w ould i gnore a process that was taking place in cacao plantations throughout Venezuela. It would have been to his advantage to enter into such an agreement with his black contingent. After all, the Europeans were not $\mathrm{s}$ taying. $\mathrm{T}$ hey $\mathrm{w}$ ere s elling of $\mathrm{f} t$ heir $\mathrm{l}$ and to $\mathrm{C}$ hourio a s they de parted the a rea or outright a bandoning i t. Looking t o t he $\mathrm{f}$ uture, a nd be lieving i $\mathrm{t}$ the i nitial pr omise of his

\footnotetext{
${ }^{18}$ Brito Figueroa, La Esctructura Económica, 363.

${ }^{19}$ Ibid.
} 
enterprise, Chourio most likely entered into such manumission and share cropping negotiations. He could secure his land in this manner or lose everything to the Motilones. Since Chourio died before most of those contracts could be fulfilled, however, it appears as though his heir and the courts de cided a gainst the interests of the S ur de 1 Lago bl acks, ha ving put a 11 of C hourio's property, including them, in "trust." ${ }^{20}$ This failure to honor contracts m ost 1 ikely explains the massive infusion of runaway blacks to the cumbes in the Sur del Lago in the period of 1758 1800; a nd these w ere bl acks w ho had s eemingly been s atisfied to $\mathrm{w}$ ork for $\mathrm{C}$ hourio and his economic interests until Chourio died and representatives of the colonial system turned against them. ${ }^{21}$

Of course, some may conjecture that Chourio never entered into manumission and share cropping negotiations with the members of his black contingent. But one can reasonably assume he did, for the cacao plantation owners across Venezuela were doing the same; and as it will be demonstrated in the next section, it was Chourio's Imbangala blacks who or ganized a fugitive slave settlement following his death. They turned from cooperating with Chourio to joining up with the Native Americans and fighting the Spanish. His heir moved up to Maracaibo and was taking little interest in managing his inherited estates in the Sur del Lago. The blacks would not have run off to a cumbe if they enjoyed even a modicum of the freedom granted them by the pragmatic Basque. It looks as though Chourio must have promised the blacks their freedom to keep them hanging on, or the bl acks w ould have s cattered to the wind long b efore Chourio's death. They definitely had no desire to work for Manuel García de Peña, who most likely did not share in Chourio's desire to pacify the Native Americans and spread Christianity. He was going

\footnotetext{
${ }^{20}$ Francisco de Ugarte to José Solis Folch de Cardona, 28 November 1757, Maracaibo.

${ }^{21}$ Brito Figueroa, La Esctructura Económica, 362 (map of Venezuelan cumbes, 1550-1800). See Appendix C for a reproduction of this map.
} 
to squeeze the blacks for every peso he could wring out of them, even if it killed them all. And that was not something that Chourio's blacks could fathom or tolerate.

\section{Cattle}

Another significant, income-generating activity for Chourio in the Sur del Lago was that of cattle herding and dairy production; and according to one Perijá journalist and chronicler, both cattle and d airy "have moved the vi llage's (Rosario's) e conomy s ince i ts ve ry foundation."22 Even today, the Sur del Lago remains one of the prime sources of beef and dairy products for the entire country. $^{23}$

Cattle ar rived in Venezuela al ong with the conquistadores. The climate $\mathrm{w}$ as favorable throughout Venezuela, and this facilitated the rapid expansion of cattle ranching throughout the country. Along with the he ads of dom estic cattle, free-ranging cattle w ere added, rounded up from throughout the vast geographical expanse of the country. By the mid-seventeenth century, cattle ranchers were extending their reach into areas that had largely remained unpopulated, and this process continued well into the twentieth century. S urprisingly, beef production and dairy farming did not do as much damage to the environment as one might first suspect. The slaughter of the $\mathrm{c}$ attle, be sides providing m eat, a lso s erved to produce 1 eather goods. T hese w ere a lso important products derived from the extensive cattle exploitation. The thinning of the herds to produce leather goods a lso ke pt the $\mathrm{c}$ attle from over-grazing. $\mathrm{T}$ his $\mathrm{w}$ as i mportant be cause it prevented s oil e rosion a nd he lped to pe rpetuate the i ndustry throughout the r egion up $t$ o the

\footnotetext{
${ }^{22}$ Gastón Fernández, “288 años de la fundación de La Villa del Rosario,” http://perija.com/?p=2040, on-line daily news of 9 May 2010, accessed 4 August 2010.

${ }^{23}$ Janice Bauman a nd L eni Y oung, Guide to Venezuela (Caracas: E rnesto A rmitano, 1981), 470 . The Guajiro Indians share productive cattle and dairy regions in the Sur del Lago with the Afro-Zulians. Cattle are extremely important to both of these groups because their family diet consists of meat and milk products. Because "cattle are the basis for wealth" in this region, the Guajiro are reluctant to eat them. They use the milk to make cheese and butter, as well as barter the animals for goods. The Guide also notes: "Some Guajiro men work .....as cow hands on the ranches west and south of the lake." Those ranches in the south are largely black owned.
} 
present day, providing substantial and m eaningful employment for many Afro-Zulians. ${ }^{24}$ In contrasting c acao and $\mathrm{c}$ attle, it is $\mathrm{c}$ lear that cac ao b etter s erved the e conomic interests of the white ow ners of the big plantations, increasing the numbers of black w orkers who engaged in repetitive toil on them. On the other hand, cattle herders had free reign to go almost anywhere they w anted. T heir geographic di stance from the locus of control bought them time to think, plan and take decisive actions in defense of freedom when the opportunity presented itself. Also, the cacao was suited only to limited areas, but cattle herding helped to open up an entire country and the northern tier of a continent.

Clearly, c attle h erding was c onducive t o t he e xpansion of S panish c ontrol s outh of Maracaibo. However, because the Spanish Crown failed to provide a sufficient military presence to secure the area against indigenous incursions, Chourio from the start needed to deploy at least 25 percent of his black contingent in guarding the perimeters of the settlement. To get the most out of these A fricans thus arrayed, Chourio armed them and placed them in charge of herds of cattle. T herefore, w hile they s tood guard against indigenous a ttacks, they also tended to the cattle, protecting the herd from wild animals and rustlers. But the most important benefit to the blacks under Chourio's command was that they were working in an economic sector they were familiar with back in Africa, cattle raising, and they were granted the freedom to roam free and armed in the Serranía de Perijá.

The hi storical record reveals that a s maller proportion of A fro-Venezuelans worked as cattle ranchers than in other agricultural sectors. Miguel Acosta Saignes, one of the first AfroVenezuelan historians, notes that, "We have to keep in mind that the penetration of the Llanos occurred 1 ate i $\mathrm{n} \mathrm{V}$ enezuela. O nly i n t he m id-seventeenth c entury was the Apure R iver discovered. The llanero (cowboy) or iginated, principally, in the first decades of colonization,

\footnotetext{
${ }^{24}$ Estrada, et al., Estudios Sociales, 49.
} 
when $\mathrm{t}$ he $\mathrm{m}$ issionaries i $\mathrm{n} \mathrm{W}$ estern $\mathrm{V}$ enezuela $\mathrm{t}$ aught $\mathrm{i}$ ndigenous pe oples $\mathrm{t}$ he $\mathrm{W}$ ork of $\mathrm{c}$ attle ranching." 25 Saignes ad ded that $\mathrm{b}$ ecause of $\mathrm{t}$ he $\mathrm{l}$ ate en try o $\mathrm{f}$ cat tle $\mathrm{r}$ anching i $\mathrm{n} \mathrm{V}$ enezuelan history, "it was only in the eighteenth century that a black and mixed-black population began to appear in the Llanos and other parts of Venezuela, engaged in this occupation." 26 Nevertheless, a min ority of A fro-Venezuelans $\mathrm{d}$ id w ork cat tle, an $\mathrm{d} \mathrm{S}$ aignes emphatically s tates that at the beginning of the eighteenth century, some black slaves were already being sent to the Llanos and other areas of Venezuela to herd and tend cattle. This was an important step in Afro-Venezuelan history because, "Many times the blacks who were sent out as cat tle ranchers came to o ccupy leadership pos itions later in hi story. For example," said S aignes, "when we study Cimarrones (fugitive slaves), we find that after 1750, many of them that led insurrections were llaneros who had surely learned the art of cattle ranching and could, therefore, provide needed leadership skills in tending and directing both cattle and men.",27

One of the best examples of this can be found in the life of the three-time Venezuelan president, José Antonio Páez. He was born as the last of eight children in a modest home on the banks of the Curpa River ne ar the village of Acarigua in the Llanos p rovince of Barinas to a white Creole civil servant and storekeeper, Juan Victorio Páez, and an Afro-descendent mother whose family were cattle ranchers. As Páez' father died early in the young man's life, he moved to the ranch of his m other's family in S an J osé de Guama, where h e lived the life of a true Ilanero, learning the trade of cattle ranching and developing excellent skills in horsemanship and martial arts. A t the age of 20, Páez married Dominga Ortiz, who parents were both deceased, and moved her into his mother's house. In that same year, he joined the revolutionary army and was qui ckly recognized for his s kills a s both a e questrian and 1 ancer, going from victory to

\footnotetext{
${ }^{25}$ Miguel Acosta Saignes, Vida de los esclavos negros en Venezuela, 194.

${ }^{26}$ Ibid., 195.

${ }^{27}$ Ibid.
} 
victory in numerous battles waged against Spanish forces over the next twenty years. ${ }^{28}$ Bolívar appointed Páez as a general and his chief of staff. Páez is most noted for his comment made on 30 April 1830 in San Carlos, Venezuela, after being elected as president of the new Republic of Venezuela by the Constituent Congress, and sent to Bolívar: "My sword, my lance, and all of my milita ry tr iumphs a re 1 ain dow $n$ in the most respectful obe dience to the de cisions of the law. $" 29$

The case of Páez also demonstrates that, without a doubt, those few blacks who worked as cat tle $r$ anchers enjoyed u nprecedented freedom an $d$ acc ess to social mobility $n$ ot generally available to those toiling in other sectors. It also allowed them contact with indigenous peoples of $\mathrm{t}$ he $\mathrm{i}$ nterior a nd ot hers pa ssing $\mathrm{t}$ hrough unp opulated $\mathrm{z}$ ones, a nd a fforded $\mathrm{t}$ hem num erous chances to $\mathrm{r}$ un away from their m asters, when s uch oppor tunities pr esented themselves, thus being in a position to help other blacks escape as well.

As for Chourio's blacks that worked the cacao plantations, they must have felt betrayed when not $r$ eceiving their promised $m$ anumission. F leeing from the $S$ erranía t o m ore s outhern regions of the S ur del Lago, they met friendly b lack cattle men completely familiar with the interior terrain to help them on their way to freedom. Interestingly, the very term for runaway slaves, $\mathrm{m}$ aroons, finds $\mathrm{i}$ ts de rivation from cimarrones, which, in t urn, fixes its or igins a mong Spanish cattle herders. Apparently, a cimarron was simply any animal (but usually a steer) that had escaped its domestic condition and returned to the wilds, thus reverting to a savage state. ${ }^{30}$ The a pplication of this term to fugitive bl ack s laves be ckons a de construction that i nvokes a

\footnotetext{
${ }^{28}$ Coronel Juan José Aguerrevere S., ed., Fuerzas Armadas de Venezuela: Organo del Ministerio de la Defensa 259 (October-December 1973): 2-37. This military journal contains numerous and anonymously written articles related to the life of General José Antonio Páez,

${ }_{29}$ Ibid., S ee al so Guillermo M orón, "Historia d e V enezuela: J osé Antonio P áez," http://www.auyantepui.com/historia/paez.html (5 October 2002).

${ }^{30}$ Bastide, African Civilisations, 46.
} 
racist view of the world on the part of the European colonialists, that being that Africans can be classified with animals and in the context of animal behavior, and hence blacks were considered a s ub-human s pecies. It additionally i mplies that a nything be yond the s cope of E uropean civilization was savage, and difficult, if not impossible, to tame.

\section{Fugitive Slaves}

Following Chourio's death in 1757 and up to the declaration of Venezuelan independence in 1811, it appears as though the institution of slavery in the Sur del Lago, and Spanish colonial society i $\mathrm{n}$ V enezuela g enerally, w as al ready $\mathrm{n}$ earing a s tate o f t otal c ollapse. A fricans an $\mathrm{d}$ African-derived peoples w ere es caping in ever increasing $n$ umbers from the cl utches of their masters, f ollowing a 1 ong tr adition o f e stablishing $\mathrm{f}$ ugitive $\mathrm{s}$ lave $\mathrm{s}$ ettlements, o $\mathrm{r}$ ma roon communities, in the Venezuelan interior.

In the $\mathrm{P}$ rovince of $\mathrm{M}$ aracaibo, for ex ample, $\mathrm{it}$ is $\mathrm{s}$ aid $\mathrm{t}$ hat al $\mathrm{l} \mathrm{w}$ ho $\mathrm{d}$ esired t $\mathrm{o}$ es cape enslavement could find refuge in the maroon communities established there along the extreme southern s hores of the 1 ake. ${ }^{31}$ They kne w they w ere getting c lose w hen they c ould he ar the distinct mu sical s yncretism o f th e C himbángueles, th e liv ing A ngolan d rums $\mathrm{d}$ iscussed in Chapter 3. H owever, these drums also served as a warning to any whites with ideas of hunting down and capturing any escaped slaves that proceeded further only at their own peril and the risk of losing their lives. Once a fugitive slave made it to the maroon settlement in the Sur del Lago, he/she was considered safe. A nd as any maroon could find refuge there, it not only became a place in Venezuela where the Imbangala culture survived, but other African social artifacts from a diverse array of backgrounds as well. ${ }^{32}$ But it was here that the music of the Angolan drums

\footnotetext{
31 José G regorio B racho R eyes, “El culto de San Benito en el Sur del Lago de Maracaibo. Una propuesta de acercamiento desde la antropología de la música,” Boletín americanista 47 (1997-Annual), 45-75.

32 Jesus García, África en Venezuela (Caracas: C uadernos L agoven, 1990) , 8 0. This book s tates: “...Chimbángueles is a word of Bantú origin: Imbangala of Angola, or the Mbangala, a Congolese ethnic subgroup
} 
served as a weapon of resistance for the Maroons organized in the cumbes of the Sur del Lago. These cumbes were set up in the remote area surrounding Bobures, right on the lake, and that once s erved as grazing areas for $\mathrm{c}$ attle. ${ }^{33}$ The $\mathrm{r}$ esidents of the cumbe supported themselves through s ubsistence a griculture and trading w hat little s urplus they had in foodstuffs with the local Native American population, with whom they also began to merge out of common interest against a mutual threat. T he sites did not afford e asy accessibility, since they w ere or iginally chosen in areas that discouraged cattle rustlers. The cumbes were protected by fortifications in the form of $\mathrm{f}$ ences a nd hi dden di tches. T heir pr incipal $\mathrm{w}$ eapons $\mathrm{w}$ ere $\mathrm{t}$ he A ngolan $\mathrm{d}$ rums (psychological $\mathrm{w}$ arfare) and machetes. The exact $\mathrm{d}$ ate that these cumbes were es tablished is unknown, but most likely in the latter half of the eighteenth century. What is known is that they enjoyed s pectacular growth, pa rticularly i $\mathrm{nt}$ he $\mathrm{t}$ wenty years pr ior $\mathrm{t}$ o $\mathrm{t}$ he de claration of Venezuelan independence and Bolívar's calls for the abolition of slavery. ${ }^{34}$

The cumbes also allowed for increased $m$ iscegenation b etween $b$ lacks a nd o ther $r$ acial groups, particularly Native Americans. This, however, was swiftly diminishing the percentage of una ssimilated bl acks i $\mathrm{n} t$ he ove rall $\mathrm{V}$ enezuelan popul ation, a nd e ssentially boos ting $\mathrm{t}$ he pardos to the most populous group, which is still the case of Venezuela's demographic in 2010. In this section we will examine these historical trends, such as increasing co operation between blacks and Native Americans.

For the blacks in the Sur del Lago, it appears as though a goodly number had joined up with s ome of the indigenous peoples with whom Chourio's original black contingent had been

located on the banks of the Banguí River, on the bor der of the Popular Republic of the Congo and the Central African Republic. Among the Mbangala, we can observe dances with skirts identical to those in the Sur del Lago de Maracaibo."

${ }^{33}$ Michelle Ascencio, San Benito: ¿Sociedad Secreta? (Caracas: Universidad Central de Venezuela, 1976), 16. "...Bobures was at one time un pueblo palenquero, a village of cimarron slaves."

${ }^{34}$ Acosta Saignes, Vida de los esclavos, 262. While there were only three cumbes at the end of the sixteenth century in $\mathrm{V}$ enezuela, a nd ni ne a $\mathrm{t}$ the e nd o f the s eventeenth century, by 1800 there were a t otal of 56 act ive cumbes scattered throughout the national territory. 
fighting. ${ }^{35}$ This may have also been a factor that helped, in the long run, to preserve some of the cultural patterns of the Angolan Imbangala. Bastide believes that elements of African culture in the Americas were best maintained in the confines of societies established by black marrons, or maroons. On the nature of marronage, it cannot simply be viewed in the context of an economic phenomenon. Rather, it can be seen as characteristic of resistance. The various bands that were formed tended to coalesce along ethnic lines. And if they managed to federate into some type of government (kingdom, republic, etc.), as was sometimes the case, the distinct bands did not so much 1 ose their identity as es tablish a pattern of peaceful coexistence. ${ }^{36}$ The ne ed to r eadily adapt in a n ong oing $\mathrm{s}$ tate of $\mathrm{s}$ ituational $\mathrm{c}$ risis $\mathrm{w}$ as a pparent. $\mathrm{T}$ his r equired extensive $\mathrm{c}$ ultural transformations by all parties concerned. More often, it was e asier for blacks and indigenous people to modify the past to $\mathrm{s}$ uit the present than to c reate entirely new societal c ustoms and standards. ${ }^{37}$ In $\mathrm{t}$ his $\mathrm{s}$ cenario, a hi gh d egree of syncretism a nd $\mathrm{t}$ ransculturation $\mathrm{t}$ ook $\mathrm{p}$ lace between bl acks, Native A mericans a nd e ven whites. A ny $\mathrm{m}$ aroon communities, a lthough geographically isolated from European settlements, were nevertheless impacted by the colonial society at large. The maroon communities owed their very existence to the Europeans, for the new systems they were creating for themselves in some way represented attempts at improving the types of societies and hierarchies they were running away from. That some Europeans were

\footnotetext{
${ }^{35}$ Helferich, Humboldt's Cosmos, 81-82. On the evening of 27 October, 1802, on the outskirts of Cumaná, in the far eastern side of Venezuela, the European explorers and scientists, Alexander von Humboldt and Aimé B onpland, survived an attack by a club-wielding renegade. After the perpetrator was subdued and taken into custody, "the attacker told the authorities that he was from the area around Lake Maracaibo, in northwestern Venezuela, and had served on a $\mathrm{p}$ rivateer o ut of Santo D omingo. I $\mathrm{n}$ fact, he was $\mathrm{n}$ ot a full Indian (Native American, a s was first assumed) but what was cal led a zambo, with a mixture of Indian and black blood.... Such mixed-bloods were considered $t o$ be $t$ he on e i nsoluble- and co mpletely undesirable- ingredient in $t$ he $r$ acial melting $p$ ot $o f$ th $e$ colonies... H aving quarreled with his captain, the man had put him a shore at Cumaná when the ship left port." When the colonial authorities questioned him as to why he attacked and attempted to rob Humboldt and his party, he stated that he "had flown into a rage on hearing them speak French, the language of his erstwhile captain." Here is clear evidence that Afro-Zulians were well aware of what was transpiring in Haiti, and that they clearly empathized with L'Ouverture and Dessalines in their struggle to free the western half of the island of Hispaniola from French control.

${ }^{36}$. Bastide, African Civilisations, 51.

${ }^{37}$ Ibid.
} 
also working to establish a radical new order did not escape the attention of sundry Africans of the Diaspora.

The pr ecise European idea that did a ppeal to A fro-Venezuelans, h owever, w as the socalled "Law of the French," more of which will be explained toward the end of this chapter. "In Venezuela," wrote Bastide, "uprisings took place and marron republics were formed, that were known as cumbes. These included that of King Miguel in the sixteenth century, that of Adresote in 1732, a nd above all that e stablished in the Coro region (1795)." ${ }^{38}$ The problem with these fugitive communities lay in certain internal discrepancies. Splits occurred at various levels. For example, al 1 of the $V$ enezuelan cumbes cited by Bastide w ere es tablished on the $\mathrm{b}$ asis of an egalitarian vi sion of $\mathrm{m}$ an and s ociety, yet $\mathrm{t}$ hey $\mathrm{f}$ unctioned in the $\mathrm{s}$ tratified $\mathrm{n}$ ature $\mathrm{o} f \mathrm{r}$ eality. Social or ganization $\mathrm{f}$ requently $\mathrm{c}$ lashed $\mathrm{w}$ ith pr actical a nd e conomic know -how, as $\mathrm{w}$ ell as systems of religious be lief. $\mathrm{S}$ uch $\mathrm{f}$ issures di vided $\mathrm{m}$ aroon $\mathrm{c}$ ommunities, $\mathrm{m}$ aking it $\mathrm{e}$ asier for colonial authorities to subdue them. ${ }^{39}$

Bastide elaborated on this point:

On the one hand, they have a pow erful incentive to a dapt themselves to their ne $\mathrm{w}$ environment, $\mathrm{t}$ o f orge $\mathrm{n}$ ew and i ndividual i nstitutions $\mathrm{f}$ rom $\mathrm{t}$ heir struggle for survival. On the other hand, there is a strong force driving them to maintain their old a ncestral traditions, s ince these a re seen as s ymbolizing their independence (political, no less than cultural), and forming the spiritual cement which binds them all together. Obviously, tensions will be found in any over-all social group; but whereas in Africa there ex ists a functional connection between the various levels of what G. Gurvitch has termed 'sociology in depth,' and all strata- from $t$ he e cological $t$ ot hose e mbodying s ocial va lues or $t$ he $g$ roup conscience- form part of the s ame continuum, in these marron communities a quite different state of affairs prevails. Here environmental determinism and the claims of collective memory come into direct conflict. ${ }^{40}$

\footnotetext{
${ }^{38}$ Ibid., 66.

${ }^{39}$ Ibid., 67.

${ }^{40}$ Ibid.
} 
Those cumbes that endured for the longest time did so because each band realized it was in their best interest to establish and maintain alliances with other bands, all the while keeping true to its own character. A t th is stage, it $w$ as $n$ ot requisite for these $b$ ands to sacrifice their individuality to a s erve a common revolutionary $\mathrm{c}$ ause. The threat of re-enslavement by the

European colonialists pr ovided i mpetus e nough i $\mathrm{n}$ hol ding a ny a lliance $\mathrm{t}$ ogether. ${ }^{41}$ What galvanized t he A fro-Zulians a nd ot her bl acks i $\mathrm{n} t$ he $\mathrm{N}$ ew $\mathrm{W}$ orld $\mathrm{i}$ nto $\mathrm{t}$ aking $\mathrm{c}$ oncerted revolutionary a ctions a gainst the colonial S panish administration w ere $\mathrm{n}$ ew ideas conceived in France and carried out in Saint-Domingue (Haiti).

\section{Black Revolution}

Clearly, A fro-Venezuelans were among the first to be inspired by the French Revolution (1789) and the subsequent abolition of slavery that ensued (1791) in the nearby French colony of Saint-Domingue. The bold actions of the black Jacobins within Venezuela gave impetus to other revolutionary m ovements, and $\mathrm{w}$ ithout $\mathrm{l}$ ater A fro-Venezuelan pa rticipation on $\mathrm{t}$ he $\mathrm{s}$ ide of the patriot forces against the S panish C rown, the first republic w ould have never be en proclaimed and the subsequent independence of Venezuela would have never been assured.

\section{Influence of Haiti: Historical Context}

In the colonial a nd ge ographic va cuum that e xisted in the e arly s eventeenth $\mathrm{c}$ entury Caribbean sailed buccaneers and freebooters that w ere seeking safe harbors for their ships, as well a s provisioning po ints f or their crews. Most of these were French, a long w ith ot her scattered Europeans. They primarily settled on the island of Tortuga off the northern coast of Saint-Domingue in 1630 . W ithin thirty years, the 1 arger F rench contingent $h$ ad expelled the

\footnotetext{
${ }^{41}$ Ibid., 69.
} 
other European interlopers and successfully repelled Spanish incursions from the eastern end of the island. $^{42}$

With the help of African slaves, the French settlers were able to convert their half of the island into one of the $\mathrm{r}$ ichest $\mathrm{E}$ uropean colonies of the $\mathrm{N}$ ew $\mathrm{W}$ orld, even $\mathrm{s}$ urpassing $\mathrm{G}$ reat Britain's Jamaica and Spain's Cuba. C acao from Mexico and Venezuela supplied France with its raw chocolate, while refineries in Bordeaux processed sugar from Saint-Domingue that gave the chocolate its flavor and texture. That sugar not used in cacao processing was converted into rum a nd exported a 11 ov er the know $\mathrm{n}$ w orld. Also, S aint-Domingue $\mathrm{w}$ as know $\mathrm{n}$ for having shipped huge quantities of cotton and coffee back to France. ${ }^{43}$

The problem with th is scenario is th at it $\mathrm{r}$ equired $\mathrm{h}$ alf a millio $\mathrm{n}$ imp orted A fricans to make this e conomic m iracle happen. A nd that huge number of bl acks required 30,000 w hite French colonists to keep them in line. In order to maintain control over such a disproportionate number of A fricans, the white French slave masters kept up the most brutal repression. They exercised the power of life and de ath over their slaves, and did not he sitate to use, and abuse, such vast power. Blacks were frequently seen being whipped in the streets of Port-au-Prince, the capital of S aint-Domingue. A nd in the c ountryside, it w as not unc ommon to s ee di sobedient slaves being buried alive, with their heads left exposed and covered with molasses so that nasty red army ants could finish them off. ${ }^{44}$

As in ot her parts of the $\mathrm{N}$ ew $\mathrm{W}$ orld, $\mathrm{s}$ uch $\mathrm{m}$ altreatment of bl acks c ould not 1 ong be tolerated, e specially b y the bl acks themselves. This s ort of t error produced a $\mathrm{n}$ even 1 arger counter-terror. As blacks in Saint-Domingue escaped these vile conditions, they made their way to $t$ he $\mathrm{m}$ ountainous i nterior. $\mathrm{O}$ ccasionally, ba nds of bl acks would $\mathrm{c}$ ome dow $\mathrm{n} f$ rom $\mathrm{t}$ heir

\footnotetext{
${ }^{42}$ Richard Joseph, Haiti (New York: Nelson Doubleday, 1959), 13.

${ }^{43}$ Ibid., 15-16.

${ }^{44}$ Ibid., 16.
} 
mountain hideouts and raid outlying plantations. One of the most devastating of these incursions was carried out by a maroon slave in 1758, simply known as Mackandal. Swarming down from the hi lls, $\mathrm{M}$ ackandal and hi $\mathrm{s} \mathrm{m}$ en $\mathrm{s}$ et $\mathrm{f}$ ires $\mathrm{t}$ o $\mathrm{t}$ he bui $\operatorname{lding}(\mathrm{s})$ of $\mathrm{n}$ early every white he encountered. B ut as news of his exploits spread, it did not take too long for the French island authorities to discover his hideout, flush him out and burn him alive. ${ }^{45}$

But events on the other side of the ocean would provide the spark to reignite the passion of $\mathrm{r}$ esistance i $\mathrm{n} t$ he $\mathrm{h}$ earts of $\mathrm{t}$ he $\mathrm{b}$ lacks i $\mathrm{n} \mathrm{S}$ aint-Domingue a nd ot her $\mathrm{E}$ uropean colonies throughout the Caribbean and the Americas. Just two years after the National Assembly signed and en acted the Rights of Man and the Citizen in Paris, France (1789), this same body granted political rights to "persons of color." 46

However, it s oon b ecame obvi ous that whites in S aint-Domingue ha d no intention of complying with this law of the French National Assembly. And when two young mulatto leaders organized a protest demonstration and spoke up against the intransigence of the island's white colonists, they were quickly arrested and s mashed to de ath on $t$ he wheel. $\mathrm{N}$ ot long after this brutal display of repression, the blacks of Saint-Domingue began to organize themselves in the mountain forests, planning a great rebellion that would set them free. And free they would be, for if they failed to defeat the French in battle, they reasoned that they would become free at the time of their deaths, with their spirits breaking loose from the physical plane whence they could direct their living kin from the spirit world. ${ }^{47}$ As in Venezuela, it was their religious syncretism that e mpowered them to survive the relentless evil of their masters, and it also provided them with the courage and solidarity to fight back.

\footnotetext{
${ }^{45}$ Ibid., 16.

${ }^{46}$ Ibid.

${ }^{47}$ Ibid., 16-17.
} 
Then, on $\mathrm{t}$ he ni ght of August 14, 1791, $\mathrm{t}$ he $\mathrm{V}$ oodoo dr ums pounde $\mathrm{d}$ a s ne ver be fore, reverberating throughout the western end of the island. The white colonists may have thought it was for a marriage celebration, or some other religious occasion. In a way, it was the latter; but the drums w ere a ctually s ignaling the coming d estruction of the old or der in S aint-Domingue with the rise of a black revolution. T he black s laves w orked the land, but like revolutionary peasants in every part of the world, "they aimed for the extermination of their oppressors." 48

The black revolution w as led by a papaloi or high priest na med Dutty Boukman, who employed V oodoo a s the m edium of hi s c onspiracy. B oukman w as a $\mathrm{J}$ amaican s lave qui te literate i $\mathrm{n}$ A rabic a nd English, but $\mathrm{w}$ as s old by hi s $\mathrm{m}$ aster t o a French pl anter i n S aintDomingue. Boukman's former English master accused him of teaching the other slaves on the plantation how to read and inciting insurrection. The French planter assumed that if he gave Boukman the job of be ing his coachmen, it w ould he lp to pa cify his rebellious instincts. B ut Boukman used his coachman experience to forge connections with other rebellious slave leaders on plantations up and down the Northern Cape and even to regions further south, indoctrinating them into the rites of the V oodoo religion and stirring them up a gainst their French masters. ${ }^{49}$ In spite of all the religious restrictions, the blacks travelled miles in to the forest to sing, dance and practice their Voodoo rites, as instructed by Boukman. But these were a lso oc casions in which they could talk and share political news, and make their plans be yond the white man's range of sight or hearing. ${ }^{50}$

After s ome de liberations, B oukman a nd a council of e lders a greed $\mathrm{u}$ pon a $\mathrm{pl}$ an $\mathrm{t}$ hat encompassed a massive scale and aimed at exterminating the whites and seizing the colony in the

\footnotetext{
${ }^{48}$ C. L. R. J ames, The Black Jacobins, $2^{\text {nd }}$ ed., revision of 1938 e dition, republication of $1963 \mathrm{R}$ andom House edition (New York: Vintage Books, 1989), 85.

${ }^{49}$ Carolyn Cooper, "Haiti- The Price of Freedom,” Jamaica Daily Gleaner (Kingston), 17 January 2010.

${ }^{50}$ James, Black Jacobins, 86.
} 
name of its black population. ${ }^{51}$ With such a bold plan in mind, Boukman gave the signal for attack in the early morning hours of the following day. At dawn, he led 12,000 slaves, half of them women, into the towns and villages surrounding Le Cap François, whereupon they set fire to e very c ane field, grove and pl antation hous e. A nd through the leaping flames, B oukman's blacks wielded their machetes, plunging them into the collapsing bodies of any whites or others who got in their way. ${ }^{52}$

After a few weeks, the rampaging blacks had managed to kill 2,000 whites. H owever, whites from throughout the island c oalesced in the nor th to put do wn B oukman's r ebellion, whereupon 10,000 blacks were captured and hanged. The roadsides were littered with the bodies of blacks hanging from the trees. ${ }^{53}$ Boukman was guillotined by the French in November, with his head publicly displayed in an attempt to dispel the aura of invincibility that he had cultivated among the island's blacks. ${ }^{54}$

These ev ents in S aint-Domingue were r emarkable for s everal r easons. First, the pl an almost succeeded. If not for some delays in carrying out the plans, the whites would not have found the time needed to group for a counteroffensive. Second, as James notes, "That so vast a conspiracy was not discovered until it had actually broken out is a testimony to their (the blacks') solidarity;" ${ }^{55}$ and third, the whites were so bl inded by their ow $\mathrm{n}$ arrogance and de spised the slaves so much, "that they did not believe them capable of organizing such a mass movement on a grand scale." ${ }^{56}$ In other words, the blacks were underestimated. A lso of importance was the prestige gained by the mulattoes. O nce they distanced themselves from the black s laves, but

\footnotetext{
${ }^{51}$ Ibid.

${ }^{52}$ Joseph, Haiti, 18.

${ }^{53}$ Ibid.

${ }^{54}$ Sylviane Anna Diouf and Sylviane Kamara, Servants of Allah: African Muslims Enslaved in the Americas (New York: New York University Press, 1998), 152.

${ }^{55}$ James, Black Jacobins, 86.

${ }^{56}$ Ibid., 87.
} 
now they desired to join them in a fight against a common enemy, the European enslaver. ${ }^{57}$ The whites were fearful and started to make some concessions to the mulattoes. The revolution was underway, and there was no going back.

All of this did not escape the attention of one mixed raced Venezuelan resident in both France and Saint-Domingue. W hen he returned to his home in western Venezuela, he brought with $\mathrm{h}$ im s ome r evolutionary id eas th at attracted the a ttention of ma ny A fro-Venezuelans, to include the descendents of Chourio's A frican contingent. That person, José Leonardo Chirino, and $\mathrm{t}$ he $\mathrm{c}$ ontinuing $\mathrm{i}$ nfluence exercised $\mathrm{b}$ y $\mathrm{t}$ he $\mathrm{F}$ rench a nd Haitian $\mathrm{r}$ evolutions on $\mathrm{A}$ froVenezuelans, is the subject of the next section.

Of course, the potent impact of the Age of Enlightenment, and the F rench and Haitian revolutions that followed it, on Spanish colonial societies is a vast one, indeed, and therefore this dissertation limits its investigation to its effect on Venezuela's blacks, to include those segments of Venezuelan society also constituted with some degree of African bloodline, i.e. the mulattoes, pardos, zambos (black and $\mathrm{N}$ ative A merican), etc., as w ell as the $\mathrm{d}$ escendants of $\mathrm{C}$ hourio's African co ntingent. A $t$ ransfer of $i$ deas $\mathrm{c}$ an $\mathrm{b}$ e $\mathrm{t}$ raced $\mathrm{f}$ rom $\mathrm{t}$ he $\mathrm{r}$ adical ar $\mathrm{m}$ o $\mathrm{ft}$ he $\mathrm{F}$ rench Revolution to the Black Jacobins of the Haitian insurrections, passing on to the social rebellions of Venezuela's blacks in the colonial and post-colonial times. ${ }^{58}$

In just four short years since the slave rebellion in Saint-Domingue, between 10 and 12 May, 1795, zambos, free blacks and slaves on the peninsula of Coro in west central Venezuela, being i nspired $b$ y bot $h \mathrm{t}$ he $\mathrm{F}$ rench $\mathrm{R}$ evolution a nd the $\mathrm{c}$ harismatic $\mathrm{T}$ oussaint $\mathrm{L}$ 'Ouverture's interpretation a nd a pplication of it in the $\mathrm{C}$ aribbean, $\mathrm{u}$ nited a nd a ttempted to e mploy s imilar seditious actions against the Spanish colonial authorities. They saw republicanism as the key to

\footnotetext{
${ }^{57}$ Ibid., 89.

${ }^{58}$ Brito Figueroa. 30 Ensayos, 405.
} 
affecting th eir lib eration. $\mathrm{T}$ heir $\mathrm{b}$ attle $\mathrm{c}$ ry $\mathrm{w}$ as " Death to th e $\mathrm{T}$ yrants!" $\mathrm{T}$ heir le adership advanced a program that would abolish special privileges for white persons as they then enjoyed, above and beyond that of all others in the colonial, caste society. This rebellion was instigated and led by J osé Leonardo Chirino, but was forcefully extinguished by colonial soldiers on 12 May 1795, headed by the justicia mayor (chief justice) of Coro, don Mariano Ramírez Valdenay. The fate of the revolutionaries $w$ as similar to those who had $g$ one be fore them on $t$ he path of freedom, and would follow after them as well. They were overcome by massive force of arms, and those that survived were jailed and tortured, with their leadership being summarily executed. This upr ising on $\mathrm{C}$ oro, however, i ntroduced ne w pol itical ove rtones $\mathrm{w}$ ith $\mathrm{c}$ onnections t o the French Revolution.

\section{Figure 5.1: José Leonardo Chirino}

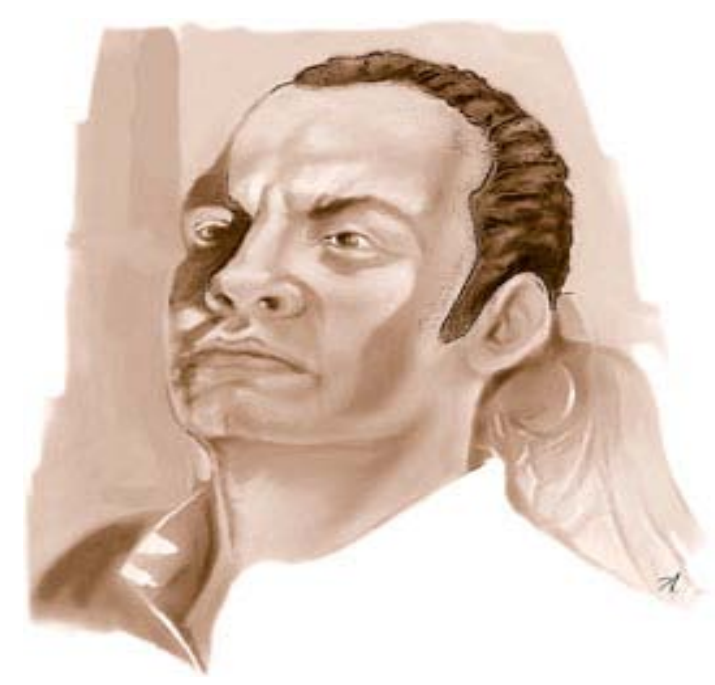

José Leonardo Chirino, of Angolan de scent, led an insurrection at Coro (1795) inspired by the revolutionary e vents then $\mathrm{t}$ aking $\mathrm{pl}$ ace in $\mathrm{S}$ aint-Domingue (Haiti). $\mathrm{M}$ any hi storians $\mathrm{c}$ onsider Chirino a precursor to the Venezuelan liberators Francisco Miranda and Simón Bolívar.

Source: http://www.kalipedia.com/kalipediamedia/historia/media/200808/01/hisvenezuela/ 20080801klphishve_2_Ies_SCO.jpg 


\section{José Leonardo Chirino}

José Leonardo Chirino was the son of a free Native American woman and a black slave who belonged to a criollo ${ }^{59}$ family, from whence he received his name. He was born as a free zambo and toiled as a day laborer, cultivating the ground on the hacienda of Don José Tallería, where his future wife was also working. ${ }^{60}$ This slave woman of Tallería, María de los Dolores, had three children with Chirino, these being María Bibiana, Rafael María and José Hilario. The hacienda owner would frequently engage in business trips to the Antilles, and on more than one occasion Chirino accompanied him. It seems that Chirino de veloped an intense in terest in the ideas and practice of the French Revolution while travelling outside Venezuela to the island of Saint-Domingue w ith $\mathrm{T}$ allería. O f c ourse, $\mathrm{t}$ his i sland t oday i s c omprised of $\mathrm{t}$ hat $\mathrm{t}$ erritory constituting both Haiti on its western end, and the Dominican Republic on its eastern side. The effects of the French Revolution were manifest w orldwide, but e specially in her own colonies. The area that now makes up $\mathrm{H}$ aiti, i.e. the French-speaking portion of the isle, was in political turmoil over these r evolutionary i deas and i deals then e manating from Paris, the e picenter of political enlightenment. Thus, both Tallería and Chirino were exposed to the virus of Republican ideas, and, more importantly, of the existence of a strong abolitionist movement in France and other parts of Europe.

Tallería was co gnizant of Chirino's intense interest and manifest reactions, and became somewhat concerned over whether or not his talented free black w ould remain in his e mploy. But a s for Chirino, he wasn't w orried about the matter, but stimulated by it. T he n otions of liberty a nd e quality for hi s bl ack br others a nd s isters ba ck hom e propelled hi m t o c onsider

\footnotetext{
59 In V enezuela, this word denotes a Latin American of pure or o verwhelmingly Spanish-European heritage, but born in the New World. It is the Spanish word for Creole.

${ }^{60}$ Newspaper supplement dispersed throughout Venezuela in 2002 in cooperation with Fundación Banco Mercantil and CANTV, the national telecommunications corporation, Rostros y personajes de Venezuela: Crear la República.
} 
drastic actions. $\mathrm{N}$ ever had e ven the existence of $\mathrm{s}$ uch a r evolutionary concept or m ovement dawned upon him until his arrival in Paris. ${ }^{61}$

Back in Venezuela, Chirino joined a group of conspirators who clandestinely met in the mill of the Mancanillas farm, l ocated on t he o utskirts of $\mathrm{C}$ urimagua, in the pr esent $\mathrm{s}$ tate of Falcón. A mong those present w as J osé C aridad G onzález, w ell i nformed a bout $\mathrm{t}$ he F rench Revolution and the bl ack insurrections in S aint-Domingue. H e w as an ex-slave of A ngolanCongolese descent, co mmonly referred to in Venezuela as a luango, ${ }^{62}$ and served as Chirino's right-hand man. From May 3, 1795, they began preparing the insurrection, which broke out on the 10th. C hirino and his partisans went to the hacienda E1 S ocorro, where they adopted his revolutionary program: establishing what they called "The Law of the French," i.e. a republic for Venezuela; elimination of slavery and social classes; abolition of racial privileges; and repeal of the excise tax. ${ }^{63}$ Almost all of the blacks recruited by Chirino were of the luangos or the minas groups. ${ }^{64}$ The idea was to take all the bigger farms and plantations in the area, recruit more men from among the liberated slaves, assure clear passage to the city of Coro, and then capture it as their ba se of ope rations in further f reeing bl acks throughout $\mathrm{V}$ enezuela and p roviding a $\mathrm{s}$ afe haven for any runaway slaves or others seeking asylum and wishing to join the revolution. After conducting s everal i ncursions ont o t he 1 arger $\mathrm{p}$ lantations i n t he a rea a nd ki lling their w hite owners, $\mathrm{C}$ hirino and hi $\mathrm{s} \mathrm{m}$ en $\mathrm{m}$ ade the $\mathrm{c}$ ritical mistake of $\mathrm{d}$ elaying the $\mathrm{t}$ aking of Coro. $\mathrm{He}$

\footnotetext{
${ }^{61}$ Ibid.

${ }^{62}$ Acosta Saignes, Vida de los esclavos, 151. L oango is a region situated to the north of the Congo River. There was a $\mathrm{F}$ rench $\mathrm{p}$ rocessing ar ea there for Africans t o $\mathrm{b}$ e $t$ ransported to the $\mathrm{N}$ ew $\mathrm{W}$ orld. $\mathrm{H}$ ence, those Africans proceeding f rom that "f actory," to i nclude their d escendants, were r eferred to in V enezuela as luangos. B rito Figueroa refers to this same group as loangos in Las insurrecciones de los esclavos negros en la sociedad colonial venezolana (Caracas: Editorial Cantaelaro, 1961), 67-77.

${ }^{63}$ Brito Figueroa, Las insurrecciones, 71. "Chirino remained in the Sierra applying the Law of the French, or better said, the law of the Black Jacobins of Toussaint L'Ouverture and Dessalines, recruiting soldiers for their army..."

${ }^{64}$ Acosta Saignes, Vida de los esclavos, 152-153. Minas refer to Africans with Akan origins in the Gold Coast, present $\mathrm{d}$ ay $\mathrm{G}$ hana, such a s the Ashanti, F anti, E we, e tc., a nd d erives from the $\mathrm{p}$ rominent $\mathrm{P}$ ortuguese $\mathrm{E} 1 \mathrm{M}$ ina fortress there, that served as a slave factory, or processing point.
} 
probably thought he needed to take some time in reorganizing his forces, especially with the new recruits, but this gave Spanish colonial officials more time to organize the defense. ${ }^{65}$

The revolutionaries w ere r epelled, but many died and ot hers were ar rested. T he more fortunate escaped. Chirino, hunted by the authorities, fled and took refuge in the interior until he was betrayed by an acquaintance in Baragua, whence he was imprisoned in August 1795. After a s hort $\mathrm{t}$ ime, he w as m oved to $\mathrm{C}$ aracas, where the R oyal C ourt c ondemned hi $\mathrm{m}$ t o de ath b y hanging on $\mathrm{D}$ ecember 10,1796 , be lieving he was a cting "as a $\mathrm{n}$ a ctive agent in the crime of subversion." 66 The sentence was immediately carried out in the central plaza. His head was set on an iron lance and placed on the main road out of Caracas leading to the valleys of Aragua and Coro, presumably to serve as a warning to any potential revolutionaries. ${ }^{67}$ His wife and children were condemned to be sold as slaves away from the place where they lived with Chirino: María de 1 os D olores an d R afael M aría, in C aracas, a nd José M aríia B ibiana an d H ilario in P uerto Cabello. $\mathrm{H}$ is wife, how ever, di d not live long e nough to s ee h er s entence $\mathrm{c}$ arried out, a s she became sick and died shortly afterwards. ${ }^{68}$

Chirino's m emory lived on, how ever, a nd i nspired ot hers t o continue t he w ork o f liberation. It should also be pointed out that right before the close of the eighteenth century, in 1799, m ore than one hundred pardos, b lacks, m ulattoes an d $\mathrm{N}$ ative A mericans w ere $\mathrm{j}$ ailed in Maracaibo on the charges of planning a conspiracy to overthrow Spanish colonial rule, establish a republic and abolish slavery. The original plan was to carry out an insurrection in Maracaibo at the same time a slave rebellion was being carried out in Cartagena in the neighboring territory of

\footnotetext{
${ }^{65}$ Brito Figueroa, Las insurrecciones, 75..

${ }^{66}$ Paul Verna, "Chirino, José Leonardo," Diccionario de Historia de Venezuela, $2^{\text {nd }}$ ed. (Caracas: Fundación Polar, 1997), 800-801.

${ }^{67}$ Brito Figueroa, Las insurrecciones, 75-76.

${ }^{68}$ Verna, “Chirino," 800-801.
} 
Nueva Granada (Colombia). ${ }^{69}$ The revolutionaries were counting on the inability of the Spanish colonialists to extinguish two fires at the same time, reasoning that it would tax their military to the ex tremes. That they were on the right track was later proven by Bolívar, Páez, O'Higgins, Santander, S an M artín, Sucre a nd ot her S outh A merican freedom fighters, who e xtended the struggle to the whole of Latin America. It wasn't until 1808, how ever, that the leaders of this plan were revealed to be the pardo Francisco Javier Pirela and the black Francisco Suárez. Two mulattoes served as their lieutenants.

Of Chirino's revolution and the subsequent insurrections he inspired, Afro-Zulians in the cumbe at Bobures and other areas in the Sur del Lago were decidedly onboard. Jesús Angél Parra ${ }^{70}$ chair of the Department of History and a member of the Zulia State History Academy at La Universidad de Zulia in $\mathrm{M}$ aracaibo, $\mathrm{w}$ hen asked $\mathrm{b}$ y $\mathrm{t}$ he a uthor $\mathrm{w}$ hat ha ppened $\mathrm{w}$ ith $\mathrm{t}$ he descendents of Chourio's Africans from 1757 until Venezuelan independence in 1811, responded that: “In V enezuela, in 1795, t he bl ack J osé L eonardo C hirino, w ho ha d c ontact w ith H aiti, became the precursor in launching a rebellion against Spanish colonial control. The majority of the blacks in the Sur del Lago sided with, abetted, or joined the struggle of Chirino and those who would follow in his footsteps." 71

As not ed a bove, $\mathrm{P}$ arra considers $\mathrm{C}$ hirino's m ovement a real revolution. Its pol itical, economic and social significance has been recognized by all historians who have studied it. On the Occasion of the $200^{\text {th }}$ anniversary of the insurrection led by Chirino, the National Executive, the Congress of the Republic, and various cultural institutions in Venezuela, united and accorded honors posthumously on the social activist. Among the acts of commemoration was the unveiling

\footnotetext{
${ }^{69}$ Arellano Moreno, Orígenes de la economía venezolana,123.

${ }^{70}$ Luis Guillermo Hernández and Jesús Angél Parra, Diccionario General del Zulia (Caracas: Editorial Arte, 1999).

${ }^{71}$ Jesús Angel Parra in e-mail to Raymond Keller dated 2 June 2010.
} 
of a plaque at the National Pantheon on M ay 10,1995, w hich of ficially recognized Chirino's presence alongside the other heroes and forefathers of Venezuelan independence. ${ }^{72}$

Chirino $t$ ook pr oactive $s$ teps $t$ o a dvocate $t$ he $r$ ights of $m$ an, $s$ toking $t$ he $f$ ires of revolutionary tendencies among the slaves, the free blacks, the Native Americans, the mestizos, the pardos, the zambos, and all oppressed Venezuelans. Most importantly, Chirino's revolution transformed the Afro-Venezuelans' struggles for freedom from isolated, backward-looking slave revolts a nd 1 inked them $w$ ith $t$ he $r$ evolutionary-democratic a nd $r$ epublican $t$ ide $s$ weeping $t$ he Americas and the entire Trans-Atlantic world.

Because of C hirino's m ovement a nd the on -going Haitian r evolution, $\mathrm{t}$ he $\mathrm{C}$ reoles i $\mathrm{n}$ Venezuela came to the realization that the abolition of the slave trade reflected their commercial interests as a class of the em erging bourgeoisie. W hat they definitely wanted to a void was a repeat of the Haitian experience in their own backyard. And, after a series of stinging defeats in their struggle for independence from S pain, V enezuelan Creole leadership, headed by Bolívar, prematurely p roclaimed, on num erous oc casions, the a bolition of s lavery throughout S panish America. They hop ed $\mathrm{t}$ hey could $\mathrm{w}$ in $\mathrm{bl}$ ack $\mathrm{s}$ upport $\mathrm{f}$ or $\mathrm{t}$ he $\mathrm{B}$ olivarian $\mathrm{R}$ evolution. A nd following these proclamations, Haiti twice provided Bolívar refuge dur ing the period of 1815 1816, even equipping him with money and arms to continue his fight on the mainland. ${ }^{73}$ More about B olívar a nd the A fro-Venezuelans a s t he r evolutionary $\mathrm{n}$ exus a ppears in $\mathrm{t}$ he ne $\mathrm{xt}$ a nd concluding chapter.

\section{Conclusions}

Throughout colonial Venezuela, A fricans and African derived peoples manifested their opposition to slavery in many ways. Some committed suicide, hoping for a better life with their

\footnotetext{
${ }^{72}$ Verna, "Chirino," 801.

73 “Toussaint L'Ouverture and the Haitian Revolution,” Workers Vanguard (New York), Nos. 446 and 447, 12 and 26 February 1988, respectively.
} 
ancestors dw elling in the s pirit w orld. A nd for s ome women, vol untary abortion s pared their children from a future in bondage. A lso, s ome s laves, $w$ ith the a stute us e of t oxic pl ants, poisoned th eir ma ster's food. B astide b elieves that th is la tter a ction b elies the e xistence of African baba-osaim, or medicine $\mathrm{m}$ en, throughout the A mericas and $\mathrm{C}$ aribbean. ${ }^{74}$ And then there were some slaves who would sabotage their work in the fields or mines, or just slow down the i ntensity of their 1 abor a nd pr oduction $r$ ates. T his t ype of $s$ trategy gave $r$ ise to "lazy" stereotypes f or bl acks a mong E uropean s ettler populations. ${ }^{75}$ The m ost $\mathrm{c}$ ommon forms of resistance to enslavement, how ever, were flight and fight, both of which took place in Western Venezuela on a grand scale from 1750-1811.

As $\mathrm{f}$ ar as flight i s concerned, in the $\mathrm{S}$ ur $\mathrm{d}$ el Lago $t$ here a re s mall s ocieties of $\mathrm{t}$ he descendants of runaway black slaves, generically referred to as maroons. They have continued to this day as an ethnic minority, but the resulting Afro-Zulian culture is one of more than mere survival. Following the death of Juan de Chourio in 1757, the ancestors of these blacks ran away from the white settlement a t and a round P erijá and a voided remaining victims by settling in small villages or cumbes along the southern shores of Lake Maracaibo, principally at Bobures. Their descendants have peacefully lived in the Sur del Lago ever since, principally engaged in cattle he rding and agricultural pur suits, generally preferring to keep to themselves. T hey fled from deteriorating and oppressive conditions, and perhaps a breach of promise that they would obtain papers of manumission. $\mathrm{N}$ evertheless, the A fro-Zulians managed to maintain their selfimage as the de scendants of the proud Imbangala w arriors. They di d not 1 et themselves be hemmed in by the prevailing Venezuelan Eurocentric culture. Their relative isolation in the Sur del La go facilitated their political and s ocial formation as one people and one culture. Their

\footnotetext{
${ }^{74}$ Ibid.

${ }^{75}$ Ibid.
} 
escape from s ervitude n ot onl y i nsured their bi ological s urvival, but pe rpetuated their di gnity under conditions which only served to run counter to it.

Insofar as fighting, the Afro-Zulians and other black Venezuelans clearly sided with and assisted, w here pos sible, the e fforts of J osé Leondardo C hirino t o e stablish a ne w o rder in Venezuela, based on the French Declaration of the Rights of Man and the Citizen (1789), as well as the then on-going efforts of the black Jacobins to liberate themselves in Haiti. In this sense, he was a precursor to Simón Bolívar and other Latin American liberators. Therefore, Chirino’s insurrection rightfully can be classified as a revolution, Trans-Atlantic in scope. The Latin verb, revolvere, for e xample, s ignifies to "roll ove r." 76 And that i s ex actly w hat w as indicated in Chirino's actions, a complete roll over and revolutionary transformation of Venezuelan society. He $\mathrm{n}$ ot onl y w anted $\mathrm{t}$ o $\mathrm{r}$ eplace $\mathrm{t}$ he pol itical 1 eadership ( king $\mathrm{t}$ o pr esident) a nd $\mathrm{f}$ orm of government (monarchy to r epublic), but to c onvert a s lave-holding s ociety into one where all men and women, regardless of race, were free and agents unto themselves. H e wanted a free peasantry in place of a plantation ar istocracy, s trengthened ties $\mathrm{w}$ ith the en tire Trans-Atlantic world and free trade. In addition, Chirino and his partisans wanted to do away with an imposed state religion (Catholicism), and promote a pluralism of beliefs based on African, European and Native American syncretism, as was practiced in the cumbes, then serving as prototypes of the envisioned new world where "Liberté, Égalité, Fraternité" would be the guiding stars.

This chapter demonstrated that while the Afro-Zulians may not have been at the eye of the Trans-Atlantic r evolutionary s torm, they c ertainly were c aught up i $\mathrm{n}$ i ts more de vastating winds. T herefore, de spite be ing buffeted b y e vents throughout the T rans-Atlantic w orld, the

\footnotetext{
${ }^{76}$ Thomas Reinhardt, "200 Years of Forgetting: Hushing up the Haitian Revolution,” Journal of Black Studies, 35:4 (March 2005), 251.
} 
Afro-Zulians resisted the most tumultuous effects and held on. They survived and prospered in communities of their own making on the southern shores of Lake Maracaibo. 


\section{CHAPTER SIX}

\section{THE AFRO-ZULIANS}

This dissertation set out to ascertain the ethnogenesis and historical linkages of the blacks in the Sur del Lago with societies in Africa as well as other cultures of the Trans-Atlantic world, examined within a case study of those Angolans brought to the Sur del Lago Maracaibo in 1722 by the Basque-French Captain Juan de Chourio, and following the descendants of these Africans up until the declaration of Venezuelan independence from Spain in 1811. The ancestors of these blacks es tablished the $\mathrm{n}$ ucleus of $\mathrm{w}$ hat $\mathrm{b}$ ecame a s ignificant co ntingent of the co ntemporary Afro-Zulians.

\section{Emergence of an Afro-Zulian Community}

What was discovered is that like other blacks in the Diaspora, the Afro-Zulians strove to attain self-conscious dignity and respect. The Afro-Zulians successfully resisted the pressures to lose their identity through total assimilation into the Venezuelan pardo melting pot. ${ }^{1}$ But while they are proud of their African heritage, they would not Africanize the rest of Venezuela. They are cognizant that $\mathrm{V}$ enezuela is a p olitical house $\mathrm{h}$ ammered together by many carpenters, and they are content $\mathrm{t}$ o ha ve $\mathrm{pl}$ ayed a s ignificant $\mathrm{r}$ ole $\mathrm{i} \mathrm{n}$ i ts $\mathrm{c}$ onstruction. $\mathrm{T}$ heir $\mathrm{s}$ urvival a nd

\footnotetext{
${ }^{1}$ Robert M. Jiobu, Ethnicity and Assimilation (Albany: S tate University of New York Press, 1988), 5, 6. In the context of this dissertation, Jiobu's definition of assimilation is applied, whereby it signifies the "blend of the culture and structure of one ethnic group with the culture and structure of another group." Assimilation, therefore, has two possible outcomes: F irst, the minority group lo ses its distinctiveness and becomes like the majority. And in the process, the majority group does not change; or second, both the ethnic and majority groups blend homogeneously, with each losing its distinctiveness, whereby a unique product results. This process is sometimes referred to as the "melting p ot." J iobu in dicates th at, "these c oncepts have th eir o rigin p artially in scientific th eory, $\mathrm{p}$ artially i n Utopian wish, a nd p artially in political id eology." Assimilation c an sometimes b e r eferred to a s a cculturation. Assimilation is, therefore, regarded as a cu ltural mechanism of acculturation. Hence, the revolutionary activity of the A fro-Zulians e ngendered a partial p olitical a ssimilation, while miscegenation of the A fro-Zulians with o ther ethnicities fostered a partial national and pardo acculturation/assimilation that continues to the present time.
} 
expansion provides a message of hope for other groups of the A frican Diaspora throughout the Americas and the Caribbean. ${ }^{2}$

If it is true that, in the final a nalysis, r evolution is ba sed on 1 and, then the case of the Afro-Zulians can b e c ounted a s uccess. In o rder to produce a community, feed, s helter and clothe themselves, the A fro-Zulians secured and developed their own lands in the Sur del Lago. While ideas and theories were important to the Afro-Zulians, what they primarily fought for was $\mathrm{a} b$ etter $\mathrm{w}$ ay o $\mathrm{f} 1$ ife $\mathrm{f}$ or $\mathrm{t}$ hemselves an $\mathrm{d} \mathrm{t}$ heir $\mathrm{d}$ escendants. $\mathrm{T}$ he $\mathrm{i}$ deas an $\mathrm{d} t$ heories $\mathrm{m}$ erely provided them with the intellectual tools to accomplish this formidable task. After all, people do not usually fight, and sometimes die, solely for ideas and theories unless they can see a light at the end of the tunnel, i.e. a superior way of life emerging from those ideas and theories. ${ }^{3}$ That the A fro-Zulians enjoyed control over s ubstantial tracts of 1 and in the S ur del Lago pe rmitted them, as a people of the Diaspora, to retain and develop a knowledge of their Angolan origins, resist enslavement in the cumbe, oppose racism and forge their own destiny within the emerging cultural and political mosaic that is Venezuela.

Geographical factors in the Sur del Lago also proved to be important. At the beginning of this research, all that was known about the towns of Bobures and Gibraltar were their colorful and tropical character, and that they were largely inhabited by Afro-Zulians who enjoyed playing and 1 istening $t$ o t he chimbangueles, or A ngolan $\mathrm{dr}$ ums, on $\mathrm{f}$ estive oc casions. W hat $\mathrm{t}$ he investigation revealed, in the previous chapter, was that these towns, situated on the southern extremes of Lake Maracaibo and serving as cumbes, were centers of resistance against the slave aristocracy, a nd la ter, th e c olonial a uthorities. $\mathrm{T}$ heir $\mathrm{r}$ elative $\mathrm{g}$ eographic is olation is $\mathrm{w}$ hat

\footnotetext{
${ }^{2}$ W. E. B. Du Bois, Souls of Black Folk (New York: Dover Publications, Inc., 1994), 2-3. This book was originally published in Chicago, A. C. McClurg and Company, 1903.

${ }^{3}$ Stokely Carmichael, "Pan-Africanism- Land and Power" in Modern Black Nationalism: From Marcus Garvey to Louis Farrakhan, ed. William L. Van Deburg (New York: New York University Press, 1997), 209.
} 
allowed their inhabitants to avoid the general patterns of acculturation and deculturation imposed on $\mathrm{m}$ ost ot her bl ack Venezuelans. $\mathrm{O} \mathrm{nt}$ his $\mathrm{f}$ orced $\mathrm{s}$ ituation, $\mathrm{M}$ agnus $\mathrm{M}$ örner $\mathrm{p}$ enned: "Furthermore, $t$ he ve ry c onditions of $t$ heir pa ssage a nd $t$ heir e xistence a s s laves $\mathrm{m}$ ade i $\mathrm{t}$ impossible for them to bring any artifacts and other property to the New W orld. U nder these adverse conditions, it is surprising that, after all, the slaves were able to exert such influence as they did upon folk religion, language, music, dances and agriculture in the Americas. If the form of migration and treatment had been somewhat more humane, there can be no doubt that their contributions would have been much more important." 4

Here the Afro-Zulians were able to hold on to their ethnic integrity more so than blacks in other regions of Venezuela, like the littoral abutting the Caribbean coastline, replete with its big cacao and sugar plantations. ${ }^{5}$ Unlike those areas under a tight Spanish grip, in the more remote areas of the $\mathrm{S}$ ur de 1 Lago, Afro-Zulians es tablished the $\mathrm{p}$ erfect $\mathrm{b}$ reeding grounds for s edition against the colonial a uthorities. In the cumbes of Bobures and Gibraltar, a s in other cumbes across Venezuela, maroons and $\mathrm{N}$ ative Americans came together to organize and fight against their common foes: the white enslavers and Spanish rule. W ith regard to zambo leadership in Venezuelan revolutionary movements, Mörner notes: "In one way or another faint echoes of the French $\mathrm{R}$ evolution, or, $\mathrm{r}$ ather, $\mathrm{i}$ ts s equel in $\mathrm{H}$ aiti, $\mathrm{r}$ eached $\mathrm{t}$ he $\mathrm{S}$ panish $\mathrm{A}$ merican $\mathrm{m}$ asses. In Coro, Venezuela, José Leonardo Chirino, a free zambo, made himself leader of a slave uprising with the aim of introducing 'the Law of the French."”6

Therefore, within the confines of the cumbes a revolutionary ideology was able to take hold among the Afro-Zulians and others finding refuge there. Additionally, the cordillera of the

\footnotetext{
${ }^{4}$ Magnus Mörner, Race Mixture in the History of Latin America (Boston: Little, Brown and Company, 1967), 1718.

${ }^{5}$ Carlos Esteban Deive, Dominican Cultures, 90.

${ }^{6}$ Ibid., 79-80.
} 
Andes fronting the Sur del Lago inland to both the east and south served to isolate the region, and au gmented the defense of both B obures and $\mathrm{G}$ ibraltar. $\mathrm{T}$ his $\mathrm{w}$ as a nother factor that $1 \mathrm{ent}$ itself $\mathrm{t}$ o ha lting t he pr ocess of de culturation a mong the A fro-Zulians $t$ hrough $\mathrm{t}$ he $\mathrm{i}$ nfusion, maintenance and $\mathrm{f}$ ostering o f A ngolan Imbangala c ulture a mong t hem. In $\mathrm{r}$ esisting deculturation, Chourio's A fricans and their de scendants m oved in di rections that he lped them develop as a separate and distinct community within V enezuela. This w as the result of those historic forces that $\mathrm{w}$ orked a gainst $\mathrm{t}$ he i ncessant pus $\mathrm{h} f$ or $\mathrm{d}$ eculturation on $\mathrm{t}$ he part $\mathrm{o} f \mathrm{t}$ he European colonists and their descendants. T he Afrocentric theoretical construct central to this study acknowledges $t$ hat $t$ he A fro-Zulians s till maintained a s ignificant s emblance o f th ose fundamentals such as culture, ethnicity, language and religion that linked them to the Imbangala peoples of Angola.

\section{Trans-Atlantic Connections}

This dissertation also served to augment the connections made by the Afro-Zulians with the greater Trans-Atlantic world: the Basques, the Dutch, the English, the indigenous peoples, the Portuguese, the Spanish, as well as Africans and others of African descent. ${ }^{7}$ In this regard, the case of Juan de Chourio provided the link with all of these cultural groups. With the Basque connection, Chourio's genealogy w as thoroughly examined, thereby providing insight not only into his motivations for becoming involved in the A frican slave trade, but the often overlooked contributions m ade b y t he B asque pe ople generally i n he lping t o de velop t he $\mathrm{N}$ ew $\mathrm{W}$ orld. Through C hourio's c ase, linkages in the s lave trade were a lso probed. It is unde rstood, for example, that Chourio's father leveraged his influence with a French king sitting on the Spanish throne in order to obtain a diplomatic post in the Netherlands, and that Juan de Chourio, in turn,

7 The Afro-Zulians, for e xample, share in $\mathrm{t}$ he Afro-Venezuelan d evelopment of religious syncretism, the establishment of maroon settlements and the emergence common fronts against slavery, and later the manifestations of racism in Venezuelan society, both overt and imbedded. 
parlayed alliances gained among the Dutch to establish initial slaving operations on the island of Curaçao under the auspices of the French Guinea Company. And after 1713 and the signing of the Treaty of U trecht, e specially, all of th is transpired under the $w$ atchful e yes of the B ritish, enjoined to enforce their monopoly granted over slave trafficking operations in the Caribbean.

By $1722, \mathrm{t}$ he British grip ove $\mathrm{r}$ the $\mathrm{C}$ aribbean was tightening. $\mathrm{W}$ hereas the $\mathrm{S}$ panish colonists in Venezuela and throughout the region in need of African manual labor for their mines and plantations c ould no longer accept the importation of s laves from any agent ot her than a British one, the once inter-Caribbean source of s econd and third generation blacks was drying up. This trafficking was reduced to the realm of contraband trade. This forced Chourio and the French Guinea Company, as well as other asientos, to look back to Africa in order to obtain the required slaves.

This is w hat br ought $\mathrm{C}$ hourio to the $\mathrm{C}$ abinda Coast in Central W est Africa, to a port tenuously controlled by the French in an area predominantly under the visage of the Portuguese. It $\mathrm{w}$ as he re that $\mathrm{t}$ he Basque-French captain $\mathrm{m}$ ay have $\mathrm{f}$ irst encountered $t$ he Italian $\mathrm{C}$ apuchin missionaries, and hence the Imbangala. As the Capuchin fathers were a llowed to proselytize among the interior peoples of Angola and the Congo, and w ere actually qui te good at it, they found strange partners in the fierce Imbangala warriors. At various times in the early Portuguese incursions i nto the $\mathrm{C}$ entral $\mathrm{A}$ frican i nterior, Luso-Imbangala s trategic alliances w ere formed. These arrangements facilitated the westward expansion of the Imbangala out of the Luba-Lunda complex. T he Portuguese armed the Imbangala with European weapons, and this allowed the Imbangala to rapidly expand their territorial influence throughout the interior, but it $\mathrm{w}$ as not without a cost. A s a consequence, they had to turn over the majority of captured slaves to the Portuguese and accept Christian evangelization as provided by the Capuchins. They were also 
required to provide military de tachments to fight on be half of the Portuguese in other parts of their worldwide empire. These Luso-Imbangala fighters were known as the guerras pretas, and proved particularly effective in the conquest of B razil, ridding that c ountry of Dutch us urpers and $\mathrm{r}$ ebellious indigenous pe oples. ${ }^{8}$ Knowledge of the guerras pretas spread throughout the known world.

Chourio had to find a way to take advantage of this information and optimize his short presence in Africa, for he realized that his profitable days as an asentista were coming to a quick close. He needed to transition out of his role as a slave trafficker and get a piece of the action in the profitable cacao business. He faced several obstacles in this regard, however. First, most of the be st 1 and s uitable for $\mathrm{c}$ acao on $\mathrm{t}$ he $\mathrm{S}$ panish $\mathrm{M}$ ain ( mainland $\mathrm{c}$ oast of $\mathrm{t}$ he $\mathrm{S}$ panish e mpire around the Caribbean Sea), was in the highly developed littoral. Purchasing this land would be too cost prohibitive. Second, there was some choice property that could be developed, but it was in the areas south of Maracaibo and infested with bands of the hostile Motilones. And third and lastly, there was the matter of circumventing the British slave trade monopoly.

Taking all of $\mathrm{t}$ hese $\mathrm{m}$ atters $\mathrm{i}$ nto a ccount, $\mathrm{C}$ hourio $\mathrm{r}$ easoned $\mathrm{t}$ hat establishing $\mathrm{c}$ acao plantations in the Province of Maracaibo was his best option. He could undertake this enterprise based on the Spanish king's desires to reduce the Motilones and evangelize them in the process. With this in mind, he petitioned the king for a royal decree that granted him the authority to introduce a $\mathrm{C}$ apuchin mission i nto $\mathrm{t}$ he $\mathrm{z}$ one, engage $\mathrm{t}$ he Native American popul ation a nd suppress any rebellious among them, as well as to take whatever actions he deemed necessary to accomplish these aims. Hence, following the king's issuance of the cédula real, the introduction of his own contingent of the guerras pretas, along with a sufficient number of accompanying

\footnotetext{
${ }^{8}$ Mattos, "Black Troops," 15-16.
} 
slaves, was accomplished in 1723 , or close to it, plus or minus one year. ${ }^{9}$ In this endeavor of Chourio, the infusion of many Trans-Atlantic cultures found its fulfillment.

\section{Assimilation of Afro-Zulians in the Venezuelan Nation State}

This dissertation also demonstrates that Afro-Zulians assimilated into Venezuelan history from its $\mathrm{v}$ ery beginnings th rough th eir $\mathrm{d}$ irect $\mathrm{p}$ articipation in th ose $\mathrm{p}$ olitical a nd $\mathrm{s}$ ocial movements that led to the formation of the first republic. Throughout the formative years of 1722 through 1811, this dissertation highlights some areas of Afro-Zulian assimilation into what has $\mathrm{u}$ ltimately emerged as the $\mathrm{V}$ enezuelan $\mathrm{n}$ ation-state. $\mathrm{O}$ ver $\mathrm{t}$ ime, $\mathrm{V}$ enezuela $\mathrm{h}$ as b ecome a nation peopled by many groups from diverse ethnic and racial backgrounds, including the AfroZulians. A s not ed b y M örner a nd ot hers, a $11 \mathrm{~V}$ enezuelan bl acks $\mathrm{w}$ ere galvanized b y $\mathrm{t}$ he French/Haitian-inspired events that transpired on the Coro peninsula in the short-lived revolution of Chirino. ${ }^{10}$ This provided solidarity with the overarching struggle of all A fro-Venezuelans, in addition to an incorporation into the forthcoming Bolivarian Revolution, which would consume the active participation of all ethnic and social classes except the peninsulares.

The A fro-Zulians, then, were part of a true revolution that was Trans-Atlantic in scope. British historian J. B. Trend, a biographer of Simón Bolívar, made the following comments in this regard:

The revolutionary movement in Venezuela began in 1795 with a rising in Coro, a town some way from the capital (Caracas) and always in opposition to it. Serious outbreaks had already taken p lace in New Granada (present day Colombia) and Peru. On this occasion the causes of the revolt were social rather than political, although the influence of France and the United States is not difficult to detect. Negroes and mulattoes, with whom many pardos and a few whites were secretly in $t$ ouch, pr oclaimed w hat $t$ hey c alled ' the 1 aw of t he F rench:' a $r$ epublican

\footnotetext{
${ }^{9}$ Chiossone, Diccionario Toponímico, 490.

${ }^{10}$ Mörner, Race Mixture, 79-80.
} 
government, freedom for s laves, reduction of taxes. T he rebels w ere o vercome without difficulty and punished with the barbaric severity of the age. ${ }^{11}$

The events at C oro also served as a catalyst for yet more revolutionary stirrings in the Venezuelan black community. J ust two years later in nearby La Guira, Manuel Gual, a retired Spanish army officer, together with José María España, the owner of a large hacienda, advocated the formation of a r epublic that w ould incorporate pe ople of all races on an equal footing. ${ }^{12}$ These men, calling for equality, liberty and harmony among all Venezuelans, were also inspired by the $r$ hetoric of the F rench R evolution (1789). T hey made a conscious de cision to r ecruit blacks ( freed or s lave), pardos, poor w hites, 1 aborers a nd s mall s hopkeepers i $\mathrm{n}$ a w ar for independence. They promised to abolish black slavery, do a way with Native American tribute, and to establish a free trade zone throughout the Americas. To rally the people to their cause, these revolutionaries invoked the newly formed United States of America, but unfortunately they received ne ither he lp no $\mathrm{r}$ e ncouragement from the young $\mathrm{c}$ olossus $\mathrm{t} \mathrm{o}$ the nor th. A 11 of this proved to be too much for some of the big Creole property owners, who collaborated with the Spanish a uthorities to crush the r ebellion in i ts infancy. But as conditions w ould continue to deteriorate, cooler minds like Miranda and Bolívar would come to see the wisdom in bringing blacks onboard in the revolutionary struggle.

As the case of Gual and España so aptly illustrates, once Chirino and his partisans rose up in Coro, the spirit of revolution could not be contained within Venezuela. Therefore, despite the small dur ation of $\mathrm{t}$ he Coro $\mathrm{r}$ ebellion, $\mathrm{i} \mathrm{t} w$ as $\mathrm{s}$ ymptomatic of , a nd pe rhaps $\mathrm{t}$ he ke $\mathrm{yt} \mathrm{o}$, understanding the insurrectionist ferment gripping the entire Trans-Atlantic world at the end of the $e$ ighteenth a nd $b$ eginning of $t$ he ni neteenth $c$ entury. It $w$ ould appear $t$ hat $n$ either $t$ he

\footnotetext{
${ }^{11}$ J. B. Trend, Bolivar and the Independence of Spanish America (London: Hodder a nd S toughton for English Universities Press, 1946), 59.

${ }^{12}$ Haggarty, Venezuela: A Country Study, 50.
} 
American, F rench or Latin A merican revolutions can viewed as singular ev ents. They are all interconnected a s one $\mathrm{c}$ omprehensive $\mathrm{T}$ rans-Atlantic $\mathrm{r}$ evolution. ${ }^{13}$ Taken i $\mathrm{c}$ ontext, this revolutionary age began with the American Revolution in 1776, continued with the slave revolts that erupted in Saint-Domingue ( the F rench colony that became Haiti with its independence in 1804), a nd concluded $w$ ith the prolonged s truggle of the S panish A merican c olonies to free themselves from the grip of Spain, most of these having done so by the mid-nineteenth century. Following this timeline, we can set Venezuela's course to real revolution as beginning at Coro. This would place it after the start of the black insurrections in Saint-Domingue but preceding the work of Miranda and Bolívar. Its true s ignificance is that it fixed bl acks in the va nguard of revolution in Venezuela, and this included those of Angolan descent in the S ur del Lago. The Afro-Zulians, therefore, sealed their r evolutionary testament to V enezuelan hi story $w$ ith their blood. No further proof of assimilation was required.

Another $\mathrm{f}$ actor $\mathrm{f}$ acilitating a $\mathrm{p}$ artial a ssimilation, a t le ast, $\mathrm{w}$ as th at of mestizaje, or miscegenation. The infusion of European and Native American blood with that of A fro-Zulian peoples has forced them to try and r edefine their ow $\mathrm{n}$ identity w hile de aling $\mathrm{w}$ ith s ocial and sexual c onflicts, pow er, culture, the law and interpersonal relationships on a vast scale. E ven free blacks continued to suffer various forms of discrimination following Venezuela's de clared independence from Spain. As late as 1815, for example, the Captain-General of Venezuela, José Ceballos, was shocked to discover the extent that racial discrimination still flourished in Caracas. He mused that not only were full-blooded A fricans excluded from "all municipal positions and other honorable occupations and distinctions, from entrance in some religious congregations and brotherhoods," but "even from social contact with the white class. They would not approach the persons or houses of the whites without paying the same or greater respects to those paid or due

\footnotetext{
${ }^{13}$ Langley, Americas in the Age of Revolutions, 2.
} 
to public authority." 14 Clearly then, losing an African identity through intermarriage with nonblacks could have been viewed as a measure of upward social mobility. Mörner, the authority on race issues in Spanish Latin America, also states that it was not uncommon for peoples of color in the la te colonial era to p urchase a gracias al sacar, or "honorary whiteness certificate."15 Therefore, in c onsideration of this socializing and underlining E urocentric pr essure, it is qui te amazing that a core unassimilated African contingent still remains in Zulia State, to carry on the legacy of New Africa in the Sur del Lago.

\section{Afrocentric Culture}

The emergence of a New A frica in the Sur del Lago, a community of, by and for the Afro-Zulians, largely depends on the formation of Afrocentric cultural constructs. In this regard, the role of cultural elements like music and religion were significant in helping to discover and investigate $\mathrm{t}$ he Angolan or igins of $\mathrm{t}$ he $\mathrm{A}$ fro-Zulians, $\mathrm{t}$ hus $\mathrm{r}$ einforcing $\mathrm{t}$ heir $\mathrm{A}$ frocentric perspective. $\mathrm{C}$ ultural themes like m usic a nd religion take on a dded importance when v iewed from the practice of A frocentricity, which then serves as a transforming agent. M.K. A sante believes $\mathrm{t}$ hat $\mathrm{t}$ he $\mathrm{A}$ frocentric pa radigms pe rmit a $11 \mathrm{t}$ hings ol $\mathrm{d}$ to be come ne $\mathrm{w} .{ }^{16}$ Therefore, African and African-derived music and religion facilitate societal transformations in the lives of the A fro-Zulians, w hose a ttitudes, be liefs, va lues a nd ul timately, be haviors, w ere i nfluenced through the resurrection of Angolan musical and religious forms.

In s ocieties with a s carcity of w ritten s ources, hi story is pa ssed on $t$ hrough a rt, s ong, dance, the telling of stories and the enactment of ritual. This dissertation examined the research of La Universidad de Zulia professor, Juan de Dios Martínez Suarez, who de dicated his life to the $\mathrm{c}$ ollection a nd di ssemination of obj ective i nformation a bout t he A ngolan or igins a nd

\footnotetext{
${ }^{14}$ Mörner, Race Mixture, 65.

${ }^{15}$ Ibid., 64.

${ }^{16}$ Asante, Afrocentricity, 3.
} 
characteristics of the drums, music, and dances associated with the Sur del Lago communities of San José, Gibraltar, Palmarito and Bobures in the Sucre Municipality, ${ }^{17}$ as well as the emergence of new forms of religious syncretism based on the fusion of Roman Catholicism (San Benito), Central A frican orishas (principally A jé), a nd i ndigenous m yth (Mucúchies). ${ }^{18}$ Martínez' research has i ndicated $\mathrm{t}$ he ex istence of an thropological an $\mathrm{d} l$ inguistic ties to th ese $\mathrm{v}$ arious cultural themes with specific ethnicities in Angola, placing an emphasis on the Imbangala. This work continues where Martínez' left off. It provides a plausible historical linkage with the Sur del Lago c ommunities and the Imbangala th rough tracing the commercial trading activities of Juan de Chourio.

The $\mathrm{r}$ esuscitation of these A ngolan m otifs a mong the A fro-Zulians $\mathrm{c}$ ontributes t $\mathrm{o}$ the constructive efforts of the people in creating a symbolic life. The introduction of this A frican mythos helps the Afro-Zulians to discover the values of a spiritual, traditional and even mystical rhetoric that will serve them well in confronting the conforming pressures that a Eurocentric and increasingly technology-oriented society has imposed, and will continue to impose, upon them. Myth is imp ortant to A fro-Zulians b ecause it $p$ ermits th em to $s$ ee th emselves a s a gents of destiny, rather than vi ctims of circumstance. It defines their historic struggle and reinforces a true A frocentric id entity, fraternity and even a sense of nationhood. M. K. A sante articulated that: "We are, as the continental A fricans would teach us, and as we once knew, one with the environment. We have leaped from the environment, the same substance; the cells of the human bodies are of the same essence as the cells of trees and plants. We are quite honestly not humans separated from other matter, but, more correctly as the physicists now understand, of the same

\footnotetext{
${ }^{17}$ Martínez Suárez, Chimbángueles.

${ }^{18}$ Martínez Suárez, San Benito.
} 
nature. W ithin this context, myth is important as an organizing principle in the area of human discourse." 19

The pe rpetuation of a $\mathrm{n}$ A ngolan/Imbangala mythos a mong t he A fro-Zulians a 1so provided the impetus for them to resist enslavement and w ork for the liberation of themselves and their A fro-Venezuelan brothers and sisters. For example, most of Chirino's revolutionary cadre in W estern V enezuela s elf-identified a s A ngolans. In a ddition, the or ganization of the cumbes was consistent with that of the ki-lombos of the Imbangala and the quilombos of the Luso-Imbangala guerras pretas, ${ }^{20}$ even to the very es tablishment of perimeter defenses and the internal 1 ayout of $\mathrm{t}$ he maroon vi llage. ${ }^{21}$ There $\mathrm{w}$ as al so $\mathrm{t}$ he $\mathrm{t}$ radition $\mathrm{i} \mathrm{n} \mathrm{V}$ enezuela an $\mathrm{d}$ throughout $\mathrm{t}$ he $\mathrm{C}$ aribbean of $\mathrm{r}$ unaway bl acks $\mathrm{j}$ oining up $\mathrm{w}$ ith contrabandistas, f reebooters, pirates and ot hers ope rating a gainst the interests of the $\mathrm{S}$ panish $\mathrm{C}$ rown since the da ys of the práctico. $^{22}$

Thus, the Afro-Zulians, like other A fro-Venezuelans, fought when necessary against the evils foisted upon them by Spanish colonial administrators and slave masters. And as the day of Venezuelan $\mathrm{i}$ ndependence $\mathrm{d}$ rew ev er cl oser, the A fro-Zulians, a long w ith ot her A froVenezuelans, al igned themselves $w$ ith s undry $\mathrm{p}$ arties $\mathrm{p}$ artial t $\mathrm{o} b$ oth $\mathrm{t}$ he $\mathrm{F}$ rench an $\mathrm{d} \mathrm{H}$ aitian revolutions. $^{23}$ Try as they did, the Spanish colonial authorities and slave masters tried to limit access to information about these revolutionary movements in Europe and the Caribbean. The Haitian revolution, particularly, struck fear in the very core of their beings, as the slavers could never fitfully sleep, not knowing when their slaves would rise up and slash them to pieces with a machete. $D$ uring the $\mathrm{c}$ ourse of i nvestigation for this di ssertation, $i \mathrm{t} w$ as di scovered that the

\footnotetext{
${ }^{19}$ Asante, Race, Rhetoric and Identity: Architecton of Soul, 152.

${ }^{20}$ Mattos, "Black Troops," 15, 16.

${ }^{21}$ Bracho Reyes, "El culto de San Benito en el Sur del Lago," 49-50.

${ }^{22}$ Cohen, "Smuggling in Eighteenth Century Venezuela," 4-5.

${ }^{23}$ Brito Figueroa, 30 Ensayos.
} 
insurrection of $\mathrm{J}$ osé Leonardo $\mathrm{C}$ hirino e xercised $\mathrm{t}$ he $\mathrm{m}$ ost pr ofound i nfluence on all A froVenezuelans, and Chirino is also considered, along with Manuel Gual, José María España, and Francisco de Miranda, a precursor of Simón Bolívar and his valiant and successful transnational revolution across the northern tier of South America. Much information was gleaned concerning Bolívar and blacks, a s well as A fro-Venezuelans generally in the pe riod of $1811 \mathrm{t}$ hrough the abolition of slavery in Venezuela in 1854. However, this was beyond the scope of this work and remains open as the subject for further research and publication.

\section{Conclusions}

Having be en $t$ ransported $t$ housands of $m$ iles across $t$ he $s$ ea from $t$ heir hom es in $t$ he Angolan interior, so far from their families and established social networks, the blacks in the Sur del Lago qui ckly unde rtook $m$ easures $t$ o i ntegrate $t$ hemselves $w$ ithin $t$ he e xtant $\mathrm{c}$ olonial Venezuelan s ociety, yet s et a bout to create a c ommunity o f their ow $\mathrm{n}$. U nder c onditions of servitude or freedom, the A fro-Zulians w ere successful in forging a new society in the Sur del Lago $\mathrm{M}$ aracaibo. $\mathrm{T}$ his di ssertation, in hi ghlighting the emergence of a $\mathrm{N}$ ew $\mathrm{A}$ frica on $\mathrm{t}$ he southern shores of Lake Maracaibo, added a new area of research for students of the Diaspora. This dissertation also assures that the memory of those 600 Africans brought to the Province of Maracaibo b y J uan de C hourio, a nd their de scendants, w ill not be 1 ost t o the hi story of the worldwide diffusion of black people.

From the b eginning of s ettlement, the A fro-Zulians c arved out a $\mathrm{n}$ i mportant ni che for themselves in co lonial Venezuela, s erving as guerras pretas in s ubduing hos tile i ndigenous populations and carving out zones for future agricultural production and cattle herding. While many cultures interacted in the Sur del Lago, the area maintained a largely Afrocentric character mostly due to the strong Imbangala influence exercised by Chourio's original black contingent. 
During the late eighteenth and early ni neteenth c entury, many fugitive blacks from throughout the region found their way to the cumbes in the Sur del Lago. The interaction of the blacks in these $\mathrm{communities} w$ ith local indigenous popul ations, mulattoes, pardos and renegade whites, also allowed for greater access to, and connections with, the larger Trans-Atlantic world. Over time, th is $\mathrm{f}$ acilitated Afro-Zulian $\mathrm{i}$ dentification $\mathrm{w}$ ith, a nd $\mathrm{p}$ articipation $\mathrm{i} \mathrm{n}, \mathrm{r}$ evolutionary movements then sweeping Europe, the Caribbean and the Americas.

Because of Chourio's black contingent and its ability to hold on to and transmit sundry elements of Angolan culture and values, the Afro-Zulians have been rescued from an invisibility and $m$ arginality of ten a ffixed to ot her gr oups of the D iaspora in Latin America. The AfroZulians contributed to the evolution of Venezuela as a free and democratic state. Through the centuries, the blacks of the Sur del Lago were active participants in the construction of their own communities and the forging of a true Afro-Zulian identity. 
APPENDIX A: CITI Training Certification attained by Raymond A. Keller, II, on S eptember 16, 2008 in compliance with dealing with human subjects. 
APPENDIX B: Social $\mathrm{G}$ roups b y $\mathrm{C}$ aste and Race that $\mathrm{F}$ ormed $\mathrm{S}$ panish $\mathrm{C}$ olonial $\mathrm{S}$ ociety in Venezuela during the period of 1722-1811.

The following are presented in their order of societal precedence. They are adapted from pages 29 and 30 of Zamora, H., et al. Estudios Sociales. Caracas: Departamento de Producción de Colegial Bolivariana, C.A., 1998.

\section{SOCIAL STRATIFACTION OF VENEZUELAN COLONIAL SOCIETY}

BLANCOS PENINSULARES: Born in Spain. These possessed all of the high posts in the royal administration. They were archbishops, bi shops, captains general, bur eaucrats, etc. G enerally, they staffed nearly all of the higher public employee positions.

BLANCOS C RIOLLOS (Creoles): B orn i n V enezuela. They were $\mathrm{d}$ escendents of $\mathrm{t}$ he conquistadores and therefore owners of vast tracts of land. They were the true dominant, landed aristocracy. T hose that ow ned $\mathrm{g}$ reat $\mathrm{m}$ ansions a nd e states $\mathrm{w}$ ere know $\mathrm{n}$ a s mantuanos, or in popular terminology, "grandes cacaos." They also regulated the local constabulary through the office of the city hall and exercised dominion in most of the municipal assemblies. Only those who owned land, slaves, or hired hands to work vast cattle ranches could sit on these assemblies. It was a privileged group and within it resided the wise, educated and the wealthy.

BLANCOS CANARIOS: Originated in the Canary Islands. These were laboring white persons (tradesmen) and merchants. They did not occupy high positions in public administration nor did they possess vast sums of money. For the most part, they lived on the outskirts of the cities.

PARDOS: They were the majority population group in the $18^{\text {th }}$ century. They were the racial product of intense e thnic $\mathrm{m}$ ixing that t ook $\mathrm{pl}$ ace throughout the colonial e poch. T here w ere pardos (browns) of $\mathrm{w}$ hite a nd i ndigenous $\mathrm{c}$ alled mestizos, a nd yet o thers of bl acks a nd indigenous $\mathrm{c}$ alled zambos. T hose bor $\mathrm{n}$ in varying de grees be tween these $\mathrm{t}$ wo a forementioned groups received various names like tercerón, cuarterón, salto atrás, tente en el aire, sambajo, quinterón, etc. There were more than 100 such classifications, and by the start of the nineteenth century, the simple but more comprehensive term of pardo came into general u se. They were dedicated to various trades such as carpentry, iron working, tailoring, shoe making, etc. Socially, they $\mathrm{w}$ ere di scriminated a gainst $\mathrm{b}$ y $\mathrm{t}$ he $\mathrm{C}$ reoles, $\mathrm{w}$ ho $\mathrm{w}$ ould not pe rmit $\mathrm{t}$ hem $\mathrm{t} \mathrm{o}$ e nter i nto university s tudies or oc cupy any pos $\mathrm{t} i \mathrm{n} \mathrm{t}$ he $\mathrm{R}$ oyal $\mathrm{C}$ onsulate. $\mathrm{N}$ either $\mathrm{c}$ ould $\mathrm{t}$ hey $\mathrm{b}$ ecome ordained as priests. N evertheless, since 1797 they were admitted into schools of medicine and allowed to serve as doctors in various civilian and military capacities, but only because there was a lack of qualified white doctors.

INDIOS: $\mathrm{B}$ y the e nd o $\mathrm{fthe} 18^{\text {th }}$ century, ne arly all of the i ndigenous popul ation ha $\mathrm{d}$ be en conquered. Many lived in small towns as free individuals while others lived on mission grounds. Still o thers $\mathrm{p}$ referred to $\mathrm{d}$ istance th emselves $\mathrm{f}$ rom $\mathrm{S}$ panish $\mathrm{c}$ olonial $\mathrm{s}$ ettlements, $\mathrm{k}$ eeping to remote areas like jungle valleys or mountain tops. The indigenous population greatly diminished during $\mathrm{t}$ he $\mathrm{c}$ onquest a nd $\mathrm{c}$ olonization of $\mathrm{V}$ enezuela due $\mathrm{t} \mathrm{o}$ i ncessant warfare a nd bi ological agents introduced inadvertently by the Europeans, blacks and mulattoes. 
NEGROS: T hese were the pure blacks. T hey were generally found in conditions of s lavery, although $t$ here $\mathrm{w}$ ere $\mathrm{s}$ ome $\mathrm{w}$ ho $\mathrm{w}$ ere $\mathrm{f}$ reed o $\mathrm{r}$ even manumisos, $\mathrm{i}$.e. they $\mathrm{p}$ aid $\mathrm{f}$ or $\mathrm{t}$ heir ow $\mathrm{n}$ freedom. In any event, the blacks found themselves in the group considered the most socially inferior i $\mathrm{n} t$ he $\mathrm{c}$ olonial s ociety, and $\mathrm{h}$ ad $\mathrm{t}$ he most di fficult obs tacle i $\mathrm{n} t$ rying $\mathrm{t}$ o ove rcome imbedded racism at all levels. 


\section{APPENDIX C: ROMAN CATHOLIC MOTIVATIONS OF JUAN DE CHOURI}

Much of the wealth generated in the A mericas and elsewhere ultimately found its way back to Navarra, contributing to the construction of churches and other important buildings there. But a good deal of it remained in Venezuela as well, adding to the legacy and patrimony of the soon to emerge Bolivarian republic. J uan de Chourio, for example, is believed to have returned to the Basque country sometime in the mid-1740s, whence he commissioned an a nonymous artist to paint the Virgin Mary and Baby Jesus. This splendid piece of artwork, titled "Our Lady of the Rosary," is thought to be the oldest European painting extant in the contemporary Venezuelan town of Rosario de Perijá. According to legend, Chourio was quite a zealous Catholic ${ }^{24}$ and felt that the town he established would not be complete without a portrait of the Holy Mother and her child $\mathrm{J}$ esus on di splay in the ve ry $\mathrm{c}$ hapel that he ha $\mathrm{d}$ pr eviously erected there in the pl aza. Chourio arrived back in Perijá in $1748 \mathrm{w}$ ith the iconic painting. It is still venerated by devout Catholics from Venezuela and beyond. ${ }^{25}$

\footnotetext{
${ }^{24}$ In the document of Francisco de U garte dated 28 November 1757, we learn that the recently deceased Juan de Chourio had placed a military protective unit around the Capuchine Fathers, mostly Italian missionaries in the area of Perijá for its native inhabitants. This same Chourio also dispatched two permanent guards to the residence of the Capuchins to protect their persons and property. And all of this done was at his own expense, most likely with the assistance of the A fricans he kept under his supervision, rather than underselling them in accordance with the new British mandate and regulation of the slave trade. As noted in Chapter One, Chourio branded the contingent of 600 Africans to the Sur del Lago with his name, rather than sell them on the open market, whence he would receive a pittance. These Africans may have also been maintained by Chourio for work on the three cacao plantations he had purchased at bargain prices, due to the raids by Native American bands. The Capuchins were most touted for their massive conversion of Africans in the heart of Angola, and many Africans were noted as loyal, Christian aids to the European $\mathrm{c}$ olonists. $\mathrm{T}$ he I mbangala $\mathrm{c}$ hapter further e xplores these a nd o ther $\mathrm{F}$ rench an $\mathrm{d} \mathrm{P}$ ortuguese African connections.

25 Alberto $\mathrm{P}$ achano Nava, Himno a Nuestra Virgen del Rosario, http://www.perija.com/elcorreodelasierra/html/pachano.htm (27 April 2009) Pachano Nava, a local historian in the area of Perijá, also dedicated a prayer to Our Lady of the Rosary, which is recited by her devotees worldwide and published on the cited webpage.
} 
Figure C.1: Our Lady of the Rosary.

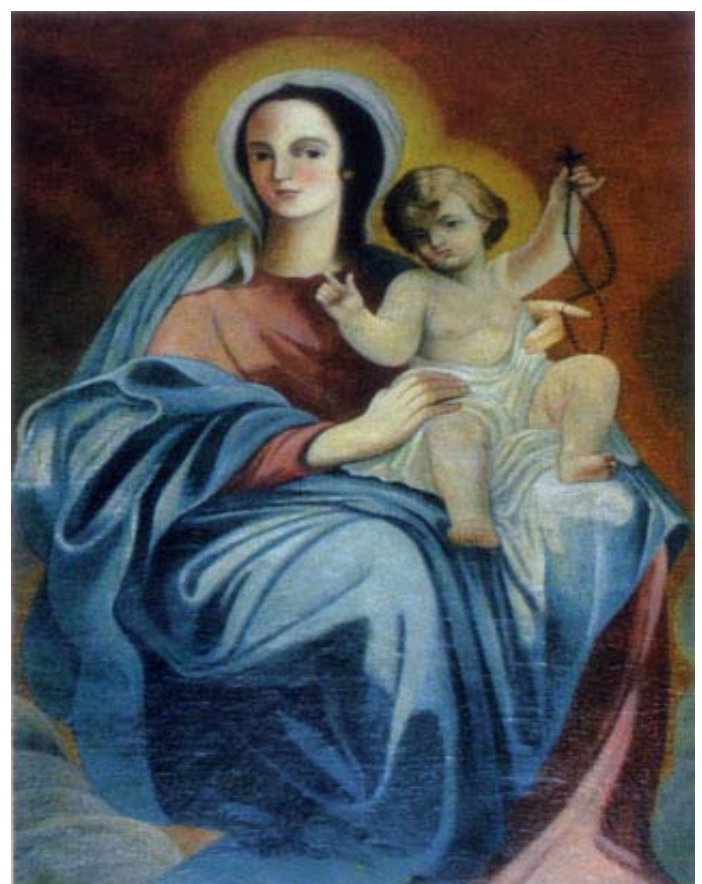

The pa inting, Nuestra Señora del Rosario (Our Lady of the R osary) is r eputed to h ave b een brought from the Basque country by Juan de Chourio as an addition to the Capuchin chapel at Perijá, Venezuela, in 1748.

Source: http://www.perija.com/elcorreodelasierra/html/pachano.htm 
APPENDIX D: Brito F igueroa, La Esctructura Económica, pa ge 362 ( map o f V enezuelan cumbes, 1550-1800), with major Afro-Venezuelan slave rebellions and insurrections.

Definitions for map:

alzamiento: uprising

cimarronera: fugitive slave settlement

conspiración: conspiracy or plot

cumbe: fugitive slave settlement

esclavo negro: black slave

insurrección: insurrection

rochela: fugitive slave settlement

sublevación: revolt

Map D.1: Map of Venezuelan cumbes

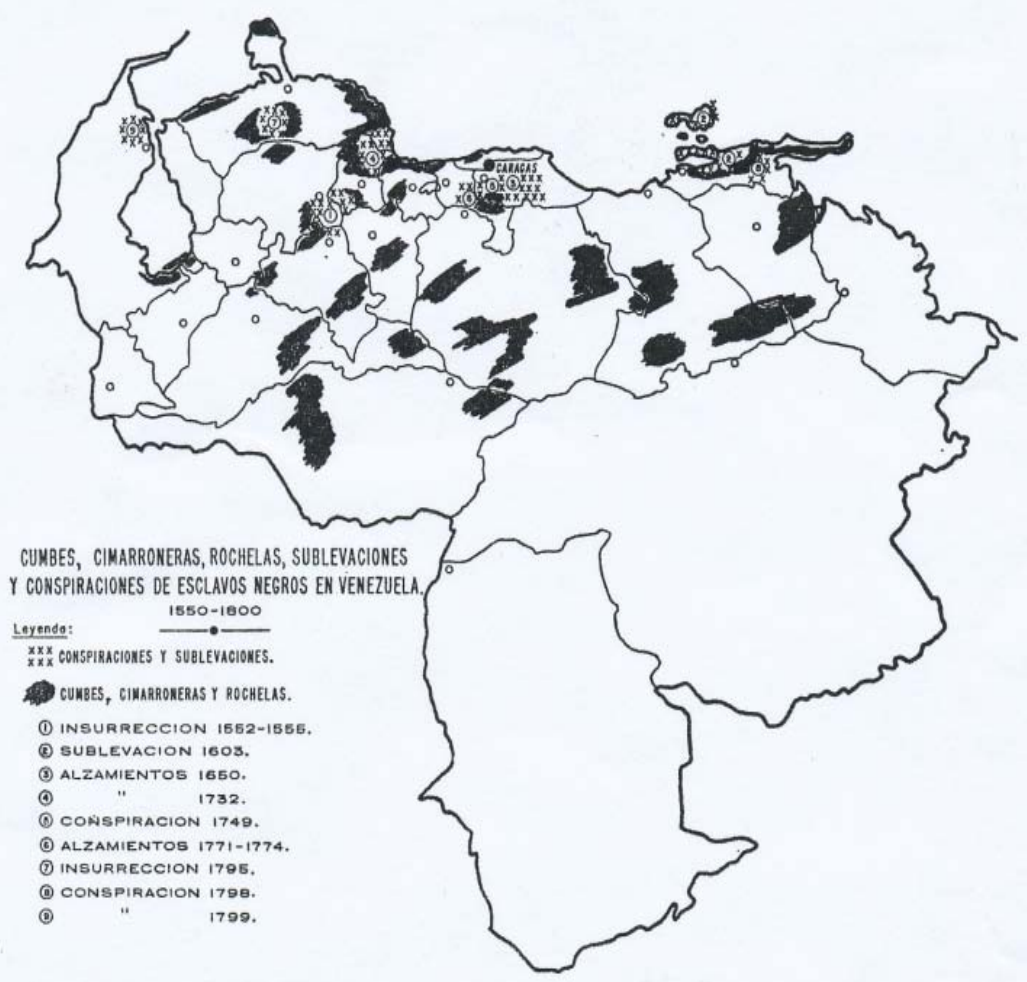




\section{BIBLIOGRAPHY}

\section{Primary Sources}

Angel $\mathrm{P}$ arra, Jesús. $\mathrm{E}$ lectronic c orrespondence $\mathrm{f}$ rom $\mathrm{C}$ hair, Department of $\mathrm{H}$ istory, La Universidad de Zulia, to author, 2 June 2010.

Cavazzi da $\mathrm{M}$ ontecucculo, $\mathrm{G}$ iovanni A ntonio. Istorica Descrizione de' tre regni Congo, Matamba ed Angola, 1665-1668, 2 vols. (Bologna: 1687, 2nd e d. 1690), e d.and trans. Padre Graciano Maria de Leguzano (Lisbon: Junta de Investigações do Ultramar, 1965).

Francisco de U garte to Jose $\mathrm{S}$ olis $\mathrm{F}$ olch de $\mathrm{C}$ ardona, $28 \mathrm{~N}$ ovember 175 7, A rchivo H istórico Nacional de Colombia (Ciudades de Venezuela), Catálogo R-3:110-113, Public Library, Mérida, Venezuela.

Mendes, Irmão A ntónio. Letter $\mathrm{t}$ o t he $\mathrm{F}$ ather $\mathrm{G}$ eneral, $9 \mathrm{M}$ ay 1563, i n A ntónio B rasio, Monumenta Missionaria Africana, 2 vols. (Lisbon: 1952-65), II: 509.

Miguel de Villanueva, S ecretary to the S panish King, to Captain Juan de Chourio, 27 O ctober 1735, A rchivo Histórico N acional de Colombia (Ciudades de Venezuela), Catálogo R 3:185-186, R-6:66-84, Public Library, Mérida, Venezuela.

Philip V to Juan de Chourrio (sic), 31 July 1722, Documentos del Archivo Histórico Nacional de Bogotá, Salón de la Colonia, Reales Cédulas, Tomo VII, fols. 739 r. - 740 r.

"Rapport su la législation politique que régit le Commerce de la France, a l'egard le l'Amérique Espagnole et de Colonies Étrangères en général," $2 \mathrm{~F}$ ebruary 1716, A rchives du Ministère des Affaires Étrangères, Mémoires et Documents, Amérique, Paris.

Royal $\mathrm{C}$ ommission at Maracaibo, findings in favor of $\mathrm{J}$ uan $\mathrm{C}$ hourio de Iturbide, $\mathrm{s}$ igned and sealed b y J oseph $\mathrm{M}$ oreno de $\mathrm{S}$ antisteban, $\mathrm{t}$ he publ ic s cribe a nd c lerk of $\mathrm{c}$ ourt, 5 September 1732. Archivo H istórico $\mathrm{N}$ acional d e C olombia (Ciudades d e V enezuela), Catálogo R-6:66-84, Public Library, Mérida, Venezuela.

Santana E zkerra, A lberto. E lectronic c orrespondence f rom D irector, B oise S tate U niversity Basque $\mathrm{S}$ tudies $\mathrm{P}$ rogram, $\mathrm{t}$ o a uthor a nd $\mathrm{P}$ atty $\mathrm{M}$ iller, $\mathrm{E}$ xecutive $\mathrm{D}$ irector of Basque Museum and Cultural Center at Boise, Idaho, 25 March 2009.

\section{$\underline{\text { Oral Sources }}$}

Antúnez Pirela, Cirilo, at San José, Zulia State, Venezuela, 27 December 2005.

Fall Mahkete, Kiva, at Morgantown, West Virginia, 26 January 2010.

Herrera Chourio, Deglis Atilano, at San Antonio, Zulia State, Venezuela, 31 May 2004. 
López, R oberto “Diken" Carlos, at the A fro-Asian Institute of the University of the A ndes in Mérida, Venezuela, 16 December 2005.

Miller, Patty, at Basque Cultural Center, Boise, Idaho, 13-19 June 2009.

Pineda, Ricardo, telephonically to editorial office, Panorama newspaper, Maracaibo, Venezuela, 27 June 2010.

\section{Secondary Sources}

\section{Books}

Acosta S aignes, M iguel. Vida de los esclavos negros en Venezuela (Valencia, V enezuela: Vadell Hermanos Editores, 1984).

Aizpurua, Ramón. Temas de historia colonial de Venezuela y del Caribe (Caracas: Universidad Central de Venezuela, 1966).

- Curaçao y la costa de Caracas: Introducción al estudio del contrabando de la provincial de Venezuela en tiempos de la compañía Guipouzcoana, 1730-1788 (Caracas: Biblioteca de la Academia Nacional de la Historia, Fuentes para la Historia Colonial de Venezuela \#222, 1993).

Arauz Monfante, Celestino Andrés. El contrabando holandés en el Caribe durante la primera mitad del siglo XVIII (Caracas: Biblioteca de la Academia Nacional de la Historia, 1984).

Arcila F arías, Eduardo. Economía colonial de Venezuela (México, D .F.: Fondo de C ultura Económica, 1946).

. Reformas económicas del siglo XVIII en Nueva España, $2^{\text {nd }}$ ed. (México, D.F.: Secretaría de Educación Pública, 1974).

Arellano Moreno, Antonio. Orígenes de la economía venezolana (Caracas: Universidad Central de Venezuela, 1982).

Asante, Molefi. Afrocentricity: The Theory of Social Change (Chicago: A frican A merican Images, 2003).

. Race, Rhetoric and Identity: The Architecton of the Soul (Amherst, Ne w Yo rk: Humanity Books, 2005).

Ascencio, M ichelle. San Benito: ¿Sociedad Secreta? (Caracas: U niversidad C entral d e Venezuela, 1976).

Bastide, Roger. Le Candomblé de Bahia (Rite Nagô), (Paris, Mouton, 1958).

. African Civilizations in the New World (New York: Harper and Row, 1971). 
Bauman, Janice and Leni Young. Guide to Venezuela (Caracas: Ernesto Armitano, 1981).

Birmingham, David. "African R esponse to Early Portuguese Activities in Angola," in Protest and Resistance in Angola and Brazil, ed. Ronald H. Chilcote (Berkeley: University of California Press, 1972).

Blet, Henri. France d'outre mer: L'oeuvre coloniale de la troisième république, 3 Vols. (Paris : B. Arthaud, 1950).

Blok, Anton. Honour and Violence (Cambridge: Polity Press, 2001).

Brito F igueroa, Federico. Las insurrecciones de los esclavos negros en la sociedad colonial venezolana (Caracas: Editorial Cantaelaro, 1961).

- Estructura Económica de Venezuela Colonial (Caracas: U niversidad C entral d e Venezuela, 1963).

. 30 Ensayos de Comprensión Histórica: Colección Historia 25 (Caracas: Universidad Central de Venezuela, Ediciones de la Biblioteca, 1997).

Cabral, Amilcar. Selected Speeches (New York: Monthly Review Press, 1973).

Carmichael, Stokely. "P an-Africanism- Land and Power," in Modern Black Nationalism: From Marcus Garvey to Louis Farrakhan, ed. William L. Van Deburg (New York: New York University Press, 1997).

Caro Baroja, Julio. Hora Navarra del XVIII (Pamplona, España: Editorial Gómez, 1969).

Cohen, W illiam B . French Encounter with Africans: White Response to Blacks, 1530-1880 (Bloomington: Indiana University Press, 1980).

Correia, J. Alves. A dilatação da fé no império portugués, 2 vols. (Lisbon, 1936).

Davidson, Alan and Tom Jaine. Oxford Companion to Food (Oxford: Oxford University Press, 2006).

Davidson, B asil. Black Mother: The Years of the African Slave Trade (Boston: A tlantic Monthly Press, 1961).

Deive, Carlos Esteban. "African Influence in Dominican Culture," in Dominican Cultures: The Making of a Caribbean Society, ed. Bernardo Vega (Princeton: Marcus Wiener, 2007). This book $\mathrm{w}$ as or iginally published in the S panish language in $1981 \mathrm{~b}$ y the $\mathrm{F}$ undación Cultural Dominicana, Santo Domingo, Dominican Republic. 
Diouf, Sylviane Anna and Sylviane Kamara. Servants of Allah: African Muslims Enslaved in the Americas (New York: New York University Press, 1998).

Dos S antos, Deoscoredes M . and Juana E lbein D os S antos. "Religión y cultura negra," in África en América Latina, ed. Manuel Moreno Fraginals (Paris: UNESCO, 1977).

Douglass, W illiam A . and J oseba Zuliaka. Basque Culture: Anthropological Perspectives (Reno: Center for Basque Studies, University of Nevada, 2007).

Du Bois, W. E. B. Souls of Black Folk (New York: Dover Publications, Inc., 1994). This book was originally published in Chicago, A. C. McClurg and Company, 1903.

Duffy, James. Portuguese Africa (Cambridge: Harvard University Press, 1959).

Ellis, A Ifred B urdon. Yoruba-Speaking Peoples of the Slave Coast of West Africa: Their Religion, Manners, Customs, Laws, Language, Etc. (London, 1894).

Emmer, P ieter. The Dutch in the Atlantic Economy, 1580-1880: Trade, Slavery and Emancipation (Brookfield, Vermont: Ashgate Publishing, 1998).

Essenfeld de Bruwer, Senta. La cara oculta del desarrollo (Caracas: Ediciones Monte Ávila, 1987).

Estrada, Rafael, et al, Estudios Sociales (Caracas: Ediciones Co-Bo, 1997).

Etxegoien, Juan Carlos. The Country of the Basques (Pamplona: XAMAR, 2001).

Feliciano Ramos, Hector R. El contrabando ingles en el Caribe y el Golfo de México, 17481778 (Sevilla: Publicaciones de la Excma. Diputación Provincial de Sevilla, 1990).

Fennell, Christopher C. Crossroads and Cosmologies: Diasporas and Ethnogenesis in the New World (Gainesville: University Press of Florida, 2007).

Ferry, Robert J. The Colonial Elite of Early Caracas (Berkeley: University of California Press, 1989).

García, Jesús “Chucho.” África en Venezuela (Caracas: Cuadernos Lagoven, 1990).

Gaston-Martin, Historie de l'Esclavage dans les Colonies Françaises (Paris: Presses Universitaires de France, 1948).

Goslinga, C. A. Los Holandeses en Venezuela (Caracas: A sociación Holandesa de Venezuela, 1992).

Grahn, Lance. The Political Economy of Smuggling: Regional Informal Economies in Early Bourbon New Granada (Boulder: West View Press, 1977). 
Helferich, G erard. Humboldt's Cosmos: Alexander von Humboldt and the Latin American Journey That Changed the Way We See the World (New York: Gotham, 2004).

Herr, Richard. Modern Spain (Berkeley: University of California Press, 1971).

Herrera Salas, Jesús María. El Negro Miguel y la primera revolución venezolana: la cultura del poder y el poder de la cultura (Caracas: Vadell Hermanos, 2003).

Hussey, Roland Dennis. Caracas Company, 1728-1784 (Cambridge: Harvard University Press, 1934.

James, C. L. R. The Black Jacobins: Toussaint L'Ouverture and the San Domingo Revolution (New York: Random House, 1963).

Jiobu, R obert M . Ethnicity and Assimilation (Albany: S tate U niversity of $\mathrm{N}$ ew Y ork P ress, 1988).

Johnson, Lyman L. and Matthew Restall, eds., Beyond Black and Red: African-Native Relations in Colonial Latin America (Albuquerque, University of New Mexico Press, 2005).

Joseph, Richard. Haiti (New York: Nelson Doubleday, 1959).

Kaplan, Irving. Angola: A Country Study, $2^{\text {nd }}$ ed. (Washington, District of Columbia: American University, 1979).

Karenga, M aulana. "From the Nguzo Saba (The S even P rinciples): $\mathrm{T}$ heir $\mathrm{M}$ eaning and Message," in Modern Black Nationalism: From Marcus Garvey to Louis Farrakhan, ed. William L. Van Deburg (New York: New York University Press, 1997).

Introduction to Black Studies (Los Angeles, California: University of Sankore Press, 2002).

Klooster, Wim. Illicit Riches: Dutch Trade in the Caribbean, 1648-1795 (Leiden: K ITLV Press, 1998).

Kurlansky, Mark. Basque History of the World (New York: Walker Books, 1999).

Labat, Jean-Baptiste. Nouvelle relation de l'Afrique occidentale, T. 4 (Paris, 1728).

Jane Landers, Black Society in Spanish Florida (Chicago: University of Illinois Press, 1999).

Langley, Lester D. The Americas in the Age of Revolution,1750-1850 (New H aven: Y ale University Press, 1998).

Liscano, Juan. La fiesta de San Juan el Bautista (Caracas: Monte Avila Editorial, 1973). 
López Bohórquez, Alí Enrique, ed. Manuel Gual y José María España: Valoración múltiple de la conspiración de La Guaira de 1797 (Caracas: Comisión Presidencial del Bicentenario de la Conspiración de Gual y España, 1997).

Lovejoy, Paul E. and David V. Trotman. Trans-Atlantic Dimension of Ethnicity in the African Diaspora (London: Continuum, 2003).

Márquez $\mathrm{C}$ arrero, Andrés. Introducción a la Emeritología: El caso especifico de las áreas indígenas del Estado Mérida (Mérida: Centro de Investigaciones Lingüísticas "Julio Cesar Salas,” La Universidad de Los Andes, 1986).

Martínez S uarez, J uan de D ios. Antecedentes y orígenes del Chimbángueles (Maracaibo: L a Universidad de Zulia, 1983).

- Como Bailar Chimbángueles: Colección Danzas Étnicas y Tradicionales No. 1 (Maracaibo: Fundación Ajé, 1991).

. El culto a San Benito de Palermo en Venezuela (Maracaibo: Cultura de la Universidad de Zulia, 1999).

Marx, Karl. El Capital, T. 1, 2 vol s. (México: Fondo de Cultura Económica, 1946). Original published in German as Das Kapital in1867.

McCloy, Shelby T. The Negro in France (Lexington: University of Kentucky Press, 1961).

Miller, Joseph C. Kings and Kinsmen (Oxford: Clarendon Press, 1976).

. Way of Death: Merchant Capitalism and the Angolan Slave Trade, 1730-1830 (Madison: University of Wisconsin Press, 1988).

Mörner, Magnus. Race Mixture in the History of Latin America (Boston: L ittle, B rown and Company, 1967).

Ndaywel è Nziem, "The political system of the Luba and Lunda: its emergence and expansion" (Chapter 20), in Africa from the Sixteenth to the Eighteenth Century, UNESCO General History of Africa, vol. 5, ed. B. A. Ogot (London: Heinemann, 1992).

Newitt, M alyn. Portugal in Africa: The Last Hundred Years (London: L ongman G roup, Limited, 1981).

Palmer, Colin A. Bondage Studies in Slavery and the Slave Trade (Madison: U niversity of Wisconsin, 1986).

Pélissier, René and Douglas L. Wheeler, Angola (New York : Praeger Publishers, Inc., 1971). 
Peñaloza Torres, Alexi. Mérida: Alcaldías del Estado Mérida y Entidades Culturales (Mérida, Venezuela: Gobierno del Estado Mérida, Dirección de Cultura del Estado Mérida, 1993).

Pérez, Berta. "Pantera N egra," in Blackness in Latin America and the Caribbean, vol. 1, e ds. Arlene Torres and Norman E. Whitten (Bloomington: Indiana University Press, 1998).

Pérez $\mathrm{J}$ ímenez, $\mathrm{M}$ arcos, $\mathrm{C}$ olonel a nd $\mathrm{P}$ resident of $\mathrm{t}$ he $\mathrm{R}$ epublic of Venezuela. A uthorized publication as a "souvenir," Inauguración de la estatua ecuestre del Libertador en Haití (Caracas: Imprenta Nacional, 1954).

Piñero, Eugenio. Town of San Felipe and Colonial Cacao Economies (Philadelphia: American Philosophical Society, 1994).

Pollak-Eltz, Angelina. La negritud en Venezuela (Caracas: Lagoven, 1992).

Purchas, Samuel. His Pilgrimage (London, 1613).

. His Pilgrimes (London, 1625).

Querexeta, Jaime de. Diccionario Onomastico y Heraldico Vasco (Bilbao: Biblioteca de la Gran Enciclopedia Vasca, Tomo I, 1970; Tomo II, 1971; and Tomo III, 1972).

Ravenstein, E. G. Strange Adventures of Andrew Battell of Leigh (London, 1901).

Reefe, T homas Q. The Rainbow and the Kings: A History of the Luba Empire to 1891 (Berkeley: University of California Press, 1981).

Restall, Matthew. "Black Slaves, Red Paint," introduction in Beyond Black and Red: AfricanNative Relations in Colonial Latin America, ed. M atthew R estall ( Albuquerque: University of New Mexico Press, 2005).

Robertson, W illiam S pence. France and Latin-American Independence (Baltimore: J ohns Hopkins Press, 1939).

Rout, J r., L eslie B . African Experience in Spanish America, 1502 to the Present Day (Cambridge: Cambridge University Press, 1976).

Rupert, Linda M. Roots of Our Future (Willemstad: Curacao Chamber of Commerce, 2002).

Saignes, Miguel Acosta. Vida de los esclavos negros en Venezuela (Valencia, Venezuela: Vadell Hermanos, 1984).

Sanson, Nicholas. L'Afrique et plusieurs cartes nouvelles et exactes et en divers traictés de géographie et d'historie (Paris, 1666).

Sartre, Jean Paul. Black Orpheus (Paris: Edition Gallimard, 1948). 
Super, John C. and Briane K. Turley, Religion in World History (New York: Routledge, 2006).

Sweet, James H. Recreating Africa: Culture, Kinship and Religion in the African-Portuguese World, 1441-1770 (Chapel Hill: University of North Carolina Press, 2003).

Thomas, Hugh. The Slave Trade: The Story of the Atlantic Slave Trade, 1440-1870 (New York: Simon and Shuster, 1997).

Thornton, J ohn K. "Religious and Ceremonial Life in the K ongo and Mbundu A reas, 1500 1700," in Central Africans and Cultural Transformations in the American Diaspora, ed. Linda M. Heywood (Cambridge: Cambridge University Press, 2002).

Tishkin, Joel E. “Central A frica: P eoples and States” (Chapter 9), in African History Before 1885, Vol. 2, ed. Toyin Falola (Durham: Carolina Academic Press, 2000).

Torres, Arlene and Norman E. Whitten, Jr., eds., Blackness in Latin America and the Caribbean: Social Dynamics and Cultural Transformations, 2 vol s. (Bloomington: Indiana University Press, 1998).

Trend, J. B. Bolivar and the Independence of Spanish America (London: Hodder and Stoughton for English Universities Press, 1946).

Uslar Pietri, Arturo. El país necesita inmigración (Caracas: Boletín de la Cámara de Comercio de Caracas, February 1937).

Vaissière, Pierre de. Saint-Domingue: La Société, 1629-1789 (Paris, 1909).

Vansina, J an. " The K ongo ki ngdom a nd i ts ne ighbors" ( Chapter 19), i n Africa from the Sixteenth to the Eighteenth Century, UNESCO General History of Africa, Vol. 5, ed. A. Ogot (London: Heinemann, 1992).

Verger, Pierre. Notes sur le Culte des Orisa et Voudun à l'Ancienne Cote des Esclaves en Afrique (Dakar: Institut Français d'Afrique Noire, 1957).

Washington, Teresa N. Our Mothers, Our Powers, Our Texts: Manifestations of Àjé in Africana Literature (Bloomington: Indiana University Press, 2005).

Williams, Raymond. Marxism and Literature (Oxford: Oxford University Press, 1977).

Yamarte Ocando, Gustavo. Historia del Zulia (Caracas: Editorial Arte, 1986).

Zamora, H ., e t. a 1. Estudios Sociales (Caracas: Departamento d e P roducción de C olegial Bolivariana, C.A., 1998). 


\section{Other Books}

Chiossone, T ulio. Diccionario Toponímico de Venezuela (Caracas: Monte A vila E ditores, 1992).

Diccionario de la Historia Venezuela, $2^{\text {nd }}$ ed., Marianela Ponce, s.v. "Chourio, Juan de Iturbide," Manuel Rodríguez Campos, editor (Caracas: Fundación Polar, 1997).

Hernández, Luis Guillermo and J esús A ngél P arra. Diccionario General del Zulia (Caracas: Editorial Arte, 1999).

Martin, Phyllis M. Historical Dictionary of Angola (London: Scarecrow Press, 1980).

Minihan, James. Encylclopedia of the Stateless Nations (Westport, Connecticut: G reenwood Publishing Group, 2002).

\section{Unpublished Conference and Seminar Papers}

Cohen, J eremy. " Smuggling i n E ighteenth C entury V enezuela: T he R ole of the Práctico," paper pr esented t o t he $27-29 \mathrm{M}$ arch $2003 \mathrm{~m}$ eeting o $\mathrm{ft}$ he Latin American $\mathrm{S}$ tudies Association at Dallas, Texas.

Skinner, Elliot and Franz Boas. "Transformation and Resiliency in A frica," paper to Columbia University anthropology conference, 12-13 October 1977, at Washington, DC.

\section{$\underline{\text { Journal Articles }}$}

Aguerrevere S., Juan José, ed., Fuerzas Armadas de Venezuela: Organo del Ministerio de la Defensa 259 (October-December 1973): 2-37. T his military journal contains numerous and anonymously written articles related to the life of General José Antonio Páez.

Araque de Silva, Belis. “Calendario Folklórico.”Revista Bigott 16:42 (March-June 1997): 6263.

Balza S antiago, Y sabel and J uvenal R angel. "Mucuchíes honra a San Bentio de Palermo." Revista Bigott 42 (March-June 1997): 73-91.

Baugh, D aniel A . “G reat B ritain's ' Blue W ater' P olicy, 1 689-1815.” International History Review 10 (1988), 33-58.

Borges, Adolfo, et al. "Pancreatic to xicity in mic e e licited b y Tityus zulianus and Tityus discrepans scorpion venoms.” Investigación Clínica 45:3 (2004): 269-276. 
Bracho Reyes, José Gregorio. "El culto de San Benito en el Sur del Lago de Maracaibo: Una propuesta de acercamiento desde la antropología de la música." Boletín americanista 47 (1997-Annual): 45-75.

Cierbide M artinena, $\mathrm{R}$ icardo. "La Compañía Guipuzcoana de Caracas y los vascos en Venezuela durante el siglo XVIII." Revista Internacional de Estudios Vascos 42:1 (1997): 63-75.

Dowty, Rachel. "Review of James H. Sweet, Recreating Africa: Culture, Kinship, and Religion in the African-Portuguese World." Journal of World History 16:3 (September 2005): 375-377.

Enrique, José and G aviria Lievano. "El archipelago de Los Monjes y las relaciones diplomáticas con Venezuela." Revista Credencial Historia 124 (April 2000): 9-15.

Guss, David M. "The Selling of S an Juan: The Performance of History in an A fro-Venezuelan Community." American Ethnologist 20:3 (August 1993): 451-473.

Heintze, B eatrix. “ The Extraordinary $\mathrm{J}$ ourney of $\mathrm{t}$ he $\mathrm{J}$ aga $\mathrm{t}$ hrough $\mathrm{t}$ he $\mathrm{C}$ enturies: $\mathrm{C}$ ritical Approaches to Precolonial Angolan Historical Sources." History in Africa 34 (2007): 67101.

Mattos, Hebe. "Black Troops and Hierarchies of Color in the Portuguese Atlantic World: The Case of Enrique Dias and His Black Regiment." Luso-Brazilian Review 45:1 (2008): 629.

Miller, J oseph C . "The Imbangala and the $\mathrm{C}$ hronology of $\mathrm{E}$ arly $\mathrm{C}$ entral A frican $\mathrm{H}$ istory." Journal of African History XIII:4 (1972), 549-574.

Miquelon, D ale. "Envisioning t he F rench E mpire: U trecht, 1711 -1713." French Historical Studies 24:4 (Fall 2001): 653-677.

Nishida, Mieko. "Review of Beyond Black and Red, by Matthew Restall." American Historical Review 114:5 (October 2006): 1228-1229.

Pérez, B erta E . " The J ourney t o Freedom: M aroon Forebears i n Southern V enezuela." Ethnohistory 47:3-4 (Summer-Fall 2000): 611-634.

Placido, Barbara. “An Analysis of Spirit Possession in the Venezuelan Cult of María Lionza." Journal of the Royal Anthropological Institute 7:2 (June 2001): 207-224.

Reinhardt, Thomas. "200 Years of Forgetting: Hushing up the Haitian Revolution." Journal of Black Studies 35:4 (March 2005): 246-261.

Restall, $\mathrm{M}$ atthew. "Black $\mathrm{C}$ onquistadors: A rmed A fricans in $\mathrm{E}$ arly $\mathrm{S}$ panish A merica," The Americas (October 2000): 171-205. 
Schwartz, Stuart B. "Brazil: Ironies of the Colonial Past." Hispanic American Historical Review 80:4 (2000): 681-694.

Sachs, I gnacy. «L'Image du noir dans l'art européen,» Annales, économies, civilisations, sociétés 4 (May-June 1969): 883-893.

Teacher in Abeokuta (Yoruba) as told to Crazzolara, J. P. "T he A frican Explains Witchcraft." Journal of the International African Institute 8:4 (October 1935): 504-509.

Vansina, Jan. “On Ravenstein's Edition of Battell's Adventures in Angola and Loango." History in Africa 34 (2007): 321-347.

Woodson, Carter G. "Notes on the Bakongo." Journal of Negro History 30:4 (1945): 421-431.

\section{Monograph}

Hamilton, Ruth Simms. "Toward a Paradigm for African Diaspora Studies," in Monograph No. 1: Creating a Paradigm and Research Agenda for Comparative Studies of the Worldwide Dispersion of African Peoples (East Lansing, Michigan: A frican D iaspora R esearch Project, Michigan State University, 2007).

\section{Newspaper Articles}

Alvarez, Lizette. "After Y ears of S ecrecy, S anteria i s S uddenly M uch M ore P opular, and Public,” New York Times, 27 January 1997.

Carrillo, María A lejandra. "En la tierra de los hijos de Ajé," Panorama (Maracaibo), $16 \mathrm{~J}$ une 2002.

Chumaceiro, Luis. “La venganza de la reina,” El Nacional (Caracas), 9 June 2004.

Cooper, Carolyn. "Haiti- The Price of Freedom," Jamaica Daily Gleaner (Kingston), 17 January 2010.

Garnica, Hercilia. “Humedad y corrosión debilitaron estructura de María Lionza.” El Nacional (Caracas), 7 June 2004.

Rohter, Larry. "O ther Voyages in the Shadow of Lévi-Strauss," New York Times, 5 November 2009.

“Toussaint L'Ouverture and the Haitian Revolution," Workers Vanguard (New York), Nos. 446 and 447, 12 and 26 February 1988, respectively.

"Worst Indians i n A merica: V enezuela T hinks of E xterminating the Motilones, $\mathrm{R}$ oot a nd Branch,” New York Times, 13 March 1894. 


\section{$\underline{\text { Pamphlets }}$}

Crespo, Luis Alberto. Venezuela: Tierra Mágica (Caracas: Corpoven- affiliate of PDVSA, the state-owned oil concern), pamphlet, undated (ISBN 980-259-525-V).

Fundación Banco $\mathrm{M}$ ercantil a nd $\mathrm{C}$ ANTV, $\mathrm{t}$ he $\mathrm{V}$ enezuelan na tional $\mathrm{t}$ elecommunications corporation. Rostros y personajes de Venezuela, Fascículo 2, Crear la República (newspaper supplement 2002).

Haggerty, Richard A., ed. Venezuela: A Country Study (Washington, DC: D epartment of the Army Pamphlet 550-71, $4^{\text {th }}$ ed., 1993).

McKinnon, Jesse. The Black Population of the United States: March 2002 (Washington, DC: United States Census Bureau, Current Population Reports, Series P20-541, April 2003).

Symbols of Basque Unity (fact sheet), undated, Basque Museum and Cultural Center, 611 Grove

\section{Internet}

Street, Boise, ID 83702, received on 13 July 2009.

African Diaspora Archaeology Network Newsletter (December 2 008), on -line onl y, http://www.diaspora.uiuc.edu/news1208/news1208-33.pdf, (7 June 2010).

Afro-Zulian preserves black identity symbolized in Chimbánguele drums and gaita, http://www.vheadline.com/printer_news.asp?id=21761, (27 June 2004).

Alcaldia Rosario de Períja: Historia: Su fundador, (Rosario City Administration, information on the city's founder, Juan de Chourio), http://alcaldiarosariodeperija.com.ve, (27 April 2009).

Bari Language, http://www.native-languages.org/bari.htm, (15 December 2009).

Basque genealogy, http://hal.archives-ouvertes.fr/docs/00/33/98/60/PDF/Patronymes_d_origine_ basque.pdf, (9 March 2009).

Catholic Hierarchy in Colonial Venezuela, http://www.catholic-hierarchy.org/bishop/bmartim.html, (12 June 2010).

Cattle, (9 May 2010), on-line daily news, http://perija.com/?p=2040, (4 August 2010).

Central Government of the Netherlands Antilles, (General i nformation a nd 1 ocation of $\mathrm{t}$ he Caribbean island group), http://www.gov.an, (17 August 2009).

Cuadernos Digitales: Publicación Eléctrica en Historia, Archivística y Estudios Sociales 15 (October 2001) , La U niversidad de C osta R ica, http://historia.fcs.ucr.ac.cr/cuadernos/c15his.htm, (28 January 2010).

Demystifying Africa's Absence in Venezuelan History and Culture (15 J anuary 2004), on -line only, www.venezuelanalysis.com, (19 August 2004). 
Ethnic groups, http://www.cia.gov/cia/publications/factbook/geos/ve.html, (27 September 2002).

Geographic Coordinates of Perijá as Measured from the Plaza Bolívar, www.elbrollo.com, (27 April 2009).

Gobernación del Estado Zulia, ( Guaged di stance be tween R osario a nd c ity of M aracaibo), www.gobernaciondelzulia.gov.ve, (12 June 2010).

Government of Navarra, (Background information on the status of Basque lands in relation to Spain and neighboring countries), http://www.navarra.es/home_en/Navarra/Asi+es+Navarra/ Autogobierno/El+Reino+de+Navarra.htm, (27 April 2009).

Historia del Municipio Rosario de Perijá, http://tuzulia.com, (27 April 2009).

Historia del Municipio Rosario de Perijá, http://www.perija.com/elcorreodelasierra/html/rosario deperija.htm, (27 August 2009).

Irissarry, (Location of Iturbide $\mathrm{f}$ amily $\mathrm{l}$ ands $\mathrm{i} \mathrm{n} \mathrm{F}$ rench $\mathrm{B}$ asque $\mathrm{t}$ erritory), http://maps.google.com/maps, (16 August 2009).

José Antonio Páez, http://www.auyantepui.com/historia/paez.html, (5 October 2002).

José Leonardo Chirino, http://www.kalipedia.com/kalipediamedia/historia/media/200808/01/his venezuela/20080801klphishve_2_Ies_SCO.jpg (21 November 2010).

Magia Brasiliana, http://www.carlos-luconi.com/in/Conde_Luconi_Brazilian_Magic.htm, (13 March 2010).

Maracaibo: De Botica Nueva a Cobeca, 100 años de historia, http://www.lamaracucharadio. com/NOTICIAS/BoticaNueva.htm, (4 August 2010).

Minorities at Risk: Assessment for Blacks in Colombia, http://www.cidcm.umd.edu/mar/assess ment.asp?groupId=10001, (21 November 2010).

Official Tourism Website of Aruba, (General i nformation a bout the i sland, i ts hi story a nd government), http://www.aruba.com/ExploretheIsland/IslandFacts/history.aspx $\quad(17 \mathrm{~A}$ ugust 2009).

Pirates of the Caribbean, (ships ut ilized), piratesofthecaribbeansea.com/ships2.html, ( $9 \mathrm{M}$ arch 2009).

Pirates, the Scourge of the Spanish Main, piratesofthecaribbeansea.com/ships2.html, (17 August 2009). 
Statia State Tourist Office, ( Geographic c oordinates a nd 1 ocation of $\mathrm{S}$ tatia i sland i $\mathrm{n} \mathrm{t}$ he Caribbean), http://www.statiatourism.com/map.html, (17 August 2009).

Traductions Basques de la "Philothée," (Religious background of some of the Chourio family), http://hedatuz.euskomedia.org/167/1/16056064.pdf (27 April 2009).

Villa del Rosario, http:/www.pueblosdevenezuela.com/Zulia/ZU-VillaDelRosario.htm (4 August 2010). 